\title{
Hydrogeology and Shallow Groundwater Quality in the Tidal Anacostia River Watershed, Washington, D.C.
}

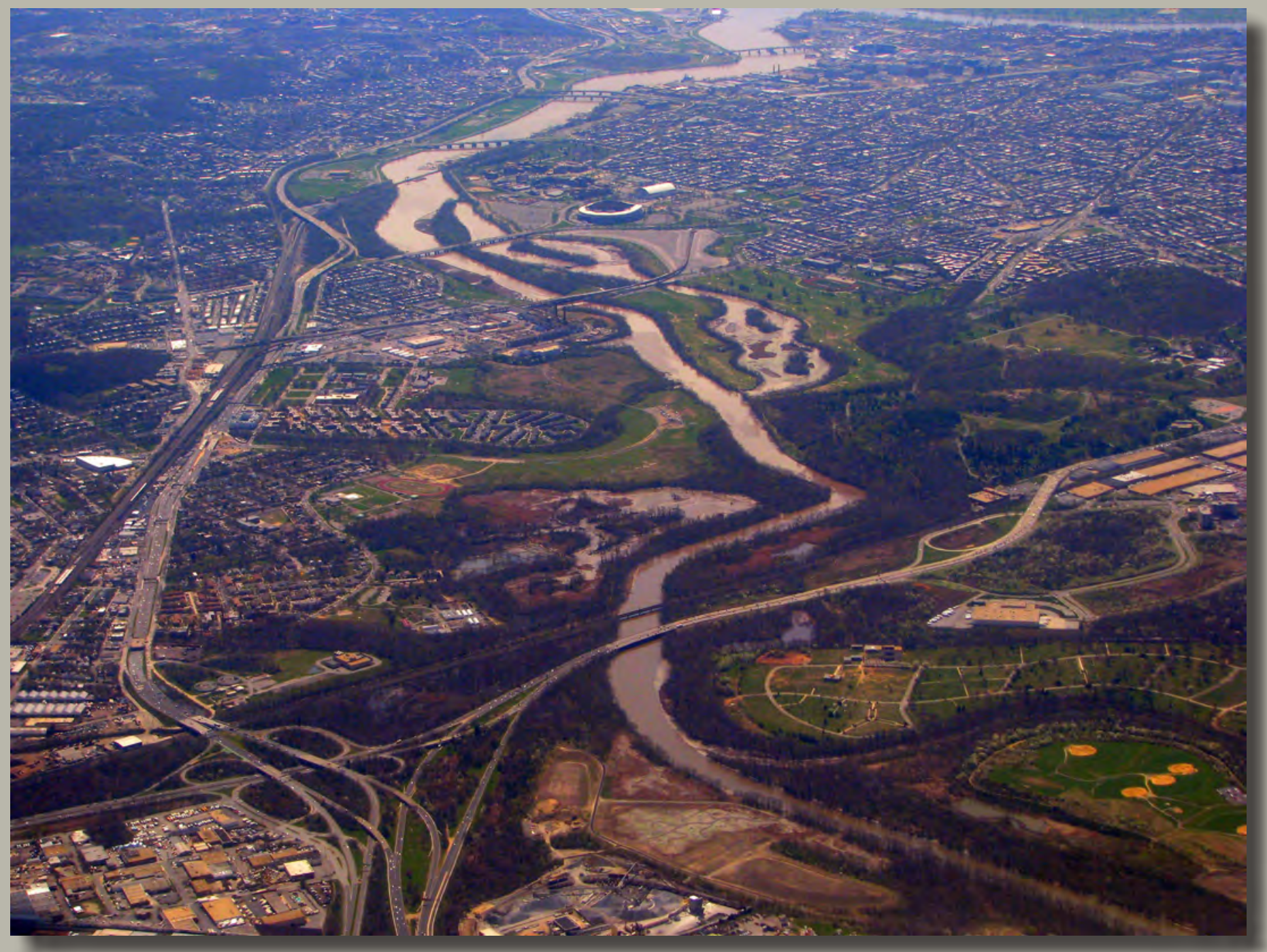

Scientific Investigations Report 2019-5128

U.S. Department of the Interior

U.S. Geological Survey 
Cover: Aerial view, looking southwest, of tidal Anacostia River, Washington, D.C. Photograph by Daniel Macy, April 5, 2009. 


\section{Hydrogeology and Shallow Groundwater Quality in the Tidal Anacostia River Watershed, Washington, D.C.}

By Scott W. Ator, Judith M. Denver, and Cheryl A. Dieter

Scientific Investigations Report 2019-5128 


\section{U.S. Department of the Interior DAVID BERNHARDT, Secretary}

\section{U.S. Geological Survey James F. Reilly II, Director}

U.S. Geological Survey, Reston, Virginia: 2020

For more information on the USGS - the Federal source for science about the Earth, its natural and living resources, natural hazards, and the environment-visit https://www.usgs.gov or call 1-888-ASK-USGS.

For an overview of USGS information products, including maps, imagery, and publications, visit https://store.usgs.gov.

Any use of trade, firm, or product names is for descriptive purposes only and does not imply endorsement by the U.S. Government.

Although this information product, for the most part, is in the public domain, it also may contain copyrighted materials as noted in the text. Permission to reproduce copyrighted items must be secured from the copyright owner.

Suggested citation:

Ator, S.W., Denver, J.M., and Dieter, C.A., 2020, Hydrogeology and shallow groundwater quality in the tidal Anacostia River watershed, Washington, D.C.: U.S. Geological Survey Scientific Investigations Report 2019-5128, 93 p., https://doi.org/10.3133/sir20195128. 


\section{Acknowledgments}

This work was conducted in cooperation with the District Department of Energy \& Environment (DOEE), Water Quality Division. The authors thank Diane Douglas and other staff at DOEE for their support of the study. The authors would also like to thank the National Park Service and the Washington, D.C. Department of Parks and Recreation for their cooperation and permission to install wells and monitor groundwater for this study. The authors thank David Drummond of the Maryland Geological Survey, Irene Abbene (USGS), and Jeff Raffensperger (USGS) for thoughtful and helpful technical comments. Finally, the authors thank Kenneth Warren (USGS), Tim Auer (formerly of USGS), and Kimberly Engelking (USGS) for work on illustrations, tables, and report layout, and Valerie Gaine (USGS) for editorial review and assistance with publication of this report. 


\section{Contents}

Abstract

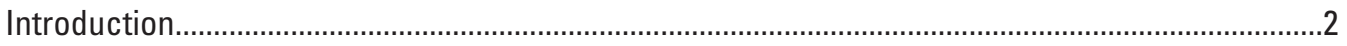

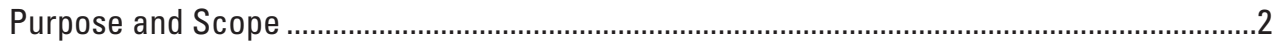

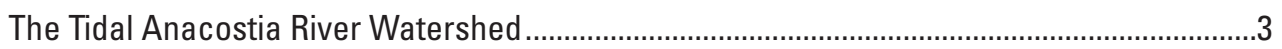

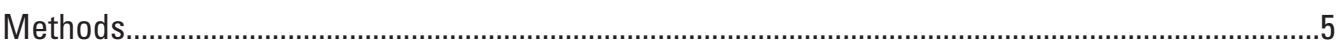

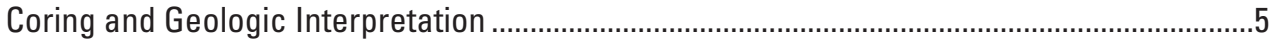

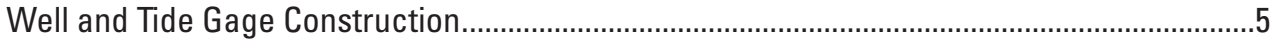

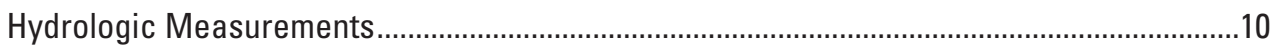

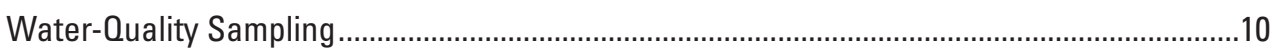

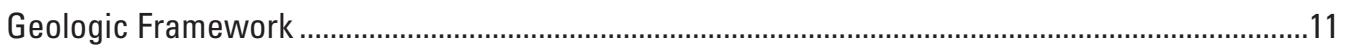

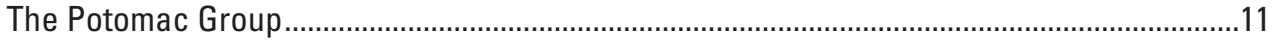

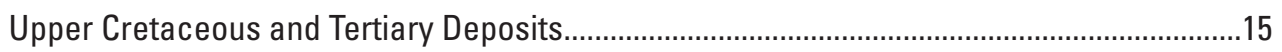

Upper Tertiary and Younger Deposits ..............................................................................15

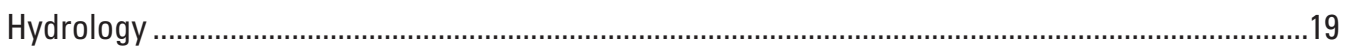

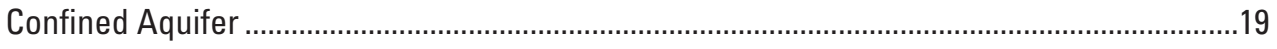

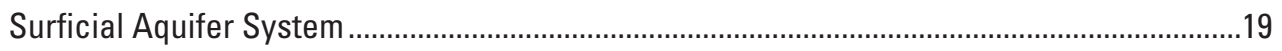

Groundwater-Surface-Water Interaction......................................................................22

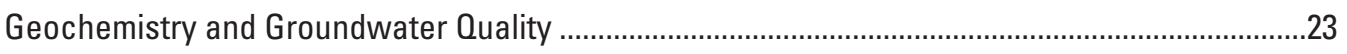

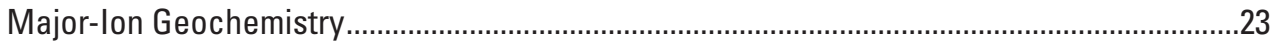

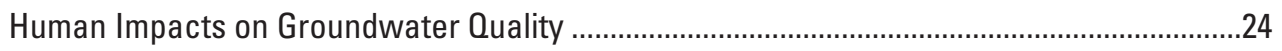

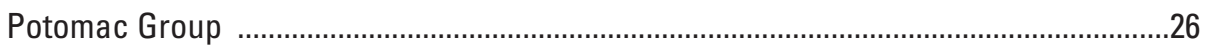

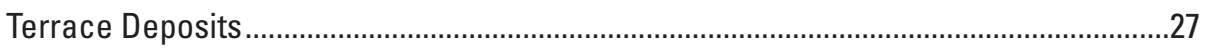

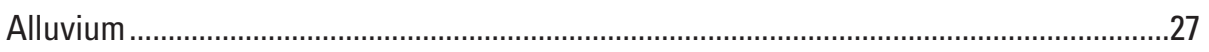

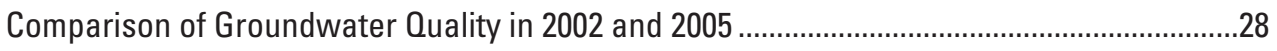

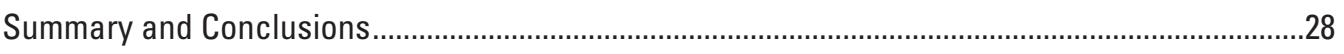

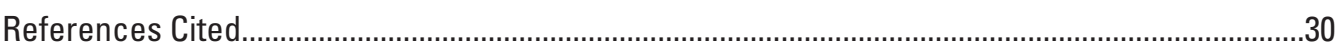

Appendix 1. Selected Lithologic Core Descriptions in and near the Anacostia

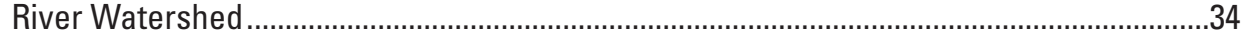

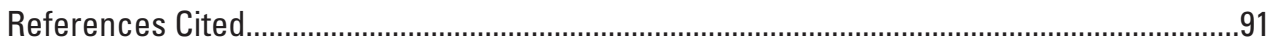

Appendix 2. Continuous Groundwater-Level and Temperature Measurements at Sites We Bb 3, We Bb 4, We Cb 5, We Cb 6, We Cb 8, and We Cb 12 ..............................92

Appendix 3. Instantaneous Groundwater-Level Measurements Collected at Selected Sites in the Anacostia River Watershed, 2002-11 ...................... Available Online Appendix 4. Tide Levels at USGS Station 01651750, Anacostia River Aquatic Gardens at Washington, D.C., 2004-07

Available Online

Appendix 5. South Capitol Street Geotechnical Report, MACTEC Engineering and Consulting, Inc., 2005 (reproduced with permission) .

Available Online 


\section{Figures}

1. Map showing location of the tidal Anacostia River watershed within Washington, D.C... .4

2. Map showing location of monitoring wells, selected cores, and historical streams in the tidal Anacostia River watershed study area, Washington, D.C.

3. Map showing generalized geology of the tidal Anacostia River watershed, selected lithologic description locations, and cross-section locations, Washington, D.C..

$4 A-B$. Generalized geologic cross sections $A-A^{\prime}$ and $B-B^{\prime}$, showing hypothetical groundwater-flow directions in the tidal Anacostia River watershed, Washington, D.C......

4C. Generalized geologic cross section $C-C^{\prime}$ showing hypothetical groundwaterflow directions in the tidal Anacostia River watershed, Washington, D.C.

$4 D$. Generalized geologic cross section $D-D^{\prime}$ through the Coastal Plain sediments in the tidal Anacostia River watershed, Washington, D.C.

5. Distribution of the clay-dominated lithofacies of the Potomac Group within the tidal Anacostia River watershed, Washington, D.C.

6. Graph showing groundwater temperature over time measured in selected shallow wells near the Anacostia River

7. Graphs showing groundwater levels over time at the same location but different depths within the terrace deposits.

8. Map showing estimated orientation of the regional water table, and generalized groundwater-flow directions in the surficial aquifer, tidal Anacostia River watershed, Washington, D.C., and vicinity...

9. Graph showing tidal fluctuations in water levels in the Anacostia River and in nearby shallow groundwater wells WE Bb 3 and WE Bb 4, July 2004

10. Trilinear diagram showing general water chemistry by geologic unit for groundwater samples collected from the Anacostia River watershed in Washington, D.C., September-December 2005.

\section{Tables}

1. Summary of monitoring locations and associated instrumentation in the tidal Anacostia River watershed, Washington, D.C.

2. Summary of selected lithologic description locations in and near the tidal Anacostia River watershed, Washington, D.C

3. Summary and results of aquifer slug tests on selected wells

4. Summary of Coastal Plain geologic and hydrogeologic units in the tidal Anacostia River watershed, Washington, D.C. and surrounding area.

5. Summary of selected water-quality constituents in groundwater in different geologic settings in the Anacostia River watershed within Washington, D.C., 2005......25

6. Distribution of organic compounds by type in groundwater samples from different geologic settings in the Anacostia River watershed within Washington, D.C., 2005.

7. Summary of organic compounds detected in groundwater samples from 17 wells in the Anacostia River watershed within Washington, D.C., SeptemberDecember 2005. 


\section{Conversion Factors and Datums}

\begin{tabular}{|c|c|c|}
\hline Multiply & By & To obtain \\
\hline \multicolumn{3}{|c|}{ Length } \\
\hline inch (in.) & 2.54 & centimeter $(\mathrm{cm})$ \\
\hline foot $(\mathrm{ft})$ & 0.3048 & meter $(\mathrm{m})$ \\
\hline mile (mi) & 1.609 & kilometer $(\mathrm{km})$ \\
\hline \multicolumn{3}{|c|}{ Area } \\
\hline acre & 0.004047 & square kilometer $\left(\mathrm{km}^{2}\right)$ \\
\hline square mile $\left(\mathrm{mi}^{2}\right)$ & 2.590 & square kilometer $\left(\mathrm{km}^{2}\right)$ \\
\hline \multicolumn{3}{|c|}{ Volume } \\
\hline gallon (gal) & 3.785 & liter $(\mathrm{L})$ \\
\hline \multicolumn{3}{|c|}{ Flow rate } \\
\hline gallon per minute (gal/min) & 0.06309 & liter per second $(\mathrm{L} / \mathrm{s})$ \\
\hline cubic foot per second $\left(\mathrm{ft}^{3} / \mathrm{s}\right)$ & 0.02832 & cubic meter per second $\left(\mathrm{m}^{3} / \mathrm{s}\right)$ \\
\hline million gallons per day (Mgal/d) & 0.04381 & cubic meter per second $\left(\mathrm{m}^{3} / \mathrm{s}\right)$ \\
\hline \multicolumn{3}{|c|}{ Mass } \\
\hline pound, avoirdupois (lb) & 0.4536 & kilogram (kg) \\
\hline \multicolumn{3}{|c|}{ Hydraulic conductivity } \\
\hline foot per day (ft/d) & 0.3048 & meter per day $(\mathrm{m} / \mathrm{d})$ \\
\hline \multicolumn{3}{|c|}{ Transmissivity* $^{*}$} \\
\hline foot squared per day $\left(\mathrm{ft}^{2} / \mathrm{d}\right)$ & 0.09290 & meter squared per day $\left(\mathrm{m}^{2} / \mathrm{d}\right)$ \\
\hline
\end{tabular}

Temperature in degrees Celsius $\left({ }^{\circ} \mathrm{C}\right)$ may be converted to degrees Fahrenheit $\left({ }^{\circ} \mathrm{F}\right)$ as follows:

$$
{ }^{\circ} \mathrm{F}=\left(1.8 \times{ }^{\circ} \mathrm{C}\right)+32
$$

Vertical coordinate information is referenced to the North American Vertical Datum of 1988 (NAVD 88).

Horizontal coordinate information is referenced to the North American Datum of 1983 (NAD 83).

Altitude, as used in this report, refers to distance above the vertical datum.

*Transmissivity: The standard unit for transmissivity is cubic foot per day per square foot times foot of aquifer thickness ([ft $\left.\left.\mathrm{ft}^{3} / \mathrm{d}\right] / \mathrm{ft}^{2}\right) \mathrm{ft}$. In this report, the mathematically reduced form, foot squared per day $\left(\mathrm{ft}^{2} / \mathrm{d}\right)$, is used for convenience.

Specific conductance is given in microsiemens per centimeter at 25 degrees Celsius $(\mu \mathrm{S} / \mathrm{cm}$ at $\left.25^{\circ} \mathrm{C}\right)$.

Concentrations of chemical constituents in water are given either in milligrams per liter (mg/L) or micrograms per liter $(\mu \mathrm{g} / \mathrm{L})$. 


\section{Abbreviations}

$\begin{array}{ll}\text { DOEE } & \text { District Department of Energy \& Environment } \\ \text { MCL } & \text { maximum contaminant level } \\ \text { msl } & \text { mean sea level } \\ \text { PAH } & \text { polycyclic aromatic hydrocarbon } \\ \text { PCB } & \text { polychlorinated biphenyl } \\ \text { PVC } & \text { polyvinyl chloride } \\ \text { RBC } & \text { risk-based concentration } \\ \text { SVOC } & \text { semi-volatile organic compound } \\ \text { USGS } & \text { U.S. Geological Survey } \\ \text { VOC } & \text { volatile organic compound }\end{array}$




\title{
Hydrogeology and Shallow Groundwater Quality in the Tidal Anacostia River Watershed, Washington, D.C.
}

\author{
By Scott W. Ator, Judith M. Denver, and Cheryl A. Dieter
}

\section{Abstract}

Groundwater hydrology and geochemistry within the tidal Anacostia River watershed of Washington, D.C. are related to natural and human influences. The U.S. Geological Survey, in cooperation with the District Department of Energy \& Environment, began investigating the hydrogeology and groundwater quality of the watershed in 2002. Lithologic coring, groundwater-level and tidal monitoring, and water-quality sampling have been conducted to improve understanding of the groundwater-flow system, geochemistry, water quality, and the likely interaction between groundwater and the tidal Anacostia River. The flow and interaction of shallow groundwater with the tidal Anacostia River and other area streams are affected by diversions, pumping, land reclamation, and other human activities in this highly urbanized watershed.

The tidal Anacostia River watershed is underlain by a wedge of unconsolidated sediments that is part of the Atlantic Coastal Plain Physiographic Province. These sediments form a system of confined and unconfined aquifers. The coarse sediments of the Potomac Group sand-dominated lithofacies form the Patuxent aquifer. The Patuxent aquifer crops out and subcrops in the northwestern part of the study area, but is confined to the southeast by the overlying Potomac Group clay-dominated lithofacies. Overlying the Potomac Group is a series of interbedded sands and clays that form an unconfined surficial aquifer system. Regional correlation in the unconfined surficial aquifer system is complicated by local heterogeneity in aquifer sediments. Local perched and semi-confined conditions occur in some areas.

Recharge of the confined Patuxent aquifer occurs primarily in the outcrop and subcrop area, although some recharge may also occur through overlying confining units.
Recharge to the unconfined surficial aquifer system occurs through infiltration of precipitation and possible artificial recharge from structures such as underground water or sewer pipes. In the Patuxent aquifer, hydraulic gradients indicate downward movement in the outcrop area, whereas hydraulic heads beneath the Anacostia River are higher than land surface, indicating an upward hydraulic gradient. In the unconfined surficial aquifer system, groundwater generally flows from upland recharge areas towards discharge areas near the Anacostia River and its tributaries. Groundwater from the confined part of the Patuxent aquifer also may discharge to the Anacostia River in locations where the overlying claydominated lithofacies of the Potomac Group is absent as a result of past geologic and (or) alluvial processes.

Geochemistry and groundwater quality are affected by hydrologic conditions as well as anthropogenic influences. Local variability in groundwater quality reflects local variability in hydrogeologic conditions and sources of chemicals. Groundwater ranges from anoxic and iron- or calcium-bicarbonate type, to oxic with elevated nitrate. The occurrence and distribution of pesticides, volatile organic compounds, and other selected chemical compounds in groundwater reflect the multitude of sources common to urban areas, as well as variable hydrogeologic and geochemical conditions that affect their fate and transport in the environment. Overall, concentrations of only a few of the over 200 chemical constituents included in laboratory analyses exceeded regulatory standards or guidance values. These include tetrachloroethene and arsenic, which were each detected one time in different wells. There were also several detections of iron and manganese that exceeded regulatory standards or guidance values that are associated with reducing conditions in aquifer sediments. 


\section{Introduction}

A wide variety of chemical compounds are used for various purposes in urban areas including Washington, D.C. These chemical compounds include pesticides, volatile organic compounds (VOCs), fertilizers, metals, pharmaceuticals, and deicing chemicals. Although agriculture accounts for more than 75 percent of pesticide usage in the United States, more than 200 million pounds of pesticides are used annually for industrial, commercial, government, or residential (home and garden) applications (Kiely and others, 2004). VOCs are also commonly found in urban areas; commercial, industrial, or residential products containing VOCs include cosmetics, deodorants, polishes, adhesives, cleaning products, paints, solvents, and fuels (Moran and others, 2002). The District Department of Energy \& Environment (DOEE) is responsible for protecting the water resources of Washington, D.C., and understanding the occurrence or lack thereof of these compounds is essential to the management of these resources.

Urban influences on groundwater and surface-water quality have been documented in many areas over the past several decades. Koterba and others (2010) found that in Washington, D.C., the presence of pesticides in groundwater was related to land use and hydrogeologic factors, such as depth of a well, the permeability of subsurface sediment, and the chemistry of groundwater. Similarly, a survey of urban areas across the United States during 1992 to 2001 found that pesticides were detected at relatively low levels (rarely greater than 0.1 microgram per liter $(\mu \mathrm{g} / \mathrm{L})$ in more than 90 percent of stream samples and more than 50 percent of groundwater samples (Gilliom and others, 2006). Urban streams and (or) groundwater commonly contain insecticides and herbicides commonly used in urban settings (such as prometon and simazine), as well as herbicides more common in agricultural areas (such as atrazine and metolachlor) (Capel and others, 1999; Reiser, 1999; Hickman, 2004; Gilliom and others, 2006). VOCs also have been detected in groundwater in urban areas (Zogorski and others, 2006), such as Long Island, New York (Eckhardt and Stackelberg, 1995) and the suburbs of Detroit, Michigan (Thomas, 2000). They are more commonly detected in urban areas than in areas with other land uses (Zogorski and others, 2006). Nitrate (Eckhardt and Stackelberg, 1995), metals (Velinsky and others, 1994), pharmaceuticals and hormonal compounds (Kolpin and others, 2002), and salt from septic discharges or highway deicing (Thomas, 2000) also have been detected in urban streams and (or) groundwater. Because many anthropogenic compounds are used for similar applications or in similar areas, they often co-occur in mixtures of multiple compounds in streams and groundwater, rather than individually (Thomas, 2000; Squillace and others, 2002; Gilliom and others, 2006). The possible health effects of these mixtures have not been studied extensively and are largely unknown (Gilliom and others, 2006).

Groundwater provides the majority of flow in many streams, and may carry a significant load of chemical compounds to surface waters. Many anthropogenic compounds are applied directly to the land surface; others may reach the land surface or streams through atmospheric deposition, leaks, or spills. In Washington, D.C., particularly soluble and persistent compounds may become dissolved in water and carried into and through the groundwater system to discharge areas in streams, estuaries, or other receiving waters, such as the Anacostia or Potomac Rivers. The relative importance of groundwater, overland runoff, and other transport processes to particular streams is affected by hydrogeologic conditions and resulting groundwater-flow systems that develop in their watersheds. Groundwater may be particularly important in well-drained watersheds underlain by relatively permeable geologic materials, for example, but less so in areas with relatively impermeable sediments or bedrock. Groundwater contributes nutrients and pesticides to streams on the Delmarva Peninsula (Denver and others, 2004; Ator and others, 2005), including an estimated 40 percent of nitrogen loads from the Peninsula to Chesapeake Bay (Bachman and Phillips, 1996). Contributions of nutrients from groundwater have also been reported for streams in the upper Potomac River Basin (Miller and others, 1997). Groundwater flow is slow, however, and years to several decades are often required for water to move completely through a shallow aquifer from recharge areas to discharge areas (Dunkle and others, 1993; Focazio and others, 1998).

\section{Purpose and Scope}

The geology, hydrology, and groundwater quality within the heavily urbanized tidal Anacostia River watershed in Washington, D.C. are described and discussed in this report. Physical characteristics of the Coastal Plain sediments, and the occurrence, flow, and chemistry of groundwater in the area are discussed, with a particular emphasis on the uppermost surficial sediments that are most likely contributing groundwater to the Anacostia River and other local surface waters. Interpretations and conclusions are based on data collected from 2002 through 2008 as part of a cooperative study between the U.S. Geological Survey (USGS) and the DOEE, Water-Quality Division, as well as similar information from previous studies. Hydrogeologic investigations were conducted in the watershed as a first step toward (1) evaluating the hydrologic connection between the Anacostia River and adjacent shallow groundwater, (2) assessing shallow groundwater quality and possible effects on water quality in the Anacostia River, and (3) establishing a groundwater monitoring network for the District of Columbia. 


\section{The Tidal Anacostia River Watershed}

The Anacostia River is a tributary to the tidal Potomac River in central Maryland and Washington, D.C. (fig. 1). The head of tide on the Anacostia River is located upstream from the District of Columbia near Bladensburg, Maryland (Velinsky and others, 1994); the river is entirely freshwater tidal within the study area. The specific conductance of the freshwater tidal Anacostia River ranges from 300 to 500 microsiemens per centimeter $(\mu \mathrm{S} / \mathrm{cm})$, and the $\mathrm{pH}$ ranges from 6 to 8 (District Department of the Environment, 2010). In the winter, the specific conductance occasionally increases to 1,000 to $5,000 \mu \mathrm{S} / \mathrm{cm}$ as a result of road salting. The approximately 26-square-mile ( $\mathrm{mi}^{2}$ ) tidal Anacostia River watershed includes most of eastern Washington, D.C., and lies entirely within the Atlantic Coastal Plain Physiographic Province (Fenneman and Johnson, 1946). The watershed is almost exclusively (greater than 80 percent) urban, including mixed residential, commercial, and industrial areas. In addition to potential sources of anthropogenic compounds, urban development over the last 200 years has brought considerable hydrologic alteration to the watershed, including dredging of the Anacostia River, filling of tributaries and riparian areas, construction of impervious surfaces, sewers, pipelines, and tunnels, and dewatering for construction purposes (Williams, 1977; D.C. Water Resources Research Center, 1992).

Water quality and sediment chemistry in the Anacostia River reflect urban influences in the watershed. In addition to direct runoff over the land surface during and following precipitation, the river also receives direct discharge from numerous storm sewers and combined sewers, which contribute contaminants such as trace metals (Velinsky and others, 1994) and chlordane (Wade and others, 1994). Other potentially toxic materials that have been detected in Anacostia River sediment include polychlorinated biphenyls (PCBs) and polycyclic aromatic hydrocarbons (PAHs) (Behm and others, 2003). PAHs may cause tumors in brown bullheads in the river, and PCBs and chlordane have contributed to fish consumption advisories in the Anacostia River since 1987 (Behm and others, 2003). 


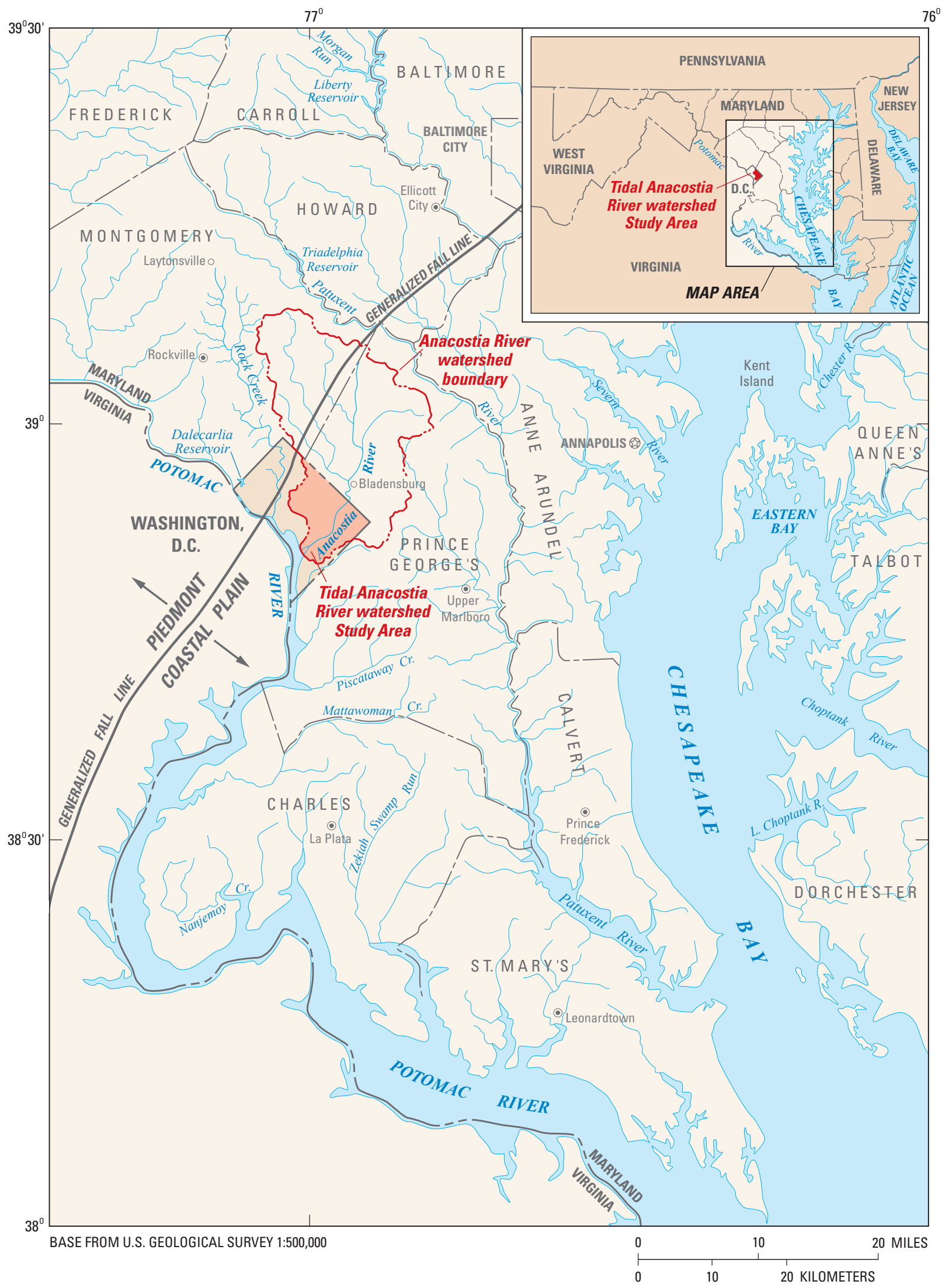

Figure 1. Location of the tidal Anacostia River watershed within Washington, D.C. (modified from Tenbus, 2003, and Anderson and others, 2002). 


\section{Methods}

Available information was compiled, and new data were collected to describe the hydrogeologic framework and shallow groundwater quality within the Coastal Plain sediments of the tidal Anacostia River watershed. The hydrogeologic framework of the Coastal Plain sediments in the area was inferred from previous interpretations and newly available borehole data. Groundwater flow and quality were similarly interpreted from results of previous studies and data collected during this study. Data on the occurrence, distribution, and chemistry of groundwater in the study area were collected to support an interpretation of groundwater quality and its potential impacts on the Anacostia River.

\section{Coring and Geologic Interpretation}

Geologic cores were collected and analyzed to supplement existing information on the Coastal Plain geologic framework in the study area (fig. 2, tables 1, 2, Appendix 1). Coring was primarily conducted to characterize relatively shallow sediments (within approximately 40 feet [ft] of land surface); these sediments are most relevant to the flow and quality of shallow groundwater that is most likely affected by anthropogenic chemicals and may be discharging to local surface waters. Shallow sediments are also particularly variable in texture and composition, and this information is therefore difficult to extrapolate over wide areas.

Shallow cores were collected within the tidal Anacostia River watershed study area in 2002, 2005, and 2008 (tables 1, 2). Coring was conducted at selected sites within and near the tidal Anacostia River in July 2002 (Miller and Klohe, 2003; Tenbus, 2003). Cores were collected along the river near the New York Avenue crossing (WE Bb 4 on fig. 2), at Kenilworth Aquatic Gardens (WE Cb 6 on fig. 2), and in Anacostia Park (WE Ca 29 on fig. 2). Additional cores were collected in the river on a tidal flat about 1,700 ft north of Benning Road (WE Ca 30 on fig. 2), and in Beaverdam Creek, about $150 \mathrm{ft}$ above its confluence with the Anacostia River (WE Cb 7 on fig. 2). Cores were collected using a vibracore drill rig mounted on a truck or (for the offshore sites) a hovercraft. Coring was conducted to refusal (typically about 30 to $40 \mathrm{ft}$ below land surface), and cores were collected in 5-ft increments (Miller and Klohe, 2003; Tenbus, 2003). Additional cores were collected within the watershed at 13 locations in July and August 2005 (AC Aa 2, AC Ab 3, WE Ba 9, WE Ba 10, WE Ca 33, WE Ca 34, WE Ca 38, WE Cb 11, WE Cb 12, WE Cc 3, WE Bc 8, WW Bc 9, and WW Cc 37 on fig. 2) and at two locations (AC Aa 6 and AC Aa 7 on fig. 2) in May 2008 using a truck-mounted hollow-stem auger or Geoprobe. In cooperation with the DOEE and the D.C. Clean Rivers
Project, a borehole was extended $10 \mathrm{ft}$ into competent bedrock in 2009 (AX Ac 2, table 2, Appendix 1) to determine the depth to bedrock.

Geologic cores were reviewed and analyzed to document and interpret the nature and variability of near-surface sediments in the study area, and to support interpretation of shallow groundwater flow and quality. All cores collected for this project were briefly described onsite during the drilling process, and more thoroughly described (particularly for color and grain size) later at the USGS Water Science Center in Baltimore, Maryland (Tenbus, 2003) (Appendix 1). Additional cores collected primarily along the Anacostia River in 2007 by the District of Columbia Water and Sewer Authority were also reviewed and interpreted by USGS. Because of the variable nature of shallow sediments (land surface to approximately $40 \mathrm{ft}$ below land surface) in the study area, shallow cores were used primarily to interpret local conditions, and were not correlated throughout the study area (Tenbus, 2003), but descriptions are provided in Appendix 1. Deeper cores (greater than $40 \mathrm{ft}$ deep) were correlated throughout the study area. Sediment from selected cores was also analyzed for selected chemical constituents, including nutrients, metals, pesticides, PCBs, and VOCs (Miller and Klohe, 2003).

Cross-sectional data from various sources were also incorporated into the geologic interpretations. Cross sections are from various sources primarily located at existing bridge locations. Cross-sectional data from the South Capitol Street Bridge geotechnical report (Appendix 5, MACTEC Engineering and Consulting, Inc., 2005), the $11^{\text {th }}$ Street Bridge cross section, and D.C. Metro crossings were incorporated into the interpretation.

\section{Well and Tide Gage Construction}

A network of 27 shallow monitoring wells and 1 tidal gage was established to support hydrologic measurements and water-quality sampling (table 1). Ten existing wells (AC Aa 1, AX Ac 1, WE Ca 31, WE Ca 32, WE Ca 35, WE Ca 36, WE $\mathrm{Ca} 37, \mathrm{WE} \mathrm{Cb} 8$, WE Cb 9, and WE Cb 10) were included in the monitoring network (fig. 2, table 1); these wells were installed by various other groups, but were included as part of the monitoring network on the basis of location, geologic setting, access, and available well-construction and other ancillary information. Seventeen additional wells (AC Aa 2, AC Aa 6, AC Aa 7, WE Ba 9, WE Ba 10, WE Bb 3, WE $\mathrm{Bb} 4$, WE Ca 29, WE Ca 33, WE Ca 34, WE Cb 5, WE Cb 6, WE Cb 11, WE Cb 12, WE Cc 3, WW Bc 8, and WW Bc 9) were constructed in boreholes resulting from geologic coring to supplement information available at the 10 existing wells listed above. In addition, a tide gage (USGS station number 01651750) was constructed on the Anacostia River. 


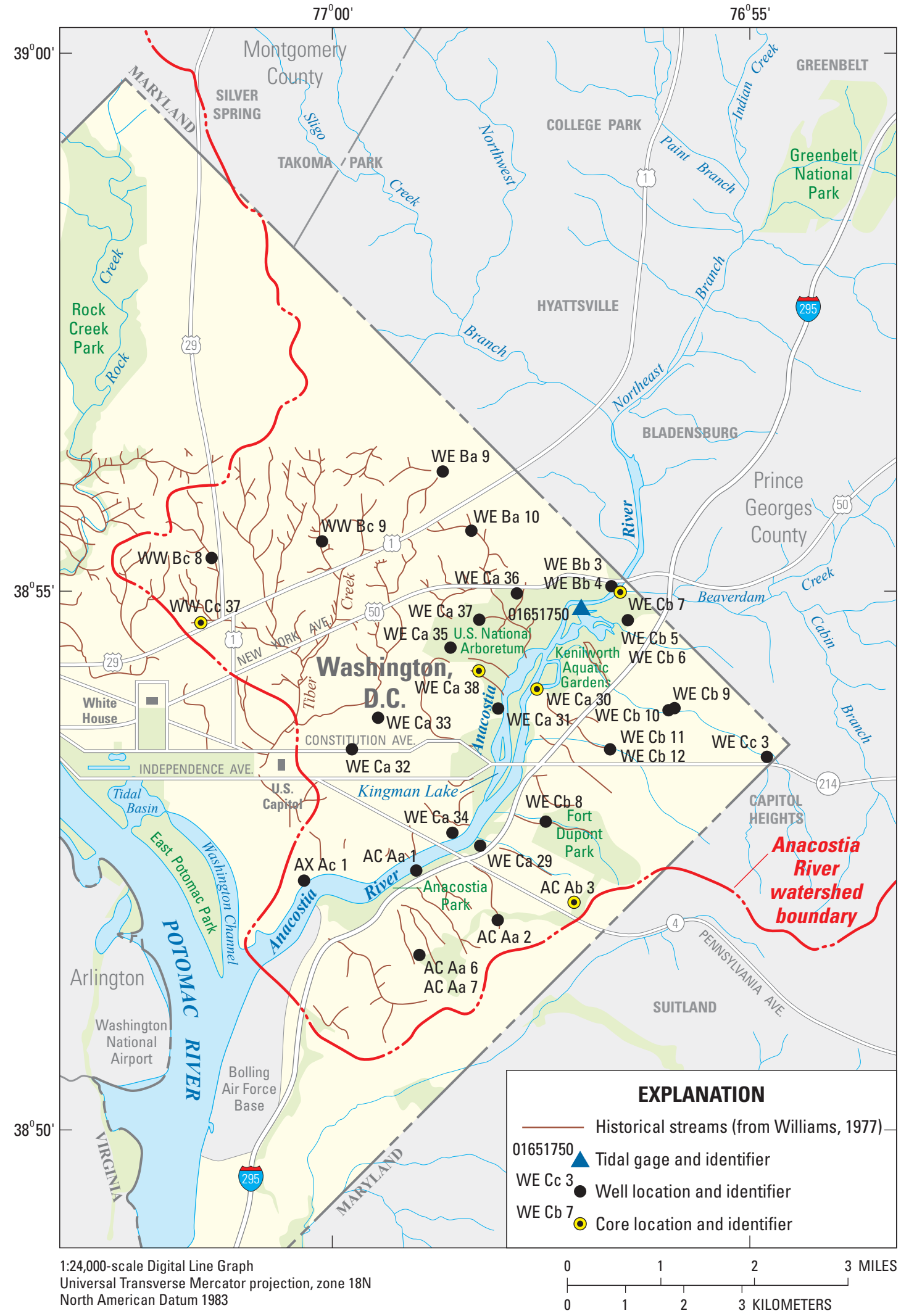

Figure 2. Location of monitoring wells, selected cores, and historical streams in the tidal Anacostia River watershed study area, Washington, D.C. 
Table 1. Summary of monitoring locations and associated instrumentation in the tidal Anacostia River watershed, Washington, D.C.

[USGS, U.S. Geological Survey; DDOE, District Department of Energy and Environment; ft bls, feet below land surface; GE, geologic or lithologic core; WL, water level; AT, aquifer test; QW, water quality; $\mathrm{X}$, data are available; Co, continuous data are available; $\mathrm{P}$, periodic data are available]

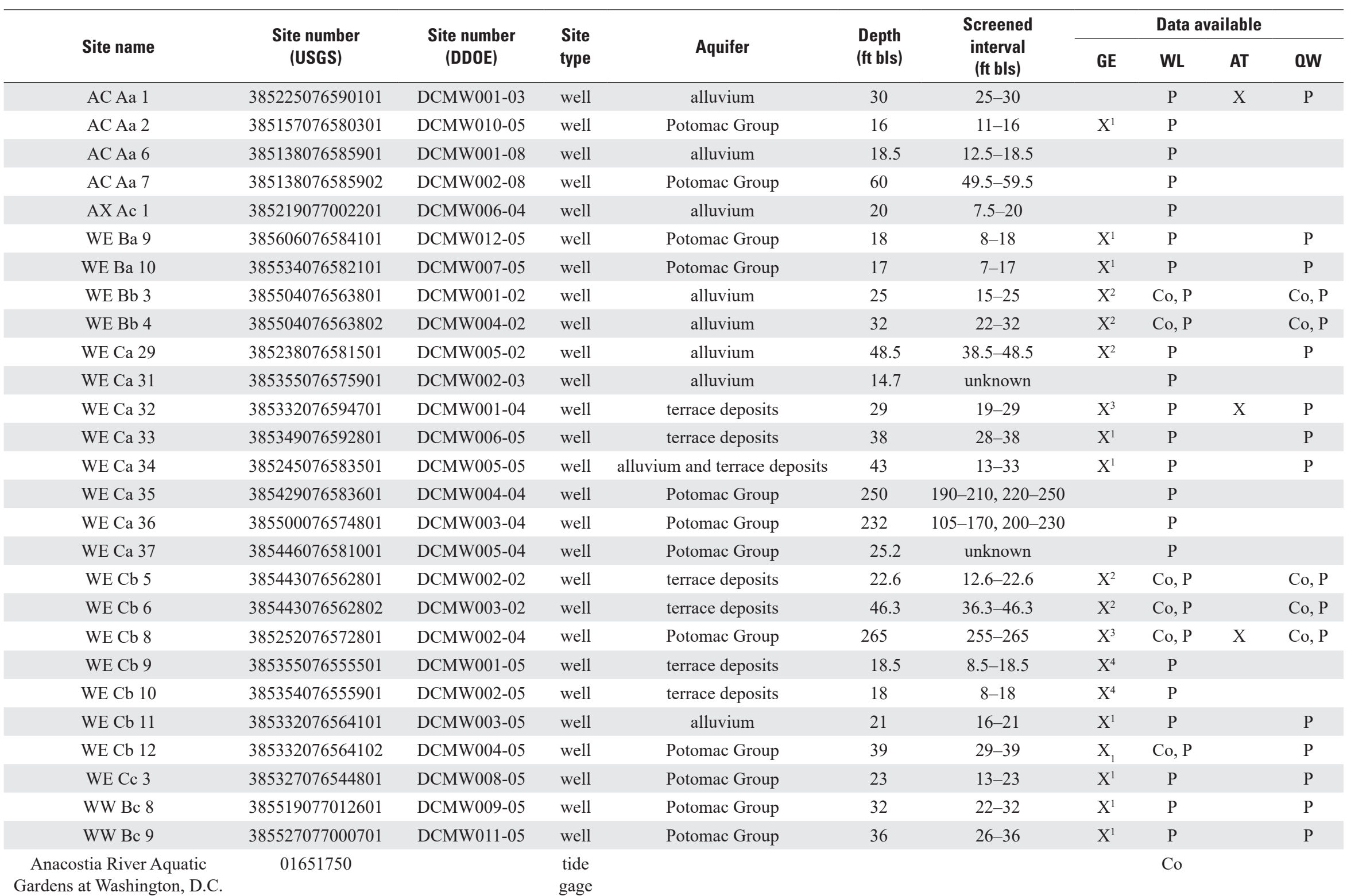

\footnotetext{
${ }^{1}$ See Appendix 1.
}

${ }^{2}$ Tenbus, 2003.

${ }^{3}$ D.C. Water Resources Research Center, 1993a.

${ }^{4}$ D.C. Water Resources Research Center, 1993b. 
Table 2. Summary of selected lithologic description locations in and near the tidal Anacostia River watershed, Washington, D.C.

$\left[{ }^{\circ}\right.$, ', ", degrees, minutes, seconds; ft, feet; USGS, U.S. Geological Survey; DC WASA LTCP, District of Columbia Water and Sewer Authority long-term control plan project]

\begin{tabular}{|c|c|c|c|c|c|c|}
\hline Site name & $\begin{array}{l}\text { Altitude } \\
\text { of land } \\
\text { surface } \\
\text { (ft) }\end{array}$ & Latitude & Longitude & $\begin{array}{c}\text { Total } \\
\text { depth } \\
\text { of } \\
\text { hole } \\
\text { (ft) }\end{array}$ & $\begin{array}{l}\text { Geophysical } \\
\text { logs } \\
\text { available }\end{array}$ & Reference \\
\hline AC Aa 2 & 125.59 & $38^{\circ} 51^{\prime} 57.4^{\prime \prime}$ & $76^{\circ} 58^{\prime} 03.3^{\prime \prime}$ & 24 & & USGS boring, described by C. Klohe on March 6, 2006 \\
\hline $\mathrm{AC} \mathrm{Ab} 3$ & 205 & $38^{\circ} 52^{\prime} 07.1^{\prime \prime}$ & $76^{\circ} 57^{\prime} 07.6^{\prime \prime}$ & 36 & & USGS boring, described by C. Klohe on March 13, 2006 \\
\hline Arena Stage & 14 & $38^{\circ} 52^{\prime} 37.01^{\prime \prime}$ & $77^{\circ} 01^{\prime} 12.97^{\prime \prime}$ & 183 & Yes & Somes, 2003 \\
\hline AX Ac 2, BPS-42 & 10.16 & $38^{\circ} 52^{\prime} 28.39^{\prime \prime}$ & $77^{\circ} 00^{\prime} 11.91^{\prime \prime}$ & 326 & Yes & $\begin{array}{l}\text { DC Clean Rivers Project boring, Anthony Harding, DC Clean Rivers } \\
\text { Project, written commun., August 12, } 2011\end{array}$ \\
\hline DC 2 & 19.26 & $38^{\circ} 54^{\prime} 35.01^{\prime \prime}$ & $76^{\circ} 56^{\prime} 16.97^{\prime \prime}$ & 400 & & Otton, 1955 \\
\hline DC Aquatic Resource Center PW-2 & 16 & $38^{\circ} 52^{\prime} 42.01^{\prime \prime}$ & $76^{\circ} 58^{\prime} 09.96^{\prime \prime}$ & 398 & Yes & HSI Geotrans, 1998 \\
\hline MW-2 & 82.35 & $38^{\circ} 54^{\prime} 23.00^{\prime \prime}$ & $77^{\circ} 00^{\prime} 44.97^{\prime \prime}$ & 47 & & DCWRRC, 1993a \\
\hline PG Cc 13 & 209.65 & $38^{\circ} 58^{\prime} 30.00^{\prime \prime}$ & $76^{\circ} 59^{\prime} 43.97^{\prime \prime}$ & 134 & & Cooke and others, 1952 \\
\hline PG Cd 9 & 135.4 & $38^{\circ} 56^{\prime} 00.01^{\prime \prime}$ & $76^{\circ} 51^{\prime} 57.97^{\prime \prime}$ & 160 & & Cooke and others, 1952 \\
\hline PG Dc 1 & 290 & $38^{\circ} 51^{\prime} 19^{\prime \prime}$ & $76^{\circ} 56^{\prime} 05^{\prime \prime}$ & 365 & & Cooke and others, 1952 \\
\hline PG Dc 3 & 290 & $38^{\circ} 50^{\prime} 24^{\prime \prime}$ & $76^{\circ} 56^{\prime} 32^{\prime \prime}$ & 388 & & Cooke and others, 1952 \\
\hline PG Dc 4 & 250 & $38^{\circ} 50^{\prime} 47^{\prime \prime}$ & $76^{\circ} 57^{\prime} 10^{\prime \prime}$ & 620 & & Cooke and others, 1952 \\
\hline PG Eb 1 & 14.3 & $38^{\circ} 48^{\prime} 42.00^{\prime \prime}$ & $77^{\circ} 00^{\prime} 21.97^{\prime \prime}$ & 603 & & Cooke and others, 1952 \\
\hline SAS-001 & 8.4 & $38^{\circ} 52^{\prime} 20.87^{\prime \prime}$ & $77^{\circ} 00^{\prime} 15.49^{\prime \prime}$ & 250 & & $\begin{array}{l}\text { DC WASA LTCP boring described by Camp Dresser \& McKee Inc.-- } \\
\text { Hack Mott Mcdonald, James Shaughnessy, written commun., February } \\
2008\end{array}$ \\
\hline SAS-002 & 13 & $38^{\circ} 52^{\prime} 09.39^{\prime \prime}$ & $77^{\circ} 00^{\prime} 06.12^{\prime \prime}$ & 156 & & DC WASA LTCP boring described by C. Dieter on September 11, 2007 \\
\hline SAS-006 & 12.3 & $38^{\circ} 53^{\prime} 01.39^{\prime \prime}$ & $76^{\circ} 58^{\prime} 16.65^{\prime \prime}$ & 182 & & DC WASA LTCP boring described by C. Dieter on February 21, 2008 \\
\hline SAS-101 & 14.9 & $38^{\circ} 51^{\prime} 55.99^{\prime \prime}$ & $76^{\circ} 59^{\prime} 36.20^{\prime \prime}$ & 191 & & DC WASA LTCP boring described by C. Dieter on February 7, 2008 \\
\hline SAS-102 & 12 & $38^{\circ} 51^{\prime} 51.81^{\prime \prime}$ & $77^{\circ} 00^{\prime} 03.53^{\prime \prime}$ & 195 & & DC WASA LTCP boring described by C. Dieter on February 7, 2008 \\
\hline SAS-103 & 10 & $38^{\circ} 52^{\prime} 28.78^{\prime \prime}$ & $77^{\circ} 00^{\prime} 13.38^{\prime \prime}$ & 152.5 & & DC WASA LTCP boring described by C. Dieter on September 11, 2007 \\
\hline SAS-104 & 6.3 & $38^{\circ} 52^{\prime} 40.83^{\prime \prime}$ & $76^{\circ} 58^{\prime} 42.99^{\prime \prime}$ & 175 & & DC WASA LTCP boring described by C. Dieter on September 13, 2007 \\
\hline SAS-106 & 13 & $38^{\circ} 53^{\prime} 46.70^{\prime \prime}$ & $76^{\circ} 58^{\prime} 06.63^{\prime \prime}$ & 166 & & DC WASA LTCP boring described by C. Dieter on February 8, 2008 \\
\hline SAS-107 & 30.4 & $38^{\circ} 53^{\prime} 59.57^{\prime \prime}$ & $76^{\circ} 58^{\prime} 09.18^{\prime \prime}$ & 166 & & DC WASA LTCP boring described by C. Dieter on February 14, 2008 \\
\hline SAS-108 & 69.4 & $38^{\circ} 54^{\prime} 39.10^{\prime \prime}$ & $76^{\circ} 59^{\prime} 08.82^{\prime \prime}$ & 172 & & DC WASA LTCP boring described by C. Dieter on September 19, 2007 \\
\hline SAS-109 & 4 & $38^{\circ} 52^{\prime} 16.50^{\prime \prime}$ & $76^{\circ} 59^{\prime} 15.31^{\prime \prime}$ & 177 & & DC WASA LTCP boring described by C. Dieter on September 12, 2007 \\
\hline SAS-110 & 7.2 & $38^{\circ} 52^{\prime} 31.87^{\prime \prime}$ & $76^{\circ} 58^{\prime} 37.78^{\prime \prime}$ & 177 & & DC WASA LTCP boring described by C. Dieter on September 19, 2007 \\
\hline SAS-111 & 13 & $38^{\circ} 52^{\prime} 49.82^{\prime \prime}$ & $76^{\circ} 58^{\prime} 08.50^{\prime \prime}$ & 185 & & DC WASA LTCP boring described by C. Dieter on September 20, 2007 \\
\hline SAS-112 & 10.3 & $38^{\circ} 53^{\prime} 15.36^{\prime \prime}$ & $76^{\circ} 58^{\prime} 11.37^{\prime \prime}$ & 175 & & DC WASA LTCP boring described by C. Dieter on February 8, 2008 \\
\hline
\end{tabular}


Table 2. Summary of selected lithologic description locations in and near the tidal Anacostia River watershed, Washington, D.C.-Continued

$\left[{ }^{\circ}\right.$, ', ", degrees, minutes, seconds; ft, feet; USGS, U.S. Geological Survey; DC WASA LTCP, District of Columbia Water and Sewer Authority long-term control plan project]

\begin{tabular}{|c|c|c|c|c|c|c|}
\hline Site name & $\begin{array}{c}\text { Altitude } \\
\text { of land } \\
\text { surface } \\
\text { (ft) }\end{array}$ & Latitude & Longitude & $\begin{array}{c}\text { Total } \\
\text { depth } \\
\text { of } \\
\text { hole } \\
\text { (ft) }\end{array}$ & $\begin{array}{c}\text { Geophysical } \\
\text { logs } \\
\text { available }\end{array}$ & Reference \\
\hline SAS-201 & 20.2 & $38^{\circ} 49^{\prime} 07.93^{\prime \prime}$ & $77^{\circ} 01^{\prime} 05.78^{\prime \prime}$ & 216 & & DC WASA LTCP boring described by C. Dieter on February 15, 2008 \\
\hline SAS-202 & 157.7 & $38^{\circ} 49^{\prime} 47.03^{\prime \prime}$ & $77^{\circ} 00^{\prime} 52.12^{\prime \prime}$ & 336 & & DC WASA LTCP boring described by C. Dieter on February 15, 2008 \\
\hline SAS-203 & 33.2 & $38^{\circ} 51^{\prime} 29.30^{\prime \prime}$ & $77^{\circ} 00^{\prime} 10.46^{\prime \prime}$ & 206 & & DC WASA LTCP boring described by C. Dieter on September 12, 2007 \\
\hline SAS-204 & 158 & $38^{\circ} 50^{\prime} 55.03^{\prime \prime}$ & $77^{\circ} 00^{\prime} 20.65^{\prime \prime}$ & 329 & & DC WASA LTCP boring described by C. Dieter on February 14, 2008 \\
\hline USNA PW-3 & 14 & $38^{\circ} 54^{\prime} 34.00^{\prime \prime}$ & $76^{\circ} 57^{\prime} 32.97^{\prime \prime}$ & 306 & Yes & Schnabel Engineering Associates, 1995 \\
\hline WE Ba 9 & 81.26 & $38^{\circ} 56^{\prime} 06.5^{\prime \prime}$ & $76^{\circ} 58^{\prime} 41.4^{\prime \prime}$ & 24 & & USGS boring, described by C. Klohe on March 102006 \\
\hline WE Ba 10 & 74.43 & $38^{\circ} 55^{\prime} 34.4^{\prime \prime}$ & $76^{\circ} 58^{\prime} 21.4^{\prime \prime}$ & 20 & & USGS boring, described by C. Klohe on March 7, 2006 \\
\hline WE Ca 6 & 80 & $38^{\circ} 53^{\prime} 30.00^{\prime \prime}$ & $76^{\circ} 59^{\prime} 46.98^{\prime \prime}$ & 340 & & Hansen, 1968 \\
\hline WE Ca 30 & 3 & $38^{\circ} 54^{\prime} 05.8^{\prime \prime}$ & $76^{\circ} 57^{\prime} 34.2^{\prime \prime}$ & 30.5 & & Tenbus, 2003 \\
\hline WE Ca 32, MW-4 & 80 & $38^{\circ} 53^{\prime} 32.00^{\prime \prime}$ & $76^{\circ} 59^{\prime} 46.98^{\prime \prime}$ & 42 & & DCWRRC, 1993a \\
\hline WE Ca 33 & 67.75 & $38^{\circ} 53^{\prime} 49.8^{\prime \prime}$ & $76^{\circ} 59^{\prime} 28.3^{\prime \prime}$ & 40 & & USGS boring, described by C. Klohe on August 5, 2005 \\
\hline WE Ca 34 & 19.61 & $38^{\circ} 52^{\prime} 45.6^{\prime \prime}$ & $76^{\circ} 58^{\prime} 35.1^{\prime \prime}$ & 45.5 & & USGS boring, described by C. Klohe on August,10 2005 \\
\hline WE Ca 35, USNA PW-2 & 149.6 & $38^{\circ} 54^{\prime} 29.20^{\prime \prime}$ & $76^{\circ} 58^{\prime} 36.00^{\prime \prime}$ & 265 & & A.C. Schultes of Maryland, Inc, Job \#2616 \\
\hline WE Ca 38 & 45 & $38^{\circ} 54^{\prime} 16.07^{\prime \prime}$ & $76^{\circ} 58^{\prime} 15.54^{\prime \prime}$ & 24 & & USGS boring, described by C. Klohe on March 13, 2006 \\
\hline WE Cb 7 & 4 & $38^{\circ} 54^{\prime} 59.5^{\prime \prime}$ & $76^{\circ} 56^{\prime} 34.0^{\prime \prime}$ & 27.9 & & Tenbus, 2003 \\
\hline WE Cb 8, MW-1 & 61 & $38^{\circ} 52^{\prime} 52.00^{\prime \prime}$ & $76^{\circ} 57^{\prime} 27.97^{\prime \prime}$ & 277 & & DCWRRC, 1993a \\
\hline WE Cb 9, MW-B1 & 45.52 & $38^{\circ} 53^{\prime} 55.00^{\prime \prime}$ & $76^{\circ} 55^{\prime} 54.97^{\prime \prime}$ & 19 & & DCWRRC, $1993 \mathrm{~b}$ \\
\hline WE Cb 11 & 59.99 & $38^{\circ} 53^{\prime} 32.1^{\prime \prime}$ & $76^{\circ} 56^{\prime} 41.2^{\prime \prime}$ & 24 & & USGS boring, described by C. Klohe on March 13, 2006 \\
\hline $\mathrm{WE} \mathrm{Cb} 12$ & 60.59 & $38^{\circ} 53^{\prime} 32.1^{\prime \prime}$ & $76^{\circ} 56^{\prime} 41.2^{\prime \prime}$ & 81 & & USGS boring, described by C. Klohe on March 102006 \\
\hline WE Cc 3 & 88.7 & $38^{\circ} 53^{\prime} 27.0^{\prime \prime}$ & $76^{\circ} 54^{\prime} 48.5^{\prime \prime}$ & 24 & & USGS boring, described by C. Klohe on March 2, 2006 \\
\hline WW Bc 8 & 123.39 & $38^{\circ} 59^{\prime} 19.3^{\prime \prime}$ & $77^{\circ} 01^{\prime} 26.9^{\prime \prime}$ & 32 & & USGS boring, described by C. Klohe on March 1, 2006 \\
\hline WW Bc 9 & 133.6 & $38^{\circ} 55^{\prime} 27.8^{\prime \prime}$ & $77^{\circ} 00^{\prime} 07.7^{\prime \prime}$ & 36 & & USGS boring, described by C. Klohe on March 7, 2006 \\
\hline WW Cc 26 & 65 & $38^{\circ} 54^{\prime} 10.00^{\prime \prime}$ & $77^{\circ} 01^{\prime} 53.97^{\prime \prime}$ & 85 & & Hansen, 1968 \\
\hline WW Cc 37 & 84 & $38^{\circ} 54^{\prime} 43.41^{\prime \prime}$ & $77^{\circ} 01^{\prime} 34.66^{\prime \prime}$ & 36 & & USGS boring, described by R. Starsoneck on August 11, 2005 \\
\hline
\end{tabular}


Seventeen monitoring wells were constructed and developed at selected coring locations. Five of these wells (WE Bb 3, WE Bb 4, WE Cb 5, WE Cb 6, and WE Ca 29) were constructed at onshore coring locations near the Anacostia River in July 2002 (Miller and Klohe, 2003; Tenbus, 2003) (fig. 2, table 1). A truck-mounted solid-stem auger was used to deepen some core holes beyond the depth attainable through vibracoring. The 12 remaining wells were installed at selected locations throughout the watershed in August 2005 (AC Aa 2, WE Ba 9, WE Ba 10, WE Ca 33, WE Ca 34, WE $\mathrm{Cb} 11, \mathrm{WE} \mathrm{Cb} 12$, WE Cc 3, WW Bc 8, and WW Bc 9) and May 2008 (AC Aa 6 and AC Aa 7) using a hollow-stem auger or a truck-mounted Geoprobe. Wells were constructed of 1or 2-inch (in.)-diameter threaded polyvinyl chloride (PVC) casing and slotted screen. Sand was used to fill the annulus between the well screen and core hole, and bentonite was used to grout the annulus above the screen interval to a concrete plug at the surface. Wells were generally screened within the uppermost water-bearing zone at each location; some wells are nested at different depths at the same location (WE Bb 3 and WE Bb4, WE Cb 5 and WE Cb 6, WE Cb 11 and WE Cb 12, and AC Aa 6 and AC Aa 7). All wells were developed through mechanical surging and pumping to remove fine material from the screen and sand pack. Development continued until water clarity increased, turbidity decreased, and water temperature and specific conductance stabilized.

A tide gage was constructed on a seawall along the Anacostia River near the Kenilworth Aquatic Gardens (fig. 2, table 1, USGS station 01651750) in May 2004. A perforated horizontal steel pipe extends from the seawall approximately $8 \mathrm{ft}$ into the river. The pipe is attached to the base of a vertical steel pipe at the seawall, which is in turn attached to an instrument enclosure at its top.

\section{Hydrologic Measurements}

Measurements were made to estimate groundwater-flow gradients and variability, and hydrologic properties of Coastal Plain sediment in the study area. Groundwater levels were measured periodically or continuously in selected monitoring wells. In addition, aquifer tests were conducted to estimate hydrologic properties of selected Coastal Plain aquifers, and tidal fluctuations in the Anacostia River were recorded at the installed tide gage.

Groundwater levels were measured to estimate groundwater-flow gradients, and document seasonal or temporal variability in groundwater levels in the tidal Anacostia River watershed study area. Groundwater levels were recorded continuously at 30-minute intervals in selected wells by In-Situ sondes from 2003 through 2007 (table 1, Appendix 2). Sondes were typically installed within the screened interval of the well. Monthly to quarterly servicing of the sondes included cleaning, battery replacement, and calibration checks against manual water-level measurements. Sondes were reset to match the manual water-level measurements if the values were more than $0.02 \mathrm{ft}$ different. Manual water-level measurements were also made periodically (typically monthly to quarterly) in additional monitoring wells using an electric water-level tape or chalked steel tape (table 1, Appendix 3).

Tidal variations in water level in the Anacostia River were recorded continuously from June 2004 to October 2017 at the tide gage that was installed near Kenilworth Aquatic Gardens. Instantaneous measurement data (6-minute interval) from 2004 through 2007 are available in Appendixes $4 A$ through $4 D$. Instantaneous data from 2008 through 2017, and daily data from 2004 through 2017, are available through the USGS National Water Information System database (U.S. Geological Survey, 2017). A data logger in the instrument shelter recorded varying water levels reflected in a float and counter-weight system installed in the vertical pipe. Water levels were recorded every 6 minutes at $0,6,12,18,24$, $30,36,42,48$, and 54 minutes past the hour for consistency with National Oceanic and Atmospheric Administration gages, and transmitted via satellite to USGS databases. Data were reviewed periodically, and the tide gage was visited periodically for calibration checks and equipment servicing.

Aquifer tests (slug tests) (Butler, 1998) were conducted to estimate the hydraulic properties of aquifer sediments within which selected wells are screened (table 3). Multiple tests (such as rising head, falling head, and slugs of different volumes) were generally conducted at each well, and analytical methods for resulting data were selected on the basis of individual hydrogeologic conditions (Cooper and others, 1967; Bouwer and Rice, 1976; Greene and Shapiro, 1995). Most wells do not penetrate the entire thickness of aquifer sediments, and estimated hydraulic properties may therefore only apply to screened intervals. Only later-time data were used in the interpretation of slug tests at well WE Ca 32, on the assumption that the quick initial responses observed in water levels during the tests were reflective of properties of the well filter pack rather than aquifer sediments (Butler, 1998). Multiple unsuccessful slug tests at wells WE Ca 31, WE Ca 33, and WE Ca 34 may be indicative of low-permeability sediments surrounding the well screen or a partially clogged well screen (even after multiple attempts to redevelop the wells).

\section{Water-Quality Sampling}

Water samples collected periodically from selected wells were analyzed for chemical constituents indicative of natural and human influences on groundwater quality. In addition, selected parameters were recorded continuously in some wells to document temporal and seasonal variation in groundwater quality (table 1). 
Table 3. Summary and results of aquifer slug tests on selected wells.

[T, transmissivity; $\mathrm{K}$, horizontal hydraulic conductivity; $\mathrm{ft} / \mathrm{d}$, foot per day; $\mathrm{ft}^{2} / \mathrm{d}$, foot squared per day]

\begin{tabular}{cccccc}
\hline Site name & $\begin{array}{c}\text { Aquifer } \\
\text { (type) }\end{array}$ & Analysis method & \multicolumn{2}{c}{ Estimated aquifer properties } \\
\cline { 4 - 6 } AC Aa 1 & $\begin{array}{c}\text { surficial aquifer system } \\
\text { (unconfined) }\end{array}$ & $\begin{array}{c}\text { Cooper and others, 1967; } \\
\text { Greene and Shapiro, 1995 }\end{array}$ & 100 & 20 & $2.138 \mathrm{E}-4$ \\
WE Ca 32 & $\begin{array}{c}\text { terrace deposits } \\
\text { (unconfined) }\end{array}$ & Bouwer and Rice, 1976 & 100 & 6 & Storage \\
\hline WE Cb 8 & $\begin{array}{c}\text { Patuxent Aquifer } \\
\text { (confined) }\end{array}$ & $\begin{array}{c}\text { Cooper and others, 1967; } \\
\text { Greene and Shapiro, 1995 }\end{array}$ & 200 & 20 & $2.545 \mathrm{E}-8$ \\
\hline
\end{tabular}

Samples were collected from September through December 2005 from 17 monitoring wells in three geologic settings (Klohe and Debrewer, 2007); 5 of these wells had previously been sampled in August 2002 (WE Bb 3, WE Bb 4, WE Cb 5, WE Cb 6, and WE Ca 29) (Miller and Klohe, 2003). Wells were purged (generally a minimum of three well volumes) until $\mathrm{pH}$, temperature, dissolved oxygen, turbidity, and specific conductance stabilized prior to sampling. Samples were collected with a peristaltic or stainless-steel submersible pump. Subsamples intended for analysis of dissolved constituents were passed through a 0.45 - micrometer $(\mu \mathrm{m})$ cellulose-nitrate filter (for inorganics) or a $0.70-\mu \mathrm{m}$ baked glass-fiber filter (for organics). Selected preservatives were added, as necessary, and samples were chilled and shipped overnight to the USGS National Water Quality Laboratory, in Denver, Colorado, or Severn Trent Laboratory, in Arvada, Colorado. for analysis. Samples were analyzed for selected major ions, trace elements, nutrients, pesticides and pesticide degradants, VOCs, semi-volatile organic compounds (SVOCs), phenols, PCBs, and oil and grease (Miller and Klohe, 2003; Klohe and Debrewer, 2007).

Selected water-quality parameters were recorded continuously in a limited number of monitoring wells. In-Situ TROLL 9000 multi-parameter sondes installed in selected monitoring wells (WE Bb 3, WE Bb 4, WE Cb 5, WE Cb 6, $\mathrm{WE} \mathrm{Cb} 8$, and WE $\mathrm{Cb}$ 12) recorded specific conductance, $\mathrm{pH}$, reduction/oxidation (redox) potential, temperature, dissolved oxygen, and barometric pressure, as well as water levels, at 30-minute intervals from June 2003 through 2006. Periodic calibration checks were done using a multipoint approach for $\mathrm{pH}$ and conductance, and dissolved-oxygen calibration was done using an air calibration chamber in water. Occasional missing records resulted from faulty probes, fouling, or unusual conditions (such as flooding from Tropical Storm Isabel).

\section{Geologic Framework}

The Anacostia River watershed within Washington, D.C. is underlain by unconsolidated sediments of the Atlantic
Coastal Plain Physiographic Province (Fenneman and Johnson, 1946). These sediments form a wedge that thickens from $0 \mathrm{ft}$ at the Fall Line (the unconformity between the Piedmont and Coastal Plain Physiographic Provinces) to more than 1,400 ft in the southeastern part of the Washington, D.C. metropolitan area (Reed and Obermeier, 1982), and lie unconformably on the sloping surface of much older crystalline rocks of the Piedmont Province (figs. 3, 4A-D). Unconsolidated sediments of the Atlantic Coastal Plain vary laterally and vertically in color, texture, and permeability, reflecting a complex history of erosional and depositional processes over millions of years. The oldest Atlantic Coastal Plain deposits are fluvial sediments of the Cretaceous Potomac Group. These are overlain in places by younger marine deposits and by surficial upland gravels and alluvial and terrace deposits (table 4).

\section{The Potomac Group}

The oldest Coastal Plain sediments in the study area are Cretaceous fluvial deposits of the Potomac Group (Southworth and Denenny, 2006), including a sand-dominated lithofacies (previously referred to as the "Patuxent Formation," and hereinafter referred to as the "Potomac Group sand-dominated lithofacies") and an overlying clay-dominated lithofacies (previously referred to as the "Arundel" and "Patapsco Formations," and hereinafter referred to as the "Potomac Group clay-dominated lithofacies") (Mathews, 1933; Cooke and others, 1952; Johnston, 1964; Vroblesky and Fleck, 1991) (figs. 3, 4A-D, table 4). The Potomac Group sand-dominated lithofacies includes some pebbles and multicolored clay and rests unconformably upon the basal Piedmont rocks. In Washington, D.C., the depth to the Piedmont rocks from land surface varies: $85 \mathrm{ft}$ at WW Cc 26 (Hansen, 1968), $182 \mathrm{ft}$ at Arena Stage (Somes, 2003), $306 \mathrm{ft}$ at USNA PW-3 (Schnabel Engineering Associates, 1995), $316 \mathrm{ft}$ at AX Ac 2 (Appendix 1), $328 \mathrm{ft}$ at WE Ca 6 (Hansen, 1968), $377 \mathrm{ft}$ at DC2 (Otton, 1955), and $398 \mathrm{ft}$ at DC Aquatic Resource Center PW-2, (HSI Geotrans, Inc., 1998). The Potomac Group clay-dominated lithofacies includes some sand, but is mostly massive, mottled, silty clay (Southworth and Denenny, 2006). 


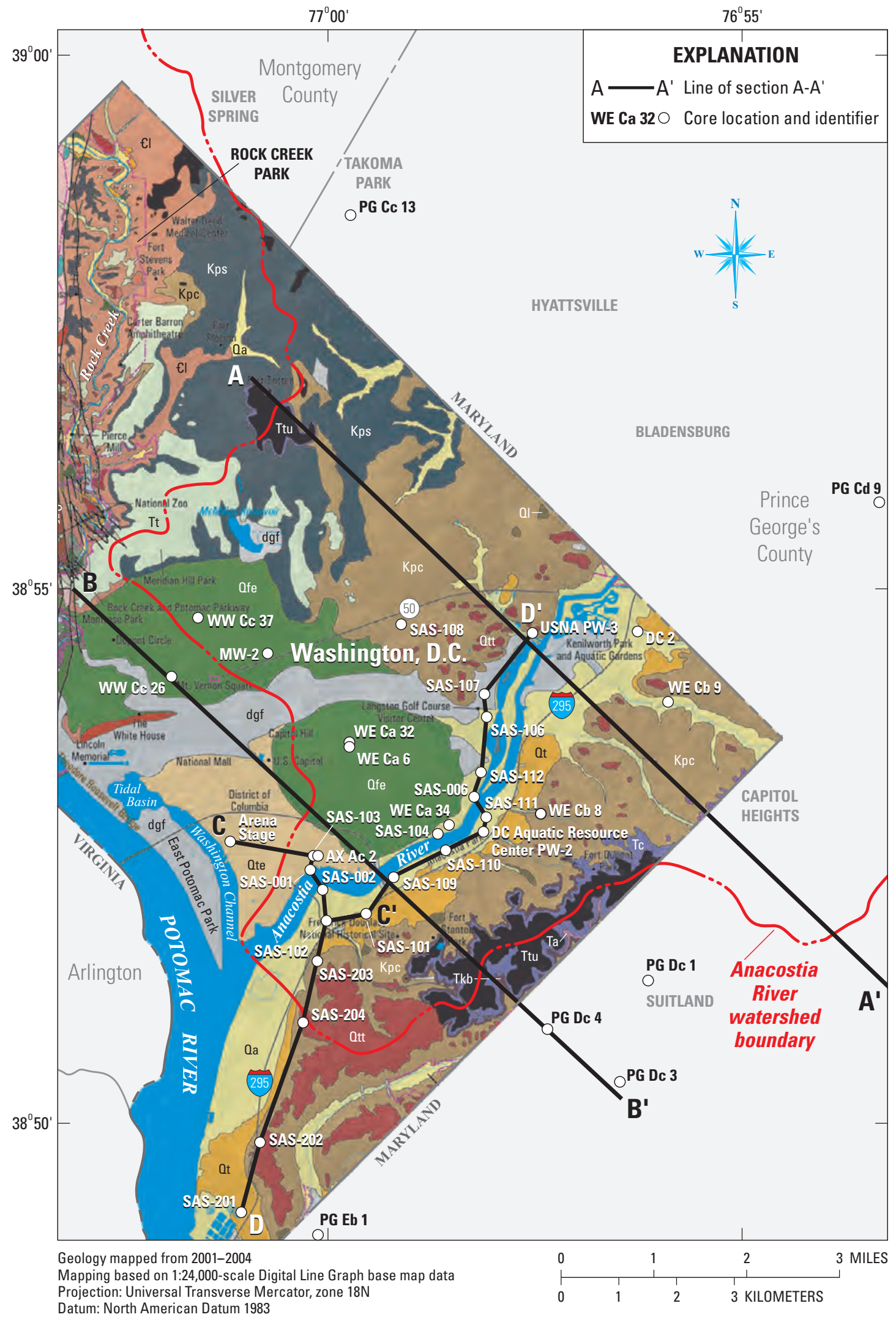

Figure 3. Generalized geology of the tidal Anacostia River watershed, selected lithologic description locations, and cross-section locations, Washington, D.C. (modified from Southworth and Denenny, 2006). 


\begin{tabular}{|c|c|}
\hline \multicolumn{2}{|c|}{ GEOLOGIC MAP UNITS } \\
\hline \multicolumn{2}{|r|}{ QUATERNARY AND CENOZOIC SURFICIAL MATERIALS } \\
\hline dgf & Disturbed ground and artificial fill \\
\hline Qa & Alluvium (Holocene) \\
\hline Qt & Terrace deposits, low level (Holocene and Pleistocene) \\
\hline Qc & Colluvium (Holocene and Pleistocene) \\
\hline Ql & Landslide (Holocene and Pleistocene) \\
\hline Qte & Low-level fluvial and estuarine deposits (Pleistocene) \\
\hline Ofe & Upper-level fluvial and estuarine deposits (Pleistocene) \\
\hline Qtt & Terrace deposits, upper level (Pleistocene and Tertiary) \\
\hline \multicolumn{2}{|c|}{ TERTIARY COASTAL PLAIN DEPOSITS } \\
\hline $\mathrm{Tt}$ & Terrace deposits (Tertiary) \\
\hline Ttu & Highest level upland terrace deposits (Tertiary) \\
\hline Tc & Calvert Formation (middle Miocene) \\
\hline $\mathrm{Ta}$ & Aquia Formation (upper Paleocene) \\
\hline TKb & $\begin{array}{l}\text { Brightseat Formation and Monmouth Group, undivided } \\
\text { (lower Paleocene and upper Cretaceous) }\end{array}$ \\
\hline CRE & ACEOUS COASTAL PLAIN DEPOSITS \\
\hline Kpc & Potomac Group clay-dominated lithofacies \\
\hline Kps & Potomac Group sand-dominated lithofacies \\
\hline
\end{tabular}

Figure 3. Generalized geology of the tidal Anacostia River watershed, selected lithologic description locations, and crosssection locations, Washington, D.C. (modified from Southworth and Denenny, 2006).-Continued

The lower part of the clay facies (previously referred to as the "Arundel Formation") is almost entirely dark-colored clay, with some iron-carbonate nodules and lignitized woody material. The uppermost Potomac Group deposits in the area (previously referred to as the "Patapsco Formation") include a basal clay layer (commonly maroon in color) and an upper layer of mixed texture (sand and clay). Although the Potomac Group varies considerably in texture, collectively, it is primarily fine-grained. More than 70 percent of one $946-\mathrm{ft}$ vertical section through the Potomac Group just east of the study area in Prince George's County, Maryland is composed primarily of clay (Cooke and others, 1952). It is important to note that the Potomac Group sand-dominated lithofacies and the Potomac Group clay-dominated lithofacies are each on the order of tens of feet in thickness. Therefore, although the Potomac Group sand-dominated lithofacies includes some clay and the Potomac Group clay-dominated lithofacies contains some sand, individual layers (less than $10 \mathrm{ft}$ thick) of sand or clay should not be identified as the Potomac Group sand-dominated lithofacies or Potomac Group clay-dominated lithofacies, respectively.

The Potomac Group crops out and subcrops in a broad band that trends through the study area from northeast to southwest, and dips to the southeast beneath younger Tertiary and Quaternary deposits (Johnston, 1964; Southworth and Denenny, 2006; figs. 3, $4 A-D$ ). In general, the clay facies separates the underlying Potomac Group sand-dominated lithofacies deposits from overlying younger sediments. The contact between the Potomac Group sand-dominated and clay-dominated lithofacies crops out in the northwestern part of the study area, but subcrops beneath younger Quaternary deposits to the south. Although the uppermost part of the Potomac Group clay-dominated lithofacies includes sediments of variable texture, the transition from finer-grained deposits to coarser-grained deposits crops out or subcrops southeast of the Anacostia River, and the Potomac Group clay contains predominantly fine-grained sediments within the study area (figs. 3, 4A-D).

Potomac Group sediments may be missing from the geologic column in parts of the tidal Anacostia River watershed, particularly near the Anacostia River. Sediments of the Potomac Group deposited during the Cretaceous Period have been subsequently removed by erosion due to downcutting of the Potomac and Anacostia Rivers during periods of relatively low sea level. Coring revealed particularly thick (greater than $100 \mathrm{ft}$ ) alluvial and estuarine sequences around the lower Anacostia River near its mouth (fig. $4 C$, for example, cores SAS-001 and SAS-103). The river may have eroded completely through the Potomac Group clay-dominated lithofacies to the underlying sand-dominated lithofacies in this area. Further coring would be necessary to determine the lateral extent of missing clay-dominated lithofacies (figs. $4 C$, $4 D$, 5, Appendix 1). Another location where data indicate that the clay-dominated lithofacies is missing is beneath the northwestern bank of the Anacostia River near the South Capitol Street Bridge (Appendix 5). Data from this bridge crossing generally indicate the existence of the clay-dominated lithofacies from approximately $-25 \mathrm{ft}$ down to greater than $-75 \mathrm{ft}$ relative to mean sea level (msl) on the southeastern bank of the Anacostia River. The clay-dominated lithofacies thins and pinches out near the southeastern bank of the Anacostia River. Beneath the center of the current Anacostia River channel, a Quaternary paleochannel fill includes a clay-dominated lithofacies approximately 10 to $40 \mathrm{ft}$ thick (at -90 to $-120 \mathrm{ft}$ relative to $\mathrm{msl}$ ). The cross section also shows that from the center of the channel to the northwest bank, the lithology is primarily clayey sand, indicating that the clay-dominated lithofacies is missing beneath part of the Anacostia River. However, borings in the northwest part of the cross section are fairly shallow (50 to $75 \mathrm{ft}$ below land surface), limiting the interpretation of the presence or absence of the clay-dominated lithofacies. Because of the highly variable nature of fluvial depositional environments of the Potomac Group, as well as subsequent complex paleochannel erosional and alluvial and estuarine erosional and depositional environments, additional data would be necessary to determine the extent and location of areas where the clay-dominated lithofacies is not present. In such areas, the sand-dominated lithofacies would be in direct connection with shallower sand deposits (terrace or alluvial deposits). 

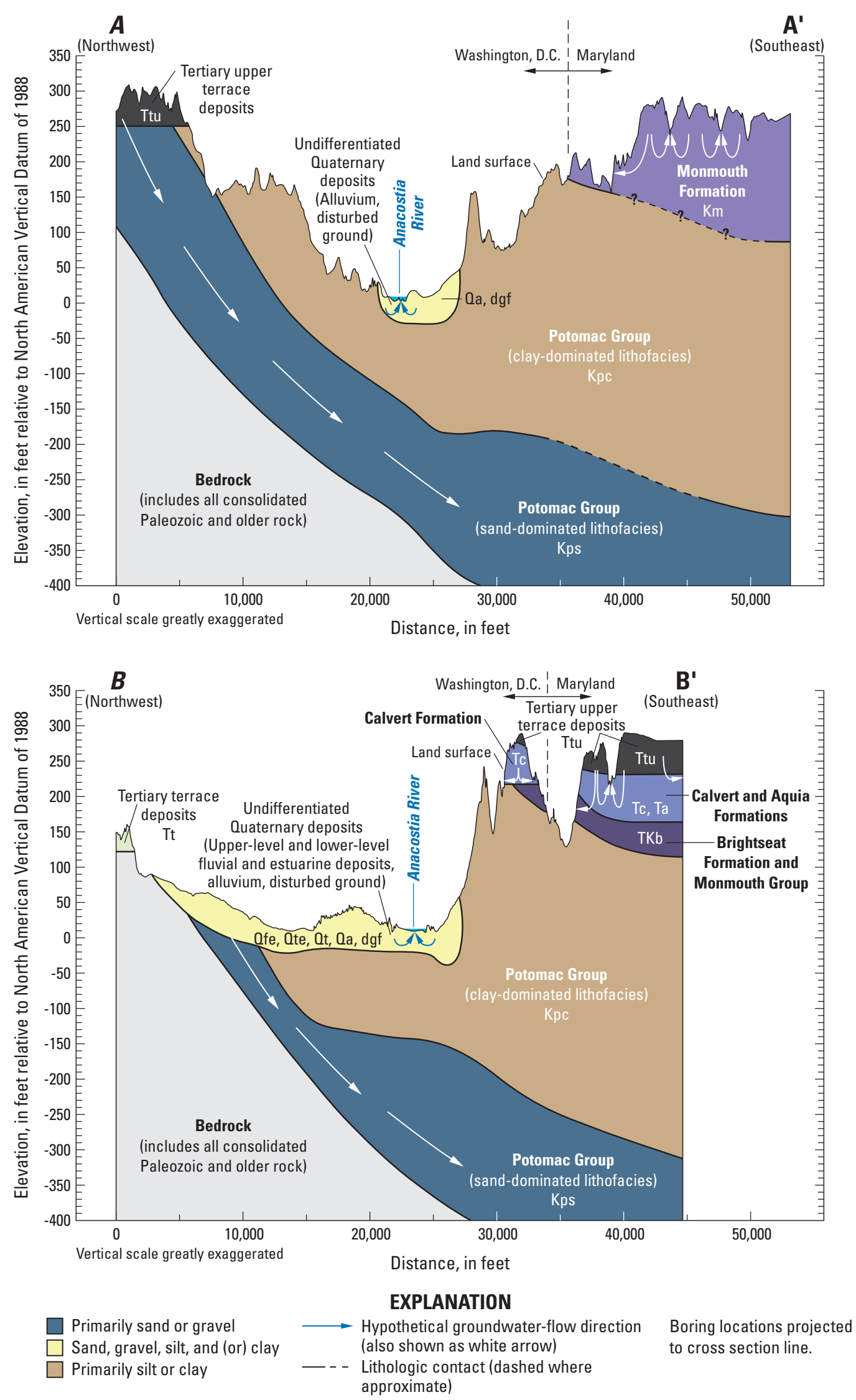

Figure 4A-B. Generalized geologic cross sections $A-A^{\prime}$ and $B-B^{\prime}$, showing hypothetical groundwater-flow directions in the tidal Anacostia River watershed, Washington, D.C. Refer to figure 3 for location of cross sections and geologic units. 


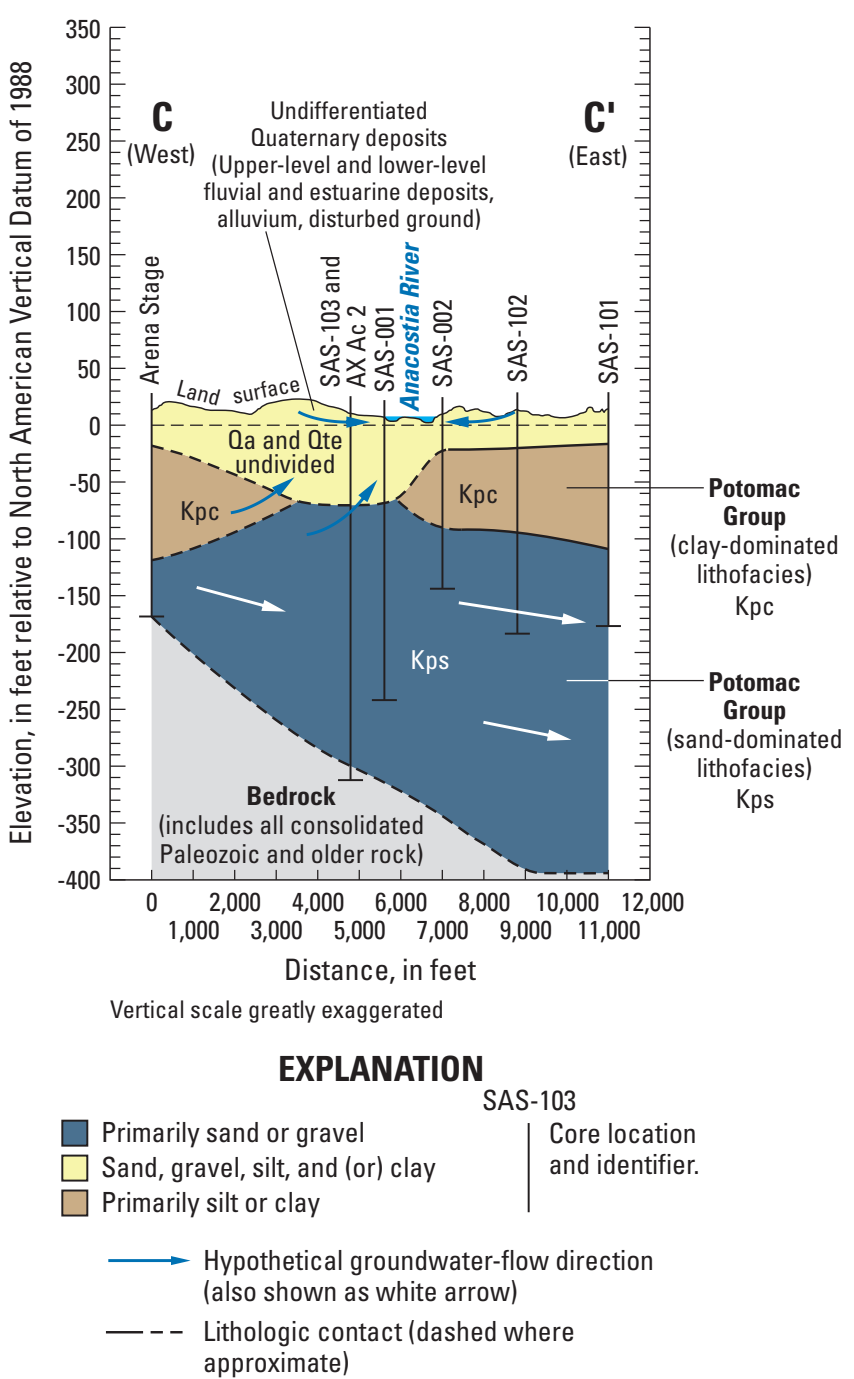

Figure $4 C$. Generalized geologic cross section $C-C^{\prime}$ showing hypothetical groundwater-flow directions in the tidal Anacostia River watershed, Washington, D.C. Refer to figure 3 for location of cross sections and geologic units.

\section{Upper Cretaceous and Tertiary Deposits}

The Potomac Group is overlain in parts of the study area and vicinity by marine and estuarine deposits of the Monmouth Group, Brightseat Formation, Aquia Formation, Marlboro Clay, and Nanjemoy and Calvert Formations (table 4; Cooke and others, 1952). These deposits are limited to uplands south of the Anacostia River in the extreme southeastern part of the study area (Johnston, 1964; Southworth and Denenny, 2006; figs. 3, 4C, 4D). The Monmouth Group is composed primarily of fine glauconitic or mica-rich sand, with a thin (2-ft) basal gravel bed just above its contact with the underlying Potomac Group (Cooke and others, 1952). The Aquia Formation includes green glauconitic sand, similar to that of the underlying Monmouth Formation. The Nanjemoy Formation also contains glauconitic sand, overlying the pink Marlboro Clay. Miocene-age Chesapeake Group sediments in the vicinity of the study area are predominantly dark gray to light gray clay (Cooke and others, 1952).

\section{Upper Tertiary and Younger Deposits}

The uppermost and youngest geologic units in the study area include coarse upland sediments, and more recent alluvial and terrace deposits along modern stream channels. Coarse deposits (primarily gravel and sand) occur as erosional remnants in relatively isolated uplands (Cooke and others, 1952; Johnston, 1964; Southworth and Denenny, 2006; figs. 3, 4B, table 4). The Anacostia River Valley and much of downtown Washington, D.C. near the confluence of the Anacostia and Potomac Rivers are underlain by Pleistocene fluvial and estuarine terrace deposits and more recent alluvium (Cooke and others, 1952; Johnston, 1964; Southworth and Denenny, 2006). Terrace deposits include fining-upward sequences of sediment (including gravel, sand, silt, and clay) formed as the ancient river valleys were flooded by rising sea levels. Holocene alluvium (primarily clay, sand, and gravel, usually only a few feet thick) occurs beneath the modern Anacostia River flood plain and channel (Johnston, 1964; Southworth and Denenny, 2006). 
D
(Southwest)

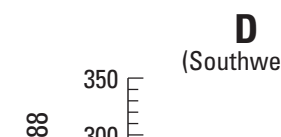<smiles>C1CCCCC1</smiles>

$\stackrel{\circ}{\frac{0}{4}} 300$

눌

言 200

그요

.

西

$-400+0$

Vertical scale greatly exaggerated
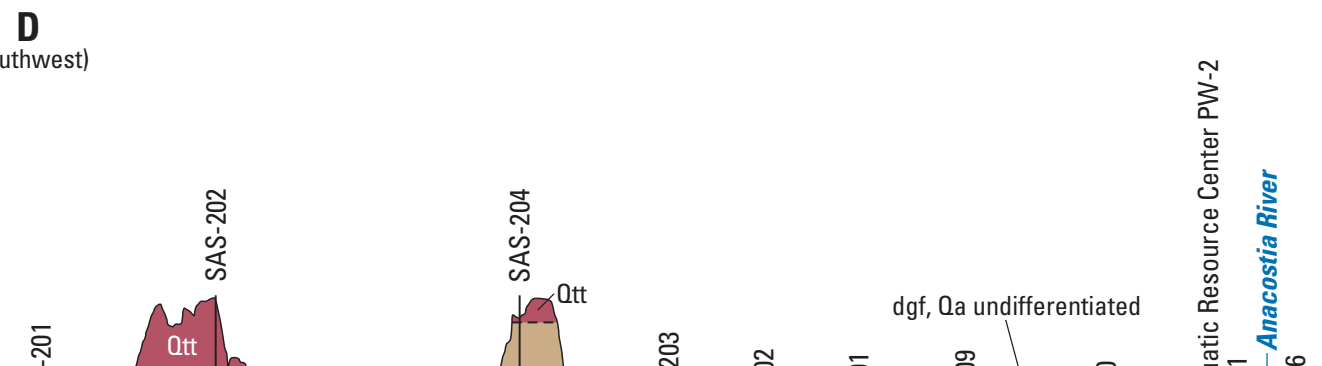

(Northeast)

Figure 4D. Generalized geologic cross section D-D' through the Coastal Plain sediments in the tidal Anacostia River watershed, Washington, D.C. Refer to figure 3 for location

of cross section and geologic units. Hypothetical flow directions are not shown on this section because they are primarily perpendicular to this cross section.

\section{EXPLANATION}

$\square \square$ Primarily sand or gravel
$\square$ Sand, gravel, silt, and (or) c $\square$ Sand, gravel, silt, and (or)
$\square$ Primarily silt or clay

\section{SAS-201}

Core location and identifier.

- - Lithologic contact (dashed where approximate) 
Table 4. Summary of Coastal Plain geologic and hydrogeologic units in the tidal Anacostia River watershed, Washington, D.C. and surrounding area.

\begin{tabular}{|c|c|c|c|c|c|c|}
\hline Age & \multicolumn{2}{|c|}{$\begin{array}{l}\text { Geologic units }^{1} \\
\text { (see figs. } 3 \text { and } 4 \text { ) }\end{array}$} & \multicolumn{2}{|c|}{ Previous geologic units ${ }^{2}$} & Description ${ }^{1,2}$ & Hydrogeologic units ${ }^{3}$ \\
\hline \multirow{4}{*}{ Quaternary } & \multirow{3}{*}{\multicolumn{2}{|c|}{$\begin{array}{l}\text { Disturbed ground, artificial } \\
\text { fill, alluvium, terrace deposits, } \\
\text { fluvial and estuarine deposits }\end{array}$}} & \multicolumn{2}{|c|}{ Alluvium } & $\begin{array}{l}\text { Variable sediments in modern stream channels and flood } \\
\text { plains. }\end{array}$ & \multirow{3}{*}{ Surficial aquifer system } \\
\hline & & & \multicolumn{2}{|c|}{ Pamlico Formation } & Fining upward sequence of gravel, sand, and silt. & \\
\hline & & & \multicolumn{2}{|c|}{ Wicomico Formation } & $\begin{array}{l}\text { Fining upward sequence of coarse gravel, overlain by } \\
\text { finer sand and silt. }\end{array}$ & \\
\hline & \multirow{2}{*}{\multicolumn{2}{|c|}{ Terrace deposits }} & \multirow{2}{*}{\multicolumn{2}{|c|}{ Sunderland Formation }} & Fining upward sequence of coarse gravel, sand, silt, and & \multirow{3}{*}{$\begin{array}{l}\text { Terrace deposits of the } \\
\text { surficial aquifer system }\end{array}$} \\
\hline \multirow{7}{*}{ Tertiary } & & & & & & \\
\hline & \multicolumn{2}{|c|}{ Upland terrace deposits } & $\begin{array}{l}\text { Brandywine } \\
\text { Gravel }\end{array}$ & $\begin{array}{l}\text { Bryn } \\
\text { Mawr } \\
\text { Gravel }\end{array}$ & $\begin{array}{l}\text { Coarse pebbles, with some sand and silt. Bryn Mawr is } \\
\text { red in color, whereas Brandywine is pink or yellow. }\end{array}$ & \\
\hline & \multicolumn{2}{|c|}{$\begin{array}{l}\text { Calvert Formation, } \\
\text { Chesapeake Group }\end{array}$} & \multicolumn{2}{|c|}{ Chesapeake Group } & Primarily gray clay, sand, and silt. & \multirow{6}{*}{$\begin{array}{l}\text { Permeable sands, where unconfined are } \\
\text { part of the surficial aquifer system }\end{array}$} \\
\hline & Nanjen & y Formation & \multirow{3}{*}{$\begin{array}{l}\text { Pamunkey } \\
\text { Group }\end{array}$} & Nanjemoy & Gray and green glauconitic sand, overlying a pink plastic & \\
\hline & $\mathrm{Ma}$ & boro Clay & & Formation & clay (the Marlboro Clay member). & \\
\hline & Aqui & Formation & & $\begin{array}{c}\text { Aquia } \\
\text { Formation }\end{array}$ & Sand, including glauconite, cemented in places by lime. & \\
\hline & \multirow{2}{*}{\multicolumn{2}{|c|}{$\begin{array}{l}\text { Brightseat Formation and } \\
\text { Monmouth Group, undivided }\end{array}$}} & \multicolumn{2}{|c|}{ Brightseat Formation } & Green and gray clayey sand and very fine glauconitic and & \\
\hline \multirow{4}{*}{ Cretaceous } & & & \multicolumn{2}{|c|}{ Monmouth Formation } & pebbles, and coarse pink quartz sand at the base. & \\
\hline & \multirow{3}{*}{$\begin{array}{l}\text { Potomac } \\
\text { Group }\end{array}$} & \multirow{2}{*}{$\begin{array}{l}\text { Clay-dominated } \\
\text { lithofacies }\end{array}$} & \multirow{3}{*}{$\begin{array}{l}\text { Potomac } \\
\text { Group }\end{array}$} & $\begin{array}{l}\text { Patapsco } \\
\text { Formation }\end{array}$ & $\begin{array}{l}\text { Commonly maroon clay at the base. Upper part is light } \\
\text { colored, with variable sand and clay. }\end{array}$ & \multirow{2}{*}{$\begin{array}{c}\text { Potomac Group } \\
\text { clay-dominated lithofacies } \\
\text { (confining to semi-confining unit) }\end{array}$} \\
\hline & & & & $\begin{array}{l}\text { Arundel } \\
\text { Formation }\end{array}$ & $\begin{array}{l}\text { Primarily dark dense clay, with iron carbonate and } \\
\text { hydrous iron oxide nodules. }\end{array}$ & \\
\hline & & $\begin{array}{c}\text { Sand-dominated } \\
\text { lithofacies }\end{array}$ & & $\begin{array}{l}\text { Patuxent } \\
\text { Formation }\end{array}$ & $\begin{array}{l}\text { Mainly medium to coarse sand, with pebbles, gravel, and } \\
\text { lenses of white or multicolored clay. }\end{array}$ & Patuxent aquifer \\
\hline
\end{tabular}

${ }^{1}$ Modified from Southworth and Denenny, 2006.

${ }^{2}$ Cooke and others, 1952; Johnston, 1964; Vroblesky and Fleck, 1991.

${ }^{3}$ This column contains hydrogeologic units used in this report. 


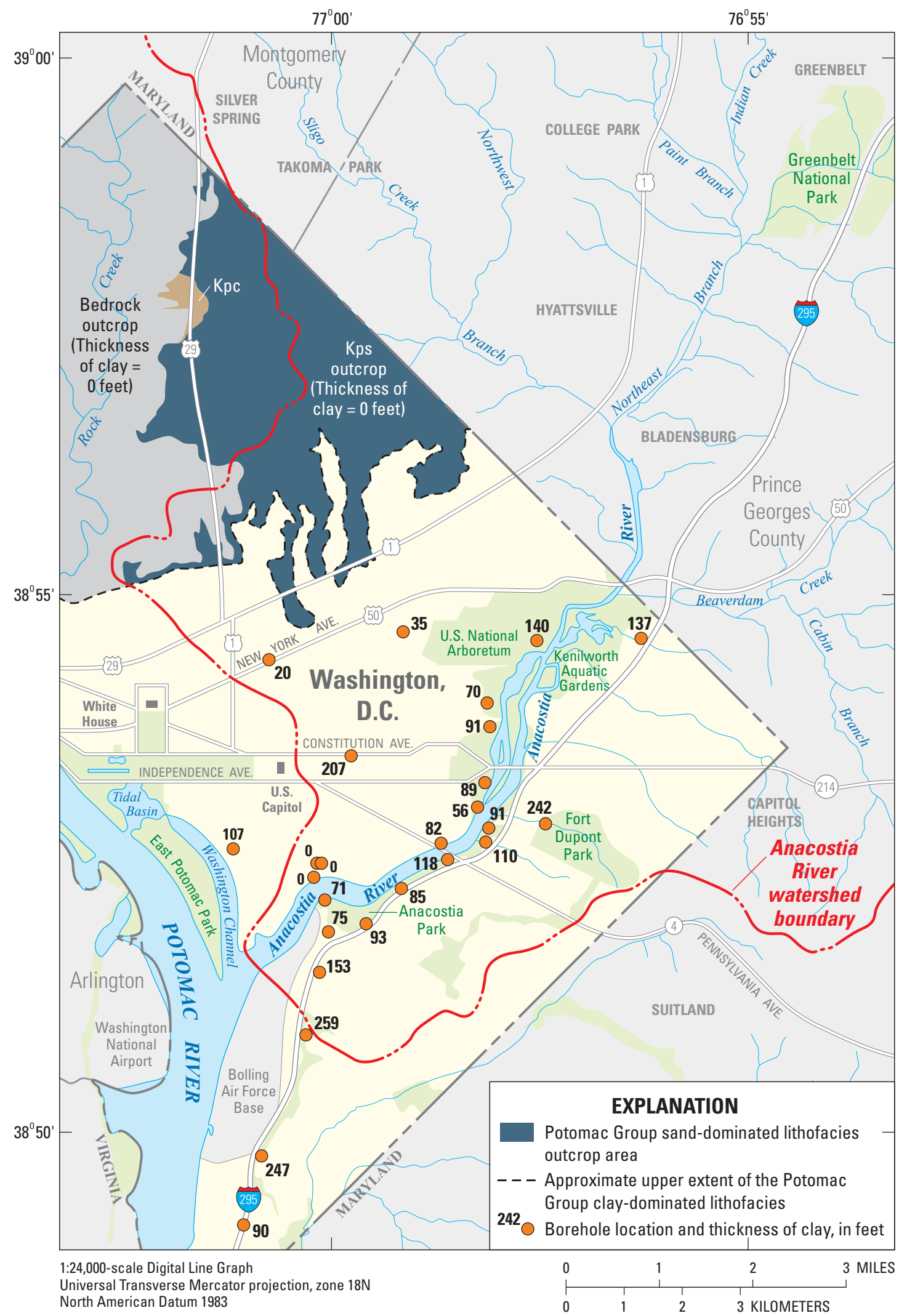

Figure 5. Distribution of the clay-dominated lithofacies of the Potomac Group (Kpc) within the tidal Anacostia River watershed, Washington, D.C. (Outcrop area of the Kps is modified from Southworth and Denenny, 2006.) 
The modern land surface in the study area reflects anthropogenic influences, as well as modern sea level. Streambed sediments in the Anacostia River in the study area are predominantly fine-grained clay and mud with abundant organic matter, as might be expected in a tidal estuary, although zones of coarser sands and gravels do occur (Velinsky and others, 1994; Washington Metropolitan Area Transit Authority, 1981). In addition, the modern river and its watershed reflect anthropogenic influences typical of urban areas (Behm and others, 2003). Natural sediments are overlain in many areas by artificial fill (Southworth and Denenny, 2006; fig. 3). The river and its streambed and riparian areas, in particular, have been altered by dredging and land reclamation; much of the modern riverfront is underlain by fill overlying buried marsh deposits (Williams, 1977).

\section{Hydrology}

The occurrence, distribution, and movement of groundwater in the Coastal Plain sediments in the study area are controlled primarily by topography, the texture and permeability (hydraulic characteristics) of geologic materials (particularly the abundance of relatively impermeable clay and silt), and human activities and alterations at or near the land surface. Groundwater in the study area occurs under both confined and unconfined conditions (Johnston, 1964). Confined groundwater occurs in the Patuxent aquifer, where it is overlain by the clay-dominated lithofacies of the Potomac Group. Groundwater in primarily permeable overlying deposits also may be locally confined in places beneath lenses or other zones of finer material. Under natural conditions, unconfined groundwater would occur in relatively permeable surficial deposits in many parts of the study area, and generally flow from upland recharge areas in the northwest and southeast toward discharge areas in and near the Anacostia River and its tributaries. The occurrence and movement of unconfined groundwater has been altered considerably, however, by dewatering, storm sewers, and other urban influences. Groundwater discharges to the Anacostia River and other streams in Washington, D.C., but the amount of groundwater discharge may be limited in areas by fine-grained riverbed sediment.

\section{Confined Aquifer}

Permeable sediments of the Potomac Group sanddominated lithofacies form a productive aquifer in the study area referred to in this report as the Patuxent aquifer, which represents an important source of water supply in southern Maryland to the south and east of Washington, D.C. (Vroblesky and Fleck, 1991; Andreasen, 2007; Drummond, 2007). Johnston (1964) reported an average yield of 80 gallons per minute $(\mathrm{gal} / \mathrm{min})$ for wells in these sediments in the vicinity of Washington, D.C.; transmissivity of the aquifer in the area is between 1,000 and 2,000 feet squared per day ( $\mathrm{ft}^{2} / \mathrm{d}$ ) (Papadopulos and others, 1974; Schnabel Engineering Associates, 1995), considerably higher than estimates for surficial aquifer sediments (table 3). The Patuxent aquifer is confined beneath the clay-dominated lithofacies of the Potomac Group in the southeastern part of the study area, but unconfined or semi-confined where it crops out or subcrops along the Fall Line to the northwest, and (possibly) in other areas if the Potomac Group clay-dominated lithofacies is missing (figs. 3, $4 A-D, 5$ ). Recharge to the confined Patuxent aquifer likely occurs primarily in the outcrop and subcrop areas, although some water may reach the aquifer as leakage through the relatively impermeable overlying sediments (Fleck and Vroblesky, 1996). Hydraulic heads in the confined Patuxent aquifer in the vicinity of the U.S. National Arboretum (observed in wells WE Ca 35 and WE Ca 36, approximately 30 and $36 \mathrm{ft}$ relative to North American Vertical Datum of 1988 [NAVD 88], respectively) are lower than in the surficial unconfined aquifer (WE Ca 37, approximately $46 \mathrm{ft}$ NAVD 88) (table 1, Appendix 3), indicating a downward gradient for groundwater flow to the Patuxent aquifer, at least in this area. Conversely, hydraulic heads in the Patuxent aquifer are higher than land surface (up to $10 \mathrm{ft}$ in places) in the vicinity of the Anacostia River in some areas (Schnabel Engineering Associates, 1995; HSI Geotrans Inc., 1998), indicating an upward hydraulic gradient and potential groundwater discharge to the river.

\section{Surficial Aquifer System}

The surficial aquifer system in the study area includes all sediments, that primarily are permeable, at or near the land surface in the watershed (Matheson and others, 1994). These include the permeable sediments of the Patuxent aquifer, where not confined beneath the Potomac Group clay-dominated lithofacies, as well as permeable overlying upland gravels and Quaternary alluvium and terrace deposits. Permeable sediments of the Brightseat Formation, Monmouth Group, and Aquia, Nanjemoy, or Calvert Formations may also form part of the surficial aquifer where they outcrop in the southeastern part of the study area. Groundwater likely occurs under primarily unconfined conditions within these sediments on the watershed scale, and groundwater-flow patterns may be approximated by the orientation of the regional water table (Matheson and others, 1994). These deposits vary considerably in texture both laterally and vertically in most areas, however, and local groundwater-flow patterns are therefore likely to be similarly complex. Groundwater within the surficial aquifer system may be perched in some areas, for example, or locally confined beneath impermeable sediments in others. Shallow groundwater flow in the heavily urbanized study area also is significantly affected by human alterations and activities at or near the land surface (D.C. Water Resources Research Center, 1992; Matheson and others, 1994), although such influences are too localized to be mapped at the regional scale. 
Natural recharge to the surficial aquifer system occurs as vertical infiltration of precipitation to the water table throughout the study area. Annual precipitation in the Washington, D.C. area ranges from 27 to 60 in., with average annual precipitation of approximately $40 \mathrm{in.} \mathrm{(National}$ Oceanographic and Atmospheric Administration, 2013): approximately 25 percent of this provides recharge to the unconfined surficial aquifer system (Cooke and others, 1952; D.C. Water Resources Research Center, 1992). Shallow groundwater is warmest in the winter (December through February) and coolest in the late spring to early summer (May through July) (fig. 6, Appendix 2), indicating a lag time between infiltration of recharge from the land surface through the unsaturated zone to the water table.

The depth to the water table varies daily, seasonally, and (or) annually within the study area, but generally occurs within 15 to $25 \mathrm{ft}$ of land surface. Near the Anacostia River, the depth to water is approximately $11 \mathrm{ft}$ below land surface at $\mathrm{WE} \mathrm{Bb} \mathrm{3,} \mathrm{and} \mathrm{about} 8 \mathrm{ft}$ below land surface at WE Ca 29. Further from the Anacostia River, water levels in well WE Ca 32 are approximately $22 \mathrm{ft}$ below land surface. Water levels in shallow wells close to the Anacostia River, such as WE Bb 3 , vary daily due to tidal fluctuations and precipitation. Other wells show seasonal fluctuations as a result of variations in precipitation and evapotranspiration (fig. 7, Appendixes 2 and 3) (D.C. Water Resources Research Center, 1992). Annual and decadal variations in the water table range from 1 to $10 \mathrm{ft}$ for the period of record for monitoring wells listed/shown in Appendix 3. Once below the water table, groundwater flows laterally and vertically downgradient from recharge areas to discharge areas such as local streams. Most parts of the watershed that are underlain by relatively permeable sediments are likely recharge areas for the surficial unconfined

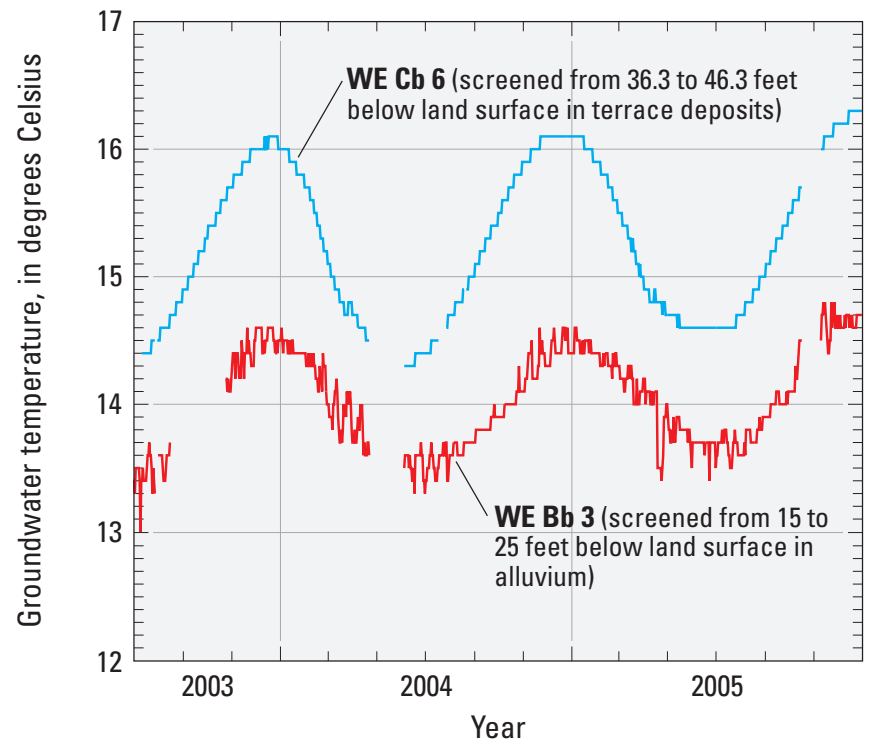

Figure 6. Groundwater temperature over time measured in selected shallow wells near the Anacostia River. aquifer; where measured, vertical flow gradients are generally downward (see, for example, fig. 7, Appendix 2).

Groundwater flow in the surficial unconfined aquifer system in the study area generally follows topographic gradients from recharge areas in uplands to discharge areas in local streams and the Anacostia River Valley. Topographic controls on unconfined groundwater flow are reflected in the regional water table shown in figure 8. Regional groundwaterflow patterns in the surficial aquifer system are similar to those observed in the early 1990s. Water levels measured in 2006 (fig. 8) are similar to those reported by Matheson and others (1994), and water-level records from shallow wells in nearby Arlington, Virginia and Prince George's County, Maryland (U.S. Geological Survey, 2009) show considerable interannual variability since 1980 , but minimal long-term trends. Groundwater in the surficial aquifer generally flows from uplands in the northwestern and southeastern parts of the study area toward a major regional discharge area in the lowlands of the Anacostia River Valley and downtown Washington, D.C., near the confluence of the Anacostia and Potomac Rivers. Northwest of the Anacostia River, groundwater flows radially from the upland near the U.S. Soldiers Home; south toward downtown and the Potomac River, east toward the Northwest Branch of the Anacostia River in Prince George's County, Maryland, and east to the tidal Anacostia River in Washington, D.C. (fig. 8) (Matheson and others, 1994). Although the study area is defined by the tidal Anacostia River watershed within Washington, D.C., groundwater flows across the surface watershed boundaries. For example, between the U.S. Capitol building and the White House, groundwater flows from within the Anacostia River watershed to the Potomac River watershed.

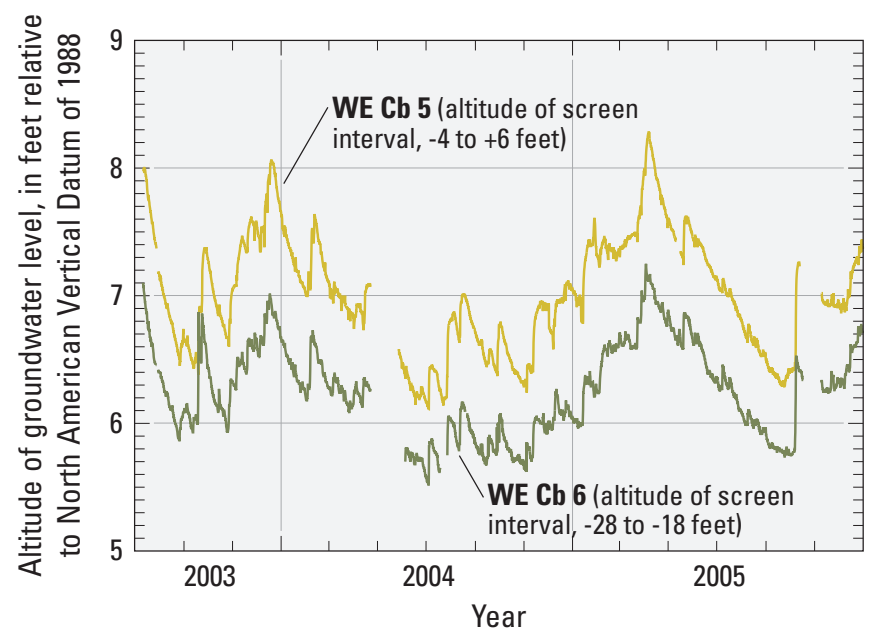

Figure 7. Groundwater levels over time at the same location but different depths within the terrace deposits. 


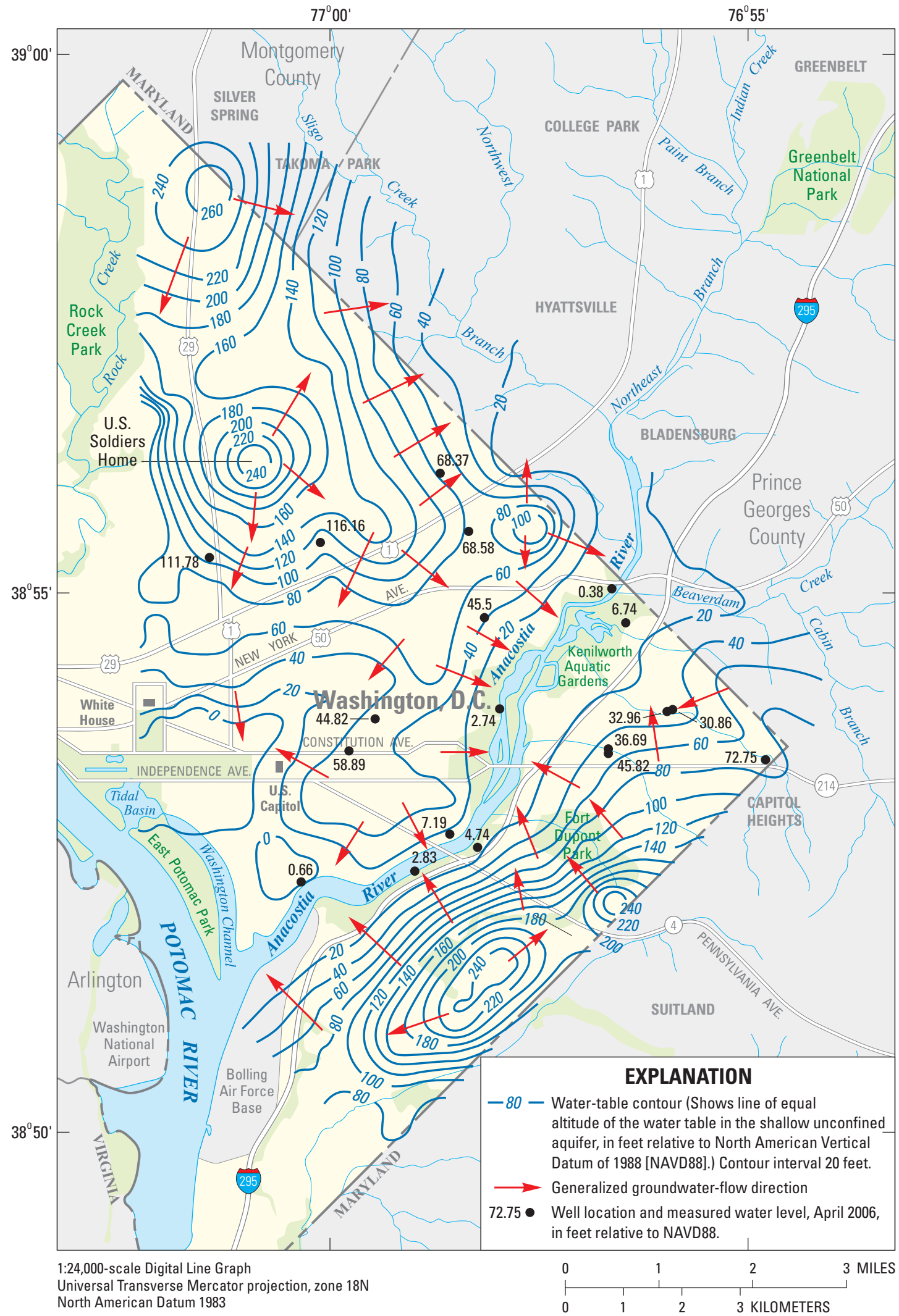

Figure 8. Estimated orientation of the regional water table, and generalized groundwater-flow directions in the surficial aquifer, tidal Anacostia River watershed, Washington, D.C., and vicinity (modified from Matheson and others, 1994, on the basis of groundwater-level measurements, April 2006). 
General groundwater occurrence, distribution, and flow patterns in the surficial aquifer apparent from the orientation of the regional water table are likely complicated locally by variable hydrogeologic conditions. Groundwater may be unconfined in surficial aquifers at the regional scale, but locally confined in places by overlying clay lenses or other zones of relatively impermeable sediments. Flow patterns also are affected by local variability in sediments that is difficult to map regionally. Lateral groundwater flow is likely focused in relatively permeable sediments (such as sand or gravel); flow through less permeable silt or clay is often more vertical and much slower. Also, perched groundwater above the regional water table may occur in permeable sediments overlying relatively impermeable clay lenses or other deposits (D.C. Water Resources Research Center, 1992).

Groundwater flow in the surficial aquifer system of the study area is also significantly affected by human activities and alterations common to urban areas (D.C. Water Resources Research Center, 1992; Matheson and others, 1994). The water table in parts of the study area is artificially lowered for construction or to prevent seepage and flooding of basements, tunnels, or other buried infrastructure. Conversely, groundwater levels around some buildings must be artificially raised to prevent deterioration of wooden foundation pilings (D.C. Water Resources Research Center, 1992). This manipulation of the water table alters local flow gradients, and dewatering may also cause irreversible sediment compaction and land subsidence. Many natural streams in the watershed have been completely filled for development (fig. 2), creating high-permeability zones of preferential groundwater flow. The former course of Tiber Creek (fig. 2), for example, remains apparent as a zone of focused groundwater flow in the regional water table (fig. 8) (Matheson and others, 1994). Pipelines, sewers, tunnels, and other buried infrastructure may also divert local groundwater flow and serve as discharge zones (Matheson and others, 1994).

\section{Groundwater-Surface-Water Interaction}

Streams and tidal estuaries (such as the tidal Anacostia River) are discharge areas for most groundwater in the lower Anacostia River watershed study area. As in most humid areas, groundwater levels in the study area are generally higher than water levels in adjacent streams, indicating groundwater discharge to streams (Fleck and Vroblesky, 1996) (fig. 8, Appendix 2). Although local groundwater-flow directions may be altered by human activities (such as dewatering) in some areas, groundwater in the surficial aquifer generally flows from upland recharge areas to discharge areas in streams and other surface waters (fig. 8). Unlike in upland recharge areas where vertical gradients reflect downward recharge to the surficial aquifer (fig.7, Appendix 2,), vertical gradients are lower or upward in discharge areas near the Anacostia River, and groundwater may flow more laterally (fig. 9) or upward beneath the river. Sediments in the surficial aquifer are coarse and permeable in some areas near the river (Appendix 1), and variations in groundwater levels in discharge areas near the Anacostia River are controlled mainly by the tidal fluctuations in the river (fig. 9), rather than seasonally variable infiltration rates as in upland recharge areas (fig. 7, Appendix 2).

Groundwater discharge to the Anacostia River and tributaries may occur over broad areas of the streambed, but is likely focused in areas of particularly permeable sediments. Direct groundwater seepage to the Anacostia River has been documented (Chadwick and others, 2001; Matrix Environmental and Geotechnical Services, 2003), and tidal fluctuations in groundwater levels near tidal waters (fig. 9) may indicate a connection between groundwater and surface waters in the study area. Such connections are enhanced by storm sewers, which may serve as direct conduits for shallow groundwater movement to streams and estuaries. The District of Columbia Water and Sewer Authority (Greeley and Hansen, 2009, table ES-2) estimated that from May 2003 to May 2004 in Washington, D.C., 58 million gallons per day (Mgal/d) of groundwater infiltrated into sewers, and $16 \mathrm{Mgal} / \mathrm{d}$ of groundwater were pumped from sumps into sewers. This estimated $74 \mathrm{Mgal} / \mathrm{d}$ of groundwater ultimately discharged to surface waters during the 1-year period. Greeley and Hansen (2009, table ES-2) also estimated that 47, 52, or $64 \mathrm{Mgal} / \mathrm{d}$ of groundwater (infiltration and pumpage) flows into sewers during dry, average, and wet years, respectively.

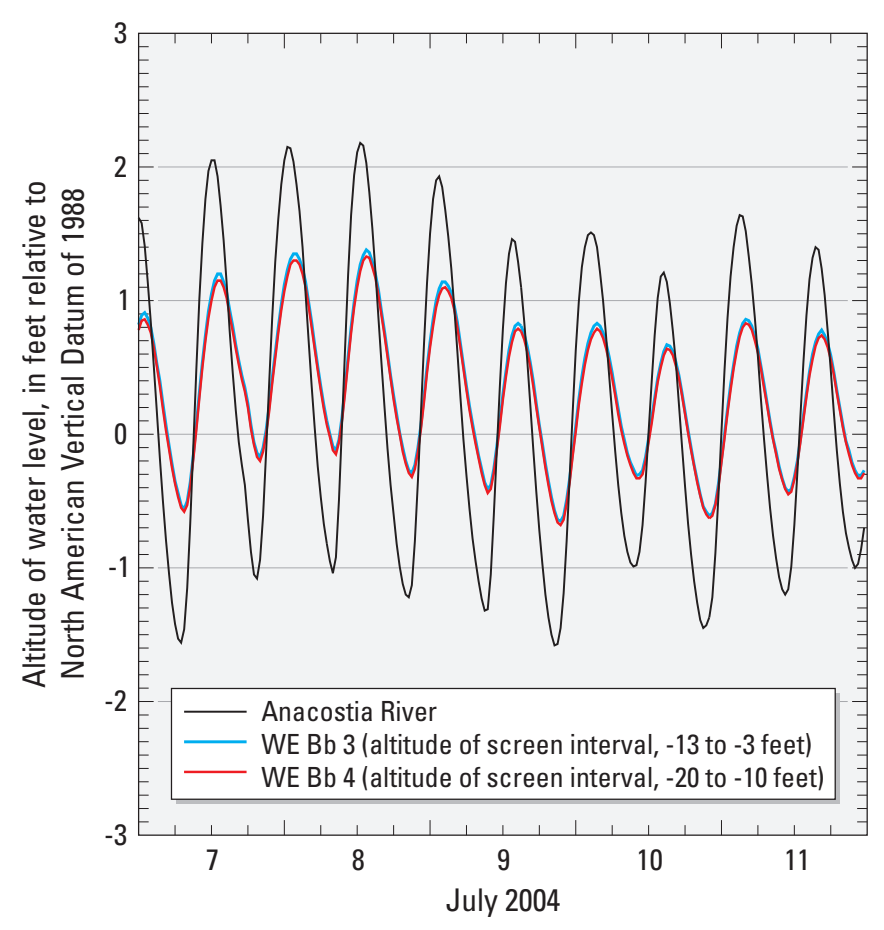

Figure 9. Tidal fluctuations in water levels in the Anacostia River (U.S. Geological Survey station number 01651750) and in nearby shallow groundwater wells WE Bb 3 and WE Bb 4, July 2004. 
Locally in some places, the hydraulic heads in the confined Patuxent aquifer are higher than the level of the Anacostia River (up to 20-30 ft) (Matheson and others, 1994; Schnabel Engineering Associates, 1995; HSI Geotrans Inc., 1998). Discharge from the Patuxent aquifer to the Anacostia River is probably limited by the intervening clays of the Potomac Group (Schnabel Engineering Associates, 1995), but could be occurring in areas, such as at borings AX Ac 2, SAS001 , and SAS-103, where the clayey sediments are missing as a result of erosion or other natural geological processes.

\section{Geochemistry and Groundwater Quality}

Groundwater in the tidal Anacostia River watershed is affected by natural hydrogeologic conditions and a variety of chemicals from different urban sources. Surficial sediments in the study area are highly variable, ranging from sand with little organic matter in fluvial terrace deposits and Potomac Group sand subcrop areas, to organic-rich silt and clay in alluvium near the river (fig. 3). Factors such as the amount of sand, silt, clay, or organic matter in soils and aquifer sediments influence natural water chemistry and the redox state of the aquifer, as well as the ease with which contaminants may enter and travel through groundwater. Under natural conditions in shallow Coastal Plain sediments, dissolved ions in groundwater are derived from precipitation and natural mineral sources (such as silicates and carbonates), and groundwater is typically dilute (Hamilton and others, 1993). Nitrate concentrations are generally less than 0.4 milligram per liter $(\mathrm{mg} / \mathrm{L})$ and chloride concentrations are generally less than $6 \mathrm{mg} / \mathrm{L}$ (Hamilton and others, 1993). Human sources of chemical contaminants in urban areas include road salting (Williams and others, 1999), fertilizer and pesticide applications, and leaks from sewer lines, industrial activities, and chemical storage and transport facilities. Sources of chemical contamination may be diffuse and widespread, such as infiltration of water near roads, or they may occur in localized plumes from spills and leaks.

Reduction/oxidation processes affect shallow groundwater quality in Washington, D.C. Where soils and surficial aquifer sediments are sandy with little organic matter, groundwater is typically unconfined, oxic (dissolved oxygen greater than $1 \mathrm{mg} / \mathrm{L}$ ), and contains low concentrations of iron and manganese. Such aquifers are particularly vulnerable to surficial contamination, because groundwater moves easily through the permeable sediments, and sorption sites for solutes are limited. Also, some organic contaminants are more persistent in oxic groundwater than in areas with little dissolved oxygen (Zogorski and others, 2006). In addition to organic contaminants, groundwater in sandy unconfined aquifers often contains elevated concentrations of nitrate and chloride from leaky sewers, fertilizers, or road salt (Williams and others, 1999).
Groundwater in areas with fine-grained organic-rich soil and sediments is less vulnerable to contamination from surficial sources. Infiltration in such areas is limited by the low-permeability materials. Also, sorption sites for chemicals on clay and organic particles are more common, and water moves more slowly, allowing more time for sorption or biological degradation of many contaminants. Groundwater in such fine-grained sediments generally contains little dissolved oxygen (less than $1 \mathrm{mg} / \mathrm{L}$ ). In these anoxic conditions, dissolved nitrogen generally occurs in ammonia or organic forms and any nitrate present is reduced to nitrogen gas. Conversely, concentrations of iron and manganese, which occur naturally in aquifer sediments and are more soluble and therefore mobile under reducing conditions, are commonly elevated in anoxic groundwater. Denver and others $(2014$, p. 29) provide a description of redox processes that occur in groundwater systems. The occurrence of nitrate and iron together in a water sample may indicate mixing of groundwater from zones of different redox conditions as iron will only dissolve in oxic groundwater where $\mathrm{pH}$ is particularly low (Hem, 1992). Arsenic and other metals are also more mobile in groundwater under anoxic conditions. Therefore, metals, such as arsenic, can occur naturally in the aquifer materials and become mobilized by redox processes, or they can be the result of anthropogenic sources.

\section{Major-Ion Geochemistry}

Groundwater in sampled wells in the study area is chemically variable, but predominantly anoxic, and an ironor calcium-bicarbonate type (Klohe and Debrewer, 2007) (fig. 10). Groundwater samples were collected from 17 wells screened in three geologic settings: Holocene alluvium (including overlying dredge spoils) along the Anacostia River and tributaries (6 wells); Upper Tertiary and younger terrace deposits (4 wells); and unconfined and confined parts of the Potomac Group (7 wells) (table 1). The predominantly anoxic conditions in groundwater are shown by the common occurrence of iron and manganese at high concentrations, and concentrations of nitrate that are below detection. Iron concentrations exceeded $15,000 \mathrm{mg} / \mathrm{L}$ in most of the groundwater samples from the Holocene alluvium (table 5), and are above the District of Columbia groundwater standard of $300 \mu \mathrm{g} / \mathrm{L}$ (District of Columbia, 1993). Low concentrations of sulfate in groundwater within the alluvium indicate that much of the groundwater with high iron concentrations has been chemically altered by sulfate reduction. Under such anoxic conditions, dissolved oxygen should be below detection in groundwater. The occurrence of detectable dissolved oxygen in samples from the alluvium where anoxic conditions are indicated may be the result of mixing of water from anoxic and oxic zones in the aquifer, or from the introduction of air during sampling (table 5). 


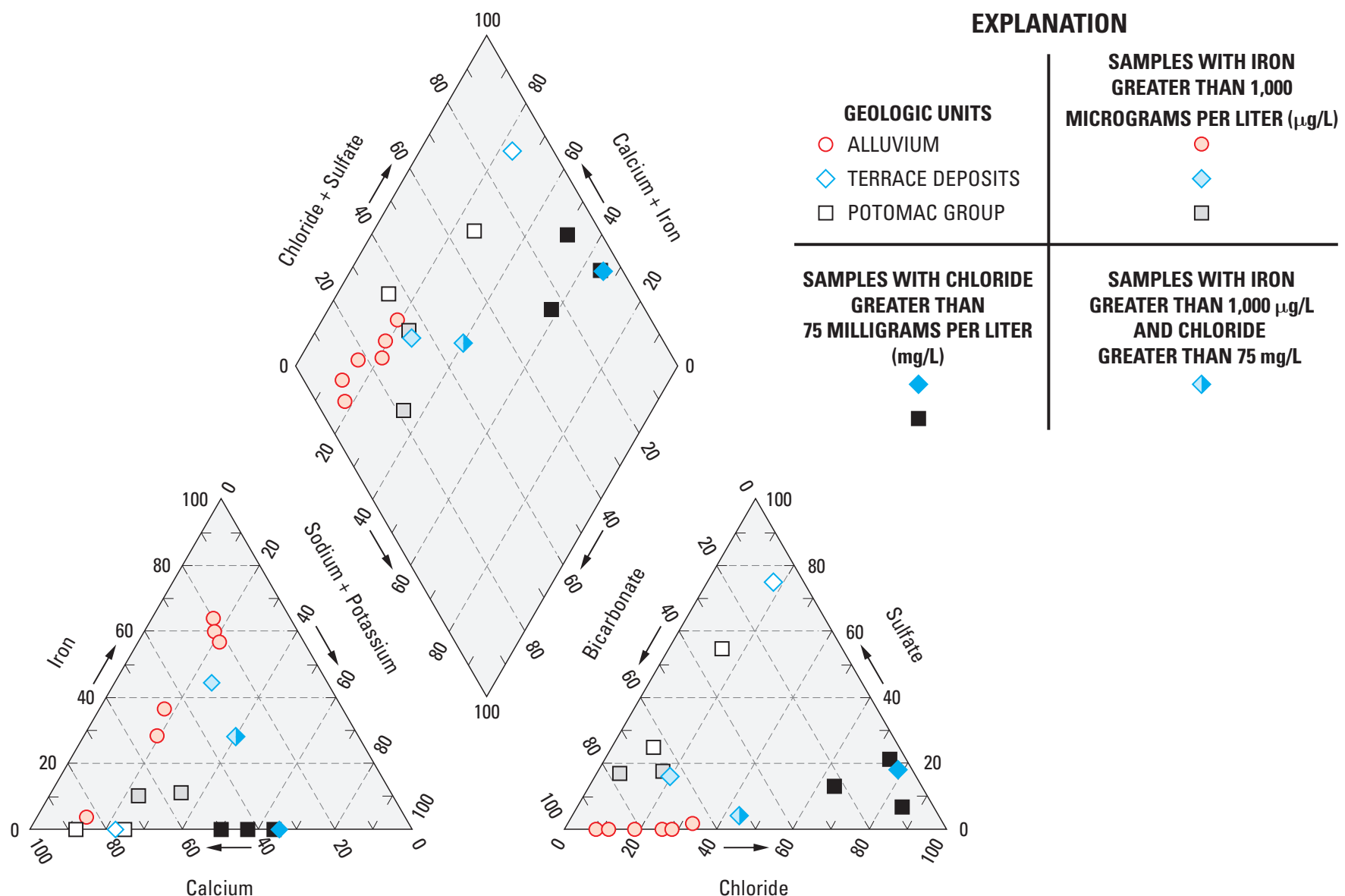

Percentage of total milliequivalents per liter

Figure 10. General water chemistry by geologic unit for groundwater samples collected from the Anacostia River watershed in Washington, D.C., September-December 2005. Percentages of particular ions increase in the direction of the arrow on each axis (modified from Klohe and Debrewer, 2007).

Groundwater from terrace deposits and the Potomac Group is more commonly oxic and more vulnerable to contamination from surficial sources than groundwater in the alluvium. Nitrate concentrations above $1 \mathrm{mg} / \mathrm{L}$ indicate the presence of human nitrogen sources; nitrate was above the District of Columbia groundwater standard of $10 \mathrm{mg} / \mathrm{L}$ in well WW Bc 8 (11.2 mg/L) (table 5). Concentrations of chloride in five samples (from wells WE Ca 32, WE Ca 33, WE Cc 3, WW Bc 8, and WW Bc 9) exceeded 75 mg/L (fig. 10, table 5), indicating significant infiltration of salty water, such as from road salting (Williams and others, 1999). Chloride in well WE Ca $32(257 \mathrm{mg} / \mathrm{L})$ was above the District of Columbia groundwater standard of $250 \mathrm{mg} / \mathrm{L}$. Iron concentrations were generally low in these oxic groundwater samples, although other samples with dissolved oxygen below detection had elevated concentrations of iron and manganese (generally found in anoxic groundwater) (table 5). Concentrations of both nitrate and iron were relatively high in well WE Cc 3, indicating a mixture of water from oxic and anoxic zones in the aquifer (table 5). Some oxic groundwater also contains manganese at concentrations above the District of Columbia groundwater standard (table 5). Although high concentrations of manganese are more common in anoxic water, manganese is more stable than iron in oxic water and may occur at high concentrations (Hem, 1992).

\section{Human Impacts on Groundwater Quality}

Anthropogenic influences on groundwater quality in the tidal Anacostia River watershed are apparent from the occurrence and distribution of selected inorganic and organic ions and compounds. Chloride and nitrate occur naturally in the environment, but elevated concentrations observed in some areas of the watershed are indicative of human sources, such as fertilizer applications, leaking sewer lines, or road salt. Many organic compounds (such as pesticides and VOCs) have no natural sources, and their occurrence in groundwater is clearly related to potential human sources typical of the heavily urbanized watershed. 
Table 5. Summary of selected water-quality constituents in groundwater in different geologic settings in the Anacostia River watershed within Washington, D.C., 2005.

$[\mu \mathrm{S} / \mathrm{cm}$, microsiemens per centimeter at 25 degrees Celsius; $\mathrm{mg} / \mathrm{L}$, milligrams per liter, $\mu \mathrm{g} / \mathrm{L}$, micrograms per liter; $\mathrm{N}$, nitrogen; --, not measured; <, less than; E, estimated]

\begin{tabular}{|c|c|c|c|c|c|c|c|c|c|c|c|}
\hline $\begin{array}{c}\text { Well } \\
\text { number }\end{array}$ & 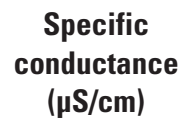 & pH & $\begin{array}{c}\text { Dissolved } \\
\text { oxygen } \\
\text { (mg/L) }\end{array}$ & $\begin{array}{c}\text { Chloride } \\
\text { mg/L }\end{array}$ & $\begin{array}{l}\text { Iron } \\
(\mu \mathrm{g} / \mathrm{L})\end{array}$ & $\begin{array}{c}\text { Manganese } \\
(\mu \mathrm{g} / \mathrm{L})\end{array}$ & $\begin{array}{c}\text { Nitrate } \\
\text { (mg/L } \\
\text { as N) }\end{array}$ & $\begin{array}{c}\text { Ammonia } \\
\text { (mg/L } \\
\text { as } \mathrm{N})\end{array}$ & $\begin{array}{c}\text { Phosphorus } \\
\text { (mg/L) }\end{array}$ & $\begin{array}{l}\text { Sulfate } \\
\text { (mg/L) }\end{array}$ & $\begin{array}{c}\text { Arsenic } \\
(\mu \mathrm{g} / \mathrm{L})\end{array}$ \\
\hline \multicolumn{12}{|c|}{ Alluvium } \\
\hline AC Aa 1 & 291 & 6.7 & 3.1 & 9.39 & 22,500 & 63.1 & $<0.06$ & 3.81 & 0.43 & $<2$ & 39.9 \\
\hline WE Bb 3 & 363 & 5.9 & 1 & 23 & 54,400 & 2,330 & $<0.06$ & 4.38 & 0.49 & $<2$ & 0.38 \\
\hline WE Bb 4 & 279 & 6 & 1.6 & 24.2 & 36,900 & 1,600 & $<0.06$ & 1.76 & 0.43 & $<2$ & 0.4 \\
\hline WE Ca 34 & 696 & 7.3 & $<1$ & 27.6 & 7,930 & 643 & $<0.06$ & 3.27 & 0.2 & E.1 & 2.1 \\
\hline WE Cb 11 & 355 & 6.2 & -- & 37 & 17,200 & 5,890 & $<0.06$ & 0.15 & $<0.04$ & 2.7 & 0.79 \\
\hline \multicolumn{12}{|c|}{ Terrace deposits } \\
\hline WE Ca 32 & 1,100 & 5.6 & 5.8 & 257 & 13 & 2.8 & 7.74 & $<0.10$ & $<0.04$ & 79.7 & 0.43 \\
\hline \multicolumn{12}{|c|}{ Potomac Group } \\
\hline WE Ba 9 & 649 & 6.2 & $<1$ & 24.2 & $<6$ & 554 & 1.36 & 0.4 & $<0.04$ & 91.1 & E0.1 \\
\hline WE Ba 10 & 261 & 5.4 & $<1$ & 11.4 & $<6$ & 176 & 1.15 & E0.07 & $<0.04$ & 61.1 & E.06 \\
\hline WE Cb 8 & 151 & 6.8 & -- & 2.91 & 3,070 & 189 & $<0.06$ & E0.08 & 0.29 & 11.8 & E0.11 \\
\hline WE Cb 12 & 164 & 5.8 & $<1$ & 9.14 & 3,060 & 1,400 & $<0.06$ & 0.15 & $<0.04$ & 12.5 & 0.3 \\
\hline WE Cc 3 & 854 & 5.9 & 2 & 170 & 815 & 255 & 3.03 & 0.16 & $<0.04$ & 46.7 & 0.12 \\
\hline WW Bc 8 & 482 & 5 & 1.7 & 97.4 & 8 & 480 & 11.2 & 0.56 & $<0.04$ & 11.4 & 0.28 \\
\hline WW Bc 9 & 371 & 4.8 & -- & 77.3 & 7 & 296 & 2.92 & E0.07 & $<0.04$ & 30.6 & 0.2 \\
\hline
\end{tabular}

Organic contaminants, including VOCs and SVOCs, diesel-range and gasoline-range organics, and pesticides and their degradants, were detected in shallow groundwater in the study area. Although only a few of the more than 200 anthropogenic organic compounds for which samples were analyzed were detected in groundwater, at least 1 such compound was detectable in samples from 15 of the 17 wells (table 6) (Klohe and Debrewer, 2007). The most commonly detected compounds were solvents, pesticides, and pesticide degradants (tables 6, 7). Concentrations of detected compounds were compared to District of Columbia groundwater standards, U.S. Environmental Protection Agency Maximum Contaminant Levels (MCLs) and RiskBased Concentrations (RBCs) (Klohe and Debrewer, 2007). Concentrations were generally well below established standards and many were detected below their laboratory reporting levels. One exception is tetrachloroethene, which was measured at $68 \mu \mathrm{g} / \mathrm{L}$ in water from well WW Bc 8; the
District of Columbia groundwater standard is $5 \mu \mathrm{g} / \mathrm{L}$ for this compound. Several of the detected pesticide and degradant compounds (dieldrin, heptachlor epoxide, p,p'-DDE, and chlordane) have been banned since at least the 1980s (Klohe and Debrewer, 2007); their presence in groundwater is related to their persistence in the environment and the slow traveltime of groundwater.

The distribution of organic contaminants in groundwater is related to the local hydrogeologic setting and natural aquifer geochemistry, as well as the distribution of potential sources. The frequency of detection and variability in types of organic contaminants were generally greater in wells located in areas with high density residential, commercial, or municipal development (particularly in wells WE Ca 32, WE Ca 33, and WW Bc 8), for example, than in settings like neighborhoods and municipal parks, where most of the other sampled wells are located (table 6). 
Table 6. Distribution of organic compounds by type in groundwater samples from different geologic settings in the Anacostia River watershed within Washington, D.C., 2005.

[Shading indicates compounds were detected; number indicates number of individual compounds, where reported.]

\begin{tabular}{|c|c|c|c|c|c|c|c|c|c|}
\hline Well number & $\begin{array}{c}\text { Gasoline } \\
\text { hydrocarbons }\end{array}$ & $\begin{array}{c}\text { Gasoline } \\
\text { oxygenates }\end{array}$ & Solvents & $\begin{array}{c}\text { Pesticides or } \\
\text { degradates }\end{array}$ & Phenols & Phthalates & $\begin{array}{c}\text { Diesel } \\
\text { range } \\
\text { organics }\end{array}$ & $\begin{array}{c}\text { Gasoline } \\
\text { range } \\
\text { organics }\end{array}$ & $\begin{array}{c}\text { Oil } \\
\text { and } \\
\text { grease }\end{array}$ \\
\hline \multicolumn{10}{|c|}{ Alluvium } \\
\hline \multicolumn{10}{|l|}{$\mathrm{AC}$ Aa 1} \\
\hline WE Bb 3 & & & 1 & 1 & & & & & \\
\hline \multicolumn{10}{|l|}{ WE Ca 34} \\
\hline \multicolumn{10}{|l|}{ WE Cb 11} \\
\hline \multicolumn{10}{|c|}{ Terrace deposits } \\
\hline WE Ca 32 & & & 1 & 7 & & & & & \\
\hline \multicolumn{10}{|c|}{ Potomac Group } \\
\hline WE Ba 9 & & & & 1 & & & & & \\
\hline \multicolumn{10}{|l|}{ WE Ba 10} \\
\hline WE Cb 8 & & & & 1 & & & & & \\
\hline WE Cb 12 & & & 1 & & & & & & \\
\hline WE Cc 3 & & & & 2 & & & & & \\
\hline WW Bc 8 & & & 6 & & & & & & \\
\hline WW Bc 9 & & & 1 & 3 & & & & & \\
\hline
\end{tabular}

\section{Potomac Group}

Groundwater in the Potomac Group occurs in the sanddominated lithofacies (Patuxent aquifer), as well as relatively coarse sediments in the overlying Potomac Group claydominated lithofacies. Where these sediments crop out in parts of the study area (figs. 3, 4A, 4B), groundwater is vulnerable to contamination from the land surface or from near-surface leaks and spills. Nitrate and chloride concentrations in five of the seven Potomac Group wells indicate oxic groundwater and human impacts, such as fertilizer applications, leaky sewers, or road salting (table 5). Organic contaminants were present in groundwater in all but one of these wells (WE Ba 10) (table 6), which contained only slightly elevated concentrations of nitrate and chloride (table 5). Most of the observed concentrations of organic contaminants were relatively low, and sources are apparently diffuse and at or near the land surface. Water from well WW Bc 8 was particularly contaminated with solvents and hydrocarbon compounds that may be associated with an unidentified leak in an underground tank.

Organic contaminants also were present in samples from selected Potomac Group wells with relatively high iron concentrations and, therefore, anoxic groundwater (tables 5, 6). Concentrations of both nitrate (indicative of oxic aquifer conditions) and iron (indicative of anoxic conditions) were relatively high in samples from well WE Cc 3 (table 5), indicating that this well may be screened across two geochemical environments in the aquifer. The particularly high chloride concentration in water from this well indicates infiltration from road surfaces. Water from well WE $\mathrm{Cb} 8$, which is $265 \mathrm{ft}$ deep and screened in the confined part of the Patuxent aquifer, showed characteristics of natural groundwater quality (table 5), but also had a very low concentration of a pesticide used for weed control (metsulfuron methyl). This contamination may be related to a broken well cap that allowed water from the surface to enter the well. 
Table 7. Summary of organic compounds detected in groundwater samples from 17 wells in the Anacostia River watershed within Washington, D.C., September-December 2005 (modified from tables 7 and 8 in Klohe and Debrewer, 2007).

[1, indicates number of compounds detected; *, indicates one or more detections below reporting level; CEAT, 2-cloro-6-ethylamino-s-triazine; CIAT, 2-chloro-4-isopropylamino-6-amino-s-triazine; OIET, 2-Hydroxy-4isopropylamino-6-ethylamino-s-triazine]

\begin{tabular}{|c|c|}
\hline Volatile organic compounds & Semivolatile organic compounds \\
\hline 1,2,Dichloroethane $(1 *)$ & bis(2-Ethylhexyl) phthalate $\left(1^{*}\right)$ \\
\hline Dichloromethane $\left(4^{*}\right)$ & Phenols, total recoverable $(2 *)$ \\
\hline Isopropylbenzene (1) & Pesticides and degradates \\
\hline methyl tert-butyl ether $(2 *)$ & Atrazine (1) \\
\hline$n$-Butylbenzene (1) & Bromacil $(1 *)$ \\
\hline sec-Butylbenzene (1) & $\operatorname{CEAT}(1 *)$ \\
\hline tert-Butylbenzene $(1 *)$ & $\operatorname{CIAT}(2 *)$ \\
\hline Tetrachloroethene (1) & Dieldrin (2) \\
\hline Toluene $(1 *)$ & Heptachlor epoxide (2) \\
\hline Trichloroethene (1) & Imidacloprid (1) \\
\hline Trichloromethane $\left(5^{*}\right)$ & Metsulfuron (1) \\
\hline $\begin{array}{c}\text { Diesel-range/ } \\
\text { gasoline-range organics }\end{array}$ & $\operatorname{OIET}\left(1^{*}\right)$ \\
\hline Diesel-range organics $\left(6^{*}\right)$ & p,p'-DDE (1) \\
\hline Gasoline-range organics $\left(5^{*}\right)$ & Chlordane, technical mix (1) \\
\hline Oil and Grease $(2 *)$ & Tebuthiuron (1) \\
\hline
\end{tabular}

\section{Terrace Deposits}

The terrace deposits include fining-upward sequences of gravel, sand, silt, and clay and form the land surface over much of Washington, D.C. in the Anacostia River Valley (fig. 3). Much of the area covered by sandy deposits near the land surface is vulnerable to contamination. Water quality in these deposits is quite variable, ranging from apparently uncontaminated (in well WE $\mathrm{Cb} 6$ ) to highly contaminated (in wells WE Ca 32 and WE Ca 33) (tables 5, 6). This variability is related to the heterogeneous hydrogeologic conditions in these deposits, as well as the variability in urban sources of contamination. Groundwater in well WE Cb 6 is confined, and the low specific conductance and chloride concentrations indicate minimal (if any) anthropogenic impacts (table 5). In contrast, specific conductance and chloride concentrations were considerably higher in groundwater from wells WE Ca 32 and WE Ca 33. Groundwater from well WE Ca 32 also contained nitrate and sulfate at relatively high concentrations, indicative of possible sewage contamination, as well as a variety of pesticides (mostly insecticides), and hydrocarbonrelated organic compounds. Contaminants in well WE Ca 33 were generally petroleum-related compounds indicative of a leak or spill. Water from well WE Ca 33 was anoxic (with a relatively high dissolved-iron concentration), possibly due to degradation of petroleum-related compounds and related consumption of dissolved oxygen and nitrate in the water.

\section{Alluvium}

Alluvial sediments (and fine-grained fill dredged from the river channel and placed over buried marsh deposits) are located beneath and adjacent to the Anacostia River and its tributaries (fig. 3). These sediments typically contain abundant organic matter, and groundwater is therefore generally anoxic, with very high concentrations of dissolved iron and little detectable sulfate or nitrate (table 5). Concentrations of ammonia, organic nitrogen, and arsenic also are generally higher in groundwater in the alluvium than in most samples from other hydrogeologic settings; these compounds could be derived from natural sources such as buried marshes. The highest arsenic concentration, $39.9 \mu \mathrm{g} / \mathrm{L}$, was measured in groundwater from well AC Aa 1 near Poplar Point, where arsenic contamination in soil has been documented (Ridolfi Inc., 2005). Chloride concentrations were slightly elevated in samples from all six alluvium wells, but not as high as might be expected from significant infiltrations of salty road runoff (table 5). Organic chemicals detected in these samples could be indicative of above- or below-ground releases, although the relatively fine-grained, organicrich alluvium is not particularly conducive to contaminant transport. As a result, concentrations and detection frequencies of organic contaminants were generally lower in water samples from these areas (areas labeled as Qa on fig. 3) than in many samples from other parts of the study area, and may be indicative of diffuse sources (table 6). Because of the proximity of the wells screened in the alluvium to the Anacostia River (fig. 2) and the predominant hydraulic gradient of the water table toward the river (fig. 8), however, dissolved chemicals in alluvial sediments may be particularly relevant to surface-water quality. 


\section{Comparison of Groundwater Quality in 2002 and 2005}

Data presented in Miller and Klohe (2003) and Klohe and Debrewer (2007) indicate that groundwater quality in sampled wells has changed minimally over recent years, as would be expected in light of the typically slow movement of groundwater. Temporal comparisons are complicated by variable sample collection and analysis methods. Specific conductance and $\mathrm{pH}$, however, varied by only 2 to 15 percent between 2002 and 2005 in samples from five wells for which data are available. Similarly, concentrations of phosphorus and ammonia plus organic nitrogen in samples from these wells in 2002 were generally within $0.3 \mathrm{mg} / \mathrm{L}$ of those measured in 2005. Concentrations of selected dissolved trace metals (measured in filtered samples) in 2005 were generally less than or equal to the whole-water concentrations (measured in unfiltered samples) in 2002. Trichloromethane (chloroform) was the only anthropogenic organic compound detected above a common level in the same well in 2002 and 2005; concentrations in well WE Cb 5 were 5.7 and $0.95 \mu \mathrm{g} / \mathrm{L}$ (estimated) in 2002 and 2005, respectively.

\section{Summary and Conclusions}

Hydrology and groundwater quality in the tidal Anacostia River watershed in Washington, D.C. are affected by multiple natural and human influences. Although sources of some ions or compounds to the land surface or groundwater may be natural, other compounds (such as pesticides and volatile organic compounds, or VOCs) are exclusively anthropogenic, and may be derived from many different human activities in the heavily urbanized watershed. The distribution of these compounds in groundwater and streams in the study area is related to spatially variable hydrogeologic and geochemical conditions that control their movement and persistence in the environment, as well as the distribution and magnitude of sources. Hydrologic, geochemical, and geologic data were collected over a multi-year period and interpreted along with similar existing information to improve understanding of the hydrogeology and groundwater quality in the tidal Anacostia River watershed.

The tidal Anacostia River watershed is underlain by a wedge of heterogeneous unconsolidated sediment that forms a series of aquifers and confining units overlying a sloping bedrock surface. The Patuxent aquifer, the oldest and lowermost unconsolidated unit, crops out and subcrops in the northwestern part of the study area along the Fall Line and dips to the southeast. This aquifer is confined to the southeast by the overlying Potomac Group clay-dominated lithofacies (where present), which is relatively thick and likely isolates the confined Patuxent aquifer from the Anacostia River. Above the Potomac Group sediments are younger Upper Cretaceous and Tertiary marine deposits, coarse upland deposits, and alluvial and terrace deposits. Surficial and near-surface sediments are particularly variable and difficult to correlate at the watershed scale, and surficial geology has been further complicated by more than 200 years of human alterations such as dredging and filling. Permeable surficial sediments form an extensive surficial aquifer system, although locally variable hydrologic and geochemical conditions in the system reflect the locally variable geology. The interbedded permeable and less permeable sediments in the surficial aquifer, for example, may cause local perched aquifers or semi-confined conditions.

Water levels and groundwater flow in the surficial aquifer system are controlled primarily by topography and the permeability of the sediments. Recharge to the surficial aquifer system occurs through infiltration of precipitation, as well as possible artificial sources such as underground water or sewer pipes. Unconfined groundwater generally flows from upland recharge areas in the northwest and southeast toward discharge areas in and near the Anacostia River and its tributaries. Discharge to the Anacostia River may be limited in areas by fine-grained riverbed sediment. Recharge to the Patuxent aquifer occurs primarily in the outcrop and subcrop areas, or as leakage from the less permeable overlying clays. Beneath the Anacostia River, the hydraulic heads in the confined Patuxent aquifer are higher than land surface, and discharge from this aquifer to the Anacostia River probably occurs where sediments of the Potomac Group clay-dominated lithofacies are absent.

Chemical data collected from 17 wells were analyzed for selected major ions, trace elements, nutrients, pesticides and pesticide degradants, VOCs and semi-volatile organic compounds, phenols, polychlorinated biphenyls, and oil and grease. Of over 200 chemicals included in these analyses, only 28 anthropogenic organic compounds were detected in groundwater from 15 of the 17 sampled wells, and over half of these compounds were only detected once. Only one organic compound in one sample, tetrachloroethene, was detected at a concentration above an existing health standard. Arsenic was detected at generally low levels; however, the concentration in one sample exceeded the U.S. Environmental Protection Agency Maximum Contaminant Level of 10 micrograms per liter. In addition, concentrations of iron and manganese were detected in many wells at levels above regulatory criteria due to reducing conditions in aquifer sediments. 
The distribution of groundwater chemistry and contaminants in groundwater of the Anacostia River watershed is related to local hydrogeology and natural aquifer geochemistry, as well as land use and the associated distribution of potential sources. Nitrate and chloride concentrations in some areas likely exceed natural levels, and anthropogenic organic compounds were widely detected in shallow groundwater (particularly in the terrace deposits and Potomac Group). Groundwater in unconfined parts of the Potomac Group is primarily oxic, and concentrations of nitrate and chloride are indicative of infiltration of fertilizers, highway runoff, or water from leaky sewers. Organic contaminants were widely detected in these wells at relatively low concentrations, indicating diffuse sources. Samples from wells screened in terrace deposits were characterized by highly variable chemical concentrations as a result of diverse hydrogeologic conditions and potential variability in urban sources of contamination. Some samples contained high concentrations of nitrate and sulfate, a variety of pesticide compounds, or hydrocarbon-related compounds, whereas others showed minimal anthropogenic impacts. Groundwater in alluvial deposits along the Anacostia River and its tributaries is generally anoxic with very high concentrations of dissolved iron and little detectable sulfate or nitrate. Concentrations of ammonia, organic nitrogen and arsenic were generally higher than those in groundwater from the Potomac Group or terrace deposits, and may be derived from natural sources. Detection frequencies and concentrations of organic contaminants were generally lower in groundwater from alluvial deposits than in groundwater from other groups, likely reflecting the fine-grained nature of sediments in recharge areas and diffuse sources of contaminants.

Groundwater-flow rates and traveltimes must be considered when interpreting groundwater quality and geochemistry. One or more decades are generally required for the movement of groundwater from the water table to local discharge areas in the Atlantic Coastal Plain, although traveltimes may be significantly altered by dewatering, leaking sewer lines, or other human influences. Groundwater in confined aquifers is generally much older than groundwater in unconfined aquifers. Groundwater quality reflects human sources of compounds in the recharge areas during the time of recharge, which may change drastically over time. Several compounds that have not been used in many years remain detectable in groundwater of the tidal Anacostia River watershed, including dieldrin, heptachlor epoxide, p,p'-DDE, and chlordane. Many years may be required for the effects of watershed management practices, such as low-impact development, to be reflected throughout the aquifer system.

The transport of chemical compounds from human sources from the land surface, through groundwater, to the Anacostia River and other local streams is likely in the tidal Anacostia River watershed. Many anthropogenic compounds are soluble in water and have been detected in shallow groundwater of the study area. Groundwater flow is typically very slow under natural conditions, but may be accelerated by human alterations of local hydrology. The Anacostia River is the ultimate destination for most shallow groundwater in the study area, although the transport of dissolved constituents may be impeded by changing geochemical conditions. Groundwater seepage has been observed through bed sediments in the tidal Anacostia River. Interaction between the Anacostia River and the confined Patuxent aquifer is likely where intervening finer sediments of the Potomac Group claydominated lithofacies have been removed by erosion or other processes, and infiltration of river water into the aquifer may occur if hydraulic heads in the confined aquifer drop below the level of water in the river. 


\section{References Cited}

A.C. Schultes of Maryland, Inc., [n.d.], National Arboretum wells \#1 \&\#2, job \#2616, [variously paged].

Anderson, A.L., Miller, C.V., Olsen, L.D., Doheny, E.J., and Phelan, D.J., 2002, Water quality, sediment quality, and stream-channel classification of

Rock Creek Park, Washington, D.C., 1999-2000: U.S. Geological Survey Water Resources Investigations Report 02-4067, 91 p., accessed September 30, 2019, at http://pubs.usgs.gov/wri/wri024067/.

Andreasen, D.C., 2007, Optimization of ground-water withdrawals in Anne Arundel County, Maryland, from the Upper Patapsco, Lower Patapsco, and Patuxent aquifers projected through 2044: Maryland Geological Survey Report of Investigations No. 77, 107 p., accessed September 30, 2019, at http://www.mgs.md.gov/ publications/report_pages/RI_77.html.

Ator, S.W., Denver, J.M., and Brayton, M.J., 2005, Hydrologic and geochemical controls on pesticide and nutrient transport to two streams on the Delmarva Peninsula: U.S. Geological Survey Scientific Investigations Report 2004-5051, 34 p., accessed September 30, 2019, at http://pubs.usgs.gov/sir/2004/5051/.

Bachman, L.J., and Phillips, P.J., 1996, Hydrologic landscapes on the Delmarva Peninsula Part 2: Estimates of base-flow nitrogen loads to Chesapeake Bay: Water Resources Bulletin, v. 32, no. 4, p. 779-791, accessed September 30, 2019, at https://onlinelibrary.wiley.com/doi/ abs/10.1111/j.1752-1688.1996.tb03475.x.

Behm, P., Buckley, A., and Schultz, C.L., 2003, TAM/WASP toxics screening level model for the tidal portion of the Anacostia River-Final report: Rockville, Maryland, Interstate Commission on the Potomac River Basin Report No. 03-2, 199 p., accessed September 30, 2019, at https://www.potomacriver.org/wp-content/uploads/2014/12/ ICPRB03-2.pdf.

Bouwer, H., and Rice, R.C., 1976, A slug test for determining hydraulic conductivity of unconfined aquifers with completely or partially penetrating wells: Water Resources Research, v. 12, no. 3, p. 423-428, accessed September 30, 2019, at https://agupubs.onlinelibrary.wiley.com/ doi/10.1029/WR012i003p00423.

Butler, J.J., 1998, The design, performance, and analysis of slug tests: Boca Raton, Florida, CRC Press LLC, 252 p.

Capel, P.D., Spexet, A.H., and Larson, S.J., 1999, Occurrence and behavior of the herbicide prometon in the hydrologic system: Environmental Science and Technology, v. 33, no. 5, p. 674-680, accessed September 30, 2019, at https://pubs.acs.org/doi/abs/10.1021/es9807340.
Chadwick, D.B., Katz, C.N., Groves, J.G., Carlson, A.R., Smith, C.F., Paulsen, R.J., O'Rourke, D., and Gahr, N., 2001, Anacostia River seepage and porewater survey report—DRAFT: San Diego, California, SPAWAR Systems Center, [variously paged].

Cooke, C.W., Martin, R.O.R., and Meyer, G., 1952, Geology and water resources of Prince George's County: State of Maryland Department of Geology, Mines, and Water Resources Bulletin 10, 270 p., accessed September 30, 2019, at http://www.mgs.md.gov/publications/report_pages/ BULL_10.html

Cooper, H.H., Jr., Bredehoeft, J.D., and Papadopulos, I.S., 1967, Response of a finite-diameter well to an instantaneous charge of water: Water Resources Research, v. 3, no. 1, p. 263-269, accessed September 30, 2019, at https://agupubs.onlinelibrary.wiley.com/doi/abs/10.1029/ WR003i001p00263.

D.C. Water Resources Research Center, 1992, Background study of groundwater in the District of ColumbiaAssessment of the groundwater in the District of Columbia: D.C. Water Resources Research Center Report No. 103, $122 \mathrm{p}$.

D.C. Water Resources Research Center, 1993a, Groundwater resource assessment study for the District of ColumbiaWell drilling and field operations report for the group A wells: DC WRRC Report No. 126, [variously paged].

D.C. Water Resources Research Center, 1993b, Groundwater resource assessment study for the District of ColumbiaWell drilling and field operations report for the group B wells: DC WRRC Report No. 127, [variously paged].

Denver, J.M., Ator, S.W., Debrewer, L.M., Ferrari, M.J., Barbaro, J.R., Hancock, T.C., Brayton, M.J., and Nardi, M.R., 2004, Water quality in the Delmarva Peninsula, Delaware, Maryland, and Virginia, 1999-2001: U.S. Geological Survey Circular 1228, 30 p., accessed September 30, 2019, at http://pubs.usgs.gov/circ/2004/1228/.

Denver, J.M., Ator, S.W., Fischer, J.M., Harned, D.C., Schubert, C., and Szabo, Z., 2014, The quality of our Nation's waters - Water quality in the Northern Atlantic Coastal Plain surficial aquifer system, Delaware, Maryland, New Jersey, New York, North Carolina, and Virginia, 1988-2009: U.S. Geological Survey Circular 1353, 88 p., accessed September 30, 2019, at https://doi.org/10.3133/cir1353.

District of Columbia, 1993, Groundwater standards, District of Columbia Municipal Regulations, Title 21, Section 1155.3, accessed September 11, 2008, at http://doh.dc.gov/doh/ frames.asp?doc $=/ \mathrm{doh} / \mathrm{lib} / \mathrm{doh} /$ services/administration offices/environmental/services2/water_division/pdf/ groundwaterquality.pdf\&group $=1811$. 
District Department of the Environment, 2010, Anacostia River Monitoring Program, accessed August 31, 2010, at http://ddoe.dc.gov/ddoe/cwp/view,a,1209,q,497570.asp.

Drummond, D.D., 2007, Water-supply potential of the Coastal Plain aquifers in Calvert, Charles, and St. Mary's Counties, Maryland, with emphasis on the Upper Patapsco and Lower Patapsco Aquifers: Maryland Geological Survey Report of Investigations No. 76, 236 p., accessed September 30, 2019, at http://www.mgs.md.gov/publications/report pages/ RI_76.html.

Dunkle, S.A., Plummer, L.N., Busenberg, E., Phillips, P.J., Denver, J.M., Hamilton, P.A., Michel, R.L., and Coplen, T.B., 1993, Chlorofluorocarbons $\left(\mathrm{CCl}_{3} \mathrm{~F}\right.$ and $\mathrm{CCl}_{2} \mathrm{~F}_{2}$ ) as dating tools and hydrologic tracers in shallow groundwater of the Delmarva Peninsula, Atlantic Coastal Plain, United States: Water Resources Research, v. 29, no. 12, p. 3837-3860, accessed September 30, 2019, at https://agupubs.onlinelibrary.wiley.com/doi/ abs/10.1029/93WR02073.

Eckhardt, D.A.V., and Stackelberg, P.E., 1995, Relation of groundwater quality to land use on Long Island, New York: Groundwater, v. 33, no. 6, p. 1019-1033, accessed September 30, 2019, at https://ngwa.onlinelibrary.wiley. com/doi/abs/10.1111/j.1745-6584.1995.tb00047.x.

Fenneman, N.M., and Johnson, D.W., 1946, Physical divisions of the United States: U.S. Geological Survey Map, 1 sheet, scale $1: 7,000,000$.

Fleck, W.B., and Vroblesky, D.A., 1996, Simulation of ground-water flow of the Coastal Plain aquifers in parts of Maryland, Delaware, and the District of Columbia: U.S. Geological Survey Professional Paper 1404-J, 41 p.

Focazio, M.J., Plummer, L.N., Böhlke, J.K., Busenberg, E., Bachman, L.J., and Powars, D.S., 1998, Preliminary estimates of residence times and apparent ages of groundwater in the Chesapeake Bay watershed, and water-quality data from a survey of springs: U.S. Geological Survey Water-Resources Investigations Report 97-4225, 75 p., accessed September 30, 2019, at https://pubs.usgs.gov/wri/wri97-4225/wrir-97-4225.pdf.

Gilliom, R.J., Barbash, J.E., Crawford, C.G., Hamilton, P.A., Martin, J.D., Nakagaki, N., Nowell, L.H., Scott. J.C., Stakelberg, P.E., Thelin, G.P., and Wolock, D.M., 2006, The quality of our Nation's waters-Pesticides in the Nation's streams and groundwater, 1992-2001: U.S. Geological Survey Circular 1291, 172 p., accessed September 30, 2019, at http://pubs.usgs.gov/circ/2005/1291/.
Greeley and Hansen, 2009, District of Columbia Water and Sewer Authority, Sewer system facilities plan executive summary: 30 p, accessed March 10, 2014, at http://www.dcwater.com/news/publications/Sewer $\% 20$ System $\% 20$ Facilities $\% 20$ Plan-Executive $\% 20$ Summary $\% 20$ June\%202009.pdf.

Greene, E.A., and Shapiro, A.M., 1995, Methods of conducting air-pressurized slug tests and computation of type curves for estimating transmissivity and storativity: U.S. Geological Survey Open-File Report 95-424, 43 p., accessed September 30, 2019, at https://pubs.er.usgs.gov/publication/ofr95424.

Hamilton, P.A., Denver, J.M., Phillips, P.J., and Shedlock, R.J., 1993, Water-quality assessment of the Delmarva Peninsula, Delaware, Maryland, and Virginia-Effects of agricultural activities on, and distribution of, nitrate and other inorganic constituents in the surficial aquifer: U.S. Geological Survey Open-File Report 93-40, 87 p., accessed September 30, 2019, at https://pubs.er.usgs.gov/publication/ofr9340.

Hansen, H.J., 1968, Geophysical log cross-section of network of the Cretaceous sediments of Southern Maryland: Maryland Geological Survey Report of Investigations No. 7, 46 p., 17 pls., accessed September 30, 2019, at http://www.mgs.md.gov/publications/report_pages/RI_7. html.

Hem, J.D., 1992, Study and interpretation of the chemical characteristics of natural water (3d ed.): U.S. Geological Survey Water-Supply Paper 2254, 263 p.

Hickman, R.E., 2004, Pesticide compounds in streamwater in the Delaware River Basin, December 1998-August 2001: U.S. Geological Survey Scientific Investigations Report 2004-5105, 36 p., accessed September 30, 2019, at http://pubs.usgs.gov/sir/2004/5105/.

HSI Geotrans Inc., 1998, Deep production well reportAquatic resource education center, Anacostia Park, Washington, D.C.: Glenn Allen, Virginia, HSI Geotrans, [variously paged].

Johnston, P.M., 1964, Geology and ground-water resources of Washington, D.C. and vicinity: U.S. Geological Survey Water-Supply Paper 1776, 98 p., accessed September 30, 2019, at https://pubs.usgs.gov/wsp/1776/report.pdf.

Kiely, T., Donaldson, D., and Grube, A., 2004, Pesticide industry sales and usage: 2000 and 2001 market estimates: Washington, D.C., U.S. Environmental Protection Agency, accessed March 29, 2006, at http://www.epa.gov/oppbead1/ pestsales/01pestsales/market_estimates2001.pdf. 
Klohe, C.A., and Debrewer, L.M., 2007, Summary of ground-water-quality data in the Anacostia River watershed, Washington, D.C., SeptemberDecember 2005: U.S. Geological Survey Open-File Report 2006-1392, 74 p., accessed September 30, 2019, at http://pubs.usgs.gov/of/2006/1392/.

Kolpin, D.W., Furlong, E.T., Meyer, M.T., Thurman, E.M., Zaugg, S.D., Barber, L.B., and Buxton, H.T., 2002, Pharmaceuticals, hormones, and other organic wastewater contaminants in U.S. streams, 19992000-A national reconnaissance: Environmental Science \& Technology, v. 26, no. 6, p. 1202-1211, DOI: $10.1021 /$ es011055j, accessed September 30, 2019, at https://pubs.acs.org/doi/10.1021/es011055j.

Koterba, M.T., Dieter, C.A., and Miller, C.V., 2010, Pesticides in groundwater in the Anacostia River and Rock Creek watersheds in Washington, D.C., 2005 and 2008: U.S. Geological Survey Scientific Investigations Report 2010-5130, 90 p., accessed February 18, 2020, at https://doi.org/10.3133/sir20105130.

MACTEC Engineering and Consulting, Inc., 2005, Preliminary geotechnical services-South Capitol Street Bridge, Washington, D.C.: Sterling, Virginia, [variously paged.]

Matheson, G.M., Schneider, J,, Zmijewski, D., and Amini, F., 1994, Definition of groundwater flow in the water table aquifer of the southern Anacostia River Basin: D.C. Water Resources Research Center Report No. 147, 42 p.

Mathews, E.B., 1933, Map of Maryland showing geological formations: Maryland Geological Survey Map, 1 sheet, scale 1: 380,160 .

Matrix Environmental and Geotechnical Services, 2003, Quantifying specific discharge across the sedimentwater interface within a test area of the Anacostia River, Washington, D.C.-A pre-capping evaluation-Data report: Florham Park, New Jersey, [variously paged].

Miller, C.V., Denis, J.M., Ator, S.W., and Brakebill, J.W., 1997, Nutrients in streams during baseflow in selected environmental settings of the Potomac River Basin: Journal of the American Water Resources Association, v. 33, no. 6, p. 1155-1171, accessed September 30, 2019, at https://onlinelibrary.wiley.com/doi/ abs/10.1111/j.1752-1688.1997.tb03543.x.

Miller, C.V., and Klohe, C.A., 2003, Summary of waterand sediment-quality data for Anacostia River well sites sampled in July-August 2002: U.S. Geological Survey Open-File Report 2003-73, 48 p., accessed September 30, 2019, at http://pubs.usgs.gov/of/2003/ofr03-073/.
Moran, M.J., Lapham, W.W., Rowe, B.L., and Zogorski, J.S., 2002, Occurrence and status of volatile organic compounds in groundwater from rural, untreated, selfsupplied domestic wells in the United States, 1986-99: U.S. Geological Survey Water-Resources Investigations Report 02-4085, 51 p., accessed September 30, 2019, at https://pubs.usgs.gov/wri/2002/4085/report.pdf.

National Oceanographic and Atmospheric Administration, 2013, Precipitation data, accessed October 30, 2013 at http://www.erh.noaa.gov/lwx/climate/dca/dcaprecip.txt.

Otton, E.G., 1955, Ground-water resources of the Southern Maryland Coastal Plain: Maryland Department of Geology, Mines, and Water Resources Bulletin 15, 347 p.

Papadopulos, S.S., Bennett, R.R., Mack, F.K., and Trescott, P.C., 1974, Water from the Coastal Plain aquifers in the Washington, D.C. metropolitan area: U.S. Geological Survey Circular 697, 11 p., accessed September 30, 2019, at https://pubs.usgs.gov/circ/1974/0697/report.pdf.

Reed, J.C., Jr., and Obermeier, S.F., 1982, The geology beneath Washington, D.C.-The foundations of a Nation's capital: Geological Society of America Reviews in Engineering Geology v. 5, 24 p.

Reiser, R.G., 1999, Relation of pesticide concentrations to season, streamflow, and land use in seven New Jersey streams: U.S. Geological Survey Water-Resources Investigations Report 99-4154, 19 p., accessed September 30, 2019, at https://pubs.er.usgs.gov/publication/wri994154.

Ridolfi Inc., 2005, Site characterization report, Poplar Point, Washington, D.C., 76 p., accessed September 11, 2008, at http://response.restoration.noaa.gov/book_shelf/126 Poplar_Point_Site_Char_Report.pdf.

Schnabel Engineering Associates, 1995, Final submittalWater system upgrade, U.S. National Arboretum, Washington, D.C.-Phase II-Hydrologic study irrigation water supply well PW-3 development, BJI JO 90328-01, Bethesda, Maryland, [variously paged].

Somes, G.C., 2003, Deep aquifer exploration and testing report, Arena Stage, Washington, D.C.: Quality Environmental Solutions, Inc., [variously paged].

Southworth, S., and Denenny, D., 2006, Geologic map of the National Parks in the National Capital Region, Washington, D.C., Virginia, Maryland, and West Virginia: U.S. Geological Survey Open-File Report 2005-1331, accessed October 1, 2019, at http://pubs.usgs.gov/of/2005/1331/. 
Squillace, P.J., Scott, J.C., Moran, M.J., Nolan, B.T., and Kolpin, D.W., 2002, VOCs, pesticides, nitrate, and their mixtures in groundwater used for drinking water in the United States: Environmental Science \& Technology, v. 36, no. 9, p. 1923-1930, accessed October 1, 2019, at https://pubs.acs.org/doi/abs/10.1021/es015591n.

Tenbus, F.J., 2003, Lithologic coring in the lower Anacostia tidal watershed, Washington, D.C., July 2002: U.S. Geological Survey Open-File Report 03-318, 62 p., accessed October 1, 2019, at https://pubs.usgs.gov/of/2003/ofr03-318/.

Thomas, M.A., 2000, The effect of residential development on groundwater quality near Detroit, Michigan: Journal of the American Water Resources Association, v. 36, no. 5, p. 1023-1038, accessed October 1, 2019, at https://doi.org/10.1111/j.1752-1688.2000.tb05707.x.

U.S. Geological Survey, 2009, Groundwater levels for the Nation (sites 54V 3 and PG Bc 16), accessed April 3, 2009, at http://waterdata.usgs.gov/nwis.

U.S. Geological Survey, 2017, USGS 01651750 Anacostia River Aquatic Gardens at Washington, DC, in USGS water data for the Nation: U.S. Geological Survey National Water Information System database, accessed November 8, 2019, at https://doi.org/10.5066/F7P55KJN. [Site information directly accessible at https://waterdata.usgs.gov/nwis/ inventory/?site_no $=01651750 \&$ agency_cd=USGS.]

Velinsky, D.J., Wade, T.L., Schlekat, C.E., McGee, B.L., and Presley, B.J., 1994, Tidal river sediments in the Washington, D.C. area: I. Distribution and sources of trace metals: Estuaries, v. 17, no. 2, p. 305-320.
Vroblesky, D.A., and Fleck, W.B., 1991, Hydrogeologic framework of the Coastal Plain of Maryland, Delaware, and the District of Columbia: U.S. Geological Survey Professional Paper 1404-E, 45 p., accessed October 1, 2019, at https://pubs.usgs.gov/pp/1404e/report.pdf.

Wade, T.L., Velinsky, D.J., Reinharz, E., and Schlekat, C.E., 1994, Tidal river sediments in the Washington, D.C. area: II. Distribution and sources of organic contaminants: Estuaries, v. 17, no. 2, p. 321-333, accessed October 1, 2019, at https://www.jstor.org/stable/1352666.

Williams, D.D., Williams, N.E., and Cao, Y., 1999, Road salt contamination of groundwater in a major metropolitan area and development of a biological index to monitor its impact: Water Research, v. 34, no. 1, p. 127-138, accessed October 1, 2019, at https://doi.org/10.1016/S0043-1354(99)00129-3.

Williams, G.P., 1977, Washington, D.C.'s vanishing springs and waterways: U.S. Geological Survey Circular 752, 19 p., accessed October 1, 2019, at https://pubs.er.usgs.gov/publication/cir752.

Washington Metropolitan Area Transit Authority (WMATA), 1981, Anacostia river crossing branch route subsurface investigation: Washington, D.C., Washington Metropolitan Area Transit Authority, [variously paged].

Zogorski, J.S., Carter, J.M., Ivahnenko, T., Lapham, W.W., Moran, M.J., Rowe, B.L., Squillace, P.J., and Toccalino, P.L., 2006, The quality of our Nation's watersVolatile organic compounds in the Nation's ground water and drinking-water supply wells: U.S. Geological Survey Circular 1292, 101 p., accessed October 1, 2019, at http://pubs.usgs.gov/circ/circ1292/. 


\section{Appendix 1. Selected Lithologic Core Descriptions in and near the Anacostia River Watershed}

\section{EXPLANATION}

\begin{tabular}{|c|l|}
\hline $\begin{array}{c}\text { Geologic } \\
\text { map units }\end{array}$ & \\
\hline $\mathrm{dgf}$ & Disturbed ground and artificial fill \\
\hline $\mathrm{Qa}$ & Alluvium (Holocene) \\
\hline $\mathrm{Qt}$ & Terrace deposits, low level (Holocene and Pleistocene) \\
\hline $\mathrm{Qte}$ & Low-level fluvial and estuarine deposits (Pleistocene) \\
\hline $\mathrm{Qfe}$ & Upper-level fluvial and estuarine deposits (Pleistocene) \\
\hline $\mathrm{Qtt}$ & Terrace deposits, upper level (Pleistocene and Tertiary) \\
\hline $\mathrm{Tt}$ & Terrace deposits (Tertiary) \\
\hline $\mathrm{Ttu}$ & Highest level upland terrace deposits (Tertiary) \\
\hline $\mathrm{Tc}$ & Calvert Formation (middle Miocene) \\
\hline $\mathrm{Ta}$ & Aquia Formation (upper Paleocene) \\
\hline $\mathrm{TKb}$ & Brightseat Formation and Monmouth Group, undivided (lower Paleocene and upper Cretaceous) \\
\hline $\mathrm{Km}$ & Monmouth Formation \\
\hline $\mathrm{Kpc}$ & Potomac Group clay-dominated lithofacies \\
\hline $\mathrm{Kps}$ & Potomac Group sand-dominated lithofacies \\
\hline bedrock & All consolidated Paleozoic and older rock \\
\hline
\end{tabular}

[Please note that this appendix presents lithologic descriptions from many different references, as noted in the header information, and descriptions by USGS personnel not previously published. Descriptions from cited references were not modified, except as noted; therefore descriptions presented in this appendix are not necessarily consistent with regards to terminology, punctuation, etc. Designations of tops and bottoms of geologic map units shown in this appendix were determined by the authors, with the exception of DC2, PG Cc 13, PG Cd 9, PG Dc 1, PG Dc 3, PG Dc 4, PG Eb 1, WE Ca 6, and WW Cc 26.] 
Appendix 1. Lithologic descriptions.

Site name: AC Aa 2 (described by C. Klohe on March 6, 2006)

Altitude: 125.59 feet Total depth: 24 feet

Latitude / Longitude: $38^{\circ} 51^{\prime} 57.4^{\prime \prime} \mathrm{N} / 76^{\circ} 58^{\prime} 03.3^{\prime \prime} \mathrm{W}$

\begin{tabular}{|c|c|c|c|c|}
\hline $\begin{array}{l}\text { Geologic } \\
\text { map } \\
\text { units }\end{array}$ & Description & $\begin{array}{l}\text { Depth to top } \\
\text { of interval } \\
\text { (feet) }\end{array}$ & $\begin{array}{l}\text { Depth to bottom } \\
\text { of interval } \\
\text { (feet) }\end{array}$ & $\begin{array}{l}\text { Thickness } \\
\text { (feet) }\end{array}$ \\
\hline $\operatorname{dgf}$ & $\begin{array}{l}\text { Soil, and fill (dark gray gravel, light brown to yellow-orange sandy silt. ( } 2.3 \text { feet } \\
\text { of recovery) }\end{array}$ & 0.0 & 4.0 & 4.0 \\
\hline \multirow{2}{*}{$\mathrm{TKb}$} & $\begin{array}{l}\text { Light brown to yellow-orange silty sand. Brown, silty, fine-grained sand with } \\
\text { gravels, woody organic material, and light gray clay. ( } 2 \text { feet of core recovery) }\end{array}$ & 4.0 & 8.0 & 4.0 \\
\hline & $\begin{array}{l}\text { Black, organic rich (wood pieces), silty sand. Light gray clayey sand. Light gray } \\
\text { clay. Light gray clay with very thin layers of black organic material (leaves?). } \\
\text { Layer of } 0.4 \text {-inch diameter pebbles. Layer of light gray to medium gray clay. } \\
\text { (2 feet of recovery) }\end{array}$ & 12.0 & 16.0 & 4.0 \\
\hline \multirow[t]{3}{*}{ Kpc } & $\begin{array}{l}\text { Light gray silty clay mottled with yellow-orange silty clay. medium- to coarse- } \\
\text { grained dark minerals. }\end{array}$ & 21.0 & 22.0 & 1.0 \\
\hline & Light gray to yellow-orange silt with some thin layers of very fine-grained sand. & 22.0 & 23.0 & 1.0 \\
\hline & Light gray clay mottled with maroon-red clay. & 23.0 & 24.0 & 1.0 \\
\hline
\end{tabular}

Appendix 1. Lithologic descriptions.-Continued

Site name: $A C$ Ab 3 (described by C. Klohe on March 13, 2006)

Altitude: 205 feet Total depth: 36 feet

Latitude / Longitude: $38^{\circ} 52^{\prime} 07.1^{\prime \prime} \mathrm{N} / 76^{\circ} 57^{\prime} 07.6^{\prime \prime} \mathrm{W}$

\begin{tabular}{|c|c|c|c|c|}
\hline $\begin{array}{l}\text { Geologic } \\
\text { map } \\
\text { units }\end{array}$ & Description & $\begin{array}{l}\text { Depth to top } \\
\text { of interval } \\
\text { (feet) }\end{array}$ & $\begin{array}{c}\text { Depth to bottom } \\
\text { of interval } \\
\text { (feet) }\end{array}$ & $\begin{array}{l}\text { Thickness } \\
\text { (feet) }\end{array}$ \\
\hline \multirow[t]{2}{*}{$\operatorname{dgf}$} & $\begin{array}{l}\text { Light gray and yellow-orange clay with poorly sorted, angular gravels. Some } \\
\text { zones with poorly sorted coarse sand }\end{array}$ & 0 & 3.5 & 3.5 \\
\hline & Medium brown silt with organic matter & 3.5 & 4.0 & 0.5 \\
\hline \multirow{4}{*}{$\mathrm{TKb}$} & Medium brown-gray silty clay with organic matter and gravels & 4.0 & 5.5 & 1.5 \\
\hline & $\begin{array}{l}\text { Light brown, pooly sorted clayey coarse sand and gravel. Angular to well- } \\
\text { rounded quartzite gravels }(0.12 \text { - to } 1.25 \text {-inch diameter })\end{array}$ & 8.0 & 9.5 & 1.5 \\
\hline & Light gray, poorly sorted coarse sand and gravel (subrounded) & 9.5 & 11.5 & 2.0 \\
\hline & $\begin{array}{l}\text { Light brown-gray clayey silt with poorly sorted gravel (0.12- to } 0.75 \text {-inch diam- } \\
\text { eter) }\end{array}$ & 11.5 & 13.5 & 2.0 \\
\hline \multirow{2}{*}{ Kpc } & Light gray and reddish-brown mottled clay. Organic matter at 21.5 feet. & 20.0 & 32.0 & 12.0 \\
\hline & Gray clay & 32.0 & 36.0 & 4.0 \\
\hline
\end{tabular}


Appendix 1. Lithologic descriptions.-Continued

Site name: Arena Stage (from Somes, 2003)

Altitude: 14 feet Total depth: 183 feet

Latitude / Longitude: $38^{\circ} 52^{\prime} 37.01^{\prime \prime} \mathrm{N} / 77^{\circ} 01^{\prime} 12.97^{\prime \prime} \mathrm{W}$

\begin{tabular}{|c|c|c|c|c|}
\hline $\begin{array}{l}\text { Geologic } \\
\text { map } \\
\text { units }\end{array}$ & Description & $\begin{array}{c}\text { Depth to top } \\
\text { of interval } \\
\text { (feet) }\end{array}$ & $\begin{array}{c}\text { Depth to bottom } \\
\text { of interval } \\
\text { (feet) }\end{array}$ & $\begin{array}{c}\text { Thickness } \\
\text { (feet) }\end{array}$ \\
\hline \multirow{2}{*}{$\operatorname{dgf}$} & Top soil & 0.0 & 1.0 & 1.0 \\
\hline & Brown sandy clay with fill & 1.0 & 6.0 & 5.0 \\
\hline \multirow{2}{*}{ Qte } & Brown clay with some fine sand & 6.0 & 14.0 & 8.0 \\
\hline & Hard layer of stones and pea gravel (slow) & 14.0 & 32.0 & 18.0 \\
\hline \multirow{5}{*}{ Kpc } & Orange and white and gray clay & 32.0 & 59.0 & 27.0 \\
\hline & Medium to coarse sand & 59.0 & 74.0 & 15.0 \\
\hline & Gray and red clay (slow) & 74.0 & 115.0 & 41.0 \\
\hline & Fine to medium sand with some clay & 115.0 & 124.0 & 9.0 \\
\hline & Red and gray clay (slow) & 124.0 & 139.0 & 15.0 \\
\hline Kps & Fine to coarse sand with some clay & 139.0 & 182.0 & 43.0 \\
\hline bedrock & Hard layer & 182.0 & 183.0 & 1.0 \\
\hline
\end{tabular}

Appendix 1. Lithologic descriptions.-Continued

Site name: AX Ac 2 (BPS-42), (Anthony Harding, DC Clean Rivers Project, written commun., 2011)

Altitude: 10.16 feet Total depth: 326 feet

Latitude / Longitude: $38^{\circ} 52^{\prime} 28.39^{\prime \prime} \mathrm{N} / 77^{\circ} 00^{\prime} 11.91^{\prime \prime} \mathrm{W}$

Core used in section $\mathrm{C}^{-C^{\prime}}$

\begin{tabular}{|c|c|c|c|c|}
\hline $\begin{array}{l}\text { Geologic } \\
\text { map } \\
\text { units }\end{array}$ & Description & $\begin{array}{l}\text { Depth to top } \\
\text { of interval } \\
\text { (feet) }\end{array}$ & $\begin{array}{l}\text { Depth to bottom } \\
\text { of interval } \\
\text { (feet) }\end{array}$ & $\begin{array}{l}\text { Thickness } \\
\text { (feet) }\end{array}$ \\
\hline \multirow{2}{*}{$\operatorname{dgf}$} & $\begin{array}{l}\text { (Fill) Sampled as moist, brown to dark brown, fine to coarse, Silty Sand With } \\
\text { Gravel, estimated } 15-25 \% \text { fines, estimated } 15-25 \% \text { gravel, subangular to } \\
\text { subrounded gravel, contains brick fragments, upper } 0.5 \text { feet contains asphalt } \\
\text { and concrete }\end{array}$ & 0 & 8 & 8 \\
\hline & $\begin{array}{l}\text { (FILL) Sampled as wet, dark grayish brown, medium plasticity, Lean Clay, es- } \\
\text { timated 5-10\% fine to coarse gravel and cobbles (1-inch to } 3 \text {-inch diameter), } \\
\text { angular to subangular, contains wood debris }\end{array}$ & 11 & 21 & 10 \\
\hline \multirow[t]{3}{*}{ Qte } & $\begin{array}{l}\text { Moist, very dark grayish brown and very dark brown, ORGANIC SILT WITH } \\
\text { SAND, estimated } 15-25 \% \text { fine to medium sand, moderate organic odor, } \\
\text { numerous organics, contains wood fibers, approximately } 1 \text {-inch to } 3 \text {-inch peat } \\
\text { layers from } 21 \text { feet to } 25 \text { feet. Pleistocene marsh deposits from pollen analy- } \\
\text { sis, Christopher Bernhardt, written commun. At } 25.0 \text { feet changes to estimated } \\
30-40 \% \text { fines }\end{array}$ & 21 & 30 & 9 \\
\hline & $\begin{array}{l}\text { Wet, dark grayish brown, fine to coarse, WELL GRADED GRAVEL, subround- } \\
\text { ed gravel }\end{array}$ & 30 & 39.5 & 9.5 \\
\hline & $\begin{array}{l}\text { Moist, dark grayish brown, low plasticity, LEAN CLAY WITH SAND, } \\
\text { estimated } 15-25 \% \text { fine sand, } 4 \text {-inch cobble encountered at } 42 \text { feet }\end{array}$ & 39.5 & 42 & 2.5 \\
\hline
\end{tabular}


Appendix 1. Lithologic descriptions.-Continued

Site name: AX Ac 2 (BPS-42), (Anthony Harding, DC Clean Rivers Project, written commun., 2011)

Altitude: 10.16 feet Total depth: 326 feet

Latitude / Longitude: $38^{\circ} 52^{\prime} 28.39^{\prime \prime} \mathrm{N} / 77^{\circ} 00^{\prime} 11.91^{\prime \prime} \mathrm{W}$

Core used in section C-C'

\begin{tabular}{|c|c|c|c|c|}
\hline $\begin{array}{l}\text { Geologic } \\
\text { map } \\
\text { units }\end{array}$ & Description & $\begin{array}{l}\text { Depth to top } \\
\text { of interval } \\
\text { (feet) }\end{array}$ & $\begin{array}{l}\text { Depth to bottom } \\
\text { of interval } \\
\text { (feet) }\end{array}$ & $\begin{array}{l}\text { Thickness } \\
\text { (feet) }\end{array}$ \\
\hline \multirow{7}{*}{ Qte } & $\begin{array}{l}\text { Wet, dark gray, fine to medium, POORLY GRADED SAND, estimated }<5 \% \\
\text { fine sand. At } 43.7 \text { feet contains 3-inch layer of silt with wood fibers }\end{array}$ & 42 & 44.5 & 2.5 \\
\hline & $\begin{array}{l}\text { Wet, dark gray, fine to medium, POORLY GRADED SAND WITH GRAVEL, } \\
\text { estimated } 30-45 \% \text { gravel, estimated }<5 \% \text { fines, subrounded gravel, contains } \\
\text { 6-inch layer of moist to wet, light gray to dark gray, fine to medium POORLY } \\
\text { GRADED SAND WITH SILT, estimated } 5-10 \% \text { fines }\end{array}$ & 44.5 & 52 & 7.5 \\
\hline & $\begin{array}{l}\text { Moist, very stiff, reddish brown and olive brown, high plasticity, FAT CLAY, } \\
\text { estimated }<5 \% \text { fine sand }\end{array}$ & 52 & 54 & 2 \\
\hline & $\begin{array}{l}\text { Moist, dark yellowish brown and light gray, low plasticity, fine to medium, } \\
\text { SILTY SAND, estimated } 15-25 \% \text { fines }\end{array}$ & 54 & 57 & 3 \\
\hline & $\begin{array}{l}\text { Moist, dark yellowish brown and light gray, fine to medium, POORLY GRAD- } \\
\text { ED SAND WITH SILT, estimated 5-10\% fines }\end{array}$ & 57 & 61 & 4 \\
\hline & $\begin{array}{l}\text { Moist to wet, gray, fine to medium, POORLY GRADED SAND WITH CLAY, } \\
\text { estimated } 5-10 \% \text { fines }\end{array}$ & 62 & 67.5 & 5.5 \\
\hline & $\begin{array}{l}\text { Moist, very stiff, gray and olive brown, medium plasticity, SANDY FAT CLAY, } \\
\text { estimated } 30-45 \% \text { fine sand. At } 73.0 \text { feet changes to estimated } 30-45 \% \\
\text { lignite, contains approximately } 4 \text {-inch layer of crisp lignite }\end{array}$ & 67.5 & 75 & 7.5 \\
\hline \multirow{9}{*}{ Kps } & Moist to wet, gray, fine to medium, CLAYEY SAND, estimated $15-25 \%$ fines & 75 & 76 & 1 \\
\hline & Wet, gray, fine to medium, POORLY GRADED SAND, estimated $<5 \%$ fines & 76 & 77.5 & 1.5 \\
\hline & Moist to wet, gray, fine to medium, CLAYEY SAND, estimated $15-25 \%$ fines & 77.5 & 80 & 2.5 \\
\hline & $\begin{array}{l}\text { Wet, light gray, fine to medium, CLAYEY SAND, estimated } 15-25 \% \text { fines, esti- } \\
\text { mated }<5 \% \text { fine gravel. At } 92.5 \text { feet contains } 6 \text {-inch layer of SANDY CLAY }\end{array}$ & 80 & 95 & 15 \\
\hline & $\begin{array}{l}\text { Moist, very stiff, dark gray, high plasticity, FAT CLAY, estimated }<5 \% \text { fine } \\
\text { sand. At } 106.0 \text { feet fine sand lamination present from } 106 \text { feet to } 109.5 \text { feet }\end{array}$ & 105 & 109.5 & 4.5 \\
\hline & $\begin{array}{l}\text { Moist, dark gray and light gray, high plasticity, SANDY FAT CLAY, estimated } \\
30-45 \% \text { fine to medium sand (present in layers/laminations, interbedded with } \\
\text { clay), contains 6-inch layers of POORLY GRADED SAND WITH CLAY and } \\
\text { POORLY GRADED SAND at } 113 \text { feet and } 113.5 \text { feet }\end{array}$ & 109.5 & 114 & 4.5 \\
\hline & $\begin{array}{l}\text { Moist, gray to very dark gray, fine to medium, POORLY GRADED SAND } \\
\text { WITH SILT, estimated 5-10\% fines, estimated 30-45\% lignite, crisp lignite }\end{array}$ & 114 & 116.5 & 2.5 \\
\hline & $\begin{array}{l}\text { Moist, dark gray, fine, SILTY SAND, estimated 30-45\% fines, low plasticity, } \\
\text { laminated }\end{array}$ & 116.5 & 115.5 & 1 \\
\hline & Moist, dark gray, medium plasticity, LEAN CLAY WITH SAND, estimated & 117.5 & 125.5 & 8 \\
\hline
\end{tabular}
$15-25 \%$ fine sand. Patuxent Formation from pollen analysis, Raymond Christopher, written commun. 
Appendix 1. Lithologic descriptions.-Continued

Site name: AX Ac 2 (BPS-42), (Anthony Harding, DC Clean Rivers Project, written commun., 2011)

Altitude: 10.16 feet Total depth: 326 feet

Latitude / Longitude: $38^{\circ} 52^{\prime} 28.39^{\prime \prime} \mathrm{N} / 77^{\circ} 00^{\prime} 11.91^{\prime \prime} \mathrm{W}$

Core used in section $\mathrm{C}-\mathrm{C}^{\prime}$

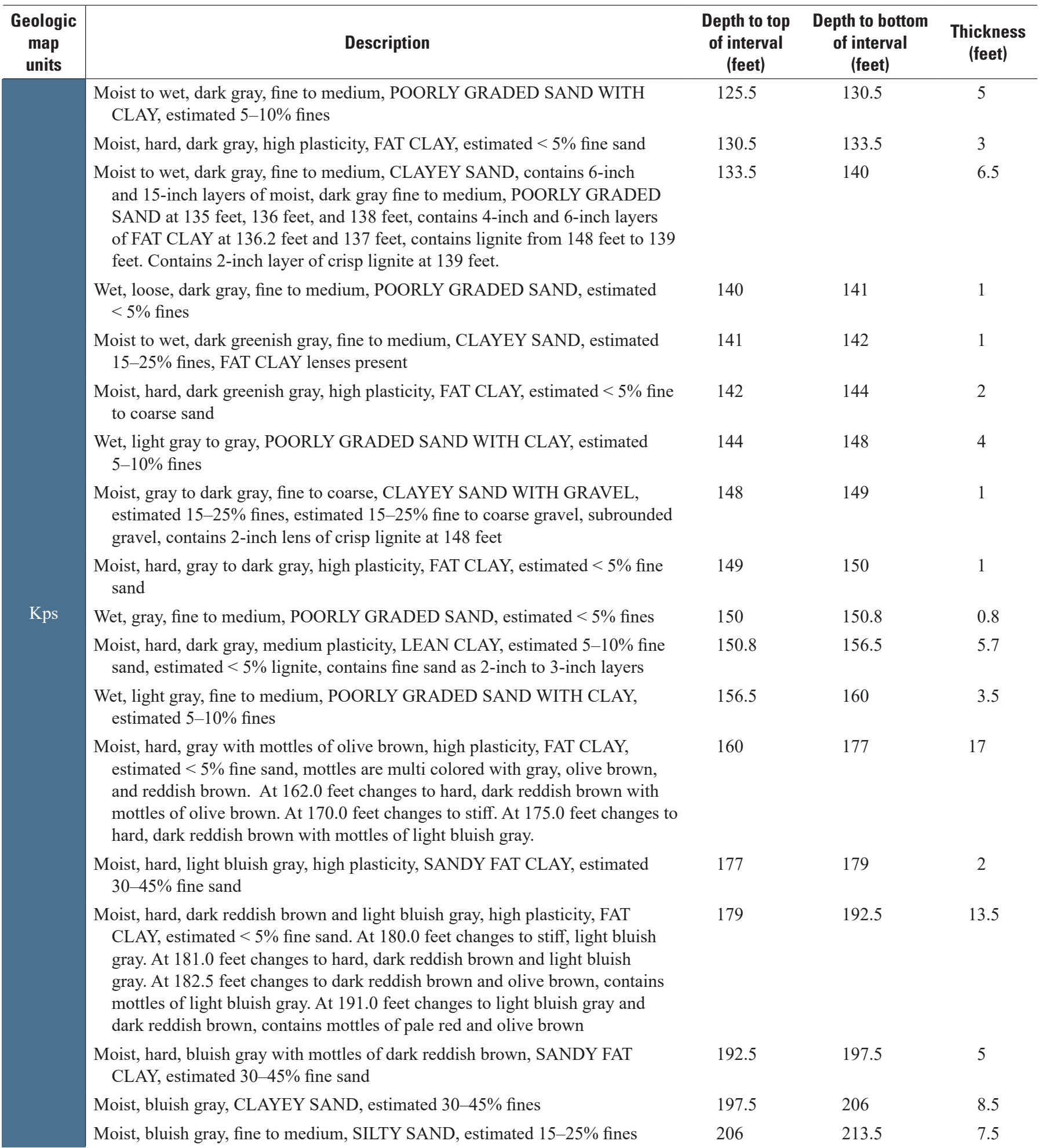


Appendix 1. Lithologic descriptions.-Continued

Site name: AX Ac 2 (BPS-42), (Anthony Harding, DC Clean Rivers Project, written commun., 2011)

Altitude: 10.16 feet Total depth: 326 feet

Latitude / Longitude: $38^{\circ} 52^{\prime} 28.39^{\prime \prime} \mathrm{N} / 77^{\circ} 00^{\prime} 11.91^{\prime \prime} \mathrm{W}$

Core used in section C-C'

\begin{tabular}{|c|c|c|c|c|}
\hline $\begin{array}{l}\text { Geologic } \\
\text { map } \\
\text { units }\end{array}$ & Description & $\begin{array}{l}\text { Depth to top } \\
\text { of interval } \\
\text { (feet) }\end{array}$ & $\begin{array}{l}\text { Depth to bottom } \\
\text { of interval } \\
\text { (feet) }\end{array}$ & $\begin{array}{l}\text { Thickness } \\
\text { (feet) }\end{array}$ \\
\hline & $\begin{array}{l}\text { Moist, hard, bluish gray with mottles of reddish brown, medium plasticity, FAT } \\
\text { CLAY, estimated } 5-10 \% \text { fine sand. At } 220.0 \text { feet changes to light bluish gray } \\
\text { and dark reddish brown, estimated }<5 \% \text { fine sand. At } 222.0 \text { feet contains thin } \\
\text { ( }<0.1 \text { feet) fine to medium gravel lenses at } 222 \text { feet and } 226 \text { feet }\end{array}$ & 213.5 & 227 & 13.5 \\
\hline & $\begin{array}{l}\text { Moist, light bluish gray, medium plasticity, SANDY LEAN CLAY, estimated } \\
30-45 \% \text { fine sand }\end{array}$ & 227 & 230 & 3 \\
\hline & $\begin{array}{l}\text { Moist to wet, light bluish gray, fine to medium, CLAYEY SAND, estimated } \\
15-25 \% \text { fines }\end{array}$ & 230 & 237 & 7 \\
\hline & $\begin{array}{l}\text { Moist, hard, dark greenish gray, low plasticity, LEAN CLAY, estimated } 5-10 \% \\
\text { fine sand. At } 244.5 \text { feet changes to dark greenish gray with mottles of olive } \\
\text { brown }\end{array}$ & 237 & 249 & 12 \\
\hline & $\begin{array}{l}\text { Wet to moist, medium stiff to stiff, dark grayish brown, medium plasticity, } \\
\text { SANDY SILT, estimated 5-10\% fine sand }\end{array}$ & 249 & 251 & 2 \\
\hline & Moist, hard, dark gray, medium plasticity, LEAN CLAY & 251 & 258 & 7 \\
\hline & $\begin{array}{l}\text { Moist, dense, light bluish gray, fine to medium, CLAYEY SAND, estimated } \\
30-45 \% \text { fines }\end{array}$ & 258 & 260 & 2 \\
\hline & $\begin{array}{l}\text { Wet, dark gray, fine to coarse, WELL GRADED SAND WITH CLAY, estimated } \\
5-10 \% \text { fine gravel, estimated } 5-10 \% \text { fines, subrounded gravel }\end{array}$ & 260 & 262 & 2 \\
\hline & $\begin{array}{l}\text { Moist, bluish gray, fine to medium, SILTY SAND, estimated } 15-25 \% \text { fines, } \\
\text { contains } 2 \text {-inch crisp, dense lignite at } 265 \text { feet }\end{array}$ & 262 & 265.5 & 3.5 \\
\hline \multirow[t]{9}{*}{ Kps } & $\begin{array}{l}\text { Moist, hard, bluish gray, medium plasticity, LEAN CLAY, estimated } 5-10 \% \text { fine } \\
\text { sand. At } 276.0 \text { feet contains } 6 \text {-inch layer of moist dark gray, fine to medium, } \\
\text { CLAYEY SAND at } 276 \text { feet to } 276.5 \text { feet }\end{array}$ & 265.5 & 277 & 11.5 \\
\hline & $\begin{array}{l}\text { Moist to wet, bluish gray, fine to coarse, WELL GRADED SAND WITH CLAY, } \\
\text { estimated 5-10\% fines, estimated 5-10\% fine to coarse gravel, rounded to } \\
\text { subrounded gravel }\end{array}$ & 277 & 279 & 2 \\
\hline & $\begin{array}{l}\text { Moist to wet, bluish gray, fine to coarse, POORLY GRADED SAND WITH } \\
\text { SILT AND GRAVEL, estimated 5-10\% fines, estimated 15-25\% fine gravel, } \\
\text { subrounded gravel, weak cementation }\end{array}$ & 279 & 280.8 & 1.8 \\
\hline & $\begin{array}{l}\text { Moist, hard, bluish gray, high plasticity, FAT CLAY, estimated }<5 \% \text { fine sand, } \\
\text { very thinly bedded to very thinly laminated }\end{array}$ & 280.8 & 284 & 3.2 \\
\hline & $\begin{array}{l}\text { Moist, loose, bluish gray, fine to coarse, SILTY SAND, estimated } 15-25 \% \text { fines, } \\
\text { contains 2-inch layer of FAT CLAY at } 284.8 \text { feet }\end{array}$ & 284 & 286 & 2 \\
\hline & $\begin{array}{l}\text { Moist, loose, bluish gray, fine to coarse, SILTY GRAVEL WITH SAND, } \\
\text { estimated } 15-25 \% \text { fines, estimated } 15-25 \% \text { fine to coarse sand, rounded to } \\
\text { subrounded gravel, strong cementation }\end{array}$ & 286 & 286.7 & 0.7 \\
\hline & $\begin{array}{l}\text { Moist, hard, bluish gray, high plasticity, FAT CLAY, estimated }<5 \% \text { sand, very } \\
\text { thinly bedded to very thinly laminated }\end{array}$ & 286.7 & 289.5 & 2.8 \\
\hline & $\begin{array}{l}\text { Moist to wet, loose, bluish gray, fine to coarse, WELL GRADED SAND, esti- } \\
\text { mated }<5 \% \text { gravel, estimated }<5 \% \text { fines }\end{array}$ & 289.5 & 295 & 5.5 \\
\hline & Moist, loose, bluish gray, fine to coarse, WELL GRADED SAND WITH & 295 & 296 & 1 \\
\hline
\end{tabular}

GRAVEL, estimated 30-45\% gravel, rounded to subrounded gravel 
Appendix 1. Lithologic descriptions.-Continued

Site name: AX Ac 2 (BPS-42), (Anthony Harding, DC Clean Rivers Project, written commun., 2011)

Altitude: 10.16 feet Total depth: 326 feet

Latitude / Longitude: $38^{\circ} 52^{\prime} 28.39^{\prime \prime} \mathrm{N} / 77^{\circ} 00^{\prime} 11.91^{\prime \prime} \mathrm{W}$

Core used in section $\mathrm{C}^{-\mathrm{C}^{\prime}}$

\begin{tabular}{|c|c|c|c|c|}
\hline $\begin{array}{l}\text { Geologic } \\
\text { map } \\
\text { units }\end{array}$ & Description & $\begin{array}{l}\text { Depth to top } \\
\text { of interval } \\
\text { (feet) }\end{array}$ & $\begin{array}{l}\text { Depth to bottom } \\
\text { of interval } \\
\text { (feet) }\end{array}$ & $\begin{array}{l}\text { Thickness } \\
\text { (feet) }\end{array}$ \\
\hline \multirow[b]{2}{*}{ Kps } & $\begin{array}{l}\text { Moist, medium dense, bluish gray and greenish gray, fine to coarse, WELL } \\
\text { GRADED GRAVEL WITH SAND, estimated } 30-45 \% \text { sand, rounded to sub- } \\
\text { rounded gravel, weak to strong cementation }\end{array}$ & 296 & 300 & 4 \\
\hline & $\begin{array}{l}\text { Wet, greenish gray, fine to coarse, SILTY GRAVEL, estimated } 15-25 \% \text { fines, } \\
\text { estimated } 15-25 \% \text { fine to coarse sand, rounded to subrounded gravel }\end{array}$ & 300 & 302 & 2 \\
\hline \multirow{2}{*}{ bedrock } & Weathered bedrock (D. Powers, USGS, written commun., 2012) & 303.5 & 316 & 12.5 \\
\hline & Metatonalite (J.W. Horton, USGS, written commun., 2012) & 316 & 326 & 10 \\
\hline
\end{tabular}

Appendix 1. Lithologic descriptions.-Continued

Site name: DC2 (from Otton, 1955)

Altitude: 19.26 feet Total depth: 400 feet

Latitude / Longitude: $38^{\circ} 54^{\prime} 35.01^{\prime \prime} \mathrm{N} / 76^{\circ} 56^{\prime} 16.97^{\prime \prime} \mathrm{W}$

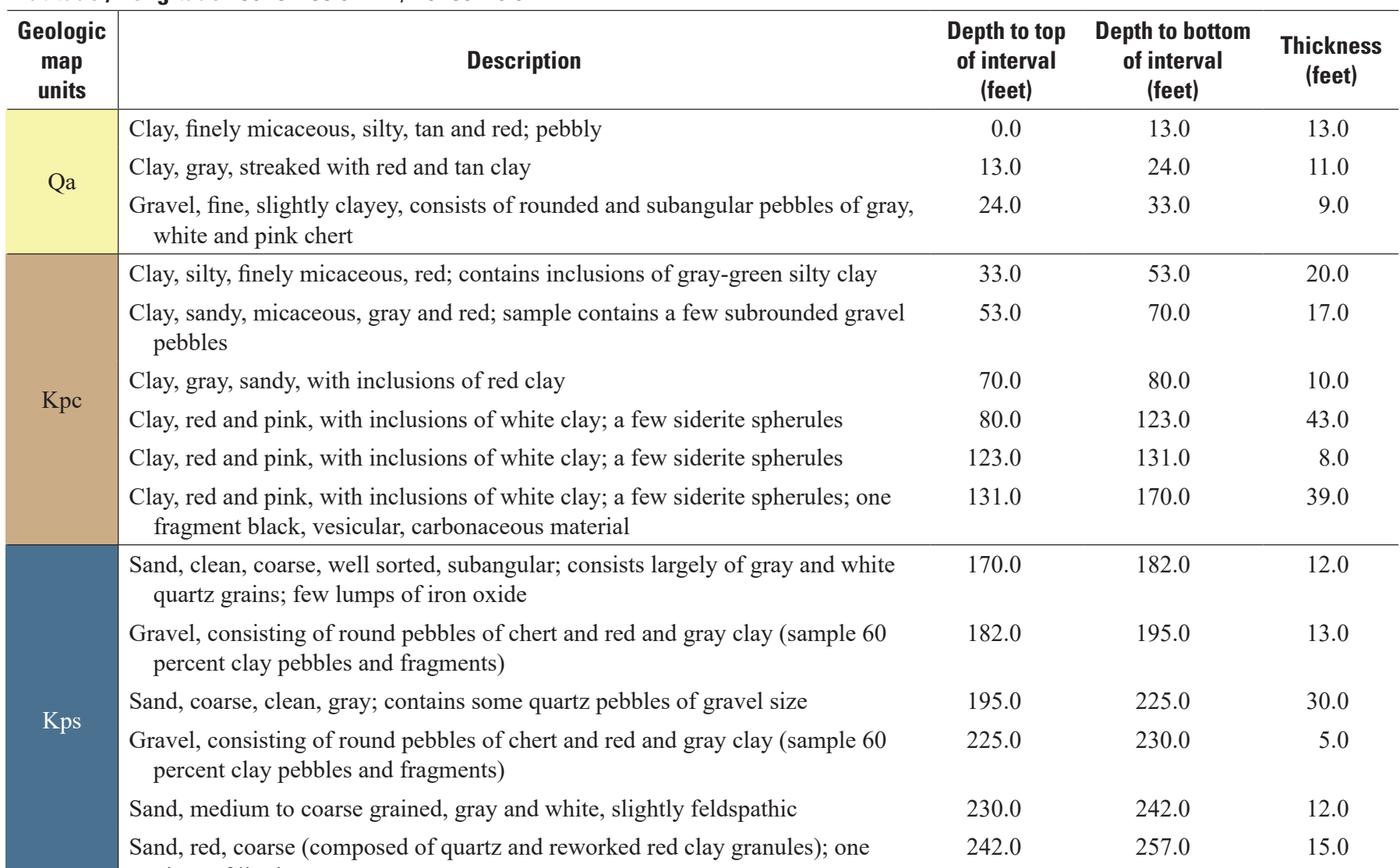
piece of lignite 
Appendix 1. Lithologic descriptions.-Continued

\section{Site name: DC2 (from Otton, 1955)}

Altitude: 19.26 feet Total depth: 400 feet

Latitude / Longitude: $38^{\circ} 54^{\prime} 35.01^{\prime \prime} \mathrm{N} / 76^{\circ} 56^{\prime} 16.97^{\prime \prime} \mathrm{W}$

\begin{tabular}{|c|c|c|c|c|}
\hline $\begin{array}{c}\text { Geologic } \\
\text { map } \\
\text { units }\end{array}$ & Description & $\begin{array}{l}\text { Depth to top } \\
\text { of interval } \\
\text { (feet) }\end{array}$ & $\begin{array}{l}\text { Depth to bottom } \\
\text { of interval } \\
\text { (feet) }\end{array}$ & $\begin{array}{l}\text { Thickness } \\
\text { (feet) }\end{array}$ \\
\hline \multirow{7}{*}{ Kps } & $\begin{array}{l}\text { Sand, red-gray, fine to medium (quartz sand with associated red clays granules); } \\
\text { few pellets lignitic material }\end{array}$ & 257.0 & 271.0 & 14.0 \\
\hline & $\begin{array}{l}\text { Sand, gray-white, medium grained, angular; some pyrite and marcasite; few } \\
\text { pieces of lignite }\end{array}$ & 271.0 & 295.0 & 24.0 \\
\hline & Clay, silty, red, with associated fine gravel & 295.0 & 318.0 & 23.0 \\
\hline & $\begin{array}{l}\text { Sand, medium to coarse grained, clean, gray; contains associated red clay inclu- } \\
\text { sions }\end{array}$ & 318.0 & 340.0 & 22.0 \\
\hline & $\begin{array}{l}\text { Clay, red and gray; consists of rounded clay lumps and some rounded quartz or } \\
\text { chert pebbles }\end{array}$ & 340.0 & 345.0 & 5.0 \\
\hline & Sand, medium grained, subrounded, clean, gray; a few pieces of marcasite & 345.0 & 354.0 & 9.0 \\
\hline & $\begin{array}{l}\text { Gravel, fine, red and gray (sample consists of } 50 \text { percent quartz pebbles and } 50 \\
\text { percent rounded clay pebbles) }\end{array}$ & 354.0 & 377.0 & 23.0 \\
\hline bedrock & $\begin{array}{l}\text { Clay, dull-brown and gray; pebbles of quartz and pieces of green schist or phyl- } \\
\text { lite }\end{array}$ & 377.0 & 400.0 & 23.0 \\
\hline
\end{tabular}

Appendix 1. Lithologic descriptions.-Continued

Site name: D.C. Aquatic Resource Center PW-2 (from HSI Geotrans, Inc., 1998)

Altitude: 16 feet Total depth: 398 feet

Latitude / Longitude: $38^{\circ} 52^{\prime} 42.01^{\prime \prime} \mathrm{N} / 76^{\circ} 58^{\prime} 09.96^{\prime \prime} \mathrm{W}$

\begin{tabular}{|c|c|c|c|c|}
\hline $\begin{array}{l}\text { Geologic } \\
\text { map } \\
\text { units }\end{array}$ & Description & $\begin{array}{l}\text { Depth to top } \\
\text { of interval } \\
\text { (feet) }\end{array}$ & $\begin{array}{l}\text { Depth to bottom } \\
\text { of interval } \\
\text { (feet) }\end{array}$ & $\begin{array}{l}\text { Thickness } \\
\text { (feet) }\end{array}$ \\
\hline \multirow{2}{*}{$\operatorname{dgf}$} & Dark brown silty clay with brick fragments & 0.0 & 13.0 & 13.0 \\
\hline & No sample & 13.0 & 14.0 & 1.0 \\
\hline \multirow{6}{*}{$\begin{array}{l}\text { Qa } \\
\text { and } \\
\text { Qt }\end{array}$} & $\begin{array}{l}\text { Dark greenish-gray clayey silt, abundant carbonaceous material, some roots, } \\
\text { trace sand }\end{array}$ & 14.0 & 21.0 & 7.0 \\
\hline & Dark greenish-gray clayey silt, some carbonaceous material, trace roots & 28.0 & 38.0 & 10.0 \\
\hline & Light to medium brown and gray silty sand, some clay, loose, wet & 38.0 & 40.0 & 2.0 \\
\hline & Yellow-brown, poorly sorted gravel and sand & 40.0 & 46.0 & 6.0 \\
\hline & Light to medium gray sandy clay layer & 46.0 & 49.0 & 3.0 \\
\hline & Medium gray gravel with fine to coarse sand & 49.0 & 58.0 & 9.0 \\
\hline $\mathrm{Kpc}$ & Red clay, with traces of sand and gray clay, moist & 136.0 & 168.0 & 32.0 \\
\hline \multirow{5}{*}{ Kps } & Coarse sand with traces of gray clay & 168.0 & 193.0 & 25.0 \\
\hline & Gray clay with some sand & 193.0 & 202.0 & 9.0 \\
\hline & Coarse sand and clay, lignite runner & 202.0 & 205.0 & 3.0 \\
\hline & Gray sandy clay & 205.0 & 213.0 & 8.0 \\
\hline & Coarse sand and clay & 213.0 & 242.0 & 29.0 \\
\hline
\end{tabular}


Appendix 1. Lithologic descriptions.-Continued

Site name: D.C. Aquatic Resource Center PW-2 (from HSI Geotrans, Inc., 1998)

Altitude: 16 feet Total depth: 398 feet

Latitude / Longitude: $38^{\circ} 52^{\prime} 42.01^{\prime \prime} \mathrm{N} / 76^{\circ} 58^{\prime} 09.96^{\prime \prime} \mathrm{W}$

\begin{tabular}{|c|c|c|c|c|}
\hline $\begin{array}{c}\text { Geologic } \\
\text { map } \\
\text { units }\end{array}$ & Description & $\begin{array}{l}\text { Depth to top } \\
\text { of interval } \\
\text { (feet) }\end{array}$ & $\begin{array}{c}\text { Depth to bottom } \\
\text { of interval } \\
\text { (feet) }\end{array}$ & $\begin{array}{c}\text { Thickness } \\
\text { (feet) }\end{array}$ \\
\hline \multirow{8}{*}{ Kps } & Gray clay with some sand & 242.0 & 251.0 & 9.0 \\
\hline & Coarse sand & 251.0 & 262.0 & 11.0 \\
\hline & Clay with trace sand & 262.0 & 293.0 & 31.0 \\
\hline & Sand & 293.0 & 312.0 & 19.0 \\
\hline & Sand & 317.0 & 323.0 & 6.0 \\
\hline & Clay & 323.0 & 330.0 & 7.0 \\
\hline & Sand and clay & 330.0 & 340.0 & 10.0 \\
\hline & Sticky clay & 340.0 & 355.0 & 15.0 \\
\hline
\end{tabular}

Appendix 1. Lithologic descriptions.-Continued

Site name: MW-2 (from DCWRRC, 1993a)

Altitude: 82.35 feet Total depth: 47 feet

Latitude / Longitude: $38^{\circ} 54^{\prime} 23.00^{\prime \prime} \mathrm{N} / 77^{\circ} 00^{\prime} 44.97^{\prime \prime} \mathrm{W}$

\begin{tabular}{|c|c|c|c|c|}
\hline $\begin{array}{l}\text { Geologic } \\
\text { map } \\
\text { units }\end{array}$ & Description & $\begin{array}{l}\text { Depth to top } \\
\text { of interval } \\
\text { (feet) }\end{array}$ & $\begin{array}{l}\text { Depth to bottom } \\
\text { of interval } \\
\text { (feet) }\end{array}$ & $\begin{array}{c}\text { Thickness } \\
\text { (feet) }\end{array}$ \\
\hline \multirow{2}{*}{$\operatorname{dgf}$} & Brown, sandy, damp, fill material & 0.0 & 6.0 & 6.0 \\
\hline & About 7' pieces of brick & 6.0 & 7.5 & 1.5 \\
\hline \multirow{5}{*}{ Qte } & No sample & 7.5 & 10.0 & 2.5 \\
\hline & Brown, dry, medium grained sand & 10.0 & 12.0 & 2.0 \\
\hline & Brown, damp sand with some gravel & 15.0 & 17.0 & 2.0 \\
\hline & No sample & 17.0 & 20.0 & 3.0 \\
\hline & Brown, dry gravelly sand & 20.0 & 22.0 & 2.0 \\
\hline \multirow{5}{*}{ Kpc } & No sample & 22.0 & 25.0 & 3.0 \\
\hline & No sample & 32.0 & 35.0 & 3.0 \\
\hline & Gray, dry clay with trace of silty sand & 35.0 & 37.0 & 2.0 \\
\hline & No sample & 37.0 & 40.0 & 3.0 \\
\hline & Gray, damp silty clay changes to wet sand & 40.0 & 42.0 & 2.0 \\
\hline \multirow{2}{*}{ Kps } & No sample & 42.0 & 45.0 & 3.0 \\
\hline & Gray clayey medium grained sand & 45.0 & 47.0 & 2.0 \\
\hline
\end{tabular}


Appendix 1. Lithologic descriptions.-Continued

Site name: PG Cc 13 (from Cooke and others, 1952)

Altitude: 209.65 feet Total depth: 134 feet

Latitude / Longitude: $38^{\circ} 58^{\prime} 30.00^{\prime \prime} \mathrm{N} / 76^{\circ} 59^{\prime} 43.97^{\prime \prime} \mathrm{W}$

\begin{tabular}{|c|c|c|c|c|}
\hline $\begin{array}{l}\text { Geologic } \\
\text { map } \\
\text { units }\end{array}$ & Description & $\begin{array}{l}\text { Depth to top } \\
\text { of interval } \\
\text { (feet) }\end{array}$ & $\begin{array}{l}\text { Depth to bottom } \\
\text { of interval } \\
\text { (feet) }\end{array}$ & $\begin{array}{l}\text { Thickness } \\
\text { (feet) }\end{array}$ \\
\hline \multirow{6}{*}{ Kpc } & Sand, clayey, grayish-orange to light brown & 0.0 & 10.0 & 10.0 \\
\hline & Clay, silty, grayish-orange, finely micaceous & 10.0 & 15.0 & 5.0 \\
\hline & Clay, silty, grayish-orange and dark yellow orange, micaceous; lignite fragments & 15.0 & 20.0 & 5.0 \\
\hline & Clay, dense, tough, grayish orange to pale yellowish-orange & 20.0 & 25.0 & 5.0 \\
\hline & Clay, sandy, grayish orange to very pale orange & 25.0 & 30.0 & 5.0 \\
\hline & Clay, silty, soft, very pale orange to white & 30.0 & 35.0 & 5.0 \\
\hline \multirow{8}{*}{ bedrock } & $\begin{array}{l}\text { Rock, schistose, soft, clayey and partially quartzitic, light olive-gray to greenish } \\
\text { gray mica }\end{array}$ & 35.0 & 40.0 & 5.0 \\
\hline & $\begin{array}{l}\text { Rock, same as above, but somewhat darker in color, mica smaller, quartz grains } \\
\text { less common }\end{array}$ & 40.0 & 45.0 & 5.0 \\
\hline & Rock, same as above, few fragments feldspar, pink & 45.0 & 50.0 & 5.0 \\
\hline & Rock, schistose, loose mica flakes, fine quartz grains & 50.0 & 55.0 & 5.0 \\
\hline & No sample, driller reports "mica rock" & 55.0 & 90.0 & 35.0 \\
\hline & Rock, schistose, similar to above sample & 90.0 & 100.0 & 10.0 \\
\hline & No sample, driller reports "mica rock" & 100.0 & 132.0 & 32.0 \\
\hline & Rock, schistose, loose mica flakes, fine quartz grains & 132.0 & 134.0 & 2.0 \\
\hline
\end{tabular}

Appendix 1. Lithologic descriptions.-Continued

Site name: PG Cd 9 (from Cooke and others, 1952)

Altitude: 135.4 feet Total depth: 160 feet

Latitude / Longitude: $38^{\circ} 56^{\prime} 00.01^{\prime \prime} \mathrm{N} / 76^{\circ} 51^{\prime} 57.97^{\prime \prime} \mathrm{W}$

\begin{tabular}{|c|c|c|c|c|}
\hline $\begin{array}{l}\text { Geologic } \\
\text { map } \\
\text { units }\end{array}$ & Description & $\begin{array}{l}\text { Depth to top } \\
\text { of interval } \\
\text { (feet) }\end{array}$ & $\begin{array}{c}\text { Depth to bottom } \\
\text { of interval } \\
\text { (feet) }\end{array}$ & $\begin{array}{l}\text { Thickness } \\
\text { (feet) }\end{array}$ \\
\hline \multirow{11}{*}{ Kpc } & No Sample & 0.0 & 10.0 & 10.0 \\
\hline & Clay, silty, red-ochre & 10.0 & 20.0 & 10.0 \\
\hline & Silt, sandy, cream-tan, slightly micaceous & 20.0 & 30.0 & 10.0 \\
\hline & Silt, sandy, pink-red & 30.0 & 40.0 & 10.0 \\
\hline & Silt, sandy, pink-red with dark nodules & 40.0 & 50.0 & 10.0 \\
\hline & Clay, sandy, buff-cream & 50.0 & 60.0 & 10.0 \\
\hline & No Sample & 60.0 & 70.0 & 10.0 \\
\hline & $\begin{array}{l}\text { Sand, medium to coarse, subangular, translucent and transparent, some grains } \\
\text { pink and yellow quartz; some tripoli }\end{array}$ & 70.0 & 80.0 & 10.0 \\
\hline & $\begin{array}{l}\text { Sand, well-sorted, medium-grained, angular, pink-yellow; contains few black } \\
\text { pellets of siderite (?) }\end{array}$ & 80.0 & 90.0 & 10.0 \\
\hline & $\begin{array}{l}\text { Sand, coarse, angular, moderately well-sorted, pink-white; contains some iron } \\
\text { oxides }\end{array}$ & 90.0 & 100.0 & 10.0 \\
\hline & Buff-white silty clay; contains some pellets of dark material & 100.0 & 110.0 & 10.0 \\
\hline
\end{tabular}


Appendix 1. Lithologic descriptions.-Continued

Site name: PG Cd 9 (from Cooke and others, 1952)

Altitude: 135.4 feet Total depth: 160 feet

Latitude / Longitude: $38^{\circ} 56^{\prime} 00.01^{\prime \prime} \mathrm{N} / 76^{\circ} 51^{\prime} 57.97^{\prime \prime} \mathrm{W}$

\begin{tabular}{|c|c|c|c|c|}
\hline $\begin{array}{l}\text { Geologic } \\
\text { map } \\
\text { units }\end{array}$ & Description & $\begin{array}{l}\text { Depth to top } \\
\text { of interval } \\
\text { (feet) }\end{array}$ & $\begin{array}{l}\text { Depth to bottom } \\
\text { of interval } \\
\text { (feet) }\end{array}$ & $\begin{array}{c}\text { Thickness } \\
\text { (feet) }\end{array}$ \\
\hline \multirow{5}{*}{ Kpc } & Red-ochre sandy clay & 110.0 & 120.0 & 10.0 \\
\hline & Red-ochre sandy clay; contains some quartz fragments & 120.0 & 130.0 & 10.0 \\
\hline & Buff-white, slightly sandy clay & 130.0 & 140.0 & 10.0 \\
\hline & Red, very sandy clay & 140.0 & 150.0 & 10.0 \\
\hline & No samples & 160.0 & 185.0 & 25.0 \\
\hline
\end{tabular}

Appendix 1. Lithologic descriptions.-Continued

Site name: PG Dc 1 (from Cooke and others, 1952)

Altitude: 290 feet Total depth: 365 feet

Latitude / Longitude: $38^{\circ} 51^{\prime} 19^{\prime \prime} \mathrm{N} / 76^{\circ} 56^{\prime} 05^{\prime \prime} \mathrm{W}$

\begin{tabular}{|c|c|c|c|c|}
\hline $\begin{array}{c}\text { Geologic } \\
\text { map } \\
\text { units }\end{array}$ & Description & $\begin{array}{c}\text { Depth to top } \\
\text { of interval } \\
\text { (feet) }\end{array}$ & $\begin{array}{c}\text { Depth to bottom } \\
\text { of interval } \\
\text { (feet) }\end{array}$ & $\begin{array}{c}\text { Thickness } \\
\text { (feet) }\end{array}$ \\
\hline \multirow{2}{*}{ Ttu } & Pliocene (?) deposits: & & & \\
\hline & Gravel & 0 & 26 & 26 \\
\hline \multirow{2}{*}{$\begin{array}{l}\text { Tc } \\
\text { and } \\
\text { Ta }\end{array}$} & Calvert Formation and Aquia greensand: & & & \\
\hline & "Quicksand" & 26 & 29 & 3 \\
\hline \multirow{4}{*}{$\mathrm{TKb}$} & Brightseat Formation and/or Monmouth Formation: & & & \\
\hline & Shells & 89 & 98 & 9 \\
\hline & "Mud," black & 98 & 110 & 12 \\
\hline & Shells & 110 & 119 & 9 \\
\hline \multirow{5}{*}{$\begin{array}{l}\mathrm{Km} \\
\text { and } \\
\mathrm{Kpc}\end{array}$} & Clay, yellow & & & \\
\hline & Clay, blue & & & \\
\hline & Clay, red & 119 & 355 & 236 \\
\hline & Sand & 355 & 365 & 10 \\
\hline & Clay, blue & At 365 & -- & -- \\
\hline
\end{tabular}


Appendix 1. Lithologic descriptions.-Continued

Site name: PG Dc 3 (from Cooke and others, 1952)

Altitude: 290 feet Total depth: 388 feet

Latitude / Longitude: $38^{\circ} 50^{\prime} 24^{\prime \prime} \mathrm{N} / 76^{\circ} 56^{\prime} 32^{\prime \prime} \mathrm{W}$

\begin{tabular}{|c|c|c|c|c|}
\hline $\begin{array}{l}\text { Geologic } \\
\text { map } \\
\text { units }\end{array}$ & Description & $\begin{array}{l}\text { Depth to top } \\
\text { of interval } \\
\text { (feet) }\end{array}$ & $\begin{array}{l}\text { Depth to bottom } \\
\text { of interval } \\
\text { (feet) }\end{array}$ & $\begin{array}{c}\text { Thickness } \\
\text { (feet) }\end{array}$ \\
\hline \multirow{3}{*}{ Ttu } & Pliocene (?) deposits: & & & \\
\hline & Clay, brown, and gravel & 0 & 25 & 25 \\
\hline & Gravel & 25 & 55 & 30 \\
\hline \multirow{2}{*}{$\mathrm{Tc}$} & Calvert Formation: & & & \\
\hline & Clay, yellow & 55 & 70 & 15 \\
\hline \multirow{5}{*}{$\begin{array}{l}\mathrm{Tc} \\
\text { and } \\
\mathrm{Ta}\end{array}$} & Calvert Formation and Aquia greensand: & & & \\
\hline & Marl & 70 & 95 & 25 \\
\hline & Marl and shells & 95 & 113 & 18 \\
\hline & Rock & 113 & 114 & 1 \\
\hline & Marl and shells & 114 & 123 & 9 \\
\hline \multirow{3}{*}{$\mathrm{TKb}$} & Brightseat Formation and/or Monmouth Formation: & & & \\
\hline & Rock and shells & 123 & 125 & 2 \\
\hline & Marl & & 171 & 46 \\
\hline \multirow{3}{*}{$\begin{array}{l}\mathrm{Km} \\
\text { and } \\
\mathrm{Kpc}\end{array}$} & Magothy (?) and Patapsco Formations: & & & \\
\hline & Clay & 171 & 377 & 206 \\
\hline & Sand & 377 & 388 & 11 \\
\hline
\end{tabular}

Appendix 1. Lithologic descriptions.-Continued

Site name: PG Dc 4 (from Cooke and others, 1952)

Altitude: 250 feet Total depth: 620 feet

Latitude / Longitude: $38^{\circ} 50^{\prime} 47^{\prime \prime} \mathrm{N} / 76^{\circ} 57^{\prime} 10^{\prime \prime} \mathrm{W}$

\begin{tabular}{|c|c|c|c|c|}
\hline $\begin{array}{l}\text { Geologic } \\
\text { map } \\
\text { units }\end{array}$ & Description & $\begin{array}{l}\text { Depth to top } \\
\text { of interval } \\
\text { (feet) }\end{array}$ & $\begin{array}{l}\text { Depth to bottom } \\
\text { of interval } \\
\text { (feet) }\end{array}$ & $\begin{array}{c}\text { Thickness } \\
\text { (feet) }\end{array}$ \\
\hline \multirow{2}{*}{ Ttu } & Pliocene (?) deposits: & & & \\
\hline & Clay, sand, and gravel & 0 & 30 & 30 \\
\hline \multirow{3}{*}{$\begin{array}{c}\mathrm{Tc}, \mathrm{Ta}, \\
\text { and(or) } \\
\mathrm{TKb}\end{array}$} & $\begin{array}{l}\text { Calvert Formation, Aquia greensand, Brightseat Formation and/or Monmouth } \\
\text { Formation: }\end{array}$ & & & \\
\hline & Clay & 30 & 60 & 30 \\
\hline & Marl & 60 & 240 & 180 \\
\hline \multirow{2}{*}{$\mathrm{Km}$} & Magothy (?) Formation: & & & \\
\hline & Sand, fine (water) & 240 & 252 & 12 \\
\hline \multirow{6}{*}{ Kpc } & Potomac Group: & & & \\
\hline & Clay, variegated & 252 & 370 & 118 \\
\hline & Clay, sandy & 370 & 406 & 36 \\
\hline & Clay, tough & 406 & 458 & 52 \\
\hline & Sand, medium fine, gray (water) & 458 & 475 & 17 \\
\hline & Clay, tough & 475 & 620 & 145 \\
\hline
\end{tabular}


Appendix 1. Lithologic descriptions.-Continued

PG Eb 1 (from Cooke and others, 1952)

Altitude: 14.3 feet Total depth: 603 feet

Latitude / Longitude: $38^{\circ} 48^{\prime} 42.00^{\prime \prime} \mathrm{N} / 77^{\circ} 00^{\prime} 21.97^{\prime \prime} \mathrm{W}$

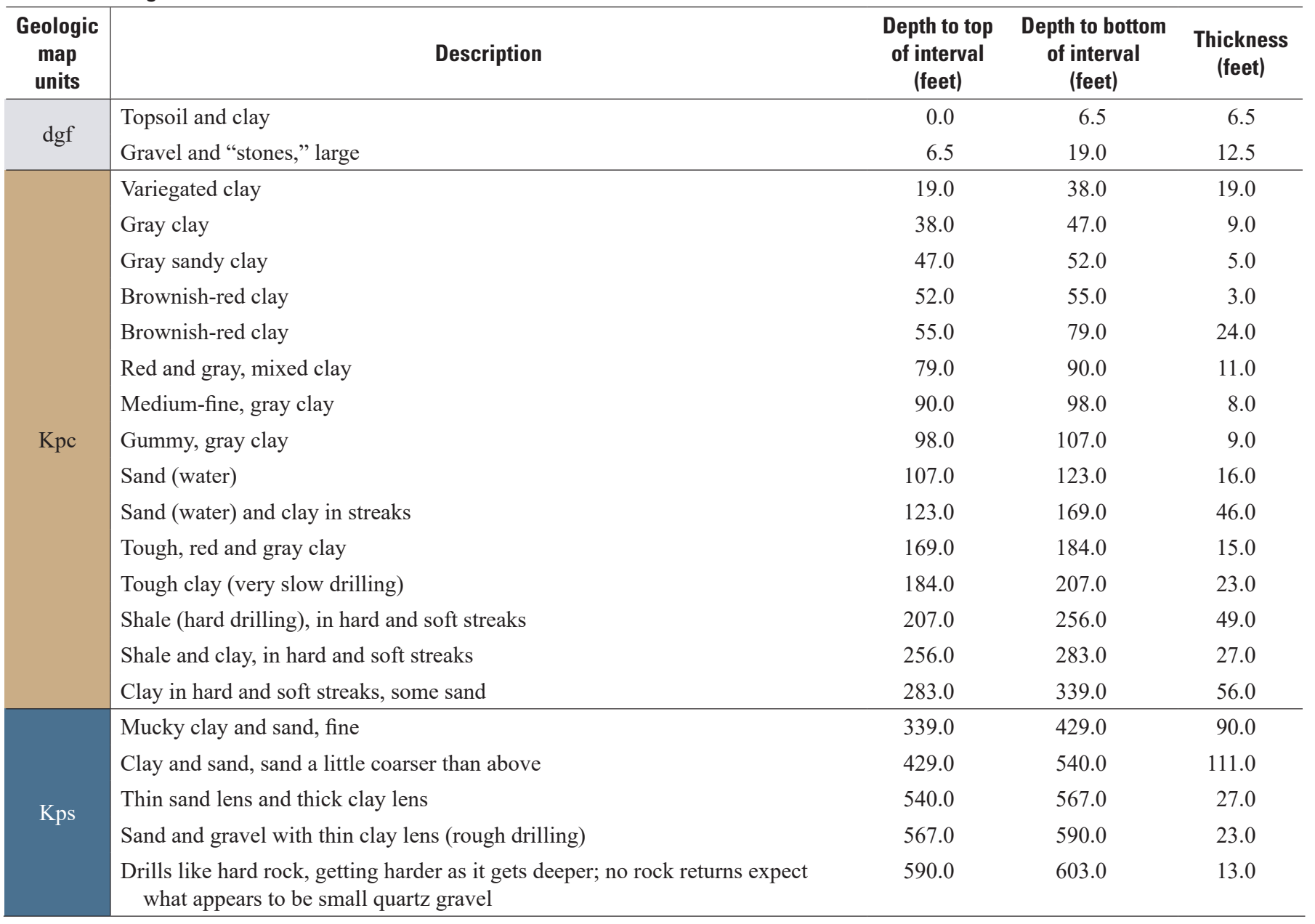


Appendix 1. Lithologic descriptions.-Continued

Site name: SAS-001 (described by Camp Dresser \& McKee Inc./Hatch Mott MacDonald, written commun., 2008)

Altitude: 8.4 feet Total depth: 250 feet

Latitude / Longitude: $38^{\circ} 52^{\prime} 20.87^{\prime \prime} \mathrm{N} / 77^{\circ} 00^{\prime} 15.49^{\prime \prime} \mathrm{W}$

Core used in section C-C'

\begin{tabular}{|c|c|c|c|c|}
\hline $\begin{array}{c}\text { Geologic } \\
\text { map } \\
\text { units }\end{array}$ & Description & $\begin{array}{l}\text { Depth to top } \\
\text { of interval } \\
\text { (feet) }\end{array}$ & $\begin{array}{l}\text { Depth to bottom } \\
\text { of interval } \\
\text { (feet) }\end{array}$ & $\begin{array}{l}\text { Thickness } \\
\text { (feet) }\end{array}$ \\
\hline \multirow{20}{*}{ Qa } & No sample & 0.0 & 8.0 & 8.0 \\
\hline & $\begin{array}{l}\text { Moist, very soft, brown, silt. Trace of clay. Trace of fine sand at } 16 \text { feet. Dark } \\
\text { brown with wood at } 17 \text { feet. }\end{array}$ & 8.0 & 18.0 & 10.0 \\
\hline & $\begin{array}{l}\text { Wet, dark brown, fine sand, some silt, trace clay, trace gravel, slightly organic, } \\
\text { frequent fragments of partially decomposed wood. }\end{array}$ & 18.0 & 20.0 & 2.0 \\
\hline & Wet, reddish brown, poorly graded fine to medium sand, trace silt. & 20.0 & 23.0 & 3.0 \\
\hline & Wet, light gray and brown silt, with 2-inch clay layers, trace fine sand. & 23.0 & 25.0 & 2.0 \\
\hline & Wet, light gray and brown fine sand and silt, trace fine subrounded gravel. & 25.0 & 26.0 & 1.0 \\
\hline & Wet, light gray clay, some silt. & 26.0 & 28.0 & 2.0 \\
\hline & Wet, light gray and brown fine sand, some clay, trace silt. & 28.0 & 31.0 & 3.0 \\
\hline & $\begin{array}{l}\text { Wet, green-gray, fine to medium sand, and fine to coarse subangular gravel, } \\
\text { some silt. }\end{array}$ & 31.0 & 33.0 & 2.0 \\
\hline & $\begin{array}{l}\text { Wet, green-gray, well graded fine to coarse subangular gravel with fine to me- } \\
\text { dium sand, trace silt. }\end{array}$ & 31.0 & 35.0 & 4.0 \\
\hline & $\begin{array}{l}\text { Wet, orange-red, poorly graded fine to coarse sand, little fine to medium suban- } \\
\text { gular to subrounded gravel, trace silt. }\end{array}$ & 35.0 & 37.0 & 2.0 \\
\hline & $\begin{array}{l}\text { Wet, orange-red, well graded fine to coarse subangular to rounded gravel, some } \\
\text { fine to coarse sand, trace silt. }\end{array}$ & 37.0 & 45.0 & 8.0 \\
\hline & Wet, blue-green, fine sand, trace silt. & 45.0 & 46.0 & 1.0 \\
\hline & $\begin{array}{l}\text { Wet, gray, medium to coarse, subrounded gravel, some gray-green stiff clay with } \\
\text { angular cobbles, little fine sand. }\end{array}$ & 46.0 & 48.0 & 2.0 \\
\hline & Wet, hard, blue mottled red, clay, trace fine sand. & 48.0 & 50.0 & 2.0 \\
\hline & Wet, hard, blue mottled red, silt, trace clay, trace fine sand. & 50.0 & 55.0 & 5.0 \\
\hline & Wet, blue-gray, fine to medium sand, little silt. & 55.0 & 57.5 & 2.5 \\
\hline & Wet, blue-gray, clayey fine sand, trace silt, occasional seams of stiff clay. & 57.5 & 63.0 & 5.5 \\
\hline & Wet, blue-gray, fine to medium sand, little silt. & 63.0 & 68.0 & 5.0 \\
\hline & $\begin{array}{l}\text { Wet, blue-gray, poorly graded fine to coarse subangular sand, trace fine gravel, } \\
\text { trace silt, trace clay, frequent seams of clay. Less clay below } 75 \text { feet. }\end{array}$ & 68.0 & 80.0 & 12.0 \\
\hline \multirow{8}{*}{ Kps } & Wet, blue-gray, medium to coarse sand, trace silt, trace clay. & 80.0 & 82.0 & 2.0 \\
\hline & Wet, blue-gray, fine to medium sand, little to some clay. & 82.0 & 85.0 & 3.0 \\
\hline & Wet, blue-gray, poorly graded fine to coarse sand, trace mica. & 85.0 & 90.0 & 5.0 \\
\hline & Wet, blue-gray, fine to medium sand, little clay, trace mica. & 90.0 & 94.0 & 4.0 \\
\hline & $\begin{array}{l}\text { Wet, blue-gray, fine to medium sand, trace silt, trace fine, subangular gravel, } \\
\text { traces of weak cementation. }\end{array}$ & 94.0 & 99.0 & 5.0 \\
\hline & Wet, blue-gray, clayey fine to medium sand, little clay, trace silt. & 99.0 & 100.0 & 1.0 \\
\hline & Moist to wet, hard, light gray-blue, silt and fine to medium sand, little clay. & 100.0 & 105.0 & 5.0 \\
\hline & Moist to wet, hard, laminated brown, gray and red, clay, some fine to medium & 105.0 & 110.0 & 5.0 \\
\hline
\end{tabular}

sand. 
Appendix 1. Lithologic descriptions.-Continued

Site name: SAS-001 (described by Camp Dresser \& McKee Inc./Hatch Mott MacDonald, written commun., 2008)

Altitude: 8.4 feet Total depth: 250 feet

Latitude / Longitude: $38^{\circ} 52^{\prime} 20.87^{\prime \prime} \mathrm{N} / 77^{\circ} 00^{\prime} 15.49^{\prime \prime} \mathrm{W}$

Core used in section C-C'

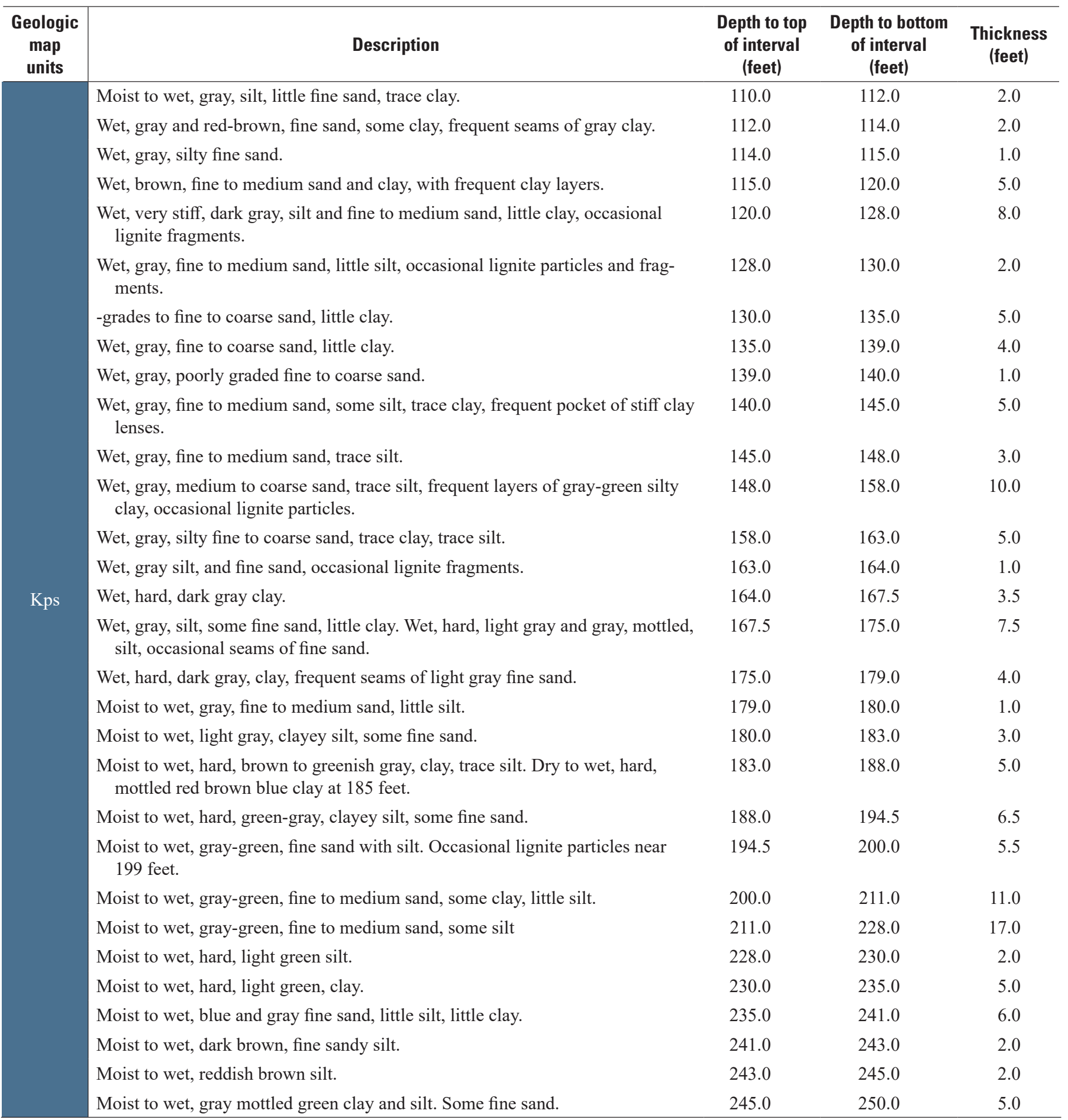


Appendix 1. Lithologic descriptions.-Continued

Site name: SAS-002 (described by C. Dieter)

Altitude: 13 feet Total Depth: 156 feet

Latitude / Longitude: $38^{\circ} 52^{\prime} 09.39^{\prime \prime} \mathrm{N} / 77^{\circ} 00^{\prime} 06.12^{\prime \prime} \mathrm{W}$

Core used in section C-C'

\begin{tabular}{|c|c|c|c|c|}
\hline $\begin{array}{l}\text { Geologic } \\
\text { map } \\
\text { units }\end{array}$ & Description & $\begin{array}{l}\text { Depth to top } \\
\text { of interval } \\
\text { (feet) }\end{array}$ & $\begin{array}{c}\text { Depth to bottom } \\
\text { of interval } \\
\text { (feet) }\end{array}$ & $\begin{array}{l}\text { Thickness } \\
\text { (feet) }\end{array}$ \\
\hline \multirow{7}{*}{ Qa } & No recovery & 0.0 & 9.0 & 9.0 \\
\hline & Dark brownish-gray clayey silt with organic matter & 9.0 & 19.0 & 10.0 \\
\hline & Medium to light brown silty clay. Soft, moist, with organic matter & 19.0 & 22.0 & 3.0 \\
\hline & Medium yellowish brown to dark chocolate brown clay with organic matter & 22.0 & 25.5 & 3.5 \\
\hline & Sandy clay & 25.5 & 26.0 & 0.5 \\
\hline & No recovery & 26.0 & 28.0 & 2.0 \\
\hline & Gravelly sand. (Gravels up to 2 -inch length of long diameter) & 28.0 & 33.0 & 5.0 \\
\hline \multirow{8}{*}{ Kpc } & Mottled light gray, pink, and yellowish brown silty clay & 33.0 & 36.0 & 3.0 \\
\hline & Red clay with light gray mottling (stiff, tight clay) & 36.0 & 56.0 & 20.0 \\
\hline & Red silty clay & 56.0 & 57.5 & 1.5 \\
\hline & Red clay with a little light gray mottling and silty layers & 57.5 & 61.0 & 3.5 \\
\hline & Red silty clay & 61.0 & 72.5 & 11.5 \\
\hline & Red very fine sand, well sorted & 72.5 & 75.5 & 3.0 \\
\hline & Red silt with zones that are more clayey and zones that are more sandy silt. & 75.5 & 96.0 & 20.5 \\
\hline & $\begin{array}{l}\text { Reddish-brown silt with zones that are more clayey and zones that are more } \\
\text { sandy silt. }\end{array}$ & 96.0 & 104.0 & 8.0 \\
\hline \multirow{8}{*}{ Kps } & Medium brownish-gray clayey fine-grained sand & 104.0 & 106.0 & 2.0 \\
\hline & $\begin{array}{l}\text { Medium-grained, poorly sorted, sand. Becomes more clayey with some organic } \\
\text { matter at } 114.5 \text { feet }\end{array}$ & 106.0 & 115.0 & 9.0 \\
\hline & $\begin{array}{l}\text { Medium-grained sand with a high percentage of organic matter (lignitized } \\
\text { woody pieces) }\end{array}$ & 115.0 & 116.0 & 1.0 \\
\hline & $\begin{array}{l}\text { Fine-grained moderately well sorted clayey (tacky) sand with organic matter. } \\
\text { Random medium gray clayey pockets. }\end{array}$ & 116.0 & 131.0 & 15.0 \\
\hline & Coarse sand with clay and high percentage of organic matter & 131.0 & 133.0 & 2.0 \\
\hline & $\begin{array}{l}\text { Poorly sorted, subangular, coarse-grained sand. Some } 0.75 \text {-inch diameter } \\
\text { cobbles at about } 140 \text { feet }\end{array}$ & 133.0 & 149.5 & 16.5 \\
\hline & Coarse sand with high clay content & 149.5 & 150.5 & 1.0 \\
\hline & Medium-grained, moderately well sorted subangular sand & 150.5 & 156.0 & 5.5 \\
\hline
\end{tabular}


Appendix 1. Lithologic descriptions.-Continued

Site name: SAS-006 (described by C. Dieter)

Altitude: 12.3 feet Total depth: $182 \mathrm{feet}$

Latitude / Longitude: $38^{\circ} 53^{\prime} 01.39^{\prime \prime} \mathrm{N} / 76^{\circ} 58^{\prime} 16.65^{\prime \prime} \mathrm{W}$

Core used in section D-D'

\begin{tabular}{|c|c|c|c|c|}
\hline $\begin{array}{c}\text { Geologic } \\
\text { map } \\
\text { units }\end{array}$ & Description & $\begin{array}{l}\text { Depth to top } \\
\text { of interval } \\
\text { (feet) }\end{array}$ & $\begin{array}{c}\text { Depth to bottom } \\
\text { of interval } \\
\text { (feet) }\end{array}$ & $\begin{array}{l}\text { Thickness } \\
\text { (feet) }\end{array}$ \\
\hline \multirow[b]{2}{*}{$\operatorname{dgf}$} & No recovery & 0.0 & 10.0 & 10.0 \\
\hline & $\begin{array}{l}\text { Dark brown, poorly-sorted, soft, clayey silt. Fragments of glass, pebbles, sand, } \\
\text { mica }\end{array}$ & 10.0 & 17.0 & 7.0 \\
\hline \multirow{4}{*}{ Qa } & No recovery & 17.0 & 27.0 & 10.0 \\
\hline & Fine- to medium-grained sand with dark gray clay inclusions & 31.0 & 34.0 & 3.0 \\
\hline & $\begin{array}{l}\text { Dark gray, soft, silty clay with gravel ( } 0.125 \text {-inch diameter) and trace mica. } \\
\text { Large dark purple-red clast (?gravel?) at } 40 \text { feet. }\end{array}$ & 34.0 & 40.0 & 6.0 \\
\hline & Poorly sorted, angular, fine- to coarse-grained sand with silt. & 40.0 & 41.5 & 1.5 \\
\hline \multirow{7}{*}{ Kрс } & Light gray with light pink soft, brittle, crumbly silty clay. & 57.0 & 59.5 & 2.5 \\
\hline & Light gray clay mottled with brick red silt. & 59.5 & 67.0 & 7.5 \\
\hline & Light pink and light gray mottled clay. & 67.0 & 69.0 & 2.0 \\
\hline & Pink, yellow-brown, and light gray mottled clay. & 69.0 & 77.0 & 8.0 \\
\hline & Red and light gray mottled sandy silt & 77.0 & 80.0 & 3.0 \\
\hline & $\begin{array}{l}\text { Mottled medium brown, pink-red, light gray, and yellow brown sandy, clayey, } \\
\text { silt }\end{array}$ & 80.0 & 87.0 & 7.0 \\
\hline & $\begin{array}{l}\text { Mottled medium brown, pink-red, light gray, and yellow brown, silty, sandy } \\
\text { clay. Less cohesive than } 80-87 \text { feet }\end{array}$ & 87.0 & 97.0 & 10.0 \\
\hline \multirow{7}{*}{ Kps } & $\begin{array}{l}\text { Cohesive, fine- to medium-grained clayey sand. Some zones more cohesive, } \\
\text { some zones less cohesive. }\end{array}$ & 120.0 & 123.0 & 3.0 \\
\hline & Very cohesive, slightly mottled silty clayey sand. & 123.0 & 130.0 & 7.0 \\
\hline & $\begin{array}{l}\text { Light gray, fine- to coarse-grained clayey sand. Some zones very clayey/cohe- } \\
\text { sive, some zones less clayey/cohesive. }\end{array}$ & 130.0 & 137.0 & 7.0 \\
\hline & Moderately well-sorted, subangular, medium-grained sand. & 137.0 & 140.0 & 3.0 \\
\hline & $\begin{array}{l}\text { Light gray/colored, poorly sorted, somewhat cohesive, medium- to coarse- } \\
\text { grained sand. (Slightly more cohesive from } 150-153.5 \text { feet) }\end{array}$ & 140.0 & 153.5 & 13.5 \\
\hline & Transitional fining downward from sand to silt to clay & 153.5 & 156.0 & 2.5 \\
\hline & Very fine-grained silty sand & 156.0 & 157.0 & 1.0 \\
\hline
\end{tabular}


Appendix 1. Lithologic descriptions.-Continued

Site name: SAS-006 (described by C. Dieter)

Altitude: 12.3 feet Total depth: 182 feet

Latitude / Longitude: $38^{\circ} 53^{\prime} 01.39^{\prime \prime} \mathrm{N} / 76^{\circ} 58^{\prime} 16.65^{\prime \prime} \mathrm{W}$

Core used in section D-D'

\begin{tabular}{|c|c|c|c|c|}
\hline $\begin{array}{l}\text { Geologic } \\
\text { map } \\
\text { units }\end{array}$ & Description & $\begin{array}{l}\text { Depth to top } \\
\text { of interval } \\
\text { (feet) }\end{array}$ & $\begin{array}{l}\text { Depth to bottom } \\
\text { of interval } \\
\text { (feet) }\end{array}$ & $\begin{array}{l}\text { Thickness } \\
\text { (feet) }\end{array}$ \\
\hline \multirow{7}{*}{ Kps } & Light gray and light pink, poorly sorted, mottled clayey silty sand & 157.0 & 160.0 & 3.0 \\
\hline & Light gray, fine- to medium-grained sand (medium cohesiveness) & 160.0 & 169.5 & 9.5 \\
\hline & $\begin{array}{l}\text { Light gray, very fine-grained clayey sand (moderately cohesive, sand/clay con- } \\
\text { tact at } 173 \text { feet) }\end{array}$ & 169.5 & 173.0 & 3.5 \\
\hline & $\begin{array}{l}\text { Medium reddish-brown and light gray, yellow-brown, and dark brown mottled } \\
\text { silty clay (dry, brittle with slickensides) }\end{array}$ & 173.0 & 177.0 & 4.0 \\
\hline & Reddish-brown clay & 177.0 & 178.5 & 1.5 \\
\hline & Silty clay & 178.5 & 180.0 & 1.5 \\
\hline & Reds, yellows and orange horizontally mottled in silty sandy clay & 180.0 & 182.0 & 2.0 \\
\hline
\end{tabular}

Appendix 1. Lithologic descriptions.-Continued

Site name: SAS-101 (described by C. Dieter)

Altitude: 14.9 feet Total depth: 191 feet

Latitude / Longitude: $38^{\circ} 51^{\prime} 55.99^{\prime \prime} \mathrm{N} / 76^{\circ} 59^{\prime} 36.20^{\prime \prime} \mathrm{W}$

Core used in sections C-C' and D-D'

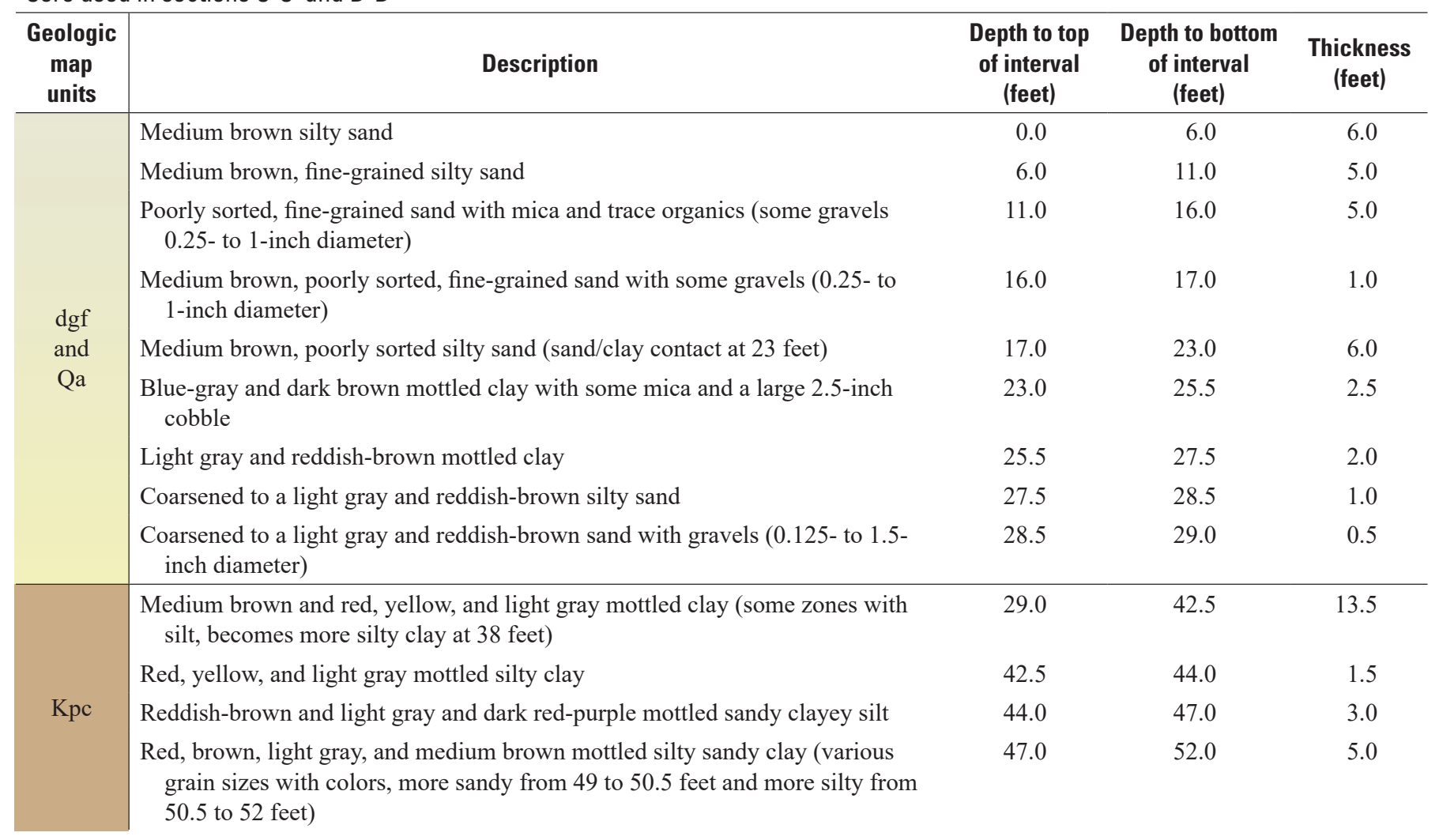


Appendix 1. Lithologic descriptions.-Continued

Site name: SAS-101 (described by C. Dieter)

Altitude: 14.9 feet Total depth: 191 feet

Latitude / Longitude: $38^{\circ} 51^{\prime} 55.99^{\prime \prime} \mathrm{N} / 76^{\circ} 59^{\prime} 36.20^{\prime \prime} \mathrm{W}$

Core used in sections $C-C^{\prime}$ and $D-D^{\prime}$

\begin{tabular}{|c|c|c|c|c|}
\hline $\begin{array}{c}\text { Geologic } \\
\text { map } \\
\text { units }\end{array}$ & Description & $\begin{array}{l}\text { Depth to top } \\
\text { of interval } \\
\text { (feet) }\end{array}$ & $\begin{array}{c}\text { Depth to bottom } \\
\text { of interval } \\
\text { (feet) }\end{array}$ & $\begin{array}{l}\text { Thickness } \\
\text { (feet) }\end{array}$ \\
\hline \multirow{16}{*}{$\mathrm{Kpc}$} & Transition to medium to light purple clayey silt & 52.0 & 53.5 & 1.5 \\
\hline & Light gray silty clay & 53.5 & 55.0 & 1.5 \\
\hline & Brownish-gray mottled clay & 55.0 & 57.0 & 2.0 \\
\hline & Medium brown and light gray and red purple mottled silty clay & 57.0 & 59.5 & 2.5 \\
\hline & Medium gray and purple mottled silty clay & 69.5 & 76.0 & 6.5 \\
\hline & Pink and light gray mottled clay & 76.0 & 77.5 & 1.5 \\
\hline & Light gray and pinkish-red mottled clay with trace of silt & 77.5 & 80.0 & 2.5 \\
\hline & Light gray silt mottled with pinkish-red clay & 94.5 & 96.0 & 1.5 \\
\hline & Reddish clayey silt with some light gray mottling & 96.0 & 98.0 & 2.0 \\
\hline & Red and light gray mottled silty clay & 98.0 & 100.0 & 2.0 \\
\hline & Dark purple-red clay with trace of silt & 100.0 & 102.5 & 2.5 \\
\hline & Light gray clayey silt mottled with red clay & 102.5 & 103.0 & 0.5 \\
\hline & Reddish-brown mottled silty clay & 103.0 & 107.0 & 4.0 \\
\hline & Red and light gray mottled clay & 107.0 & 109.0 & 2.0 \\
\hline & Red clay (less mottling than above) & 109.0 & 110.0 & 1.0 \\
\hline & Red and light gray mottled silty clay & 110.0 & 116.0 & 6.0 \\
\hline \multirow{7}{*}{ Kps } & Medium brown, cohesive, very fine-grained sand & 142.0 & 147.5 & 5.5 \\
\hline & $\begin{array}{l}\text { Medium- to coarse-grained sand (not cohesive until } 149.5 \text { feet, slightly cohesive } \\
\text { after that point) }\end{array}$ & 147.5 & 150.0 & 2.5 \\
\hline & Light brown-gray, fine-grained sand (some zones more cohesive than others) & 150.0 & 160.0 & 10.0 \\
\hline & Fine-grained, clayey (cohesive) sand & 160.0 & 168.0 & 8.0 \\
\hline & Medium-grained sand (not as cohesive as above) & 168.0 & 172.0 & 4.0 \\
\hline & Cohesive, medium-grained sand with lignite & 172.0 & 179.0 & 7.0 \\
\hline & Slightly cohesive, medium- to coarse-grained sand (no lignite after 180 feet, and & 179.0 & 184.0 & 5.0 \\
\hline
\end{tabular}
coarse-grained sand after 183 feet) 
Appendix 1. Lithologic descriptions.-Continued

Site name: SAS-101 (described by C. Dieter)

Altitude: 14.9 feet Total depth: 191 feet

Latitude / Longitude: $38^{\circ} 51^{\prime} 55.99^{\prime \prime} \mathrm{N} / 76^{\circ} 59^{\prime} 36.20^{\prime \prime} \mathrm{W}$

Core used in sections $C^{-}-C^{\prime}$ and $D-D^{\prime}$

\begin{tabular}{l|lccc}
\hline $\begin{array}{c}\text { Geologic } \\
\text { map } \\
\text { units }\end{array}$ & \multicolumn{1}{|c}{ Description } & $\begin{array}{c}\text { Depth to top } \\
\text { of interval } \\
\text { (feet) }\end{array}$ & $\begin{array}{c}\text { Depth to bottom } \\
\text { of interval } \\
\text { (feet) }\end{array}$ & $\begin{array}{c}\text { Thickness } \\
\text { (feet) }\end{array}$ \\
\hline & $\begin{array}{l}\text { Medium gray, poorly sorted clay with sand, pebbles, angular clay clasts and } \\
\text { mica (lignite at 185 feet) }\end{array}$ & 184.0 & 185.5 & 1.5 \\
& $\begin{array}{l}\text { Silt with pebbles } \\
\text { Kps }\end{array}$ & 185.5 & 187.0 & 1.5 \\
& $\begin{array}{l}\text { Cohesive, medium-grained sand with interbedded silty and sandy zones } \\
\text { Silty clay with interbedded silty and sandy zones }\end{array}$ & 187.0 & 188.0 & 1.0 \\
& Silty sand with interbedded silty and sandy zones & 188.0 & 189.0 & 1.0 \\
\hline
\end{tabular}

Appendix 1. Lithologic descriptions.-Continued

Site name: SAS-102 (described by C. Dieter)

Altitude: 12 feet Total depth: 195 feet

Latitude / Longitude: $38^{\circ} 51^{\prime} 51.81^{\prime \prime} \mathrm{N} / 77^{\circ} 00^{\prime} 03.53^{\prime \prime} \mathrm{W}$

Core used in sections $\mathrm{C}^{-\mathrm{C}^{\prime}}$ and $\mathrm{D}-\mathrm{D}^{\prime}$

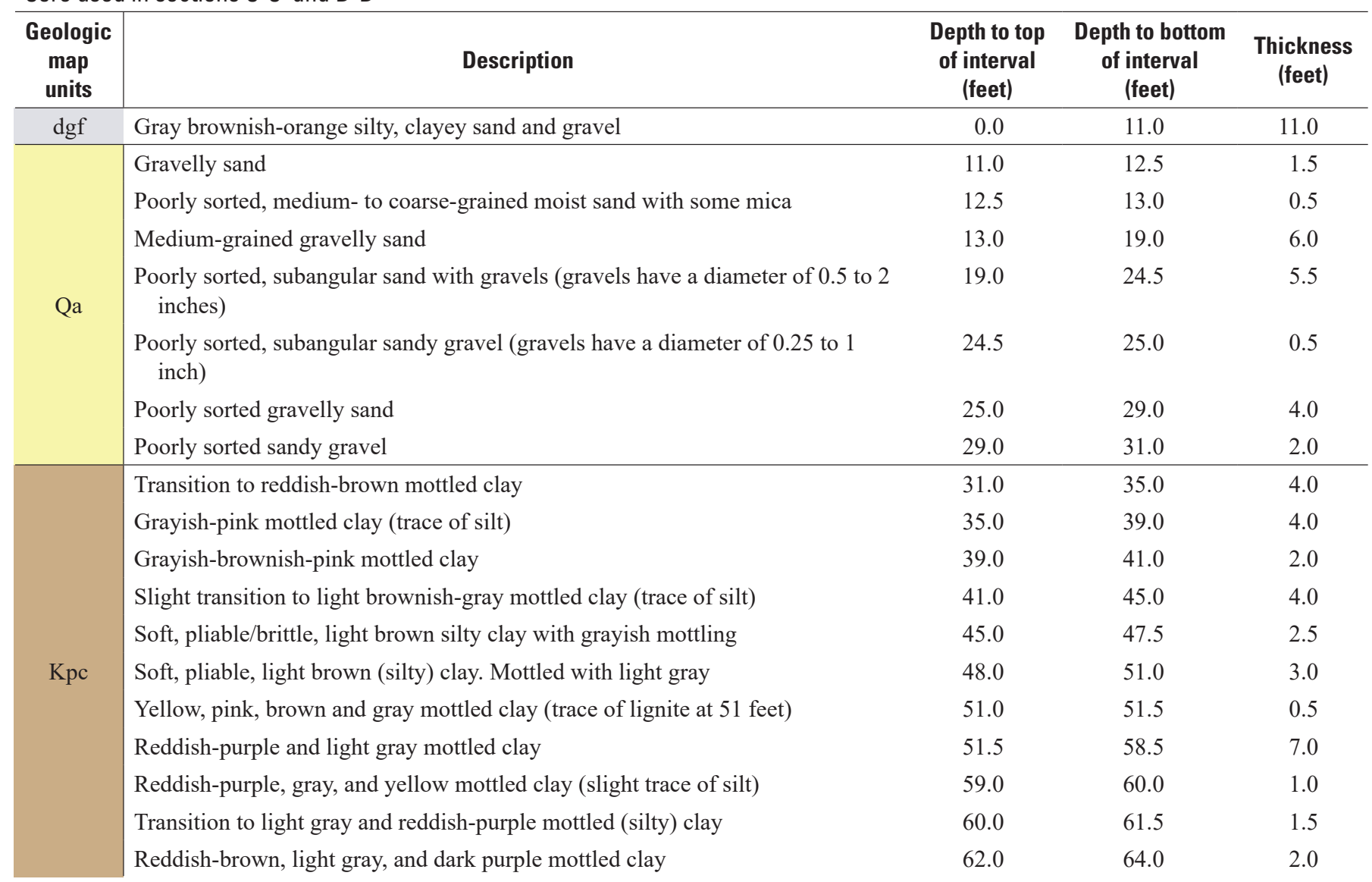


Appendix 1. Lithologic descriptions.-Continued

Site name: SAS-102 (described by C. Dieter)

Altitude: 12 feet Total depth: 195 feet

Latitude / Longitude: $38^{\circ} 51^{\prime} 51.81^{\prime \prime} \mathrm{N} / 77^{\circ} 00^{\prime} 03.53^{\prime \prime} \mathrm{W}$

Core used in sections $C-C^{\prime}$ and $D-D^{\prime}$

\begin{tabular}{|c|c|c|c|c|}
\hline $\begin{array}{c}\text { Geologic } \\
\text { map } \\
\text { units }\end{array}$ & Description & $\begin{array}{l}\text { Depth to top } \\
\text { of interval } \\
\text { (feet) }\end{array}$ & $\begin{array}{c}\text { Depth to bottom } \\
\text { of interval } \\
\text { (feet) }\end{array}$ & $\begin{array}{l}\text { Thickness } \\
\text { (feet) }\end{array}$ \\
\hline \multirow{8}{*}{ Kрс } & Transition to reddish-purple brown silty sandy mottled clay & 64.0 & 65.0 & 1.0 \\
\hline & Hard, dry mottled silt & 65.0 & 68.0 & 3.0 \\
\hline & Reddish-brown micaceous silt (trace clay) & 68.0 & 71.0 & 3.0 \\
\hline & Transition to clayey silt & 71.0 & 75.0 & 4.0 \\
\hline & Light gray and reddish-purple mottled (sandy) silt (very fine-grained sand) & 79.5 & 81.0 & 1.5 \\
\hline & Red clay with slickensides & 81.0 & 85.5 & 4.5 \\
\hline & Red silty clay & 85.5 & 89.0 & 3.5 \\
\hline & Soft red clay & 89.0 & 91.5 & 2.5 \\
\hline \multirow{17}{*}{ Kps } & Reddish-brown silty sand & 106.0 & 115.0 & 9.0 \\
\hline & Silty sand & 115.0 & 116.5 & 1.5 \\
\hline & Medium brown silty very fine-grained sand & 116.5 & 119.5 & 3.0 \\
\hline & Yellow-brown silty clay & 119.5 & 121.0 & 1.5 \\
\hline & Transition to medium brown-gray silty sand & 121.0 & 122.0 & 1.0 \\
\hline & Medium brown clayey sandy silt (slightly mottled with light gray) & 122.0 & 125.0 & 3.0 \\
\hline & Light gray, cohesive, fine-grained clayey sand (less cohesive at $134-135$ feet) & 125.5 & 136.0 & 10.5 \\
\hline & $\begin{array}{l}\text { Light gray, subrounded, poorly sorted, cohesive/clayey, fine- to medium-grained } \\
\text { sand }\end{array}$ & 136.0 & 137.5 & 1.5 \\
\hline & Moderately well-sorted medium-grained sand with traces of silt & 150.0 & 151.0 & 1.0 \\
\hline & Sandy silt & 151.0 & 152.5 & 1.5 \\
\hline & Dark to medium gray sandy silt with lignite & 152.5 & 154.0 & 1.5 \\
\hline & Dark to medium gray, fine-grained sand with some lignite & 154.0 & 156.5 & 2.5 \\
\hline & $\begin{array}{l}\text { Dark to medium gray, fine-grained sand with some lignite (some areas have } \\
\text { clays and silts) }\end{array}$ & 156.5 & 160.0 & 3.5 \\
\hline & Light gray, well-sorted, fine-grained sand with traces of silt, clay, and mica & 160.0 & 161.5 & 1.5 \\
\hline & Dark gray silty clay (hard, dry,brittle) & 161.5 & 164.0 & 2.5 \\
\hline & Very fine-grained sand & 164.0 & 164.5 & 0.5 \\
\hline & Dark gray silty clay (hard, dry, brittle) & 164.5 & 166.0 & 1.5 \\
\hline
\end{tabular}


Appendix 1. Lithologic descriptions.-Continued

Site name: SAS-102 (described by C. Dieter)

Altitude: 12 feet Total depth: 195 feet

Latitude / Longitude: $38^{\circ} 51^{\prime} 51.81^{\prime \prime} \mathrm{N} / 77^{\circ} 00^{\prime} 03.53^{\prime \prime} \mathrm{W}$

Core used in sections $C^{-}-C^{\prime}$ and $D-D^{\prime}$

\begin{tabular}{|c|c|c|c|c|}
\hline $\begin{array}{l}\text { Geologic } \\
\text { map } \\
\text { units }\end{array}$ & Description & $\begin{array}{l}\text { Depth to top } \\
\text { of interval } \\
\text { (feet) }\end{array}$ & $\begin{array}{l}\text { Depth to bottom } \\
\text { of interval } \\
\text { (feet) }\end{array}$ & $\begin{array}{c}\text { Thickness } \\
\text { (feet) }\end{array}$ \\
\hline \multirow{12}{*}{ Kps } & Very fine-grained silty sand with some lignite & 166.0 & 166.5 & 0.5 \\
\hline & Silty clay & 166.5 & 168.5 & 2.0 \\
\hline & Transition to light gray, poorly sorted, medium-grained sand & 168.5 & 172.0 & 3.5 \\
\hline & Poorly sorted, coarse-grained clayey sand with lignite & 172.0 & 173.5 & 1.5 \\
\hline & Yellow, brown, gray poorly sorted silty, clayey fine-grained sand & 173.5 & 175.0 & 1.5 \\
\hline & Very fine-grained sandy silt & 175.0 & 175.5 & 0.5 \\
\hline & Grading into silty sand & 175.5 & 176.0 & 0.5 \\
\hline & Light yellow-gray, very fine-grained silty sand & 176.0 & 183.0 & 7.0 \\
\hline & Dark gray silty clay with some slickensides & 183.0 & 185.0 & 2.0 \\
\hline & Medium gray silty clayey sand (coarsening downwards) & 185.0 & 188.0 & 3.0 \\
\hline & Light gray, slightly cohesive, fine- to medium- grained sand & 188.0 & 191.5 & 3.5 \\
\hline & Fine-grained, cohesive sandy clay & 191.5 & 195.0 & 3.5 \\
\hline
\end{tabular}

Appendix 1. Lithologic descriptions.-Continued

Site name: SAS-103 (described by C. Dieter)

Altitude: 10 feet Total depth: 152.5 feet

Latitude / Longitude: $38^{\circ} 52^{\prime} 28.78^{\prime \prime} \mathrm{N} / 77^{\circ} 00^{\prime} 13.38^{\prime \prime} \mathrm{W}$

Core used in section $\mathrm{C}^{-\mathrm{C}^{\prime}}$

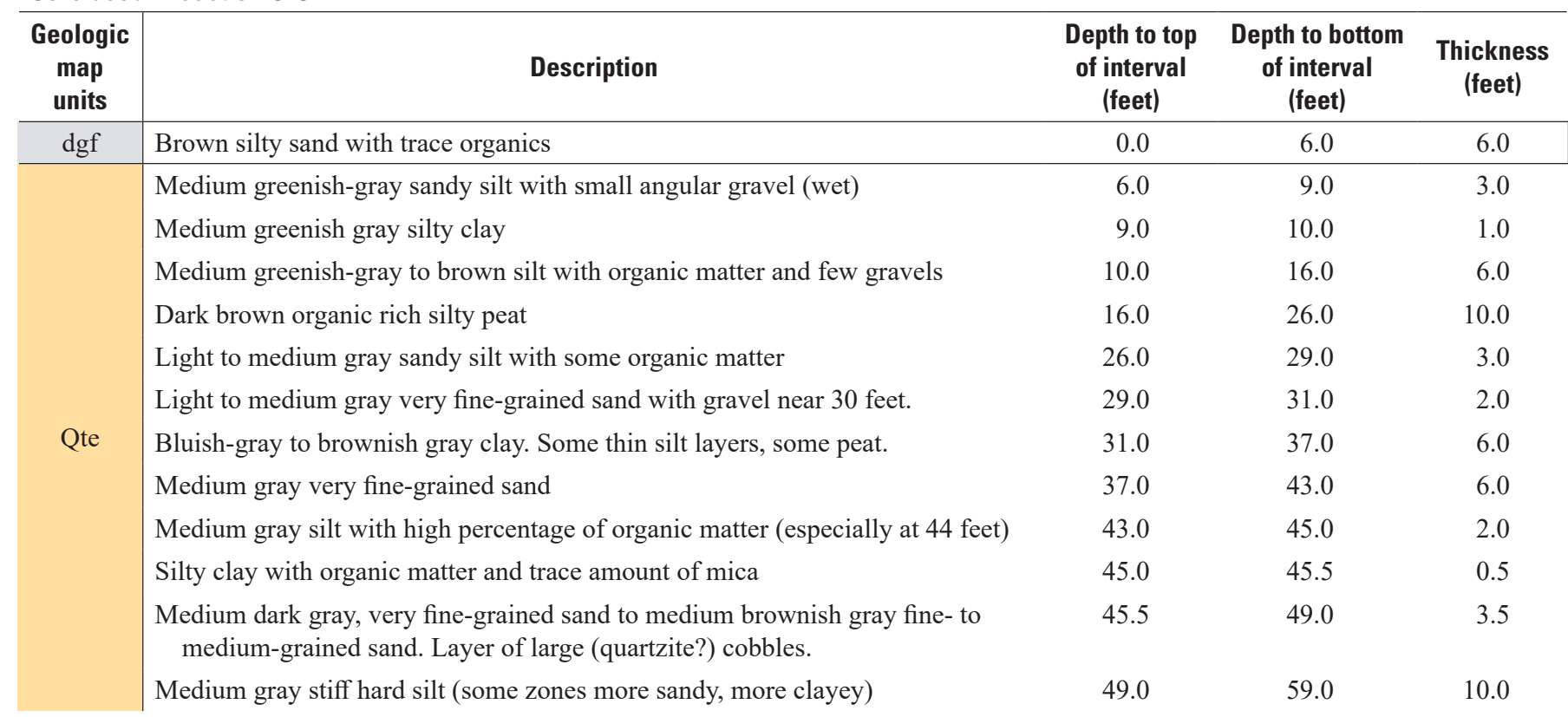


Appendix 1. Lithologic descriptions.-Continued

Site name: SAS-103 (described by C. Dieter)

Altitude: 10 feet Total depth: 152.5 feet

Latitude / Longitude: $38^{\circ} 52^{\prime} 28.78^{\prime \prime} \mathrm{N} / 77^{\circ} 00^{\prime} 13.38^{\prime \prime} \mathrm{W}$

Core used in section C-C'

\begin{tabular}{|c|c|c|c|c|}
\hline $\begin{array}{c}\text { Geologic } \\
\text { map } \\
\text { units }\end{array}$ & Description & $\begin{array}{l}\text { Depth to top } \\
\text { of interval } \\
\text { (feet) }\end{array}$ & $\begin{array}{c}\text { Depth to bottom } \\
\text { of interval } \\
\text { (feet) }\end{array}$ & $\begin{array}{l}\text { Thickness } \\
\text { (feet) }\end{array}$ \\
\hline \multirow{5}{*}{ Qte } & Medium brownish-gray fine-grained sand & 59.0 & 62.5 & 3.5 \\
\hline & Light to medium gray sandy clayey silt & 62.5 & 65.0 & 2.5 \\
\hline & $\begin{array}{l}\text { Light gray fine to medium-grained clayey sand with 1-2-inch long pieces of } \\
\text { lignite/organic matter }\end{array}$ & 65.0 & 66.0 & 1.0 \\
\hline & $\begin{array}{l}\text { Medium to dark gray silt with high percentage of organic matter and woody } \\
\text { pieces }\end{array}$ & 71.0 & 76.0 & 5.0 \\
\hline & Light gray medium-grained clayey sand with organic matter & 76.0 & 79.0 & 3.0 \\
\hline \multirow{8}{*}{ Kps } & $\begin{array}{l}\text { Bluish-green medium gray silty clay (hard, dry, brittle) with pockets of medium- } \\
\text { to coarse-grained sand }\end{array}$ & 79.0 & 83.0 & 4.0 \\
\hline & Medium bluish-gray clayey silt & 111.0 & 112.0 & 1.0 \\
\hline & Poorly sorted, angular, clayey, coarse-grained sand & 112.0 & 116.0 & 4.0 \\
\hline & Poorly sorted, very fine-grained silty sand with some organic matter & 116.0 & 118.0 & 2.0 \\
\hline & Dark grayish-brown, clayey silt with trace mica & 118.0 & 120.0 & 2.0 \\
\hline & Dark gray sandy silt with zones of high percentage of organic matter and lignite & 120.0 & 127.0 & 7.0 \\
\hline & $\begin{array}{l}\text { Dark gray silty clay with high percentage of organic matter and lignite. Some } \\
\text { zones with more clay or very fine-grained sand. }\end{array}$ & 127.0 & 134.0 & 7.0 \\
\hline & $\begin{array}{l}\text { Fine-grained silty sand, poorly sorted with 6-inch thick layer of high organic } \\
\text { content. }\end{array}$ & 134.0 & 136.0 & 2.0 \\
\hline
\end{tabular}


Appendix 1. Lithologic descriptions.-Continued

Site name: SAS-104 (described by C. Dieter)

Altitude: 6.3 feet Total depth: 175 feet

Latitude / Longitude: $38^{\circ} 52^{\prime} 40.83^{\prime \prime} \mathrm{N} / 76^{\circ} 58^{\prime} 42.99^{\prime \prime} \mathrm{W}$

Not used in cross sections

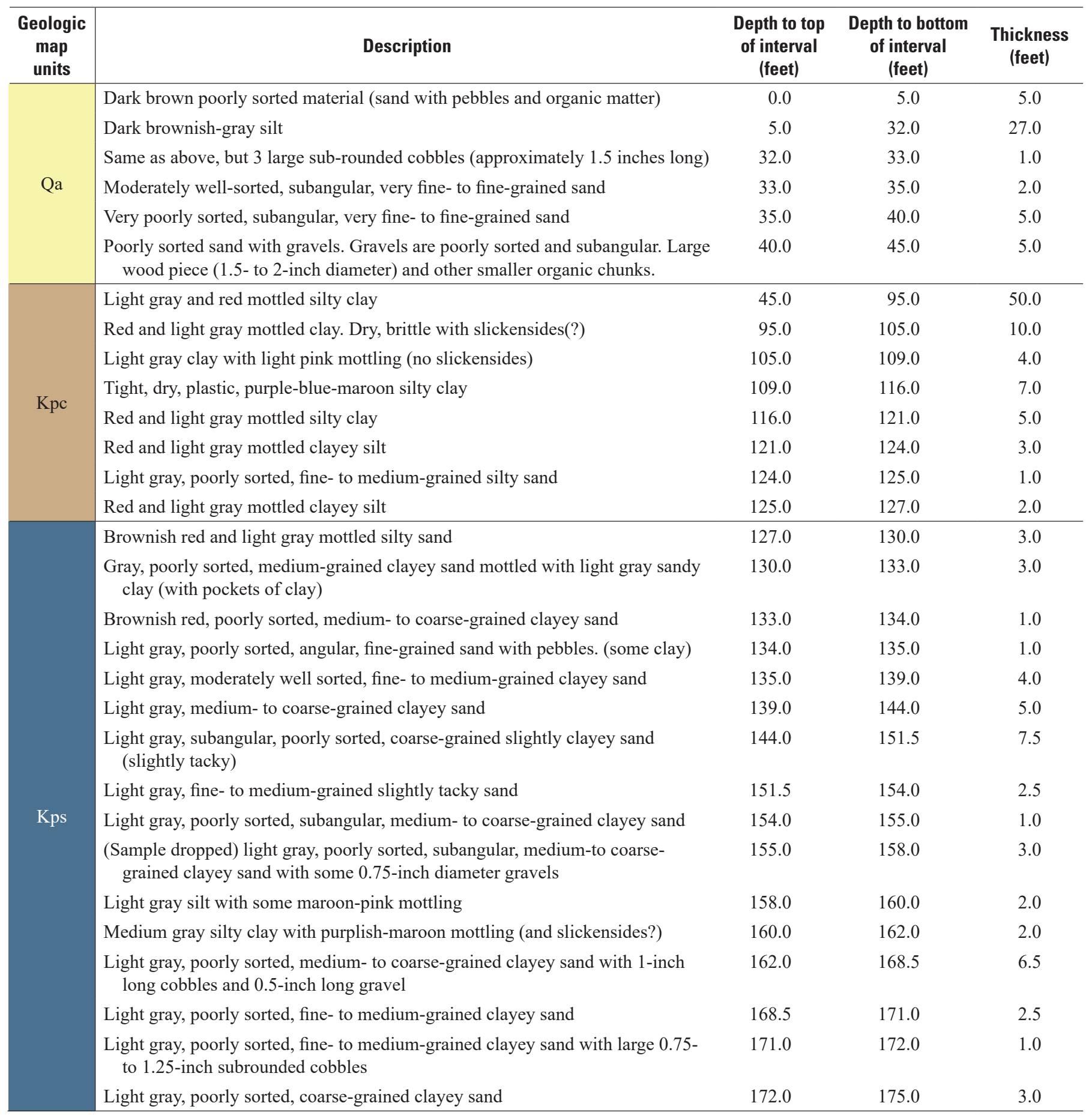


Appendix 1. Lithologic descriptions.-Continued

Site name: SAS-106 (described by C. Dieter)

Altitude: 13 feet Total depth: 166 feet

Latitude / Longitude: $38^{\circ} 53^{\prime} 46.70^{\prime \prime} \mathrm{N} / 76^{\circ} 58^{\prime} 06.63^{\prime \prime} \mathrm{W}$

Core used in section D-D'

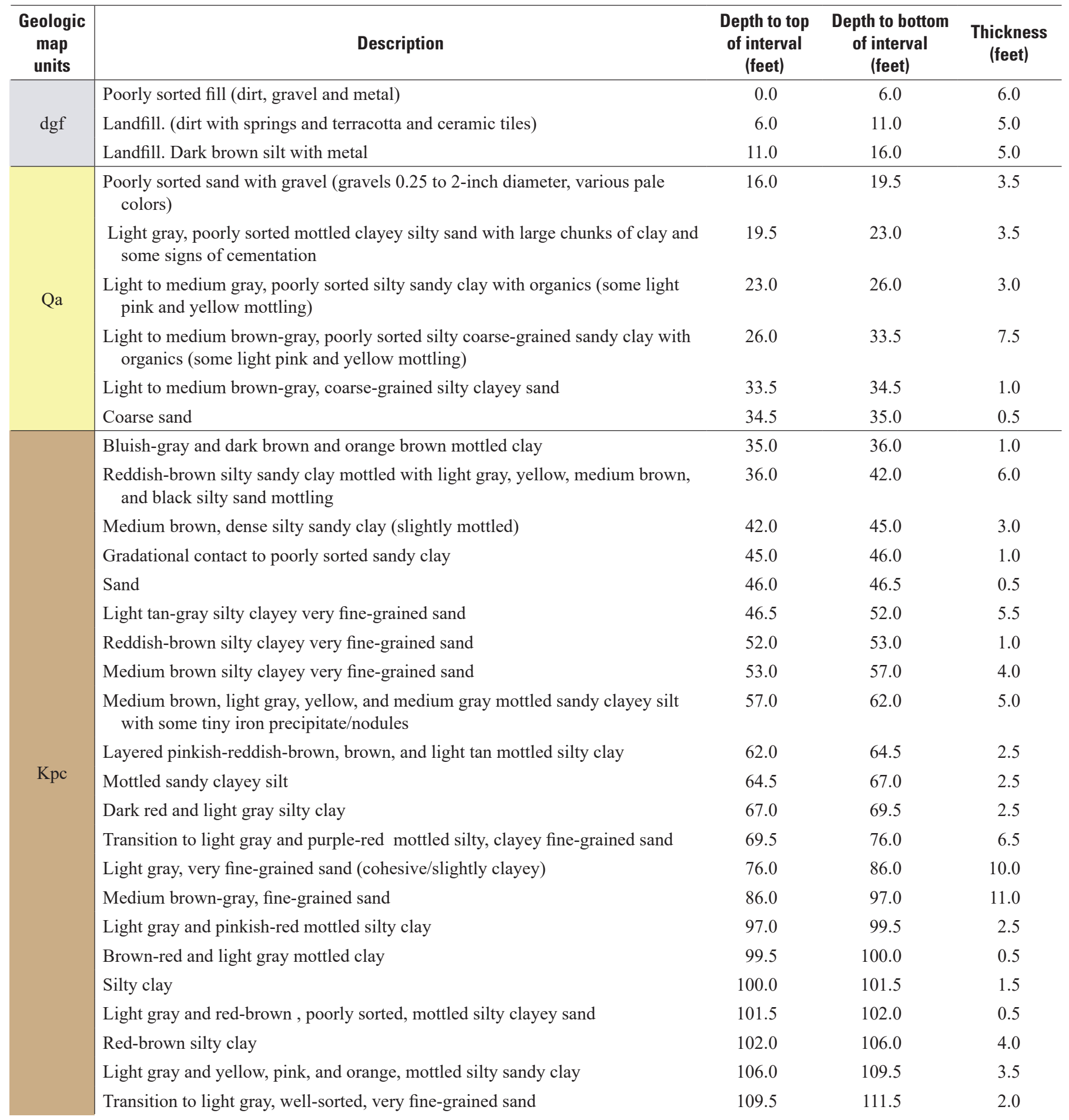


Appendix 1. Lithologic descriptions.-Continued

Site name: SAS-106 (described by C. Dieter)

Altitude: 13 feet Total depth: 166 feet

Latitude / Longitude: $38^{\circ} 53^{\prime} 46.70^{\prime \prime} \mathrm{N} / 76^{\circ} 58^{\prime} 06.63^{\prime \prime} \mathrm{W}$

Core used in section D-D'

\begin{tabular}{|c|c|c|c|c|}
\hline $\begin{array}{l}\text { Geologic } \\
\text { map } \\
\text { units }\end{array}$ & Description & $\begin{array}{l}\text { Depth to top } \\
\text { of interval } \\
\text { (feet) }\end{array}$ & $\begin{array}{l}\text { Depth to bottom } \\
\text { of interval } \\
\text { (feet) }\end{array}$ & $\begin{array}{c}\text { Thickness } \\
\text { (feet) }\end{array}$ \\
\hline \multirow{9}{*}{ Kpc } & $\begin{array}{l}\text { Poorly sorted, fine- to medium-grained sand (somewhat cohesive with light } \\
\text { colored grains and dark minerals) }\end{array}$ & 111.5 & 113.0 & 1.5 \\
\hline & $\begin{array}{l}\text { Light bluish-gray, fine-grained,very cohesive clayey sand with some pink lay- } \\
\text { ered mottling and blue clay clasts }\end{array}$ & 113.0 & 117.5 & 4.5 \\
\hline & Dark purple silty clay & 117.5 & 120.5 & 3.0 \\
\hline & Dark purple clay & 120.5 & 121.0 & 0.5 \\
\hline & Light gray, coarse-grained sand with some clay & 121.0 & 123.0 & 2.0 \\
\hline & Coarse sand interbedded with gray purple-red clay & 123.0 & 124.0 & 1.0 \\
\hline & Dark purple clay & 124.0 & 125.0 & 1.0 \\
\hline & Coarse sand interbedded with gray purple-red clay & 125.0 & 125.5 & 0.5 \\
\hline & Light gray silty sandy clay with some pink mottling & 125.5 & 126.0 & 0.5 \\
\hline \multirow{3}{*}{ Kps } & $\begin{array}{l}\text { Light gray, fine- to medium-grained sand with multicolored grains (white, clear, } \\
\text { tan, pink, mica, black, yellow, and orange) }\end{array}$ & 126.0 & 146.5 & 20.5 \\
\hline & Dark gray sandy clayey silt (high organic content) & 146.5 & 149.0 & 2.5 \\
\hline & $\begin{array}{l}\text { Medium gray, fine-grained clayey silty sand with clasts of silver mica in hard } \\
\text { cemented rock and organic matter/lignite (more clayey then sandy and more } \\
\text { organic matter from } 164 \text { to } 166 \text { feet) }\end{array}$ & 149.0 & 166.0 & 17.0 \\
\hline
\end{tabular}

Appendix 1. Lithologic descriptions.-Continued

Site name: SAS-107 (described by C. Dieter)

Altitude: 30.4 feet Total depth: 166 feet

Latitude / Longitude: $38^{\circ} 53^{\prime} 59.57^{\prime \prime} \mathrm{N} / 76^{\circ} 58^{\prime} 09.18^{\prime \prime} \mathrm{W}$

Core used in section D-D'

\begin{tabular}{|c|c|c|c|c|}
\hline $\begin{array}{c}\text { Geologic } \\
\text { map } \\
\text { units }\end{array}$ & Description & $\begin{array}{l}\text { Depth to top } \\
\text { of interval } \\
\text { (feet) }\end{array}$ & $\begin{array}{l}\text { Depth to bottom } \\
\text { of interval } \\
\text { (feet) }\end{array}$ & $\begin{array}{l}\text { Thickness } \\
\text { (feet) }\end{array}$ \\
\hline $\operatorname{dgf}$ & $\begin{array}{l}\text { Poorly sorted, clayey landfill with glass and muck at } 1 \text { foot and large gravels and } \\
\text { chunks of brick at } 8 \text { feet }\end{array}$ & 0.0 & 12.5 & 12.5 \\
\hline Qa & Reddish-brown, poorly sorted silty clayey sand & 12.5 & 15.0 & 2.5 \\
\hline \multirow{5}{*}{$\mathrm{Kpc}$} & Light gray and orange-red brown mottled clay & 15.0 & 16.0 & 1.0 \\
\hline & Light gray and dark purple and yellow mottled clay & 19.0 & 22.0 & 3.0 \\
\hline & Light gray, orange and pink-red mottled clay (soft) & 22.0 & 29.5 & 7.5 \\
\hline & $\begin{array}{l}\text { Light to medium gray mottled clay, mottled with specks of dark gray, pink, and } \\
\text { yellow }\end{array}$ & 29.5 & 36.0 & 6.5 \\
\hline & Medium brown and pinkish-red and yellow mottled clay & 36.0 & 41.0 & 5.0 \\
\hline
\end{tabular}


Appendix 1. Lithologic descriptions.-Continued

Site name: SAS-107 (described by C. Dieter)

Altitude: 30.4 feet Total depth: 166 feet

Latitude / Longitude: $38^{\circ} 53^{\prime} 59.57^{\prime \prime} \mathrm{N} / 76^{\circ} 58^{\prime} 09.18^{\prime \prime} \mathrm{W}$

Core used in section D-D'

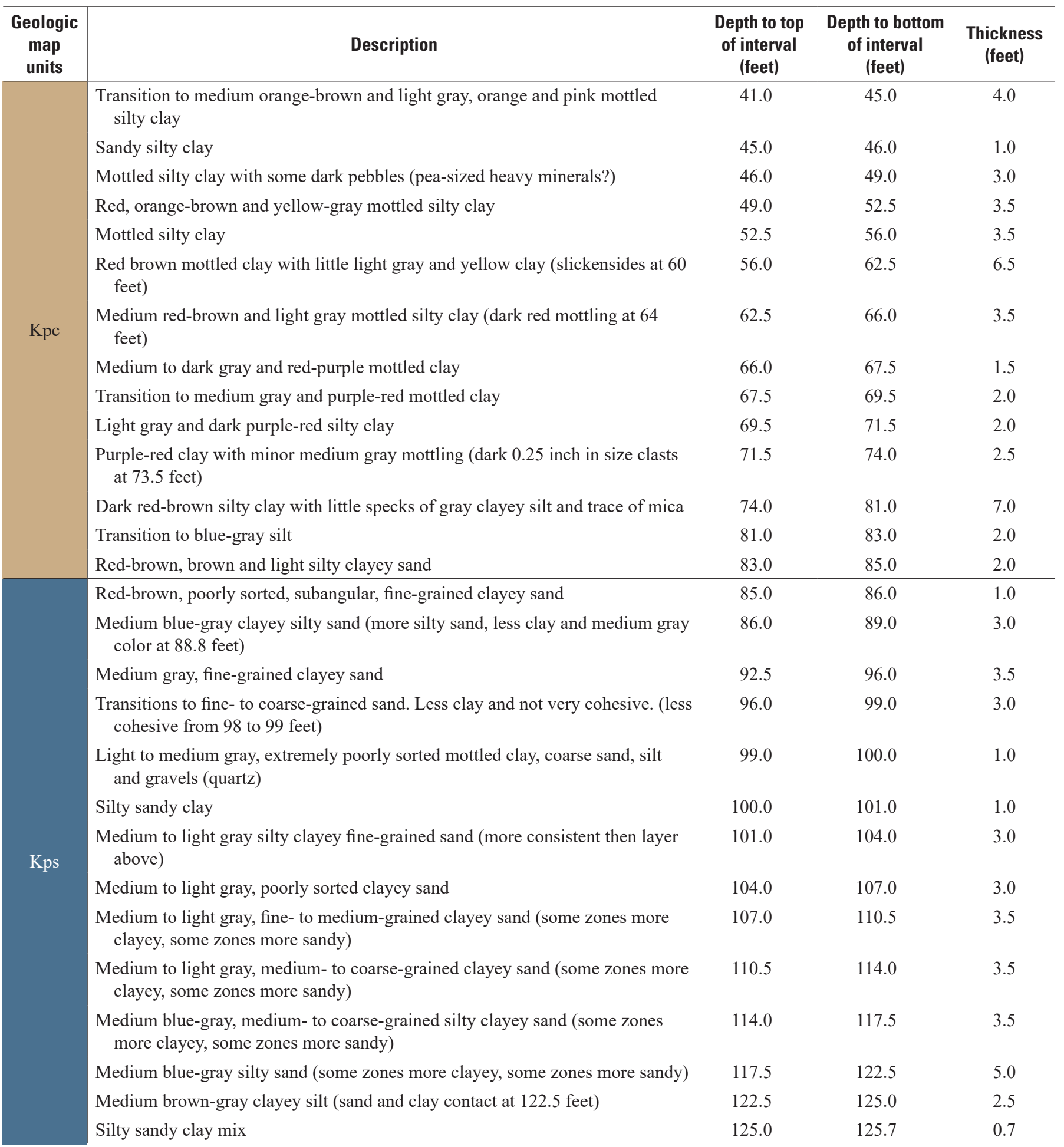


Appendix 1. Lithologic descriptions.-Continued

Site name: SAS-107 (described by C. Dieter)

Altitude: 30.4 feet Total depth: 166 feet

Latitude / Longitude: $38^{\circ} 53^{\prime} 59.57^{\prime \prime} \mathrm{N} / 76^{\circ} 58^{\prime} 09.18^{\prime \prime} \mathrm{W}$

Core used in section D-D'

\begin{tabular}{|c|c|c|c|c|}
\hline $\begin{array}{l}\text { Geologic } \\
\text { map } \\
\text { units }\end{array}$ & Description & $\begin{array}{l}\text { Depth to top } \\
\text { of interval } \\
\text { (feet) }\end{array}$ & $\begin{array}{l}\text { Depth to bottom } \\
\text { of interval } \\
\text { (feet) }\end{array}$ & $\begin{array}{c}\text { Thickness } \\
\text { (feet) }\end{array}$ \\
\hline \multirow{16}{*}{ Kps } & Poorly sorted, very fine- to medium-grained sand & 125.7 & 126.0 & 0.3 \\
\hline & Medium to light tan-gray, poorly sorted, medium-grained sand & 126.0 & 128.5 & 2.5 \\
\hline & Light blue-gray, poorly sorted, slightly cohesive sand & 128.5 & 129.0 & 0.5 \\
\hline & Light gray, poorly sorted, slightly cohesive medium-grained sand & 129.0 & 132.5 & 3.5 \\
\hline & Light blue-gray, slightly cohesive fine-grained sand & 132.5 & 135.5 & 3.0 \\
\hline & Light gray, poorly sorted, coarse-grained sand & 135.5 & 136.0 & 0.5 \\
\hline & Poorly sorted, interbedded clay and sand & 136.0 & 137.7 & 1.7 \\
\hline & Light gray, very fine-grained silty sand & 137.5 & 139.0 & 1.5 \\
\hline & Light gray, very fine-grained sandy silt & 139.0 & 142.5 & 3.5 \\
\hline & Light gray sandy clayey silt (some zones more silty, some more clayey) & 142.5 & 152.0 & 9.5 \\
\hline & Light gray silty sand & 152.0 & 152.5 & 0.5 \\
\hline & Medium gray sandy silt & 152.5 & 155.5 & 3.0 \\
\hline & Medium gray silty sand & 155.5 & 157.5 & 2.0 \\
\hline & Medium gray silt (lignite at 158 feet) & 157.5 & 159.0 & 1.5 \\
\hline & Gray, very fine-grained silty sand & 159.0 & 160.5 & 1.5 \\
\hline & Medium gray silty sand and sandy silt & 160.5 & 166.0 & 5.5 \\
\hline
\end{tabular}

Appendix 1. Lithologic descriptions.-Continued

Site name: SAS-108 (described by C. Dieter)

Altitude: 69.4 feet Total depth: 172 feet

Latitude / Longitude: $38^{\circ} 54^{\prime} 39.10^{\prime \prime} \mathrm{N} / 76^{\circ} 59^{\prime} 08.82^{\prime \prime} \mathrm{W}$

Not used in cross-sections

\begin{tabular}{c|lccc}
\hline $\begin{array}{c}\text { Geologic } \\
\text { map } \\
\text { units }\end{array}$ & \multicolumn{1}{|c}{ Description } & $\begin{array}{c}\text { Depth to top } \\
\text { of interval } \\
\text { (feet) }\end{array}$ & $\begin{array}{c}\text { Depth to bottom } \\
\text { of interval } \\
\text { (feet) }\end{array}$ & $\begin{array}{c}\text { Thickness } \\
\text { (feet) }\end{array}$ \\
\hline \multirow{3}{*}{ dgf } & No recovery & 0.0 & 2.0 & 2.0 \\
& Very fine-grained sand (slightly silty). & 2.0 & 3.5 & 1.5 \\
& Sand and gravels & 3.5 & 5.5 & 2.0 \\
\hline \multirow{3}{*}{ Kpc } & Light gray mottled (silty) clay. Some organic matter. & 5.5 & 13.0 & 7.5 \\
& Red, light gray, yellow-brown, mottled, silty clay with some organic matter & 13.0 & 19.0 & 6.0 \\
& Medium brown, soft, slightly mottled, clayey silt. & 19.0 & 24.0 & 5.0 \\
& Poorly sorted, clayey sand with large round 2-inch diameter cobble and $0.75-$ & 24.0 & 26.0 & 2.0 \\
& $\quad$ inch gravels. & & & 3.0 \\
& Brownish red and light gray mottled clayey silt. & 26.0 & 29.0 & 3.0 \\
& Brownish-red, mottled silty clay & 29.0 & 33.0 & 4.0 \\
& Mottled, layered, purplish red clay. (slickensides(?) at 33.5 feet) & 33.0 & 38.0 & 5.0 \\
& Red, light gray, yellow-brown, mottled silt & 38.0 & 40.0 & 2.0 \\
\hline
\end{tabular}


Appendix 1. Lithologic descriptions.-Continued

Site name: SAS-108 (described by C. Dieter)

Altitude: 69.4 feet Total depth: 172 feet

Latitude / Longitude: $38^{\circ} 54^{\prime} 39.10^{\prime \prime} \mathrm{N} / 76^{\circ} 59^{\prime} 08.82^{\prime \prime} \mathrm{W}$

Not used in cross-sections

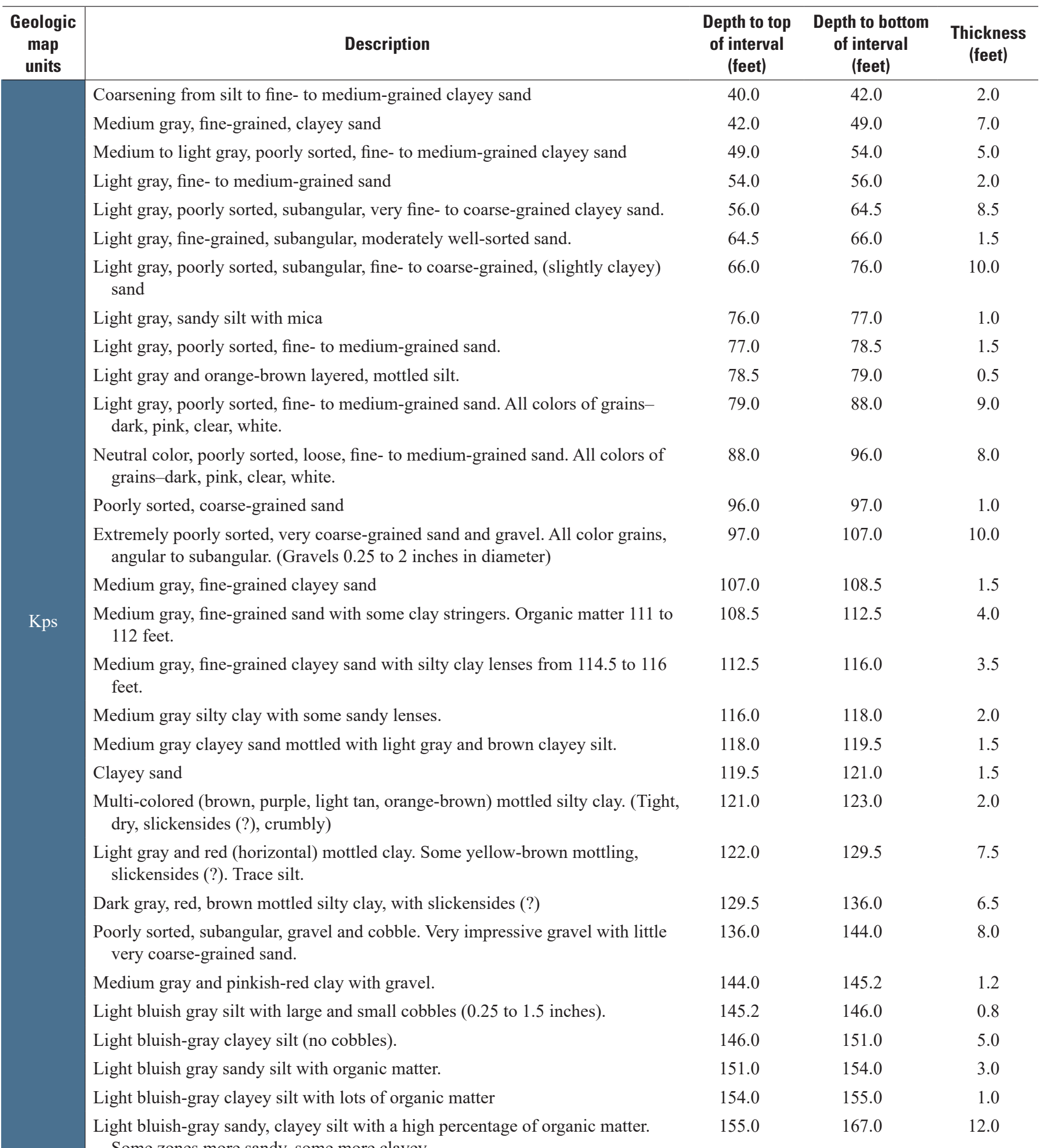
Some zones more sandy, some more clayey. 
Appendix 1. Lithologic descriptions.-Continued

Site name: SAS-108 (described by C. Dieter)

Altitude: 69.4 feet Total depth: 172 feet

Latitude / Longitude: $38^{\circ} 54^{\prime} 39.10^{\prime \prime} \mathrm{N} / 76^{\circ} 59^{\prime} 08.82^{\prime \prime} \mathrm{W}$

Not used in cross-sections

\begin{tabular}{|c|c|c|c|c|}
\hline $\begin{array}{c}\text { Geologic } \\
\text { map } \\
\text { units }\end{array}$ & Description & $\begin{array}{c}\text { Depth to top } \\
\text { of interval } \\
\text { (feet) }\end{array}$ & $\begin{array}{l}\text { Depth to bottom } \\
\text { of interval } \\
\text { (feet) }\end{array}$ & $\begin{array}{c}\text { Thickness } \\
\text { (feet) }\end{array}$ \\
\hline \multirow{3}{*}{ Kps } & Light bluish-gray, poorly sorted, angular, coarse-grained clayey sand. & 167.0 & 168.0 & 1.0 \\
\hline & 1.5-inch layer of cemented coarse-grained sand. & 168.0 & 168.2 & 0.2 \\
\hline & $\begin{array}{l}\text { Light bluish-gray, poorly sorted, angular, coarse-grained sand with organic mat- } \\
\text { ter. }\end{array}$ & 168.2 & 172.0 & 3.8 \\
\hline
\end{tabular}

Appendix 1. Lithologic descriptions.-Continued

Site name: SAS-109 (described by C. Dieter)

Altitude: 4 feet Total depth: 177 feet

Latitude / Longitude: $38^{\circ} 52^{\prime} 16.50^{\prime \prime} \mathrm{N} / 76^{\circ} 59^{\prime} 15.31^{\prime \prime} \mathrm{W}$

Core used in section D-D'

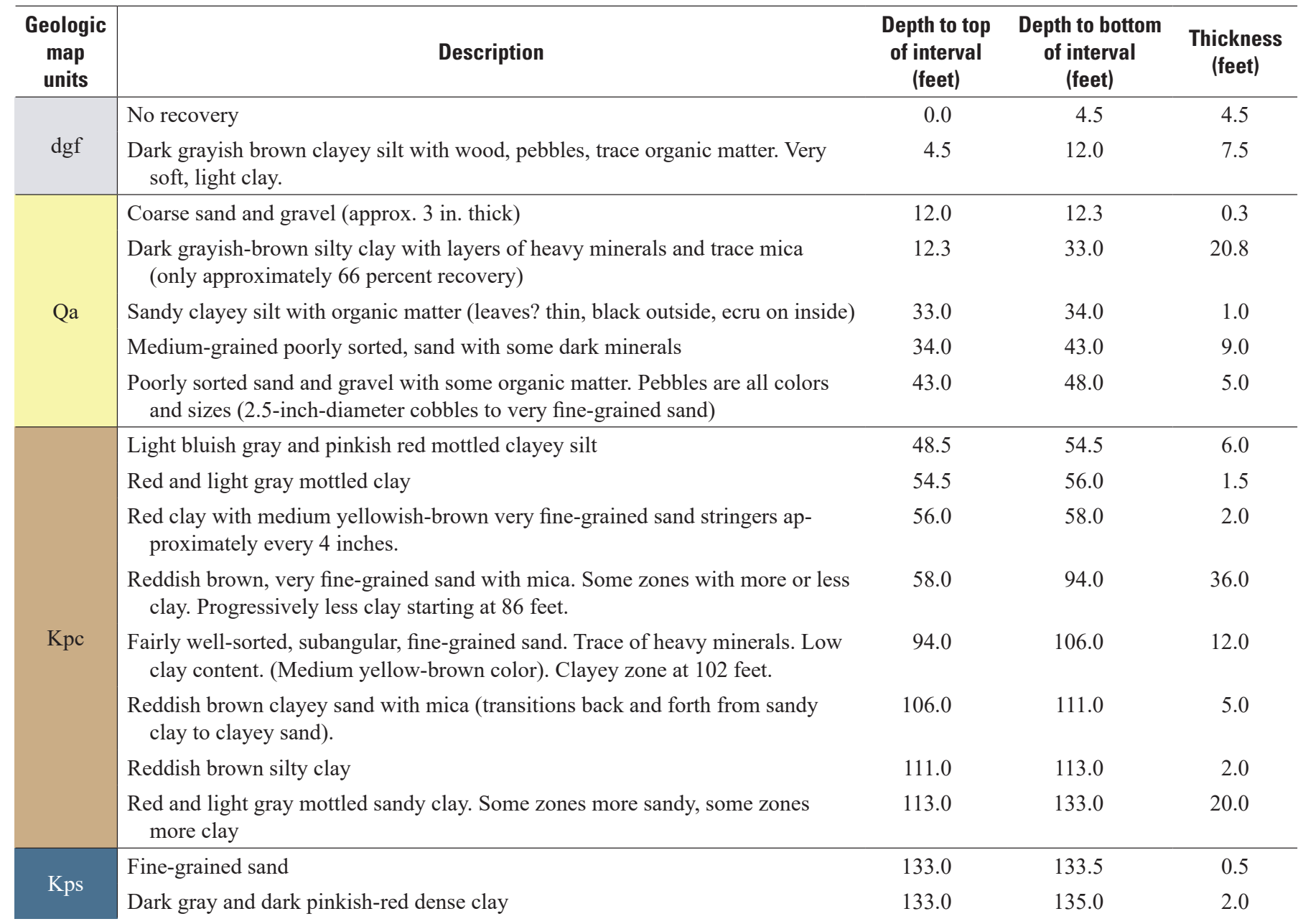


Appendix 1. Lithologic descriptions.-Continued

Site name: SAS-109 (described by C. Dieter)

Altitude: 4 feet Total depth: 177 feet

Latitude / Longitude: $38^{\circ} 52^{\prime} 16.50^{\prime \prime} \mathrm{N} / 76^{\circ} 59^{\prime} 15.31^{\prime \prime} \mathrm{W}$

Core used in section D-D'

\begin{tabular}{|c|c|c|c|c|}
\hline $\begin{array}{c}\text { Geologic } \\
\text { map } \\
\text { units }\end{array}$ & Description & $\begin{array}{c}\text { Depth to top } \\
\text { of interval } \\
\text { (feet) }\end{array}$ & $\begin{array}{l}\text { Depth to bottom } \\
\text { of interval } \\
\text { (feet) }\end{array}$ & $\begin{array}{l}\text { Thickness } \\
\text { (feet) }\end{array}$ \\
\hline \multirow{7}{*}{ Kps } & Poorly sorted, subangular, coarse-grained sand & 135.0 & 137.0 & 2.0 \\
\hline & Dark bluish-gray sandy silt & 137.0 & 138.5 & 1.5 \\
\hline & Very fine-grained sand & 138.5 & 140.0 & 1.5 \\
\hline & Medium bluish-gray sandy silt & 140.0 & 141.0 & 1.0 \\
\hline & Light gray sandy silt with mica and heavy minerals. Sand is very fine-grained & 147.0 & 154.0 & 7.0 \\
\hline & $\begin{array}{l}\text { Very fine- to coarse-grained, poorly sorted, subangular clayey sand. Clay/silt } \\
\text { content increases with depth. Coarse sand content decreases with depth }\end{array}$ & 153.0 & 162.0 & 9.0 \\
\hline & $\begin{array}{l}\text { Deep maroon and dark gray, very hard, dry, brittle clayey silt (with slicken- } \\
\text { sides?) }\end{array}$ & 162.0 & 167.0 & 5.0 \\
\hline
\end{tabular}

Appendix 1. Lithologic descriptions.-Continued

Site name: SAS-110 (described by C. Dieter)

Altitude: 7.2 feet Total depth: 177 feet

Latitude / Longitude: $38^{\circ} 52^{\prime} 31.87^{\prime \prime} \mathrm{N} / 76^{\circ} 58^{\prime} 37.78^{\prime \prime} \mathrm{W}$

Core used in section D-D'

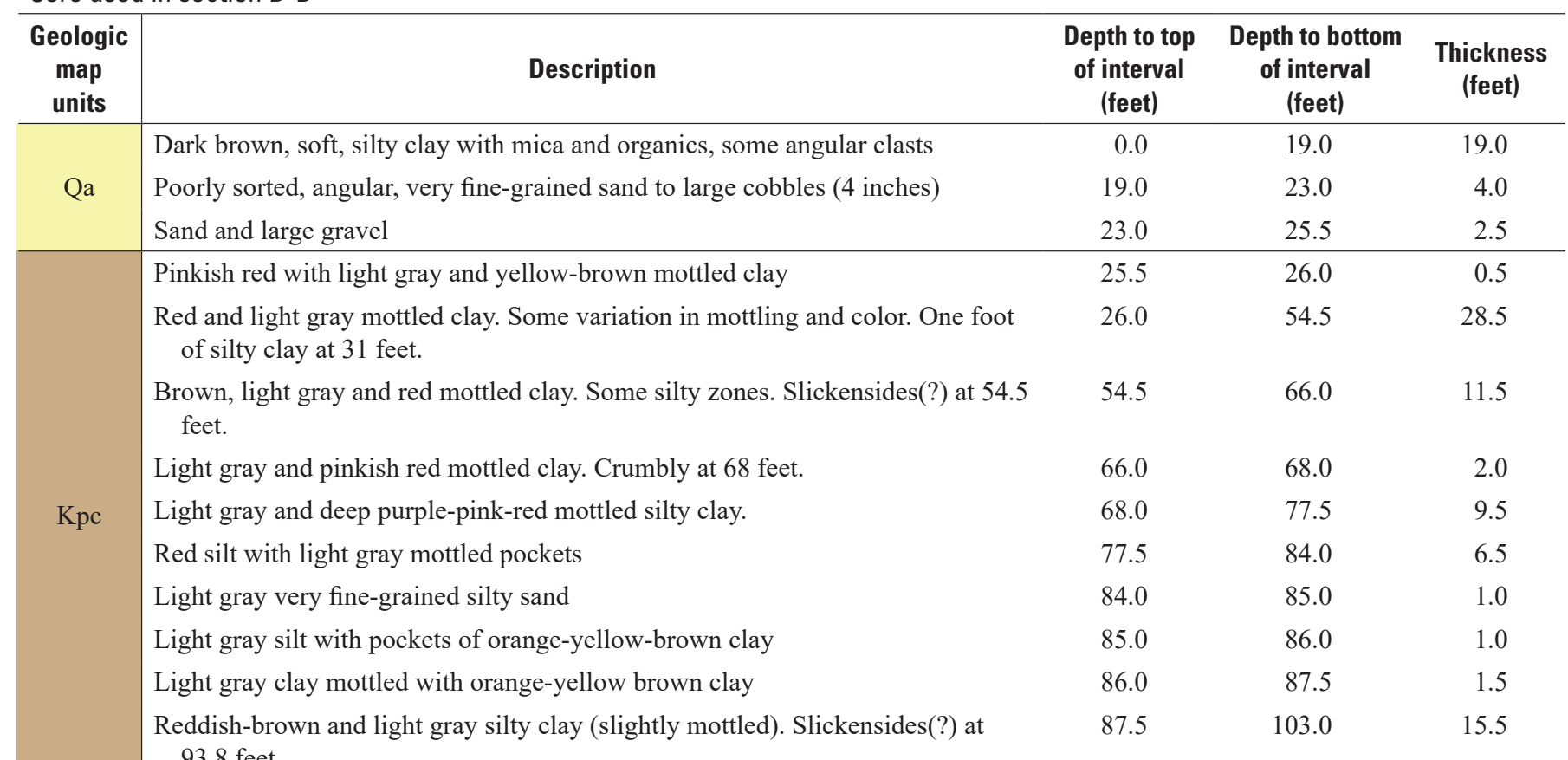


Appendix 1. Lithologic descriptions.-Continued

Site name: SAS-110 (described by C. Dieter)

Altitude: 7.2 feet Total depth: 177 feet

Latitude / Longitude: $38^{\circ} 52^{\prime} 31.87^{\prime \prime} \mathrm{N} / 76^{\circ} 58^{\prime} 37.78^{\prime \prime} \mathrm{W}$

Core used in section D-D'

\begin{tabular}{|c|c|c|c|c|}
\hline $\begin{array}{l}\text { Geologic } \\
\text { map } \\
\text { units }\end{array}$ & Description & $\begin{array}{l}\text { Depth to top } \\
\text { of interval } \\
\text { (feet) }\end{array}$ & $\begin{array}{l}\text { Depth to bottom } \\
\text { of interval } \\
\text { (feet) }\end{array}$ & $\begin{array}{c}\text { Thickness } \\
\text { (feet) }\end{array}$ \\
\hline \multirow{9}{*}{$\mathrm{Kpc}$} & Maroon-red and light gray mottled clay. Slickensides near 104 feet. & 103.0 & 114.0 & 11.0 \\
\hline & Red clay with pockets of light gray silt & 114.0 & 116.0 & 2.0 \\
\hline & $\begin{array}{l}\text { Reddish-brown, light gray and yellow-brown mottled clay. Crumbly zone with } \\
\text { slickensides(?) at } 118 \text { feet }\end{array}$ & 116.0 & 119.0 & 3.0 \\
\hline & Multi-colored mottled clay with some silt & 119.0 & 128.0 & 9.0 \\
\hline & Multi-colored mottled clayey silt & 128.0 & 129.0 & 1.0 \\
\hline & Coarse-grained sand & 129.0 & 130.0 & 1.0 \\
\hline & Medium to light gray tight clay & 130.0 & 131.0 & 1.0 \\
\hline & Multi-colored brownish-red silty clay with slickensides(?) & 131.0 & 133.0 & 2.0 \\
\hline & Purplish-red and light gray mottled clayey silt & 133.0 & 143.0 & 10.0 \\
\hline \multirow{9}{*}{ Kps } & Light gray and purplish-red, mottled, silty, very fine-grained sand & 143.0 & 146.0 & 3.0 \\
\hline & Light gray, very fine-grained silty, clayey, sand & 146.0 & 147.5 & 1.5 \\
\hline & Light gray, fine-grained clayey sand & 147.5 & 149.0 & 1.5 \\
\hline & Light gray, poorly sorted, subangular clayey sand & 149.0 & 151.5 & 2.5 \\
\hline & Very poorly sorted very fine-grained sand to small pebbles & 151.5 & 151.8 & 0.3 \\
\hline & $\begin{array}{l}\text { Mottled light and medium gray and pinkish gray coarse-grained sand with clay } \\
\text { pockets }\end{array}$ & 151.8 & 156.0 & 4.2 \\
\hline & Light gray, medium gray, and purple gray silty sandy clay & 156.0 & 159.0 & 3.0 \\
\hline & Med gray and purple gray clay (with slickensides (?)) & 159.0 & 161.0 & 2.0 \\
\hline & $\begin{array}{l}\text { Light gray, poorly sorted, subangular, medium- to coarse-grained clayey sand. } \\
\text { (Some clay clasts at } 176.5 \text { to } 177 \text { feet) }\end{array}$ & 161.0 & 177.0 & 16.0 \\
\hline
\end{tabular}

Appendix 1. Lithologic descriptions.-Continued

Site name: SAS-111 (described by C. Dieter)

Altitude: 13 feet Total depth: 185 feet

Latitude / Longitude: $38^{\circ} 52^{\prime} 49.82^{\prime \prime} \mathrm{N} / 76^{\circ} 58^{\prime} 08.50^{\prime \prime} \mathrm{W}$

Core used in section D-D'

\begin{tabular}{|c|c|c|c|c|}
\hline $\begin{array}{c}\text { Geologic } \\
\text { map } \\
\text { units }\end{array}$ & Description & $\begin{array}{l}\text { Depth to top } \\
\text { of interval } \\
\text { (feet) }\end{array}$ & $\begin{array}{l}\text { Depth to bottom } \\
\text { of interval } \\
\text { (feet) }\end{array}$ & $\begin{array}{l}\text { Thickness } \\
\text { (feet) }\end{array}$ \\
\hline \multirow{2}{*}{ dgf } & No recovery & 0.0 & 8.0 & 8.0 \\
\hline & Gravel and dirt fill & 8.0 & 11.0 & 3.0 \\
\hline \multirow{3}{*}{ Qa } & $\begin{array}{l}\text { Dark brown, soft silt with mica and organic matter. Sandy at } 12 \text { feet with small } \\
\text { shells }\end{array}$ & 11.0 & 15.0 & 4.0 \\
\hline & Very fine-grained, moderately well-sorted sand & 28.0 & 29.0 & 1.0 \\
\hline & High organic-rich silt & 29.0 & 29.5 & 0.5 \\
\hline
\end{tabular}


Appendix 1. Lithologic descriptions.-Continued

Site name: SAS-111 (described by C. Dieter)

Altitude: 13 feet Total depth: 185 feet

Latitude / Longitude: $38^{\circ} 52^{\prime} 49.82^{\prime \prime} \mathrm{N} / 76^{\circ} 58^{\prime} 08.50^{\prime \prime} \mathrm{W}$

Core used in section D-D'

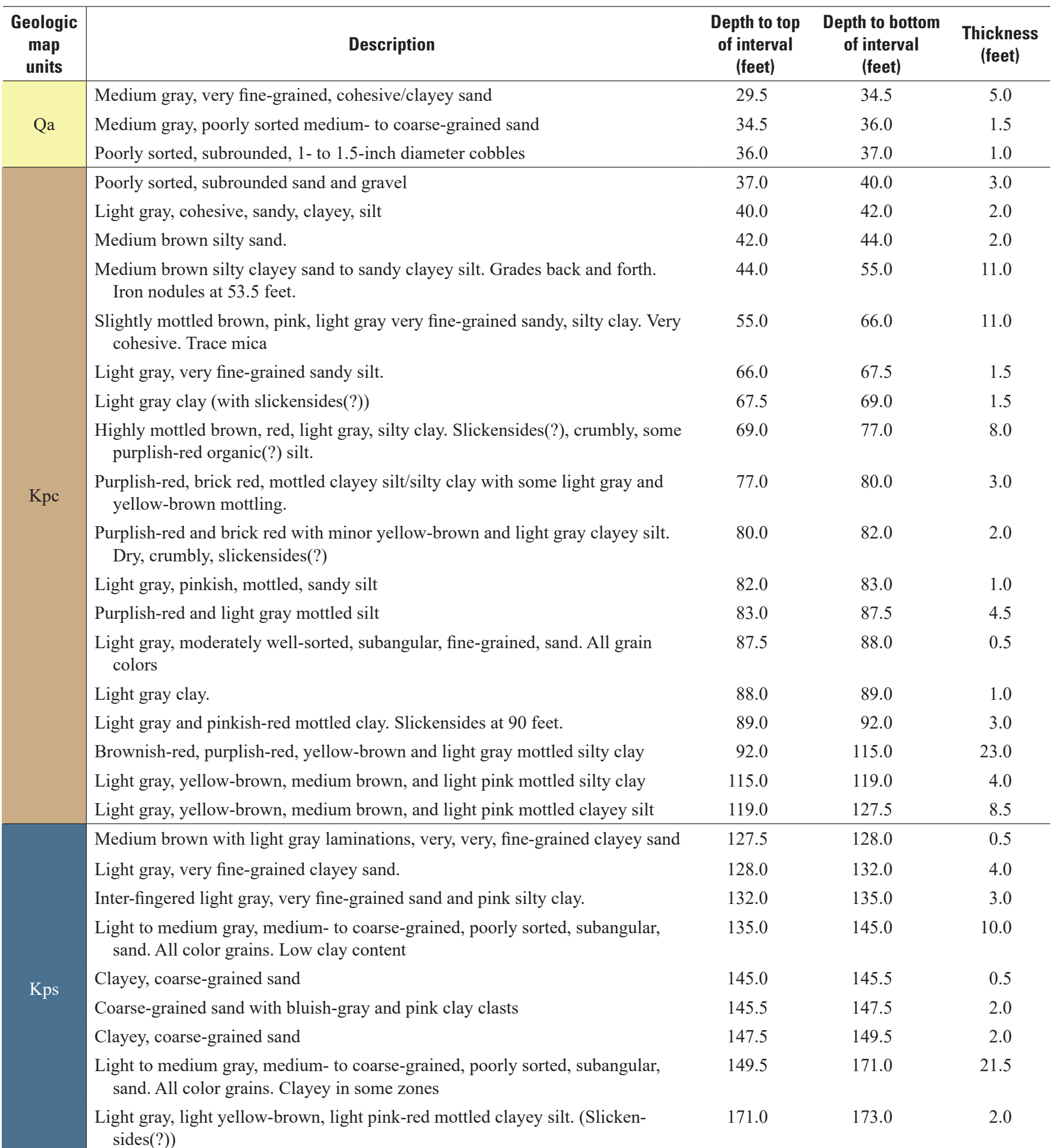


Appendix 1. Lithologic descriptions.-Continued

Site name: SAS-111 (described by C. Dieter)

Altitude: 13 feet Total depth: 185 feet

Latitude / Longitude: $38^{\circ} 52^{\prime} 49.82^{\prime \prime} \mathrm{N} / 76^{\circ} 58^{\prime} 08.50^{\prime \prime} \mathrm{W}$

Core used in section D-D'

\begin{tabular}{|c|c|c|c|c|}
\hline $\begin{array}{l}\text { Geologic } \\
\text { map } \\
\text { units }\end{array}$ & Description & $\begin{array}{l}\text { Depth to top } \\
\text { of interval } \\
\text { (feet) }\end{array}$ & $\begin{array}{l}\text { Depth to bottom } \\
\text { of interval } \\
\text { (feet) }\end{array}$ & $\begin{array}{l}\text { Thickness } \\
\text { (feet) }\end{array}$ \\
\hline \multirow{3}{*}{ Kps } & Red with light gray mottled silt. & 173.0 & 173.5 & 0.5 \\
\hline & $\begin{array}{l}\text { Medium brown, red-brown, yellow-brown layered, mottled silt. Hard and dry in } \\
\text { some zones. Sand and clay pockets }\end{array}$ & 173.5 & 182.0 & 8.5 \\
\hline & $\begin{array}{l}\text { Medium to light gray, poorly sorted, subangular, medium- to coarse-grained } \\
\text { clayey sand. Multi-colored grains. }\end{array}$ & 182.0 & 185.0 & 3.0 \\
\hline
\end{tabular}

Appendix 1. Lithologic descriptions.-Continued

Site name: SAS-112 (described by C. Dieter)

Altitude: 10.3 feet Total depth: 175 feet

Latitude / Longitude: $38^{\circ} 53^{\prime} 15.36^{\prime \prime} \mathrm{N} / 76^{\circ} 58^{\prime} 11.37^{\prime \prime} \mathrm{W}$

Core used in section D-D'

\begin{tabular}{|c|c|c|c|c|}
\hline $\begin{array}{c}\text { Geologic } \\
\text { map } \\
\text { units }\end{array}$ & Description & $\begin{array}{l}\text { Depth to top } \\
\text { of interval } \\
\text { (feet) }\end{array}$ & $\begin{array}{l}\text { Depth to bottom } \\
\text { of interval } \\
\text { (feet) }\end{array}$ & $\begin{array}{l}\text { Thickness } \\
\text { (feet) }\end{array}$ \\
\hline \multirow{6}{*}{$\operatorname{dgf}$} & Medium gray-brown, poorly sorted, gravelly sandy mud (brick chunk at 6 feet) & 0.0 & 8.0 & 8.0 \\
\hline & Light tan, poorly sorted, muddy fill with gravels & 8.0 & 10.0 & 2.0 \\
\hline & Burnt land fill (black, hard, tar-like) & 10.0 & 15.0 & 5.0 \\
\hline & Dark brown mud with metal chunks and wire & 15.0 & 18.0 & 3.0 \\
\hline & Dark gray-brown silty mud (low density) & 21.5 & 30.0 & 8.5 \\
\hline & Dark gray-brown sandy mud & 30.0 & 33.0 & 3.0 \\
\hline \multirow{3}{*}{ Qa } & $\begin{array}{l}\text { Medium gray-brown to tan silt coarsening downward to very fine-grained sand } \\
\text { by } 34.5 \text { feet }\end{array}$ & 33.0 & 35.0 & 2.0 \\
\hline & $\begin{array}{l}\text { Tan fine-grained sand with a pebble coarsening to medium-grained sand by } 37 \\
\text { feet }\end{array}$ & 35.0 & 37.0 & 2.0 \\
\hline & $\begin{array}{l}\text { Very poorly sorted, very mixed sand with gravels (gravels are } 0.25 \text { to } 2 \text { inches in } \\
\text { diameter) }\end{array}$ & 39.0 & 40.0 & 1.0 \\
\hline \multirow{5}{*}{ Kpc } & $\begin{array}{l}\text { Transition to light gray, orange, red, dark brown, some pink and some purple, } \\
\text { silty mottled clay }\end{array}$ & 40.0 & 41.5 & 1.5 \\
\hline & Reddish-brown and yellow-tan mottled clay with a trace of dark red silt & 41.5 & 45.0 & 3.5 \\
\hline & $\begin{array}{l}\text { Reddish-brown, purple and light gray mottled silty clay with trace of sand (be- } \\
\text { comes progressively more sandy and silty) }\end{array}$ & 45.0 & 48.5 & 3.5 \\
\hline & $\begin{array}{l}\text { Dark purple-red, very fine-grained sandy clayey silt with little light gray, pink } \\
\text { and red mottling }\end{array}$ & 48.5 & 51.0 & 2.5 \\
\hline & Transition to dark brownish-red (silty) clay (mottled to slightly mottled) & 51.0 & 55.0 & 4.0 \\
\hline
\end{tabular}


Appendix 1. Lithologic descriptions.-Continued

Site name: SAS-112 (described by C. Dieter)

Altitude: 10.3 feet Total depth: 175 feet

Latitude / Longitude: $38^{\circ} 53^{\prime} 15.36^{\prime \prime} \mathrm{N} / 76^{\circ} 58^{\prime} 11.37^{\prime \prime} \mathrm{W}$

Core used in section D-D'

\begin{tabular}{|c|c|c|c|c|}
\hline $\begin{array}{l}\text { Geologic } \\
\text { map } \\
\text { units }\end{array}$ & Description & $\begin{array}{l}\text { Depth to top } \\
\text { of interval } \\
\text { (feet) }\end{array}$ & $\begin{array}{l}\text { Depth to bottom } \\
\text { of interval } \\
\text { (feet) }\end{array}$ & $\begin{array}{l}\text { Thickness } \\
\text { (feet) }\end{array}$ \\
\hline \multirow{19}{*}{ Kрс } & $\begin{array}{l}\text { Dark brownish-red slightly mottled clayey silt/silty clay (some very fine-grained } \\
\text { light gray sand mottling, decreasing at } 58 \text { feet) }\end{array}$ & 55.0 & 64.5 & 9.5 \\
\hline & Transitions to more silty clay then clayey silt & 64.5 & 66.0 & 1.5 \\
\hline & Medium brown, dark red, and pink-orange mottled silty clay & 66.0 & 69.0 & 3.0 \\
\hline & Medium brown, dark red, and pink-orange mottled silty clay & 69.0 & 72.0 & 3.0 \\
\hline & Medium brown, dark red, and pink-orange mottled silty clay & 72.0 & 75.0 & 3.0 \\
\hline & $\begin{array}{l}\text { Brick red clay with thin light gray and orange mottling and a trace of silt (hard, } \\
\text { dense) (at } 86 \text { feet, mottled with } 4 \text { inches of light gray clayey very fine-grained } \\
\text { sand) }\end{array}$ & 75.0 & 88.0 & 13.0 \\
\hline & Pinkish-red and light gray mottled silty clay & 88.0 & 89.0 & 1.0 \\
\hline & Pinkish-red, hard, dense clay (slightly mottled, trace of silt) & 89.0 & 95.0 & 6.0 \\
\hline & Dark purple-red silty clay & 95.0 & 98.5 & 3.5 \\
\hline & Light bluish-gray, orange and red mottled clayey silt & 98.5 & 100.0 & 1.5 \\
\hline & $\begin{array}{l}\text { Speckled light bluish/greenish clayey silt with black, light to medium gray, } \\
\text { orange and yellow mottling }\end{array}$ & 100.0 & 101.5 & 1.5 \\
\hline & Brown, red-brown and brown-gray mottled clayey silt & 101.5 & 106.0 & 4.5 \\
\hline & Dark red-brown and pinkish-red mottled clayey sandy silt & 106.0 & 107.0 & 1.0 \\
\hline & Dark gray and pinkish-red clay & 107.0 & 108.0 & 1.0 \\
\hline & Dark gray clayey silt & 108.0 & 112.0 & 4.0 \\
\hline & Dark gray clayey silt (mottled with some light gray, very fine-grained sand) & 112.0 & 114.0 & 2.0 \\
\hline & Dark gray sandy clayey silt (at 120.5 feet becomes less sandy) & 114.0 & 122.0 & 8.0 \\
\hline & $\begin{array}{l}\text { Dark gray silty clay (more sandy silty clay at } 124 \text { feet and back to silty clay at } \\
125 \text { feet) }\end{array}$ & 122.0 & 125.0 & 3.0 \\
\hline & Dark gray sandy clayey silt & 125.0 & 129.0 & 4.0 \\
\hline \multirow{11}{*}{ Kps } & $\begin{array}{l}\text { Medium to light gray, poorly sorted, subangular to subrounded, medium- to } \\
\text { coarse-grained sand (more fine-grained sand at } 135 \text { feet with more cohesion/ } \\
\text { clay, returns to medium- to coarse-grained at } 138 \text { feet) }\end{array}$ & 129.0 & 143.5 & 14.5 \\
\hline & Grades into fine-grained clayey sand & 143.5 & 145.0 & 1.5 \\
\hline & Light to medium gray mottled silty clay/clayey silt & 145.0 & 147.0 & 2.0 \\
\hline & $\begin{array}{l}\text { Dark purple-gray and medium gray mottle silt (dry, changes to sandy silt at } 148 \\
\text { feet) }\end{array}$ & 147.0 & 148.5 & 1.5 \\
\hline & Dark purple-red silty clay (with slickensides) & 148.5 & 151.0 & 2.5 \\
\hline & Light gray sandy silt mottled with purple-red clayey silt & 151.0 & 152.5 & 1.5 \\
\hline & Transitions to clayey silty mottled sand & 152.5 & 153.5 & 1.0 \\
\hline & Light tan, poorly sorted, clayey (cohesive) sand & 153.5 & 155.0 & 1.5 \\
\hline & Back to light to medium gray, orange and brown, mottled silty sand & 155.0 & 156.5 & 1.5 \\
\hline & $\begin{array}{l}\text { Light and dark gray clay mottled with red, yellow, and brown silty clay/clayey } \\
\text { silt (slickensides at } 158.5 \text { feet) }\end{array}$ & 156.5 & 161.0 & 4.5 \\
\hline & Dark gray silty clay mottled with light gray and organic/dark matter & 161.0 & 162.0 & 1.0 \\
\hline
\end{tabular}


Appendix 1. Lithologic descriptions.-Continued

Site name: SAS-112 (described by C. Dieter)

Altitude: 10.3 feet Total depth: 175 feet

Latitude / Longitude: $38^{\circ} 53^{\prime} 15.36^{\prime \prime} \mathrm{N} / 76^{\circ} 58^{\prime} 11.37^{\prime \prime} \mathrm{W}$

Core used in section D-D'

\begin{tabular}{c|lccc}
\hline $\begin{array}{c}\text { Geologic } \\
\text { map } \\
\text { units }\end{array}$ & \multicolumn{1}{|c}{ Description } & $\begin{array}{c}\text { Depth to top } \\
\text { of interval } \\
\text { (feet) }\end{array}$ & $\begin{array}{c}\text { Depth to bottom } \\
\text { of interval } \\
\text { (feet) }\end{array}$ & $\begin{array}{c}\text { Thickness } \\
\text { (feet) }\end{array}$ \\
\hline \multirow{3}{*}{ Kps } & Dark gray silt (coarsening down to 165 feet) & 162.0 & 163.0 & 1.0 \\
& Medium gray sandy silt & 163.0 & 164.5 & 1.5 \\
& Light tan to white, very fine-grained silty sand & 164.5 & 165.5 & 1.0 \\
& Light tan-brown mottled clayey sandy silt & 165.5 & 169.0 & 3.5 \\
& Light gray, moderately well-sorted, very fine-grained sand & 169.0 & 175.0 & 6.0 \\
\hline
\end{tabular}

Appendix 1. Lithologic descriptions.-Continued

Site name: SAS-201 (described by C. Dieter)

Altitude: 20.2 feet Total depth: 216 feet

Latitude / Longitude: $38^{\circ} 49^{\prime} 07.93^{\prime \prime} \mathrm{N} / 77^{\circ} 01^{\prime} 05.78^{\prime \prime} \mathrm{W}$

Core used in section D-D'

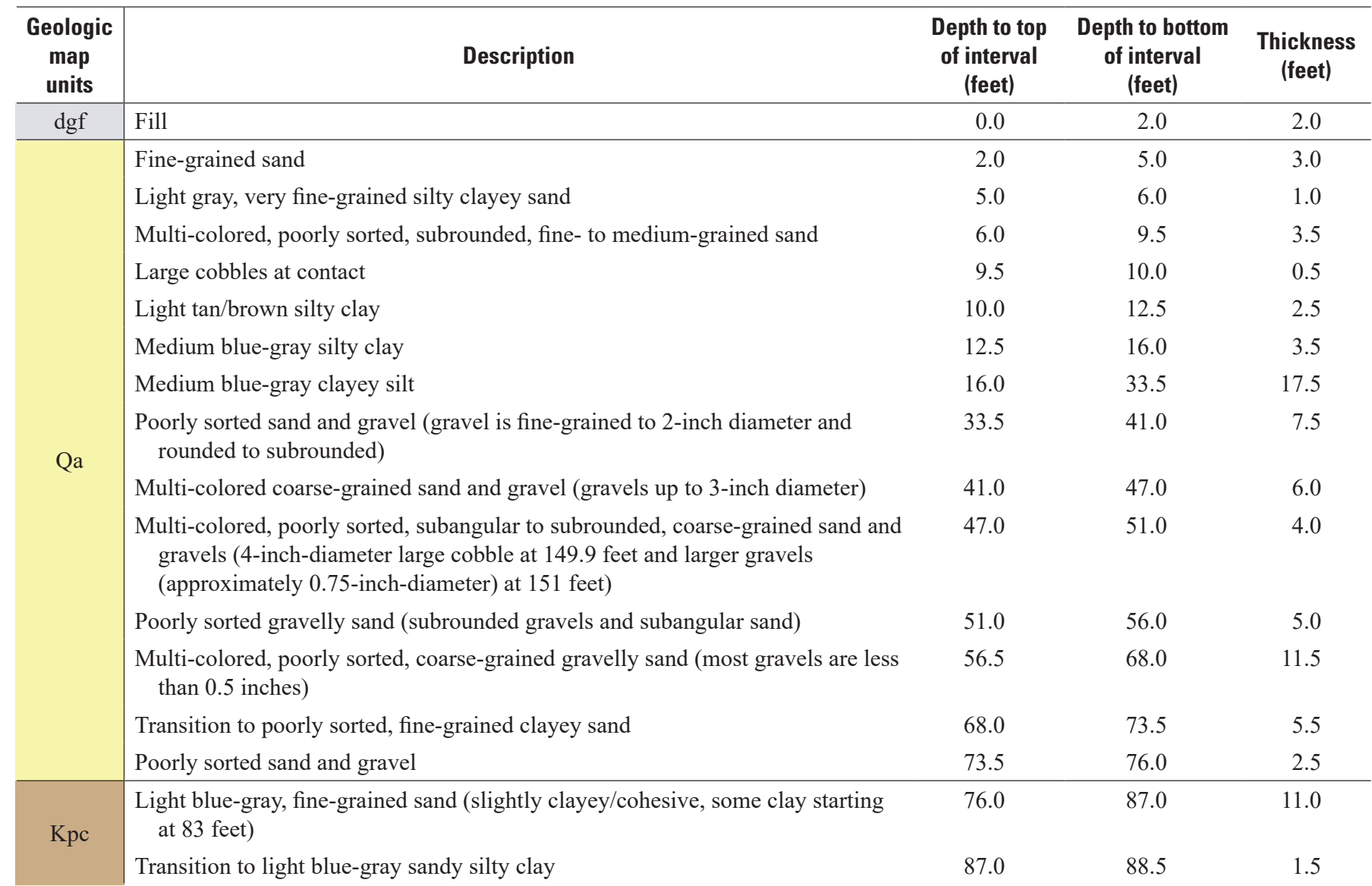


Appendix 1. Lithologic descriptions.-Continued

Site name: SAS-201 (described by C. Dieter)

Altitude: 20.2 feet Total depth: 216 feet

Latitude / Longitude: $38^{\circ} 49^{\prime} 07.93^{\prime \prime} \mathrm{N} / 77^{\circ} 01^{\prime} 05.78^{\prime \prime} \mathrm{W}$

Core used in section D-D'

\begin{tabular}{|c|c|c|c|c|}
\hline $\begin{array}{c}\text { Geologic } \\
\text { map } \\
\text { units }\end{array}$ & Description & $\begin{array}{l}\text { Depth to top } \\
\text { of interval } \\
\text { (feet) }\end{array}$ & $\begin{array}{l}\text { Depth to bottom } \\
\text { of interval } \\
\text { (feet) }\end{array}$ & $\begin{array}{l}\text { Thickness } \\
\text { (feet) }\end{array}$ \\
\hline \multirow{17}{*}{$\mathrm{Kpc}$} & Medium blue-gray with brown and light gray mottled silty clay & 88.5 & 91.0 & 2.5 \\
\hline & Light brown-gray with yellow-brown and brown mottled silty clay & 91.0 & 96.0 & 5.0 \\
\hline & Light gray and red brown mottled clayey silt & 96.0 & 97.5 & 1.5 \\
\hline & Red and light gray mottled silty clay & 97.5 & 100.5 & 3.0 \\
\hline & Medium blue-gray clayey silt & 101.5 & 102.5 & 1.0 \\
\hline & Light gray and brown, very fine-grained mottled sandy clay & 102.5 & 106.0 & 3.5 \\
\hline & Medium brown, blue-gray and brown mottled clay (some silty zones) & 106.0 & 109.0 & 3.0 \\
\hline & Medium brown, blue-gray and brown mottled silty clay & 109.0 & 110.5 & 1.5 \\
\hline & Medium brown and light gray and red-brown mottled silty clay & 117.5 & 120.0 & 2.5 \\
\hline & Medium to dark brown-gray silty clay & 120.0 & 122.5 & 2.5 \\
\hline & Medium to dark red-brown and medium gray mottled silty clay & 122.5 & 126.0 & 3.5 \\
\hline & Medium yellow-brown silty clay (with little light gray mottling) & 126.0 & 127.5 & 1.5 \\
\hline & Medium brown and light gray and light pink-red mottled silty clay & 127.5 & 137.0 & 9.5 \\
\hline & Grades to light blue-gray mottled sandy silt (with organics) & 137.0 & 138.0 & 1.0 \\
\hline & Medium yellow-brown silty clay (trace of sand) & 138.0 & 139.0 & 1.0 \\
\hline & Light gray and red brown mottled silty clay & 139.0 & 140.0 & 1.0 \\
\hline & Mottled clayey silt and silty clay & 140.0 & 143.0 & 3.0 \\
\hline \multirow{7}{*}{ Kps } & Light gray, slightly cohesive, medium-grained sand (few gravels near 186 feet) & 184.5 & 186.5 & 2.0 \\
\hline & $\begin{array}{l}\text { Medium brown-gray sandy silty clay with medium blue-gray horizontal lamina- } \\
\text { tions }\end{array}$ & 186.5 & 188.5 & 2.0 \\
\hline & Medium gray silt (dry and brittle) & 188.5 & 190.5 & 2.0 \\
\hline & Medium brown sandy silty clay & 190.5 & 194.0 & 3.5 \\
\hline & Poorly sorted, fine-grained clayey sand & 194.0 & 195.0 & 1.0 \\
\hline & Medium brown sandy silty clay & 195.0 & 196.0 & 1.0 \\
\hline & $\begin{array}{l}\text { Light gray and red-brown mottled silty clay (only approximately } 6 \text { feet of core } \\
\text { recovered from } 196 \text { to } 216 \text { feet) }\end{array}$ & 196.0 & 216.0 & 20.0 \\
\hline
\end{tabular}


Appendix 1. Lithologic descriptions.-Continued

Site name: SAS-202 (described by C. Dieter)

Altitude: 157.7 feet Total depth: 336 feet

Latitude / Longitude: $38^{\circ} 49^{\prime} 47.03^{\prime \prime} \mathrm{N} / 77^{\circ} 00^{\prime} 52.12^{\prime \prime} \mathrm{W}$

Core used in section D-D'

\begin{tabular}{|c|c|c|c|c|}
\hline $\begin{array}{l}\text { Geologic } \\
\text { map } \\
\text { units }\end{array}$ & Description & $\begin{array}{c}\text { Depth to top } \\
\text { of interval } \\
\text { (feet) }\end{array}$ & $\begin{array}{c}\text { Depth to bottom } \\
\text { of interval } \\
\text { (feet) }\end{array}$ & $\begin{array}{l}\text { Thickness } \\
\text { (feet) }\end{array}$ \\
\hline $\operatorname{dgf}$ & Poorly sorted sand and gravel (fill) & 0.0 & 9.0 & 9.0 \\
\hline \multirow{12}{*}{ Qtt } & $\begin{array}{l}\text { Poorly sorted, sand and gravel (sands are subangular and moderately sorted) } \\
\text { (gravels are } 0.25 \text { to } 1.25 \text { inches in diameter, fewer gravels with depth) }\end{array}$ & 9.0 & 16.0 & 7.0 \\
\hline & $\begin{array}{l}\text { Poorly to moderately sorted, subangular sand with gravels (gravels } 0.25 \text { to } 2.5 \\
\text { inches in diameter) }\end{array}$ & 16.0 & 26.0 & 10.0 \\
\hline & Light gray and oxidized orange silty clay (softer tacky clay) & 26.0 & 29.5 & 3.5 \\
\hline & $\begin{array}{l}\text { Light gray and orange clayey silt (less orange oxidation with depth, trace of } \\
\text { organics around } 35 \text { feet) }\end{array}$ & 29.5 & 35.0 & 5.5 \\
\hline & Transition to light gray sandy silt & 35.0 & 35.5 & 0.5 \\
\hline & Very fine-grained sand & 35.5 & 36.0 & 0.5 \\
\hline & Very fine-grained clayey sand & 36.0 & 42.0 & 6.0 \\
\hline & $\begin{array}{l}\text { Light tan, very fine-grained sand (some clay pockets and 3-inch-thick clay layer } \\
\text { near } 44 \text { feet) }\end{array}$ & 42.5 & 45.5 & 3.0 \\
\hline & Very fine-grained, gravelly sand & 45.5 & 46.0 & 0.5 \\
\hline & Light colored (white/clear), moderately well-sorted, subangular sand & 46.0 & 56.0 & 10.0 \\
\hline & Light colored, fine- to medium-grained sand & 56.0 & 61.0 & 5.0 \\
\hline & Light colored and some gray, medium- to coarse-grained sand & 61.0 & 64.5 & 3.5 \\
\hline \multirow{18}{*}{$\mathrm{Kpc}$} & $\begin{array}{l}\text { Medium gray and flaky oxidized orange mottled silty clay (similar to clay above } \\
\text { approximately } 30 \text { feet) }\end{array}$ & 64.5 & 66.0 & 1.5 \\
\hline & Light gray and orange silty clay & 66.0 & 69.5 & 3.5 \\
\hline & Medium gray and brown-red mottled silty clay & 69.5 & 71.0 & 1.5 \\
\hline & $\begin{array}{l}\text { Medium gray and light brown and yellow/orange mottled silty clay (with trace } \\
\text { of sand) }\end{array}$ & 71.0 & 75.0 & 4.0 \\
\hline & $\begin{array}{l}\text { Light to medium gray and orange and pink silty sandy clay with some organic } \\
\text { matter and lignite (medium-grained sand) }\end{array}$ & 75.0 & 76.0 & 1.0 \\
\hline & Silty sandy clay & 76.0 & 78.0 & 2.0 \\
\hline & Light gray and brown, yellow, and orange mottled clayey silt (trace of sand) & 78.0 & 79.0 & 1.0 \\
\hline & Light gray, yellow-orange and red-brown, highly mottled silty clay with sand & 79.0 & 83.0 & 4.0 \\
\hline & Brown and light gray sandy silty clay & 83.0 & 86.0 & 3.0 \\
\hline & $\begin{array}{l}\text { Light gray, yellow, brown and red-brown (horizontal layered colors) clay (trace } \\
\text { of silt) }\end{array}$ & 86.0 & 96.0 & 10.0 \\
\hline & Light gray, light brown and red-brown mottled clay & 96.0 & 97.5 & 1.5 \\
\hline & Medium gray-brown and light gray and medium pink mottled clay & 97.5 & 102.0 & 4.5 \\
\hline & $\begin{array}{l}\text { Light gray and red-brown mottled silty clay (slightly more red-brown, pink and } \\
\text { gray mottling starting at } 100 \text { feet) }\end{array}$ & 102.0 & 117.0 & 15.0 \\
\hline & Light gray, brown and red mottled silty clay & 118.0 & 120.5 & 2.5 \\
\hline & Red-brown, light gray and pink-red mottled silty clay & 120.5 & 122.5 & 2.0 \\
\hline & Red-brown, light gray and pink-red mottled clayey silt & 122.5 & 125.0 & 2.5 \\
\hline & Transition to light gray clayey silt & 125.0 & 126.0 & 1.0 \\
\hline & Red-brown and light gray mottled clayey silt & 126.0 & 128.0 & 2.0 \\
\hline
\end{tabular}


Appendix 1. Lithologic descriptions.-Continued

Site name: SAS-202 (described by C. Dieter)

Altitude: 157.7 feet Total depth: 336 feet

Latitude / Longitude: $38^{\circ} 49^{\prime} 47.03^{\prime \prime} \mathrm{N} / 77^{\circ} 00^{\prime} 52.12^{\prime \prime} \mathrm{W}$

Core used in section D-D'

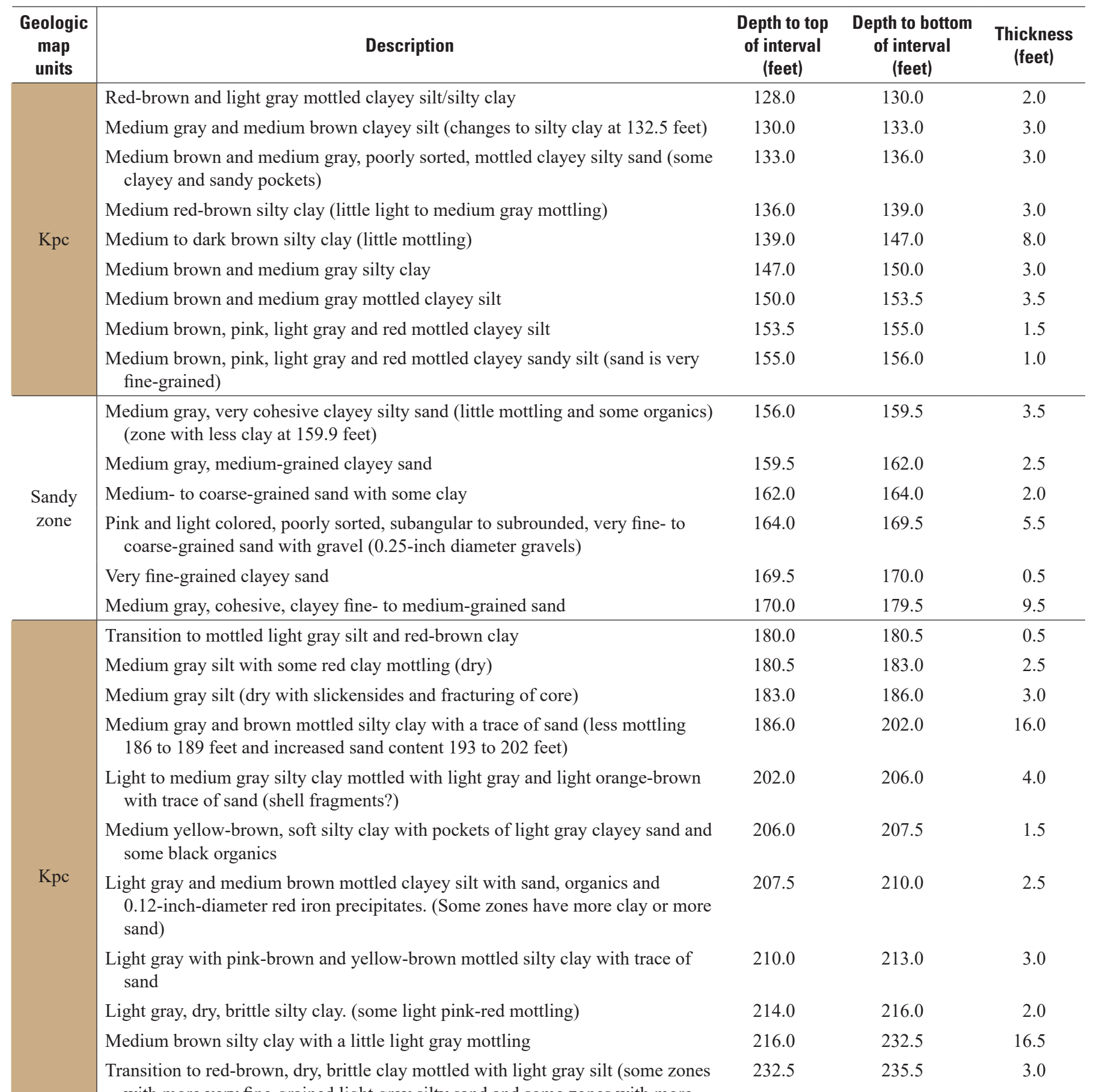

with more very fine-grained light gray silty sand and some zones with more red-brown clayey silt) 
Appendix 1. Lithologic descriptions.-Continued

Site name: SAS-202 (described by C. Dieter)

Altitude: 157.7 feet Total depth: 336 feet

Latitude / Longitude: $38^{\circ} 49^{\prime} 47.03^{\prime \prime} \mathrm{N} / 77^{\circ} 00^{\prime} 52.12^{\prime \prime} \mathrm{W}$

Core used in section D-D'

\begin{tabular}{|c|c|c|c|c|}
\hline $\begin{array}{l}\text { Geologic } \\
\text { map } \\
\text { units }\end{array}$ & Description & $\begin{array}{l}\text { Depth to top } \\
\text { of interval } \\
\text { (feet) }\end{array}$ & $\begin{array}{l}\text { Depth to bottom } \\
\text { of interval } \\
\text { (feet) }\end{array}$ & $\begin{array}{l}\text { Thickness } \\
\text { (feet) }\end{array}$ \\
\hline \multirow{3}{*}{ Kpc } & Poorly sorted clayey sandy silt & 235.5 & 236.0 & 0.5 \\
\hline & Medium brown silty clay & 236.0 & 237.5 & 1.5 \\
\hline & Medium brown clay with little light gray mottling & 237.5 & 241.0 & 3.5 \\
\hline \multirow{9}{*}{$\begin{array}{l}\text { Sandy } \\
\text { zone }\end{array}$} & Transition to cohesive, fine-grained sand with red clay and silt & 241.0 & 242.0 & 1.0 \\
\hline & Fine- to medium-grained clayey sand (some zones more clay or sand) & 242.0 & 245.5 & 3.5 \\
\hline & Light gray silt with pink-brown silty clay & 245.5 & 246.0 & 0.5 \\
\hline & Fine- to medium-grained clayey sand & 246.0 & 248.0 & 2.0 \\
\hline & Light gray and pink-brown mottled clayey sand with some clay pockets & 248.0 & 249.0 & 1.0 \\
\hline & Light gray, fine- to medium-grained clayey sand (less cohesive than above) & 249.0 & 251.0 & 2.0 \\
\hline & Light brown, fine- to medium-grained clayey sand & 251.0 & 252.0 & 1.0 \\
\hline & Coarse- to medium-grained clayey sand (some zones more cohesive) & 252.0 & 253.0 & 1.0 \\
\hline & Poorly sorted, medium-grained clayey sand & 253.0 & 256.0 & 3.0 \\
\hline \multirow{14}{*}{ Kpc } & Light gray, pink-red, brown, yellow and black mottled silty sandy clay & 256.0 & 258.0 & 2.0 \\
\hline & Medium red-brown and brown and little light gray mottled silty sandy clay & 258.0 & 260.0 & 2.0 \\
\hline & $\begin{array}{l}\text { Medium brown and light gray, yellow, red, black and orange mottled clayey silt } \\
\text { with trace of sand }\end{array}$ & 260.0 & 262.5 & 2.5 \\
\hline & Medium red-brown mottled silty clay & 262.5 & 265.5 & 3.0 \\
\hline & $\begin{array}{l}\text { Dark to medium gray and orange mottled clayey silt (with traces of sand and } \\
\text { organics at } 265.5 \text { feet) }\end{array}$ & 265.5 & 273.0 & 7.5 \\
\hline & Transition to medium gray, very fine-grained clayey sand & 273.0 & 276.0 & 3.0 \\
\hline & Light gray and red-brown mottled silty clay & 276.0 & 282.0 & 6.0 \\
\hline & Medium gray and red-brown mottled silty clay & 282.0 & 287.0 & 5.0 \\
\hline & Medium brown-gray, medium gray, and yellow-brown silty clay & 287.0 & 290.0 & 3.0 \\
\hline & Dark gray, medium gray, and yellow-brown silty clay & 290.0 & 294.0 & 4.0 \\
\hline & Light to medium gray and red-brown mottled silty clay & 294.0 & 296.0 & 2.0 \\
\hline & Medium brown-gray silty clay (little mottling) & 296.0 & 300.0 & 4.0 \\
\hline & Medium brown-gray and red-brown and orange mottled silty clay & 300.0 & 306.0 & 6.0 \\
\hline & $\begin{array}{l}\text { Medium brown-gray, red-brown, and orange mottled silty clay with horizontal } \\
\text { color variations of dark brown-red, light gray, medium gray and black (light } \\
\text { gray,very fine-grained sandy zone at } 310 \text { feet) }\end{array}$ & 306.0 & 312.0 & 6.0 \\
\hline \multirow{5}{*}{ Kps } & Medium brown, fine- to medium-grained clayey silty sand & 312.0 & 316.0 & 4.0 \\
\hline & $\begin{array}{l}\text { Medium brown and light gray and pink-red mottled clayey silty sand (zones with } \\
\text { more sand or clay) }\end{array}$ & 316.0 & 319.0 & 3.0 \\
\hline & Medium gray to medium brown mottled clayey silt with sand (brittle) & 319.0 & 320.0 & 1.0 \\
\hline & $\begin{array}{l}\text { Medium gray to medium brown, poorly sorted sandy clayey silt (zones with } \\
\text { more sand or more silt) }\end{array}$ & 320.0 & 326.0 & 6.0 \\
\hline & Mottled gray and red clay with sand, iron oxide clasts, lignite, and slickensides & 326.0 & 336.0 & 10.0 \\
\hline
\end{tabular}


Appendix 1. Lithologic descriptions.-Continued

Site name: SAS-203 (described by C. Dieter)

Altitude: 33.2 feet $\quad$ Total depth: 206 feet

Latitude / Longitude: $38^{\circ} 51^{\prime} 29.30^{\prime \prime} \mathrm{N} / 77^{\circ} 00^{\prime} 10.46^{\prime \prime} \mathrm{W}$

Core used in section D-D'

\begin{tabular}{|c|c|c|c|c|}
\hline $\begin{array}{l}\text { Geologic } \\
\text { map } \\
\text { units }\end{array}$ & Description & $\begin{array}{l}\text { Depth to top } \\
\text { of interval } \\
\text { (feet) }\end{array}$ & $\begin{array}{l}\text { Depth to bottom } \\
\text { of interval } \\
\text { (feet) }\end{array}$ & $\begin{array}{l}\text { Thickness } \\
\text { (feet) }\end{array}$ \\
\hline dgf & No recovery & 0.0 & 10.5 & 10.5 \\
\hline \multirow{25}{*}{ Kpc } & Yellow, orange-brown sandy clay & 10.5 & 12.0 & 1.5 \\
\hline & No recovery & 12.0 & 15.5 & 3.5 \\
\hline & $\begin{array}{l}\text { Yellow-orange-brown poorly sorted sandy, silty, pebbly ( } 0.3 \text { to } 1.0 \text { inch diam- } \\
\text { eter) clay }\end{array}$ & 15.5 & 18.5 & 3.0 \\
\hline & Poorly sorted (very fine-grained sand to pebbles) clayey sand with pink grains & 18.5 & 19.5 & 1.0 \\
\hline & Light bluish gray clay with dark brown and light yellowish gray mottling & 19.5 & 22.0 & 2.5 \\
\hline & No recovery & 22.0 & 25.0 & 3.0 \\
\hline & Light bluish gray clay with light pinkish mottling & 25.0 & 27.5 & 2.5 \\
\hline & $\begin{array}{l}\text { Light bluish gray clayey fine-grained sand. } 3 \text {-inch thick zone near } 30 \text { feet with } \\
\text { dark brown clayey mottling }\end{array}$ & 27.5 & 32.0 & 4.5 \\
\hline & No recovery & 32.0 & 35.5 & 3.5 \\
\hline & Light gray, fine- to medium-grained, poorly sorted clayey (tacky) sand & 35.5 & 42.0 & 6.5 \\
\hline & No recovery & 42.0 & 48.0 & 6.0 \\
\hline & Light bluish-gray clay, mottled with medium pink-brown clay & 48.0 & 55.5 & 7.5 \\
\hline & Light greenish bluish gray silty clay with medium brown mottling & 55.5 & 56.5 & 1.0 \\
\hline & Light bluish gray clay mottled with dark brown clay & 56.5 & 59.0 & 2.5 \\
\hline & Brownish-red clay with light bluish gray, brown and pink mottling & 59.0 & 69.0 & 10.0 \\
\hline & Light gray clay with red mottling & 69.0 & 72.0 & 3.0 \\
\hline & Red and light gray mottled clay (more stiff, dry, and dense than clay above) & 72.0 & 89.0 & 17.0 \\
\hline & $\begin{array}{l}\text { Medium gray with dark pinkish, medium yellow, and brownish-gray mottling. } \\
\text { Clay is hard, tight, and plastic. }\end{array}$ & 89.0 & 96.0 & 7.0 \\
\hline & Light gray and red mottled clay & 96.0 & 124.0 & 28.0 \\
\hline & Light gray and red, multi-colored mottled sandy clay & 124.0 & 126.0 & 2.0 \\
\hline & Multi-colored silty clay with some iron precipitates/nodules near 129 feet. & 126.0 & 131.0 & 5.0 \\
\hline & Multi-colored sandy clay & 131.0 & 137.5 & 6.5 \\
\hline & Light gray, clayey, very fine-grained sand with decreasing clay to 139 feet. & 137.5 & 139.0 & 1.5 \\
\hline & Light gray and red clay to silty clay, mottled & 139.0 & 142.0 & 3.0 \\
\hline & $\begin{array}{l}\text { Light gray and red mottled sandy silty clay (with some zones with more me- } \\
\text { dium- to coarse-grained sand than others) }\end{array}$ & 142.0 & 164.0 & 22.0 \\
\hline Kps & $\begin{array}{l}\text { Light bluish/brownish gray, poorly sorted, subrounded, fine- to medium-grained } \\
\text { clayey sand. Some zones with more clay, some zones with less clay. One } \\
\text { 2-inch translucent yellow rounded cobble }\end{array}$ & 164.0 & 206.0 & 42.0 \\
\hline
\end{tabular}


Appendix 1. Lithologic descriptions.-Continued

Site name: SAS-204 (described by C. Dieter)

Altitude: 158 feet Total depth: 329 feet

Latitude / Longitude: $38^{\circ} 50^{\prime} 55.03^{\prime \prime} \mathrm{N} / 77^{\circ} 00^{\prime} 20.65^{\prime \prime} \mathrm{W}$

Core used in section D-D'

\begin{tabular}{|c|c|c|c|c|}
\hline $\begin{array}{l}\text { Geologic } \\
\text { map } \\
\text { units }\end{array}$ & Description & $\begin{array}{l}\text { Depth to top } \\
\text { of interval } \\
\text { (feet) }\end{array}$ & $\begin{array}{l}\text { Depth to bottom } \\
\text { of interval } \\
\text { (feet) }\end{array}$ & $\begin{array}{l}\text { Thickness } \\
\text { (feet) }\end{array}$ \\
\hline \multirow[b]{2}{*}{ Qtt } & Poorly sorted sand and gravel (gravels from 0.4 to 4 inches in diameter) & 0.0 & 20.0 & 20.0 \\
\hline & $\begin{array}{l}\text { Multicolored, poorly sorted, subangular, medium- to coarse-grained sand (sand } \\
\text { and clay contact at } 24 \text { feet) }\end{array}$ & 20.0 & 24.0 & 4.0 \\
\hline \multirow{30}{*}{ Kpc } & $\begin{array}{l}\text { Medium brown-red clay (little light gray and black mottling between } 24 \text { and } 27 \\
\text { feet) }\end{array}$ & 24.0 & 33.5 & 9.5 \\
\hline & Medium brown-red clay (some gray mottling) & 33.5 & 38.0 & 4.5 \\
\hline & Medium brown-red and light gray mottled clay & 38.0 & 43.0 & 5.0 \\
\hline & Red-brown and light gray mottled silty clay & 43.0 & 47.0 & 4.0 \\
\hline & Medium brown-red and light gray mottled sandy silty clay & 47.0 & 49.5 & 2.5 \\
\hline & Medium brown and light gray mottled silty clay (some dark red coloring) & 49.5 & 55.0 & 5.5 \\
\hline & Coarse-grained sand & 55.0 & 55.5 & 0.5 \\
\hline & Clay & 55.5 & 56.0 & 0.5 \\
\hline & Coarse-grained sand & 56.0 & 56.5 & 0.5 \\
\hline & Light gray, medium brown and red silty sandy clay & 56.5 & 57.0 & 0.5 \\
\hline & Pink-red, light gray and brown mottled silty clay & 57.0 & 60.0 & 3.0 \\
\hline & Red, brown and gray mottled clay & 60.0 & 71.0 & 11.0 \\
\hline & Red-brown and gray mottled silty clay (more silty than above) & 71.0 & 74.0 & 3.0 \\
\hline & Red-brown and gray mottled clay with trace of silt & 74.0 & 77.0 & 3.0 \\
\hline & Red-brown mottled silty clay (little gray mottling) & 77.0 & 80.0 & 3.0 \\
\hline & Red-brown mottled clay (trace of silt) & 80.0 & 83.0 & 3.0 \\
\hline & $\begin{array}{l}\text { Red brown silty clay with trace of sand (some brown and yellow-brown mot- } \\
\text { tling) }\end{array}$ & 83.0 & 87.0 & 4.0 \\
\hline & Red-brown mottled clay (trace of silt) & 87.0 & 94.0 & 7.0 \\
\hline & Medium gray, medium purple, and red-brown, mottled clay & 94.0 & 97.0 & 3.0 \\
\hline & Medium purple and red-brown mottled clayey silt & 97.0 & 103.0 & 6.0 \\
\hline & Medium purple and red-brown mottled silty clay & 103.0 & 108.5 & 5.5 \\
\hline & Medium gray with light gray, purple, and brown mottled clayey silty & 108.5 & 110.5 & 2.0 \\
\hline & $\begin{array}{l}\text { Medium blue-gray with pink, purple, and brown mottled clayey silt (trace of } \\
\text { sand near } 113 \text { feet) }\end{array}$ & 110.5 & 114.0 & 3.5 \\
\hline & Mottled clayey sandy silt (becomes more silty and sandy at 116 feet) & 114.0 & 117.0 & 3.0 \\
\hline & Silt, sand and clay intermixed (pockets of sand, clay, and silt) & 117.0 & 120.0 & 3.0 \\
\hline & Medium- to coarse-grained sand with pockets of silty clay & 120.0 & 121.0 & 1.0 \\
\hline & Light brown and light gray clay & 121.0 & 123.0 & 2.0 \\
\hline & $\begin{array}{l}\text { Poorly sorted, subangular, medium- to fine-grained sand with some zones of } \\
\text { clayey pockets }\end{array}$ & 123.0 & 130.5 & 7.5 \\
\hline & Light gray silty clay with slickensides & 130.5 & 131.0 & 0.5 \\
\hline & Light gray and light purple mottled clay & 131.0 & 133.0 & 2.0 \\
\hline
\end{tabular}


Appendix 1. Lithologic descriptions.-Continued

Site name: SAS-204 (described by C. Dieter)

Altitude: 158 feet Total depth: 329 feet

Latitude / Longitude: $38^{\circ} 50^{\prime} 55.03^{\prime \prime} \mathrm{N} / 77^{\circ} 00^{\prime} 20.65^{\prime \prime} \mathrm{W}$

Core used in section D-D'

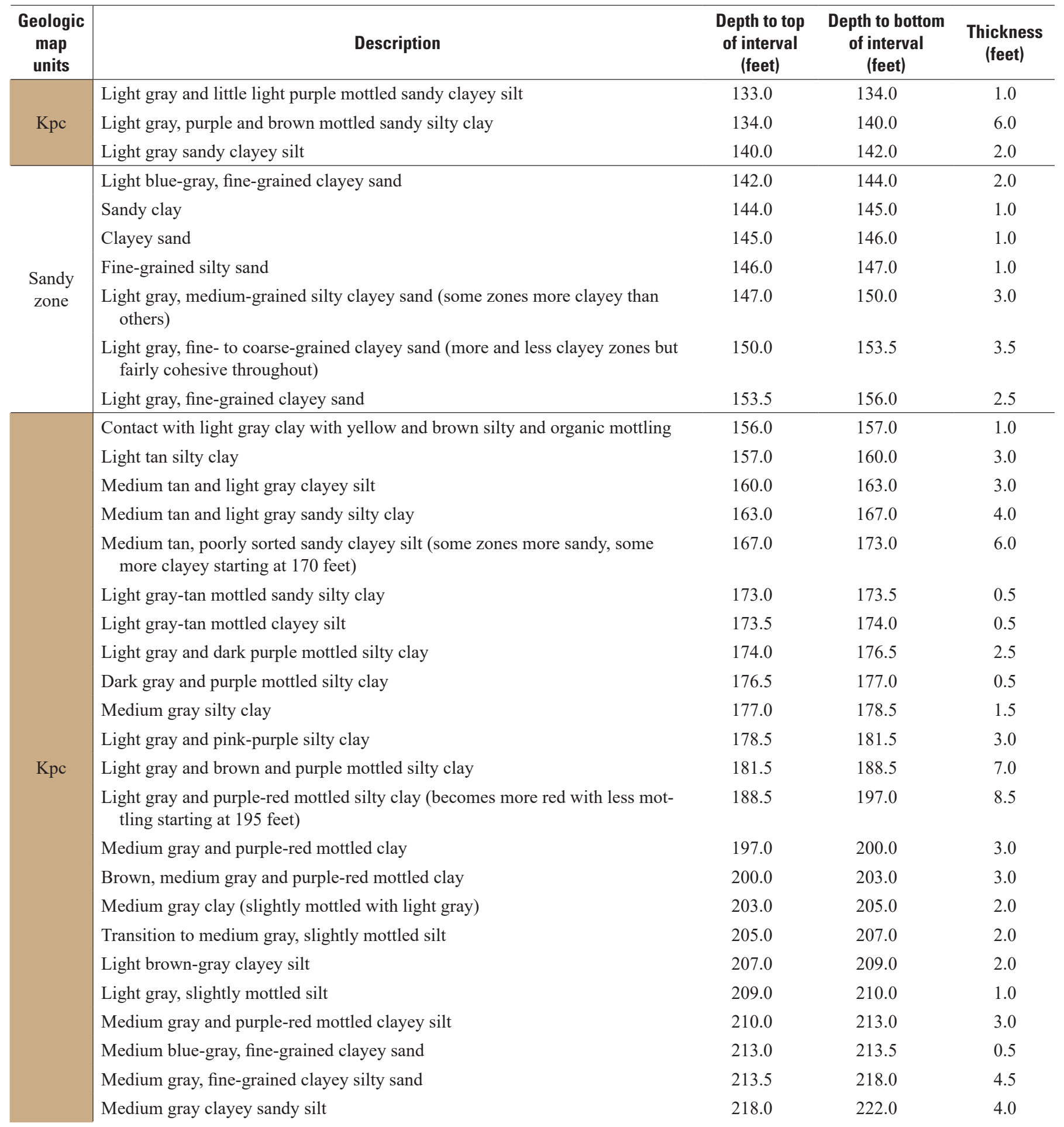


Appendix 1. Lithologic descriptions.-Continued

Site name: SAS-204 (described by C. Dieter)

Altitude: 158 feet Total depth: 329 feet

Latitude / Longitude: $38^{\circ} 50^{\prime} 55.03^{\prime \prime} \mathrm{N} / 77^{\circ} 00^{\prime} 20.65^{\prime \prime} \mathrm{W}$

Core used in section D-D'

\begin{tabular}{|c|c|c|c|c|}
\hline $\begin{array}{l}\text { Geologic } \\
\text { map } \\
\text { units }\end{array}$ & Description & $\begin{array}{l}\text { Depth to top } \\
\text { of interval } \\
\text { (feet) }\end{array}$ & $\begin{array}{l}\text { Depth to bottom } \\
\text { of interval } \\
\text { (feet) }\end{array}$ & $\begin{array}{l}\text { Thickness } \\
\text { (feet) }\end{array}$ \\
\hline \multirow{18}{*}{ Kpc } & $\begin{array}{l}\text { Medium gray clayey fine-grained sand (some zones more clayey and some more } \\
\text { sandy) }\end{array}$ & 222.0 & 232.0 & 10.0 \\
\hline & Medium gray clayey silt & 232.0 & 238.0 & 6.0 \\
\hline & $\begin{array}{l}\text { Medium brown, poorly sorted sandy clayey silt (some red and light gray mot- } \\
\text { tling) }\end{array}$ & 238.0 & 243.5 & 5.5 \\
\hline & Light gray and pink-red mottled clayey silt (brittle and dry) & 243.5 & 245.5 & 2.0 \\
\hline & Red and light gray and brown mottled silty clay (brittle and dry) & 245.5 & 246.0 & 0.5 \\
\hline & Red and light gray mottled silty clay & 246.0 & 247.0 & 1.0 \\
\hline & Red and light gray mottled clayey silt & 247.0 & 252.0 & 5.0 \\
\hline & Grades to silty clayey sand & 252.0 & 255.0 & 3.0 \\
\hline & Light gray and light pink, poorly sorted and mottled silt, sand, and clay & 255.0 & 257.0 & 2.0 \\
\hline & $\begin{array}{l}\text { Medium gray, purple-red, brown, and yellow mottled clayey silt grading to silty } \\
\text { clay }\end{array}$ & 257.0 & 262.0 & 5.0 \\
\hline & Red-brown and gray mottled clayey silt with a trace of sand & 262.0 & 265.0 & 3.0 \\
\hline & Light gray and green-brown mottled clayey silt with a trace of sand & 265.0 & 268.0 & 3.0 \\
\hline & Light gray and red mottled clayey silt & 268.0 & 269.0 & 1.0 \\
\hline & Transition to clayey sandy silt & 269.0 & 272.0 & 3.0 \\
\hline & $\begin{array}{l}\text { Medium red-brown silt with light blue-gray, very fine-grained silty sandy mot- } \\
\text { tling }\end{array}$ & 272.0 & 274.4 & 2.4 \\
\hline & Hard, dry mottled clayey silt (more sandy zones starting at 275 feet) & 274.4 & 277.5 & 3.1 \\
\hline & Medium gray and purple-red mottled silty clay with a trace of sand at 281 feet & 277.5 & 282.0 & 4.5 \\
\hline & Medium gray, brown, and purple-red mottled clayey silt & 282.0 & 283.5 & 1.5 \\
\hline \multirow{10}{*}{ Kps } & $\begin{array}{l}\text { Transition to medium brown-gray, very fine-grained clayey sand (coarse-grained } \\
\text { sand with clay pockets at } 285.5 \text { feet) }\end{array}$ & 283.5 & 287.0 & 3.5 \\
\hline & $\begin{array}{l}\text { Loose, moderately sorted, fine- to medium-grained sand [occasional zones ( } \sim 2 \text { to } \\
4 \text { inches) with clay] }\end{array}$ & 287.0 & 292.0 & 5.0 \\
\hline & $\begin{array}{l}\text { Medium gray, poorly sorted clayey sand (some zones mostly clay, some with } \\
\text { mostly sand starting at } 295.5 \text { feet) }\end{array}$ & 292.0 & 298.5 & 6.5 \\
\hline & Poorly sorted medium-grained sand with low clay content & 298.5 & 302.0 & 3.5 \\
\hline & $\begin{array}{l}\text { Medium gray, poorly sorted, fine-grained clayey sand (fine- to medium-grained } \\
\text { sand starting at } 308 \text { feet and some organic matter at } 311.5 \text { feet) }\end{array}$ & 302.0 & 312.0 & 10.0 \\
\hline & Dark gray and brown silt with trace of mica and organic matter & 312.0 & 316.0 & 4.0 \\
\hline & Medium brown-gray clayey sandy silt & 316.0 & 320.0 & 4.0 \\
\hline & $\begin{array}{l}\text { Medium gray and purple-red and black (layered) mottled clayey sandy silt with } \\
\text { trace of mica and organic matter }\end{array}$ & 320.0 & 324.5 & 4.5 \\
\hline & Fine-grained sand (very little clay or silt) & 324.5 & 328.0 & 3.5 \\
\hline & Poorly sorted, bedded, silty coarse-grained sandy clay & 328.0 & 329.0 & 1.0 \\
\hline
\end{tabular}


Appendix 1. Lithologic descriptions.-Continued

Site name: USNA PW-3 (from Schnabel Engineering Associates, 1995)

Altitude: 14 feet Total depth: 306 feet

Latitude / Longitude: $38^{\circ} 54^{\prime} 34.00^{\prime \prime} \mathrm{N} / 76^{\circ} 57^{\prime} 32.97^{\prime \prime} \mathrm{W}$

Core used in section D-D'

\begin{tabular}{|c|c|c|c|c|}
\hline $\begin{array}{c}\text { Geologic } \\
\text { map } \\
\text { units }\end{array}$ & Description & $\begin{array}{l}\text { Depth to top } \\
\text { of interval } \\
\text { (feet) }\end{array}$ & $\begin{array}{l}\text { Depth to bottom } \\
\text { of interval } \\
\text { (feet) }\end{array}$ & $\begin{array}{l}\text { Thickness } \\
\text { (feet) }\end{array}$ \\
\hline \multirow{6}{*}{ Kpc } & Tan, fine to medium grained sand & 0.0 & 10.0 & 10.0 \\
\hline & Fat clay, gray with thin sand layers & 10.0 & 40.0 & 30.0 \\
\hline & Brown, fine silty sand & 40.0 & 50.0 & 10.0 \\
\hline & Red-brown and gray lean clay & 50.0 & 100.0 & 50.0 \\
\hline & Brown fine grained sand & 120.0 & 130.0 & 10.0 \\
\hline & Red-brown and gray lean clay with fine to medium grained sand & 130.0 & 140.0 & 10.0 \\
\hline \multirow{3}{*}{ Kps } & $\begin{array}{l}\text { Gray fine to medium grained sand (lignite below } 170 \text { feet, clay layer from } 170 \text { to } \\
172 \text { feet) }\end{array}$ & 140.0 & 200.0 & 60.0 \\
\hline & $\begin{array}{l}\text { Gray, subangular to subrounded, medium to course sand (probable boulder at } \\
289 \text { feet) }\end{array}$ & 270.0 & 290.0 & 20.0 \\
\hline & Red and gray lean clay with sand and lignite (Rock at 306 feet) & 290.0 & 306.0 & 16.0 \\
\hline bedrock & & & & \\
\hline
\end{tabular}

Appendix 1. Lithologic descriptions.-Continued

Site name: WE Ba 9 (described by C. Klohe on March 10, 2006)

Altitude: 81.26 feet Total depth: 24 feet

Latitude / Longitude: $38^{\circ} 56^{\prime} 06.5^{\prime \prime} \mathrm{N} / 76^{\circ} 58^{\prime} 41.4^{\prime \prime} \mathrm{W}$

\begin{tabular}{|c|c|c|c|c|}
\hline $\begin{array}{l}\text { Geologic } \\
\text { map } \\
\text { units }\end{array}$ & Description & $\begin{array}{l}\text { Depth to top } \\
\text { of interval } \\
\text { (feet) }\end{array}$ & $\begin{array}{l}\text { Depth to bottom } \\
\text { of interval } \\
\text { (feet) }\end{array}$ & $\begin{array}{c}\text { Thickness } \\
\text { (feet) }\end{array}$ \\
\hline \multirow[b]{2}{*}{$\operatorname{dgf}$} & $\begin{array}{l}\text { Soil. Fill. Brown to red-brown poorly sorted silt (with sand, gravel, and clay). } \\
\text { Some zones contain quartz pebbles (0.4- to 1.6-inch diameter). Some dark } \\
\text { minerals. }\end{array}$ & 0.0 & 2.0 & 2.0 \\
\hline & $\begin{array}{l}\text { Medium to light brown, silty sand, silt, and sandy silt. 2-inch layer of unconsoli- } \\
\text { dated green schist, light-tan sand, pebbles, and dark minerals. } 3 \text {-inch layer of } \\
\text { light-tan, well-sorted, silty fine-grained sand. Thin layer of light tan clay with } \\
\text { dark gray stone (1-inch diameter). ( } 3.5 \text { feet of core recovery) }\end{array}$ & 2.0 & 4.0 & 2.0 \\
\hline \multirow{2}{*}{$\mathrm{Kpc}$} & $\begin{array}{l}\text { Mottled, poorly sorted clay with some zones of high percent light gray sand. } \\
\text { Includes dark gray, dark brown, light gray, light brown, and maroon clays. At } \\
7 \text { feet, poorly sorted zone of dark gray clasts }\end{array}$ & 4.0 & 7.0 & 3.0 \\
\hline & $\begin{array}{l}\text { Medium brown clay mottled with light gray, red, and yellow clay. } 0.1 \text { - to } \\
0.3 \text {-inch-diameter twig in core near } 8 \text { feet on top of zone with large crystalline } \\
\text { rock chunk. }\end{array}$ & 7.0 & 8.0 & 1.0 \\
\hline
\end{tabular}


Appendix 1. Lithologic descriptions.-Continued

Site name: WE Ba 9 (described by C. Klohe on March 10, 2006)

Altitude: 81.26 feet Total depth: 24 feet

Latitude / Longitude: $38^{\circ} 56^{\prime} 06.5^{\prime \prime} \mathrm{N} / 76^{\circ} 58^{\prime} 41.4^{\prime \prime} \mathrm{W}$

\begin{tabular}{|c|c|c|c|c|}
\hline $\begin{array}{c}\text { Geologic } \\
\text { map } \\
\text { units }\end{array}$ & Description & $\begin{array}{l}\text { Depth to top } \\
\text { of interval } \\
\text { (feet) }\end{array}$ & $\begin{array}{l}\text { Depth to bottom } \\
\text { of interval } \\
\text { (feet) }\end{array}$ & $\begin{array}{l}\text { Thickness } \\
\text { (feet) }\end{array}$ \\
\hline \multirow{5}{*}{ Kps } & $\begin{array}{l}\text { Medium-brown, fining upward sequence of well-sorted, very fine silty sand, fine } \\
\text { sand, and well-rounded quartzite cobbles up to } 0.25 \text {-inch diameter. }\end{array}$ & 8.0 & 10.5 & 2.5 \\
\hline & $\begin{array}{l}\text { Black and white speckled to light gray to black and white speckled, poorly } \\
\text { sorted, silty, fine- to medium-grained sand. }\end{array}$ & 10.5 & 12.0 & 1.5 \\
\hline & $\begin{array}{l}\text { Light-orange and tan, poorly sorted, medium-grained sand. Sand grains are } \\
\text { multicolored (pinks, whites, grays, medium browns, and dark browns). }\end{array}$ & 14.0 & 16.0 & 2.0 \\
\hline & Poorly sorted, medium- to coarse-grained sand with white residue. & 16.0 & 17.0 & 1.0 \\
\hline & $\begin{array}{l}\text { Light tan to white, slightly mottled silt. Some zones with very fine, well-sorted } \\
\text { sand. }\end{array}$ & 17.0 & 20.0 & 3.0 \\
\hline
\end{tabular}

Appendix 1. Lithologic descriptions.-Continued

Site name: WE Ba 10 (described by C. Klohe on March 6, 2006)

Altitude: 74.43 feet Total depth: 20 feet

Latitude / Longitude: $38^{\circ} 55^{\prime} 34.4^{\prime \prime} \mathrm{N} / 76^{\circ} 58^{\prime} 21.4^{\prime \prime} \mathrm{W}$

\begin{tabular}{|c|c|c|c|c|}
\hline $\begin{array}{c}\text { Geologic } \\
\text { map } \\
\text { units }\end{array}$ & Description & $\begin{array}{l}\text { Depth to top } \\
\text { of interval } \\
\text { (feet) }\end{array}$ & $\begin{array}{l}\text { Depth to bottom } \\
\text { of interval } \\
\text { (feet) }\end{array}$ & $\begin{array}{l}\text { Thickness } \\
\text { (feet) }\end{array}$ \\
\hline \multirow{2}{*}{$\operatorname{dgf}$} & $\begin{array}{l}\text { Light orange-brown, sandy, clayey silt. Poorly sorted. Some pebbles. Some } \\
\text { zones with clay or organics. ( } 3 \text { feet of recovery) }\end{array}$ & 0.0 & 4.0 & 4.0 \\
\hline & $\begin{array}{l}\text { Light orange-brown, silty, clayey, fine-grained sand with some pebbles. ( } 3.5 \text { feet } \\
\text { of core recovery) }\end{array}$ & 4.0 & 8.0 & 4.0 \\
\hline \multirow[t]{3}{*}{ Qa } & Light orange-brown, silty sand with organic material. & 10.0 & 11.0 & 1.0 \\
\hline & Light orangish-brown silty sand with organic material. & 11.0 & 12.0 & 1.0 \\
\hline & Medium brown, fine- to medium-grained, silty sand. Wet. & 12.0 & 14.0 & 2.0 \\
\hline
\end{tabular}


Appendix 1. Lithologic descriptions.-Continued

Site name: WE Ca 6 (Hansen, 1968)

Altitude: 80 feet Total depth: 340 feet

Latitude / Longitude: $38^{\circ} 53^{\prime} 30.00^{\prime \prime} \mathrm{N} / 76^{\circ} 59^{\prime} 46.98^{\prime \prime} \mathrm{W}$

\begin{tabular}{|c|c|c|c|c|}
\hline $\begin{array}{c}\text { Geologic } \\
\text { map } \\
\text { units }\end{array}$ & Description & $\begin{array}{c}\text { Depth to top } \\
\text { of interval } \\
\text { (feet) }\end{array}$ & $\begin{array}{l}\text { Depth to bottom } \\
\text { of interval } \\
\text { (feet) }\end{array}$ & $\begin{array}{c}\text { Thickness } \\
\text { (feet) }\end{array}$ \\
\hline Qfe & Sand, brown and gravel & 0.0 & 35.0 & 35.0 \\
\hline \multirow{7}{*}{$\mathrm{Kpc}$} & Clay, brown & 35.0 & 75.0 & 40.0 \\
\hline & Clay, brown and sand & 75.0 & 100.0 & 25.0 \\
\hline & Sand, yellow and clay & 100.0 & 105.0 & 5.0 \\
\hline & Clay, blue & 105.0 & 158.0 & 53.0 \\
\hline & Clay, sandy; blue & 158.0 & 175.0 & 17.0 \\
\hline & Sand, blue and clay & 175.0 & 196.0 & 21.0 \\
\hline & Clay, "tough"; blue & 196.0 & 242.0 & 46.0 \\
\hline \multirow{5}{*}{ Kps } & Sand & 242.0 & 256.0 & 14.0 \\
\hline & Clay, "tough"; blue & 256.0 & 272.0 & 16.0 \\
\hline & Sand & 272.0 & 288.0 & 16.0 \\
\hline & Clay, "tough"; blue & 288.0 & 307.0 & 19.0 \\
\hline & Sand and gravel & 307.0 & 328.0 & 21.0 \\
\hline bedrock & Granite (?) & 328.0 & 340.0 & 12.0 \\
\hline
\end{tabular}

Appendix 1. Lithologic descriptions.-Continued

Site name: WE Ca 30 (Tenbus, 2003)

Altitude: 3 feet Total depth: 30.5 feet

Latitude / Longitude: $38^{\circ} 54^{\prime} 05.8^{\prime \prime} \mathrm{N} / 76^{\circ} 57^{\prime} 34.2^{\prime \prime} \mathrm{W}$

\begin{tabular}{|c|c|c|c|c|}
\hline $\begin{array}{c}\text { Geologic } \\
\text { map } \\
\text { units }\end{array}$ & Description & $\begin{array}{c}\text { Depth to top } \\
\text { of interval } \\
\text { (feet) }\end{array}$ & $\begin{array}{l}\text { Depth to bottom } \\
\text { of interval } \\
\text { (feet) }\end{array}$ & $\begin{array}{l}\text { Thickness } \\
\text { (feet) }\end{array}$ \\
\hline \multirow{11}{*}{$\begin{array}{l}\text { Qa } \\
\text { and } \\
\text { Qt }\end{array}$} & $\begin{array}{l}\text { Clayey silt (ML), dark greenish gray ( } 5 \mathrm{Y} 4 / 1) \text {, with thin, nearly black streaks of } \\
\text { organic silt (OL) from } 0.3 \text { to } 1.5 \mathrm{ft}\end{array}$ & 0.0 & 3.1 & 3.1 \\
\hline & $\begin{array}{l}\text { Organic silt }(\mathrm{OL}) \text {, very dark gray }(2.5 \mathrm{Y} 3 / 0) \text {, soft, seems to have a faint organic } \\
\text { or petroleum odor }\end{array}$ & 3.1 & 4.0 & 0.9 \\
\hline & Clayey silt (ML), dark gray (5Y 4/0) & 4.0 & 5.3 & 1.3 \\
\hline & Silt with fine sand (ML), dark gray (5Y 4/0) & 5.3 & 5.5 & 0.2 \\
\hline & Fine sand (SP), dark gray (5Y 5/2), some lignite at $7.5 \mathrm{ft}$ & 5.5 & 7.5 & 2.0 \\
\hline & $\begin{array}{l}\text { Silt to clayey silt (ML), dark gray ( } 5 \mathrm{Y} 5 / 2) \text {, slight color change at } 8.5 \mathrm{ft} \text { to dark } \\
\text { gray }(5 \mathrm{Y} 4 / 1)\end{array}$ & 7.5 & 9.5 & 2.0 \\
\hline & Silty clay (CL), dark gray (5Y 4/0) & 9.5 & 11.8 & 2.3 \\
\hline & Sandy clay (SC), same as above with medium sand & 11.8 & 12.0 & 0.2 \\
\hline & $\begin{array}{l}\text { Silty clay }(\mathrm{CL}) \text {, gray }(5 \mathrm{Y} 6 / 0) \text {, stiff, with a gradual transition to very stiff from } \\
13.0 \text { to } 13.5 \mathrm{ft}\end{array}$ & 12.0 & 13.5 & 1.5 \\
\hline & $\begin{array}{l}\text { Silty clay (CL), marbled olive and brown, dry, very stiff, becomes hard clay } \\
\text { from } 17.9 \text { to } 18.0 \mathrm{ft}\end{array}$ & 13.5 & 18.0 & 4.5 \\
\hline & Clay $(\mathrm{CL})$, gray $(\% \mathrm{Y} 6 / 0)$, medium stiff & 18.0 & 19.8 & 1.8 \\
\hline
\end{tabular}


Appendix 1. Lithologic descriptions.-Continued

Site name: WE Ca 30 (Tenbus, 2003)

Altitude: 3 feet $\quad$ Total depth: 30.5 feet

Latitude / Longitude: $38^{\circ} 54^{\prime} 05.8^{\prime \prime} \mathrm{N} / 76^{\circ} 57^{\prime} 34.2^{\prime \prime} \mathrm{W}$

\begin{tabular}{|c|c|c|c|c|}
\hline $\begin{array}{l}\text { Geologic } \\
\text { map } \\
\text { units }\end{array}$ & Description & $\begin{array}{l}\text { Depth to top } \\
\text { of interval } \\
\text { (feet) }\end{array}$ & $\begin{array}{l}\text { Depth to bottom } \\
\text { of interval } \\
\text { (feet) }\end{array}$ & $\begin{array}{l}\text { Thickness } \\
\text { (feet) }\end{array}$ \\
\hline \multirow{5}{*}{$\begin{array}{l}\text { Qa } \\
\text { and } \\
\text { Qt }\end{array}$} & $\begin{array}{l}\text { Gravel, sand, and silt mixture (GM), variegated color, top is reddish yellow ( } 7.5 \\
\text { YR 6/8), color changes to pale olive ( } 5 \text { Y 6/3) from } 21.0 \text { to } 24.5 \mathrm{ft} \text {. Contains } \\
\text { cobbles as large as } 60 \text { millimeters in diameter }\end{array}$ & 19.8 & 24.5 & 4.7 \\
\hline & Sandy clay (SC), variegated & 24.5 & 24.8 & 0.3 \\
\hline & $\begin{array}{l}\text { Clay, sand, and gravel mix (GC), light yellowish brown }(2.5 \mathrm{Y} 6 / 4) \text {, gravel sizes } \\
\text { to } 25 \text { millimeters }\end{array}$ & 24.8 & 25.0 & 0.2 \\
\hline & Sandy clay (SC), pale olive (5Y 6/2) & 25.0 & 26.5 & 1.5 \\
\hline & Poorly graded fine sand (SP), pale olive (5Y 6/2) & 26.5 & 29.5 & 3.0 \\
\hline $\mathrm{Kpc}$ & Clay (CL), red and olive marbled, very stiff & 29.5 & 30.5 & 1.0 \\
\hline
\end{tabular}

Appendix 1. Lithologic descriptions.-Continued

Site name: WE Ca 32, MW-4 (from DCWRRC, 1993a)

Altitude: 80 feet Total depth: 42 feet

Latitude / Longitude: $38^{\circ} 53^{\prime} 32.00^{\prime \prime} \mathrm{N} / 76^{\circ} 59^{\prime} 46.98^{\prime \prime} \mathrm{W}$

\begin{tabular}{c|lccc}
\hline $\begin{array}{c}\text { Geologic } \\
\text { map } \\
\text { units }\end{array}$ & \multicolumn{1}{|c}{ Description } & $\begin{array}{c}\text { Depth to top } \\
\text { of interval } \\
\text { (feet) }\end{array}$ & $\begin{array}{c}\text { Depth to bottom } \\
\text { of interval } \\
\text { (feet) }\end{array}$ & $\begin{array}{c}\text { Thickness } \\
\text { (feet) }\end{array}$ \\
\hline dgf & Brown, damp, sand and fill material & 0.0 & 5.0 & 5.0 \\
\hline \multirow{4}{*}{} & Brown, damp, medium grained sand & 5.0 & 6.5 & 1.5 \\
& No Sample & 6.5 & 10.0 & 3.5 \\
& Brown, damp, medium grained sand with & 10.0 & 11.5 & 1.5 \\
& No Sample & 11.5 & 15.0 & 3.5 \\
& Brown, damp to wet, gravelly sand with some pebbles & 15.0 & 16.5 & 1.5 \\
& No Sample & 16.5 & 20.0 & 3.5 \\
& Moist gravel (quartz pebbles) & No Sample & 1.5 & 1.5 \\
& Brown, wet sand and gravel & 20.0 & 21.5 & 3.5 \\
& No Sample & 21.5 & 25.0 & 1.5 \\
& Brown, wet sand with gravel & 25.5 & 3.5 \\
& No Sample & 25.0 & 30.0 & 1.5 \\
& Brown, wet sand with gravel & 26.5 & 31.5 & 3.5 \\
& No Sample & 30.0 & 35.0 & 1.5 \\
\hline Kpc & Gray, damp to wet silty clay & 31.5 & 36.5 & 3.5 \\
\hline
\end{tabular}


Appendix 1. Lithologic descriptions.-Continued

Site name: WE Ca 33 (described by C. Klohe on August 5, 2005)

Altitude: 67.75 feet Total depth: 40 feet

Latitude / Longitude: $38^{\circ} 53^{\prime} 49.8^{\prime \prime} \mathrm{N} / 76^{\circ} 59^{\prime} 28.3^{\prime \prime} \mathrm{W}$

\begin{tabular}{|c|c|c|c|c|}
\hline $\begin{array}{c}\text { Geologic } \\
\text { map } \\
\text { units }\end{array}$ & Description & $\begin{array}{c}\text { Depth to top } \\
\text { of interval } \\
\text { (feet) }\end{array}$ & $\begin{array}{c}\text { Depth to bottom } \\
\text { of interval } \\
\text { (feet) }\end{array}$ & $\begin{array}{c}\text { Thickness } \\
\text { (feet) }\end{array}$ \\
\hline \multirow{4}{*}{ Qfe } & Gravels and tan, silty sand. & 0.0 & 1.5 & 1.5 \\
\hline & Tan brown silty sand with gravels. & 1.5 & 12.0 & 10.5 \\
\hline & Brown silty sand. & 12.0 & 16.5 & 4.5 \\
\hline & Tan silty fine sand with well-sorted gravels & 16.5 & 30 & 13.5 \\
\hline $\mathrm{Kpc}$ & Tan silty clay. & 38.0 & 40.0 & 2.0 \\
\hline
\end{tabular}

Appendix 1. Lithologic descriptions.-Continued

Site name: WE Ca 34 (described by C. Klohe on August 10, 2005)

Altitude: 19.61 feet Total depth: 45.5 feet

Latitude / Longitude: $38^{\circ} 52^{\prime} 45.6^{\prime \prime} \mathrm{N} / 76^{\circ} 58^{\prime} 35.1^{\prime \prime} \mathrm{W}$

\begin{tabular}{|c|c|c|c|c|}
\hline $\begin{array}{c}\text { Geologic } \\
\text { map } \\
\text { units }\end{array}$ & Description & $\begin{array}{l}\text { Depth to top } \\
\text { of interval } \\
\text { (feet) }\end{array}$ & $\begin{array}{c}\text { Depth to bottom } \\
\text { of interval } \\
\text { (feet) }\end{array}$ & $\begin{array}{l}\text { Thickness } \\
\text { (feet) }\end{array}$ \\
\hline \multirow{3}{*}{$\operatorname{dgf}$} & Sod and topsoil. & 0.0 & 0.5 & 0.5 \\
\hline & Tan silty sand with gravels. & 0.5 & 1.5 & 1.0 \\
\hline & Yellowish-brown silty sand. & 1.5 & 4.0 & 2.5 \\
\hline \multirow{4}{*}{ Qa } & Tan silty sand with poorly sorted gravel. & 4.0 & 5.0 & 1.0 \\
\hline & Poorly sorted gravels with little tan silty sand. & 6.0 & 8.0 & 2.0 \\
\hline & Grayish-tan silty sand with clay mixed in. Less gravel than interval above. & 8.0 & 11.5 & 3.5 \\
\hline & $\begin{array}{l}\text { Greenish-gray, silty, clayey sand with little gravel. Lost circulation at } 17 \text { feet. } \\
\text { (possible water). }\end{array}$ & 11.5 & 21.0 & 9.5 \\
\hline \multirow{2}{*}{$\mathrm{Kpc}$} & Gray, silty, clayey sand (no gravel). & 21.0 & 31.0 & 10.0 \\
\hline & Gray clay (core sample). & 43.5 & 45.5 & 2.0 \\
\hline
\end{tabular}


Appendix 1. Lithologic descriptions.-Continued

Site name: WE Ca 35, USNA PW-2 (from A.C. Schultes of Maryland, Inc. [n.d.], Job \#2616)

Altitude: 149.6 feet $\quad$ Total depth: 265 feet

Latitude / Longitude: $38^{\circ} 54^{\prime} 29.20^{\prime \prime} \mathrm{N} / 76^{\circ} 58^{\prime} 36.00^{\prime \prime} \mathrm{W}$

\begin{tabular}{|c|c|c|c|c|}
\hline $\begin{array}{c}\text { Geologic } \\
\text { map } \\
\text { units }\end{array}$ & Description & $\begin{array}{c}\text { Depth to top } \\
\text { of interval } \\
\text { (feet) }\end{array}$ & $\begin{array}{l}\text { Depth to bottom } \\
\text { of interval } \\
\text { (feet) }\end{array}$ & $\begin{array}{l}\text { Thickness } \\
\text { (feet) }\end{array}$ \\
\hline $\operatorname{dgf}$ & Fine clay sand with clay. Subangular to subrounded, brown & 0.0 & 5.0 & 5.0 \\
\hline \multirow{3}{*}{ Kpc } & Clay with sand. Brown and gray & 5.0 & 90.0 & 85.0 \\
\hline & $\begin{array}{l}\text { Clay with sand. Red-brown. Sand layers at 115-117, 122-124, and below } 150 \\
\text { feet. }\end{array}$ & 90.0 & 168.0 & 78.0 \\
\hline & Fine clayey sand with clay lenses. Red-brown & 168.0 & 178.0 & 10.0 \\
\hline Kps & Fine to medium sand with clay lenses. Clay layers below 255 feet & 178.0 & 265.0 & 87.0 \\
\hline
\end{tabular}

Appendix 1. Lithologic descriptions.-Continued

Site name: WE Ca 38 (described by C. Klohe on March 13, 2006)

Altitude: 45 feet Total depth: 24.0 feet

Latitude / Longitude: $38^{\circ} 54^{\prime} 16.07^{\prime \prime} \mathrm{N} / 76^{\circ} 58^{\prime} 15.54^{\prime \prime} \mathrm{W}$

\begin{tabular}{|c|c|c|c|c|}
\hline $\begin{array}{l}\text { Geologic } \\
\text { map } \\
\text { units }\end{array}$ & Description & $\begin{array}{l}\text { Depth to top } \\
\text { of interval } \\
\text { (feet) }\end{array}$ & $\begin{array}{l}\text { Depth to bottom } \\
\text { of interval } \\
\text { (feet) }\end{array}$ & $\begin{array}{l}\text { Thickness } \\
\text { (feet) }\end{array}$ \\
\hline $\operatorname{dgf}$ & $\begin{array}{l}\text { Soil. Poorly sorted, tan, sandy silt with gravels. Some quartzite gravels } 0.25 \text { - to } \\
\text { 1.5-inch diameter. Red-brown silt with gravels. ( } 2.5 \text { feet recovery) }\end{array}$ & 0.0 & 4.0 & 4.0 \\
\hline \multirow{10}{*}{$\mathrm{Kpc}$} & $\begin{array}{l}\text { Light reddish-brown silty clay (slightly mottled with light yellowish-orange } \\
\text { clay). Organic matter visible at } 5.5 \text { feet. Organic matter with black mottling } \\
\text { from } 6 \text { to } 8 \text { feet. }\end{array}$ & 4.0 & 8.0 & 4.0 \\
\hline & $\begin{array}{l}\text { Red-brown silty clay with zone of light brown/tan silty sand at approximately } \\
10 \text { feet. }\end{array}$ & 8.0 & 10.0 & 2.0 \\
\hline & Reddish-brown clay. & 10.0 & 11.0 & 1.0 \\
\hline & Red clay. & 11.0 & 12.0 & 1.0 \\
\hline & No recovery. & 12.0 & 16.0 & 4.0 \\
\hline & Light red-brown, sandy silt with a trace amount of organic matter. & 16.0 & 18.5 & 2.5 \\
\hline & Light brown, orange and red mottled silty clay. Some organic matter. & 18.5 & 20 & 1.5 \\
\hline & Light brown to light gray, very well-sorted, very fine-grained, clayey, silty sand. & 20.0 & 21.5 & 1.5 \\
\hline & Light gray clay and red and gray mottled clay. & 21.5 & 23 & 1.5 \\
\hline & Yellow,-gray,-green, brown and light gray mottled clay. & 23.0 & 24.0 & 1.0 \\
\hline
\end{tabular}


Appendix 1. Lithologic descriptions.-Continued

Site name: WE Cb 7 (Tenbus, 2003)

Altitude: 4 feet Total depth: 27.9 feet

Latitude / Longitude: $38^{\circ} 54^{\prime} 59.5^{\prime \prime} \mathrm{N} / 76^{\circ} 56^{\prime} 34.0^{\prime \prime} \mathrm{W}$

\begin{tabular}{|c|c|c|c|c|}
\hline $\begin{array}{l}\text { Geologic } \\
\text { map } \\
\text { units }\end{array}$ & Description & $\begin{array}{l}\text { Depth to top } \\
\text { of interval } \\
\text { (feet) }\end{array}$ & $\begin{array}{l}\text { Depth to bottom } \\
\text { of interval } \\
\text { (feet) }\end{array}$ & $\begin{array}{l}\text { Thickness } \\
\text { (feet) }\end{array}$ \\
\hline \multirow{9}{*}{$\begin{array}{l}\text { Qa } \\
\text { and } \\
\text { Qt }\end{array}$} & $\begin{array}{l}\text { Gravel and sand mixture (GP), light yellowish brown }(2.5 \mathrm{Y} 6 / 3) \text {. Sand is coarse, } \\
\text { subrounded, with cobbles up to } 35 \text { millimeters. Occasional small ( } \sim 5 \text { millime- } \\
\text { ters) anthropogenic glass fragments noted }\end{array}$ & 0.0 & 1.7 & 1.7 \\
\hline & $\begin{array}{l}\text { Gravel, sand, and silt mixture (GM), light yellowish brown }(2.5 \mathrm{Y} 5 / 3) \text {, cobbles } \\
\text { up to } 50 \text { millimeters. Small glass fragment near } 2.8 \mathrm{ft}\end{array}$ & 1.7 & 2.8 & 1.1 \\
\hline & Silty clay (CL), grayish brown (2.5Y 5/2), soft & 3.5 & 6.8 & 3.3 \\
\hline & $\begin{array}{l}\text { Fine silty sand (SM), color not uniform, generally dark gray to dark olive. Pre- } \\
\text { dominantly very dark gray }(5 \mathrm{Y} 3 / 0)\end{array}$ & 6.8 & 8.1 & 1.3 \\
\hline & $\begin{array}{l}\text { Medium clean sand (SP) with lignite chunks (possibly old leafy material), light } \\
\text { gray }(5 \mathrm{Y} 7 / 2)\end{array}$ & 8.1 & 8.7 & 0.6 \\
\hline & $\begin{array}{l}\text { Gravel-sand mixture }(\mathrm{GW}) \text {, same as above, red }(2.5 \mathrm{YR} 4 / 8) \text { mixed with pale } \\
\text { yellow }(2.5 \mathrm{Y} 7 / 4)\end{array}$ & 12.0 & 13.0 & 1.0 \\
\hline & $\begin{array}{l}\text { Fine poorly graded sand (SP), very pale brown }(10 \mathrm{YR} 7 / 3) \text {, no clay or silt, sub- } \\
\text { rounded grains, with a thin layer of fine sand and gravel, red }(2.5 \mathrm{YR} 4 / 8) \text { from } \\
14.0 \text { to } 14.1 \mathrm{ft} \text { below land surface }\end{array}$ & 13.0 & 25.2 & 12.2 \\
\hline & Same material as above, color includes reddish brown mottles $(2.5 \mathrm{YR} 5 / 3)$ & 25.2 & 25.7 & 0.5 \\
\hline & $\begin{array}{l}\text { Fine poorly graded sand (SP), very pale brown (10YR } 7 / 3) \text {, no clay or silt, } \\
\text { subrounded grains }\end{array}$ & 25.7 & 27.9 & 2.2 \\
\hline
\end{tabular}

Appendix 1. Lithologic descriptions.-Continued

Site name: WE Cb 8, MW-1 (from DCWRRC, 1993a)

Altitude: 61 feet Total Depth: 277 feet

Latitude / Longitude: $38^{\circ} 52^{\prime} 52.00^{\prime \prime} \mathrm{N} / 76^{\circ} 57^{\prime} 27.97^{\prime \prime} \mathrm{W}$

\begin{tabular}{|c|c|c|c|c|}
\hline $\begin{array}{c}\text { Geologic } \\
\text { map } \\
\text { units }\end{array}$ & Description & $\begin{array}{l}\text { Depth to top } \\
\text { of interval } \\
\text { (feet) }\end{array}$ & $\begin{array}{c}\text { Depth to bottom } \\
\text { of interval } \\
\text { (feet) }\end{array}$ & $\begin{array}{c}\text { Thickness } \\
\text { (feet) }\end{array}$ \\
\hline \multirow{8}{*}{ Kpc } & Cuttings: Tan, medium grained sand & 0.0 & 22.0 & 22.0 \\
\hline & No sample & 22.0 & 25.0 & 3.0 \\
\hline & Fine to coarse grained clayey sand & 25.0 & 26.5 & 1.5 \\
\hline & No sample & 26.5 & 30.0 & 3.5 \\
\hline & No sample & 31.5 & 35.0 & 3.5 \\
\hline & Greenish-gray, hard to very stiff clay with trace of sand (damp) & 35.0 & 36.5 & 1.5 \\
\hline & No sample & 36.5 & 40.0 & 3.5 \\
\hline & Greenish-gray clay with trace of sand & 40.0 & 41.5 & 1.5 \\
\hline
\end{tabular}


Appendix 1. Lithologic descriptions.-Continued

Site name: WE Cb 8, MW-1 (from DCWRRC, 1993a)

Altitude: 61 feet Total Depth: 277 feet

Latitude / Longitude: $38^{\circ} 52^{\prime} 52.00^{\prime \prime} \mathrm{N} / 76^{\circ} 57^{\prime} 27.97^{\prime \prime} \mathrm{W}$

\begin{tabular}{|c|c|c|c|c|}
\hline $\begin{array}{l}\text { Geologic } \\
\text { map } \\
\text { units }\end{array}$ & Description & $\begin{array}{l}\text { Depth to top } \\
\text { of interval } \\
\text { (feet) }\end{array}$ & $\begin{array}{l}\text { Depth to bottom } \\
\text { of interval } \\
\text { (feet) }\end{array}$ & $\begin{array}{c}\text { Thickness } \\
\text { (feet) }\end{array}$ \\
\hline & Reddish-brown to brown, hard, clay & 45.0 & 46.5 & 1.5 \\
\hline & No sample & 46.5 & 50.0 & 3.5 \\
\hline & Reddish-brown, dry clay & 50.0 & 51.5 & 1.5 \\
\hline & No sample & 51.5 & 55.0 & 3.5 \\
\hline & Brown, very hard, dry clay & 55.0 & 56.5 & 1.5 \\
\hline & No sample & 56.5 & 60.0 & 3.5 \\
\hline & Brown, hard and stiff, dry clay & 60.0 & 61.5 & 1.5 \\
\hline & No sample & 61.5 & 65.0 & 3.5 \\
\hline & Brown, hard, dry clay & 65.0 & 66.5 & 1.5 \\
\hline & No sample & 66.5 & 70.0 & 3.5 \\
\hline & Reddish-brown, hard, dry clay & 70.0 & 71.5 & 1.5 \\
\hline & No sample & 71.5 & 75.0 & 3.5 \\
\hline & Purple, hard and stiff, dry clay & 75.0 & 76.5 & 1.5 \\
\hline & No sample & 76.5 & 80.0 & 3.5 \\
\hline & Purple, hard, dry clay & 80.0 & 81.5 & 1.5 \\
\hline & No sample & 81.5 & 85.0 & 3.5 \\
\hline & Reddish-brown, hard, dry clay & 85.0 & 86.5 & 1.5 \\
\hline & No sample & 86.5 & 90.0 & 3.5 \\
\hline & Reddish-brown, very hard, dry clay & 90.0 & 91.5 & 1.5 \\
\hline \multirow[t]{20}{*}{ Kpc } & No sample & 91.5 & 95.0 & 3.5 \\
\hline & Reddish-brown, dry clay & 95.0 & 96.5 & 1.5 \\
\hline & No sample & 96.5 & 97.0 & 0.5 \\
\hline & Very hard clay with lenses of sand & 97.0 & 98.5 & 1.5 \\
\hline & No sample & 98.5 & 107.0 & 8.5 \\
\hline & Clay, very hard, brown to gray and purple to reddish-brown & 107.0 & 108.5 & 1.5 \\
\hline & No sample & 108.5 & 117.0 & 8.5 \\
\hline & Reddish clay with some sand lenses & 117.0 & 118.5 & 1.5 \\
\hline & No sample & 118.5 & 127.0 & 8.5 \\
\hline & Reddish-brown, dry clay & 127.0 & 128.5 & 1.5 \\
\hline & No sample & 128.5 & 137.0 & 8.5 \\
\hline & Reddish-brown clay & 137.0 & 138.5 & 1.5 \\
\hline & No sample & 138.5 & 147.0 & 8.5 \\
\hline & Brown, hard, dry clay & 147.0 & 148.5 & 1.5 \\
\hline & No sample & 148.5 & 157.0 & 8.5 \\
\hline & Reddish-brown clay with some gravel and sand lenses (damp) & 157.0 & 158.5 & 1.5 \\
\hline & No sample & 158.5 & 167.0 & 8.5 \\
\hline & Reddish-brown, very hard, dry clay & 167.0 & 168.5 & 1.5 \\
\hline & No sample & 168.5 & 242.0 & 73.5 \\
\hline & Brown, very hard, dry clay & 242.0 & 242.5 & 0.5 \\
\hline
\end{tabular}


Appendix 1. Lithologic descriptions.-Continued

Site name: WE Cb 8, MW-1 (from DCWRRC, 1993a)

Altitude: 61 feet Total Depth: 277 feet

Latitude / Longitude: $38^{\circ} 52^{\prime} 52.00^{\prime \prime} \mathrm{N} / 76^{\circ} 57^{\prime} 27.97^{\prime \prime} \mathrm{W}$

\begin{tabular}{|c|c|c|c|c|}
\hline $\begin{array}{c}\text { Geologic } \\
\text { map } \\
\text { units }\end{array}$ & Description & $\begin{array}{l}\text { Depth to top } \\
\text { of interval } \\
\text { (feet) }\end{array}$ & $\begin{array}{c}\text { Depth to bottom } \\
\text { of interval } \\
\text { (feet) }\end{array}$ & $\begin{array}{l}\text { Thickness } \\
\text { (feet) }\end{array}$ \\
\hline \multirow{3}{*}{ Kps } & $\begin{array}{l}\text { Grayish, coarse grained clayey sand (water intercepted at } 238 \text { feet and rose to } 40 \\
\text { feet below land surface) }\end{array}$ & 243.0 & 250.0 & 7.0 \\
\hline & No sample & 250.0 & 256.0 & 6.0 \\
\hline & Reddish-brown, very dense clayey sand with trace of gravel (wet) & 256.0 & 260.0 & 4.0 \\
\hline
\end{tabular}

Appendix 1. Lithologic descriptions.-Continued

Site name: WE Cb 9, MW-B1 (DCWRRC, 1993b)

Altitude: 45.52 feet Total depth: 19 feet

Latitude / Longitude: $38^{\circ} 53^{\prime} 55.00^{\prime \prime} \mathrm{N} / 76^{\circ} 55^{\prime} 54.97^{\prime \prime} \mathrm{W}$

\begin{tabular}{|c|c|c|c|c|}
\hline $\begin{array}{c}\text { Geologic } \\
\text { map } \\
\text { units }\end{array}$ & Description & $\begin{array}{l}\text { Depth to top } \\
\text { of interval } \\
\text { (feet) }\end{array}$ & $\begin{array}{c}\text { Depth to bottom } \\
\text { of interval } \\
\text { (feet) }\end{array}$ & $\begin{array}{c}\text { Thickness } \\
\text { (feet) }\end{array}$ \\
\hline $\operatorname{dgf}$ & Fill material, clayey, brown & 0.0 & 5.0 & 5.0 \\
\hline \multirow{4}{*}{$\mathrm{Qa}$} & Tan, damp, medium grained clayey sand & 5.0 & 6.5 & 1.5 \\
\hline & No Sample & 6.5 & 10.0 & 3.5 \\
\hline & Brown, wet, medium to coarse grained, gravelly sand & 10.0 & 11.5 & 1.5 \\
\hline & Brown, wet, medium to coarse grained sand with gravels & 15.0 & 16.5 & 1.5 \\
\hline
\end{tabular}

Appendix 1. Lithologic descriptions.-Continued

Site name: WE Cb 11 (described by C. Klohe on March 13, 2006)

Altitude: 59.99 feet Total depth: 24 feet

Latitude / Longitude: $38^{\circ} 53^{\prime} 32.1^{\prime \prime} \mathrm{N} / 76^{\circ} 56^{\prime} 41.2^{\prime \prime} \mathrm{W}$

\begin{tabular}{|c|c|c|c|c|}
\hline $\begin{array}{l}\text { Geologic } \\
\text { map } \\
\text { units }\end{array}$ & Description & $\begin{array}{l}\text { Depth to top } \\
\text { of interval } \\
\text { (feet) }\end{array}$ & $\begin{array}{l}\text { Depth to bottom } \\
\text { of bnterval } \\
\text { (feet) }\end{array}$ & $\begin{array}{c}\text { Thickness } \\
\text { (feet) }\end{array}$ \\
\hline \multirow[b]{2}{*}{ dgf } & $\begin{array}{l}\text { Topsoil and fill. Poorly sorted silt with gravel, rocks, and debris. Lower } 1 \text { foot } \\
\text { is medium brown to orange-brown silty sand with } 0.25 \text {-inch diameter gravels } \\
\text { throughout. ( } 2.5 \text { feet of sample recovery) }\end{array}$ & 0.0 & 4.0 & 4.0 \\
\hline & $\begin{array}{l}\text { Fill. Poorly sorted, medium brown to orange-brown silty sand with poorly sorted } \\
\text { gravels. Bottom } 4 \text { feet is tight, hard, and dry, light orange silt with inclusions } \\
\text { of red, dark gray, and light gray clay chunks as well as pebbles and a 1.5-inch } \\
\text { dark gray angular gravel. ( } 2.5 \text { feet of sample recovery) }\end{array}$ & 4.0 & 8.0 & 4.0 \\
\hline Qa & $\begin{array}{l}\text { Mottled light to medium gray sandy silt with zones of high percent organic mat- } \\
\text { ter (woody material) and poorly sorted gravels and coarse sand. ( } 2.0 \text { feet of } \\
\text { sample recovery). }\end{array}$ & 8.0 & 12.0 & 4.0 \\
\hline
\end{tabular}


Appendix 1. Lithologic descriptions.-Continued

Site name: WE Cb 11 (described by C. Klohe on March 13, 2006)

Altitude: 59.99 feet Total depth: 24 feet

Latitude / Longitude: $38^{\circ} 53^{\prime} 32.1^{\prime \prime} \mathrm{N} / 76^{\circ} 56^{\prime} 41.2^{\prime \prime} \mathrm{W}$

\begin{tabular}{c|cccc}
\hline $\begin{array}{c}\text { Geologic } \\
\text { map } \\
\text { units }\end{array}$ & \multicolumn{1}{c|}{ Description } & $\begin{array}{c}\text { Depth to top } \\
\text { of interval } \\
\text { (feet) }\end{array}$ & $\begin{array}{c}\text { Depth to bottom } \\
\text { of bnterval } \\
\text { (feet) }\end{array}$ & $\begin{array}{c}\text { Thickness } \\
\text { (feet) }\end{array}$ \\
\hline & $\begin{array}{l}\text { Medium brownish-gray silty clay with a high percent of organic matter. Contains } \\
\text { sticks (0.25 inch) to twigs (0.5 inch) and thin layers of organic material } \\
\text { (leaves) throughout. }\end{array}$ & 12.0 & 13.5 & 1.5 \\
Qa & $\begin{array}{l}\text { Very fine, well sorted, light orange, yellow-brown clayey sand. Zone of high } \\
\text { organic content from 14.5 to 15.0 feet with 0.12-inch diameter woody twigs. } \\
\text { Light gray to light tan, clayey, fine-grained sand. Some zones with large pieces } \\
\text { of organic matter, especially near 19.7 feet. Wet. }\end{array}$ & 13.5 & 16.0 & 2.5 \\
\hline $\mathrm{Kpc}$ & $\begin{array}{l}\text { Reddish maroon-brown clay (tight, stiff) with approximately 5 percent light gray } \\
\text { mottling. }\end{array}$ & 20.0 & 20.0 & 4.0 \\
\hline
\end{tabular}

Appendix 1. Lithologic descriptions.-Continued

Site name: WE Cb 12 (described by C. Klohe on August 2, 2005)

Altitude: 60.59 feet Total depth: 81 feet

Latitude / Longitude: $38^{\circ} 53^{\prime} 32.1^{\prime \prime} \mathrm{N} / 76^{\circ} 56^{\prime} 41.2^{\prime \prime} \mathrm{W}$

\begin{tabular}{|c|c|c|c|c|}
\hline $\begin{array}{l}\text { Geologic } \\
\text { map } \\
\text { units }\end{array}$ & Description & $\begin{array}{l}\text { Depth to top } \\
\text { of interval } \\
\text { (feet) }\end{array}$ & $\begin{array}{c}\text { Depth to bottom } \\
\text { of interval } \\
\text { (feet) }\end{array}$ & $\begin{array}{l}\text { Thickness } \\
\text { (feet) }\end{array}$ \\
\hline \multirow{3}{*}{$\operatorname{dgf}$} & Gravel and topsoil. & 0.0 & 0.3 & 0.3 \\
\hline & Tannish-brown silty sand with small gravel. & 0.3 & 3.0 & 2.7 \\
\hline & Brown sandy clay with gravels. & 3.0 & 5.0 & 2.0 \\
\hline \multirow{3}{*}{ Qa } & Brown sandy clay. & 5.0 & 13.0 & 8.0 \\
\hline & Grayish-tan silty sand. & 13.0 & 17.0 & 4.0 \\
\hline & Tan silty sand. & 17.0 & 20.0 & 3.0 \\
\hline \multirow{14}{*}{ Kpc } & Reddish-tan clayey sand. & 20.0 & 22.0 & 2.0 \\
\hline & Red sandy clay. & 22.0 & 40.0 & 18.0 \\
\hline & Little sample return. Possible lithology change at 42 feet. & 40.0 & 42.0 & 2.0 \\
\hline & Tan silty sand. & 42.0 & 43.5 & 1.5 \\
\hline & Grayish-pink clay. (Core sample) & 43.5 & 45.5 & 2.0 \\
\hline & Tan silty sand. Poor sample return (easier drilling from top of interval). & 45.5 & 47.0 & 1.5 \\
\hline & Tan silty sand. Very loose. Wet. & 47.0 & 50.0 & 3.0 \\
\hline & Tan silty sand. & 50.0 & 54.0 & 4.0 \\
\hline & Grayish-pink sandy clay (split-spoon core sample). & 54.0 & 56.0 & 2.0 \\
\hline & Tan silty clay. & 56.0 & 66.5 & 10.5 \\
\hline & Tan silty sand. Loose. Very wet. & 66.5 & 69.0 & 2.5 \\
\hline & Brownish-gray sandy clay to greenish-gray silty clay. (core sample) & 69.0 & 71.0 & 2.0 \\
\hline & Tan silty sand & 71.0 & 72.5 & 1.5 \\
\hline & No sample & 72.5 & 81.0 & 8.5 \\
\hline
\end{tabular}


Appendix 1. Lithologic descriptions.-Continued

Site name: WE Cc 3 (described by C. Klohe on March 2, 2006)

Altitude: 88.70 feet Total depth: 24 feet

Latitude / Longitude: $38^{\circ} 53^{\prime} 27.0^{\prime \prime} \mathrm{N} / 76^{\circ} 54^{\prime} 48.5^{\prime \prime} \mathrm{W}$

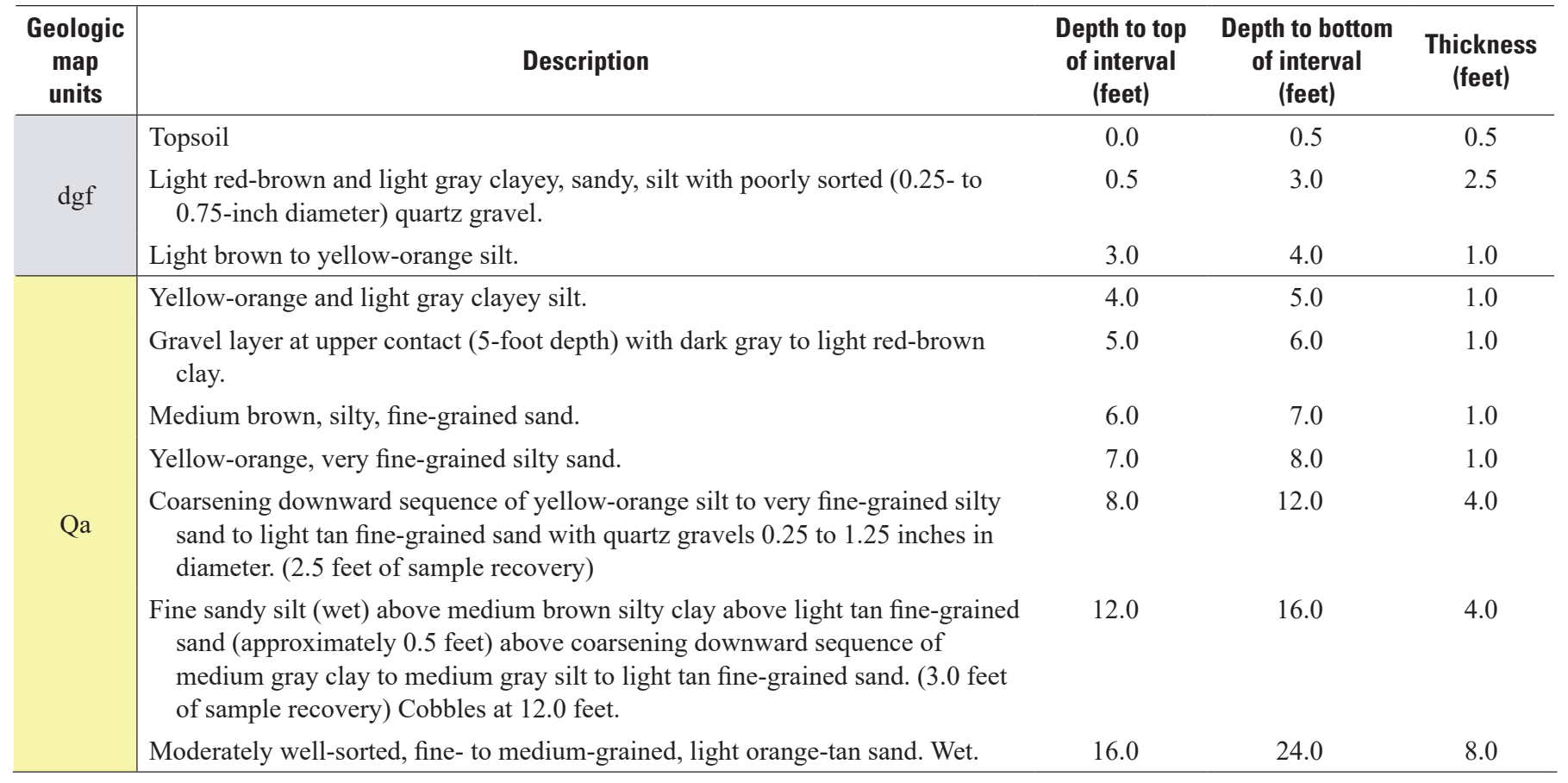

Appendix 1. Lithologic descriptions.-Continued

Site name: WW Bc 8 (described by C. Klohe on March 1, 2006)

Altitude: 123.39 feet Total depth: 32 feet

Latitude / Longitude: $38^{\circ} 55^{\prime} 19.3^{\prime \prime} \mathrm{N} / 77^{\circ} 01^{\prime} 26.9^{\prime \prime} \mathrm{W}$

\begin{tabular}{|c|c|c|c|c|}
\hline $\begin{array}{l}\text { Geologic } \\
\text { map } \\
\text { units }\end{array}$ & Description & $\begin{array}{l}\text { Depth to top } \\
\text { of interval } \\
\text { (feet) }\end{array}$ & $\begin{array}{l}\text { Depth to bottom } \\
\text { of interval } \\
\text { (feet) }\end{array}$ & $\begin{array}{l}\text { Thickness } \\
\text { (feet) }\end{array}$ \\
\hline \multirow{5}{*}{$\operatorname{dgf}$} & $\begin{array}{l}\text { Soil. Medium brown-gray clay. Medium to light tan, fine-grained, poorly sorted, } \\
\text { silty sand, with some clay. ( } 2.0 \text { feet of recovery) }\end{array}$ & 0.0 & 4.0 & 4.0 \\
\hline & $\begin{array}{l}\text { Medium to light tan, fine-grained, poorly sorted, silty sand, some large gravels } \\
\text { and clay. Bottom of interval has a } 2 \text { - to } 4 \text {-inch layer of orange-brown silty } \\
\text { clay layer on top of a 1-inch layer of organic rich soil with large fragments of } \\
\text { broken glass. (1.0 foot of sample recovery) }\end{array}$ & 4.0 & 8.0 & 4.0 \\
\hline & Organic rich, dark brown silt with coarse sand, gravel, and broken glass. & 8.0 & 8.5 & 0.5 \\
\hline & $\begin{array}{l}\text { Medium yellow-brown silt with poorly sorted angular pebbles } 0.25 \text { to } 1.0 \text { inch } \\
\text { in size. }\end{array}$ & 8.5 & 9.5 & 1.0 \\
\hline & $\begin{array}{l}\text { Gray, silty clay mottled with red and brown silty clay. Some pebbles, gravels, } \\
\text { and coarse sands (poorly sorted). }\end{array}$ & 9.5 & 11.0 & 1.5 \\
\hline \multirow{5}{*}{ Qfe } & Light gray clay mottled with red-orange clay. & 11.0 & 16.0 & 5.0 \\
\hline & Light gray silt (transition to no mottling). & 16.0 & 17.0 & 1.0 \\
\hline & Dark gray silty clay. & 17.0 & 20.0 & 3.0 \\
\hline & Light brown silt with some thin layers of silt and fine sand. & 20.0 & 22.0 & 2.0 \\
\hline & Light brown silt transitioning to thinly laminated light gray, organics (black), & 22.0 & 24.0 & 2.0 \\
\hline
\end{tabular}


Appendix 1. Lithologic descriptions.-Continued

Site name: WW Bc 8 (described by C. Klohe on March 1, 2006)

Altitude: 123.39 feet $\quad$ Total depth: 32 feet

Latitude / Longitude: $38^{\circ} 55^{\prime} 19.3^{\prime \prime} \mathrm{N} / 77^{\circ} 01^{\prime} 26.9^{\prime \prime} \mathrm{W}$

\begin{tabular}{|c|c|c|c|c|}
\hline $\begin{array}{l}\text { Geologic } \\
\text { map } \\
\text { units }\end{array}$ & Description & $\begin{array}{l}\text { Depth to top } \\
\text { of interval } \\
\text { (feet) }\end{array}$ & $\begin{array}{l}\text { Depth to bottom } \\
\text { of interval } \\
\text { (feet) }\end{array}$ & $\begin{array}{c}\text { Thickness } \\
\text { (feet) }\end{array}$ \\
\hline \multirow[t]{2}{*}{ Kps } & $\begin{array}{l}\text { Light gray, poorly sorted, fine- to medium- grained silty sand with white (calcar- } \\
\text { eous) silt that leaves light gray to white residue. Some thin layers of cobbles } \\
\text { (0.4- to } 0.8 \text {-inch diameter), iron staining, and organics. }\end{array}$ & 24.0 & 28.0 & 4.0 \\
\hline & $\begin{array}{l}\text { Medium to light gray, poorly sorted, medium-grained, silty sand with white } \\
\text { residue. Interval also includes light gray clay. Poor sample recovery. }\end{array}$ & 28.0 & 32.0 & 4.0 \\
\hline
\end{tabular}

Appendix 1. Lithologic descriptions.-Continued

Site name: WW Bc 9 (described by C. Klohe on March 3, 2006)

Altitude: 133.60 feet Total Depth: 36.0 feet

Latitude / Longitude: $38^{\circ} 55^{\prime} 27.8^{\prime \prime} \mathrm{N} / 77^{\circ} 00^{\prime} 07.7^{\prime \prime} \mathrm{W}$

\begin{tabular}{|c|c|c|c|c|}
\hline $\begin{array}{l}\text { Geologic } \\
\text { map } \\
\text { units }\end{array}$ & Description & $\begin{array}{l}\text { Depth to top } \\
\text { of interval } \\
\text { (feet) }\end{array}$ & $\begin{array}{l}\text { Depth to bottom } \\
\text { of interval } \\
\text { (feet) }\end{array}$ & $\begin{array}{l}\text { Thickness } \\
\text { (feet) }\end{array}$ \\
\hline \multirow[t]{2}{*}{$\operatorname{dgf}$} & $\begin{array}{l}\text { Soil, fill (silt and stones). Zone with lignite, glass, and light colored wood chips. } \\
\text { Bottom of interval contains silt with cobbles. (3.0-feet of sample recovery) }\end{array}$ & 0.0 & 4.0 & 4.0 \\
\hline & No sample recovery. & 4.0 & 8.0 & 4.0 \\
\hline \multirow[b]{3}{*}{$\mathrm{Kpc}$} & $\begin{array}{l}\text { Red-brown clay with organic material and iron nodules. Some nodules are hard } \\
\text { and others are pliable like dark clay. }\end{array}$ & 8.0 & 13.5 & 5.5 \\
\hline & $\begin{array}{l}\text { Transition from reddish clay to medium gray silt with minor traces of organics. } \\
\text { Some thin (less than } 0.25 \text { inches) layers of very fine silty sand. }\end{array}$ & 13.5 & 16.0 & 2.5 \\
\hline & $\begin{array}{l}\text { Medium to dark gray sandy silt. Some zones with a higher percent of very } \\
\text { fine-grained sand. Interval ranges from no mottling to light gray to maroon } \\
\text { mottling. }\end{array}$ & 16.0 & 23.0 & 7.0 \\
\hline \multirow[t]{3}{*}{ Kps } & $\begin{array}{l}\text { Light tan, fine-grained sand with approximately } 5 \text { percent black grains (organic } \\
\text { or dark mineral). Fairly well-sorted. }\end{array}$ & 29.0 & 31.5 & 2.5 \\
\hline & Same as above except increase in silt/clay content. & 31.5 & 32.0 & 0.5 \\
\hline & $\begin{array}{l}\text { Fine sand, medium sand, and gravel. Fining upward. Gravel } 0.12 \text { - to } 0.75 \text {-inch } \\
\text { diameter, angular to rounded. ( } 1.0 \text { foot of sample recovery) }\end{array}$ & 32.0 & 36.0 & 4.0 \\
\hline
\end{tabular}


Appendix 1. Lithologic descriptions.-Continued

Site name: WW Cc 26 (from Hansen, 1968)

Altitude: 65 feet Total depth: 85 feet

Latitude / Longitude: $38^{\circ} 54^{\prime} 10.00^{\prime \prime} \mathrm{N} / 77^{\circ} 01^{\prime} 53.97^{\prime \prime} \mathrm{W}$

\begin{tabular}{|c|c|c|c|c|}
\hline $\begin{array}{c}\text { Geologic } \\
\text { map } \\
\text { units }\end{array}$ & Description & $\begin{array}{l}\text { Depth to top } \\
\text { of interval } \\
\text { (feet) }\end{array}$ & $\begin{array}{l}\text { Depth to bottom } \\
\text { of interval } \\
\text { (feet) }\end{array}$ & $\begin{array}{c}\text { Thickness } \\
\text { (feet) }\end{array}$ \\
\hline \multirow{6}{*}{ Qfe } & Clay, sandy, yellow & 0.0 & 23.0 & 23.0 \\
\hline & Clay, sandy, blue & 23.0 & 41.0 & 18.0 \\
\hline & Sand, medium and gravel & 41.0 & 45.0 & 4.0 \\
\hline & Sand, coarse and gravel & 45.0 & 53.0 & 8.0 \\
\hline & Sand, coarse and gravel & 65.0 & 68.0 & 3.0 \\
\hline & Gravel & 68.0 & 77.0 & 9.0 \\
\hline bedrock & Rock, "rotten"; grading into hard rock & 77.0 & 85.0 & 8.0 \\
\hline
\end{tabular}

Appendix 1. Lithologic descriptions.-Continued

Site name: WW Cc 37 (described by R. Starsoneck on August 11, 2005)

Altitude: 84 feet Total depth: 36 feet

Latitude / Longitude: $38^{\circ} 54^{\prime} 43.41^{\prime \prime} \mathrm{N} / 77^{\circ} 01^{\prime} 34.66^{\prime \prime} \mathrm{W}$

\begin{tabular}{|c|c|c|c|c|}
\hline $\begin{array}{c}\text { Geologic } \\
\text { map } \\
\text { units }\end{array}$ & Description & $\begin{array}{c}\text { Depth to top } \\
\text { of interval } \\
\text { (feet) }\end{array}$ & $\begin{array}{c}\text { Depth to Bottom } \\
\text { of Interval } \\
\text { (feet) }\end{array}$ & $\begin{array}{c}\text { Thickness } \\
\text { (feet) }\end{array}$ \\
\hline dgf & Topsoil and tan silty sand with gravels ( 1.5 to 2.0 feet) & 0 & 2.5 & 2.5 \\
\hline \multirow{6}{*}{ Qt } & Dark gray silty, clayey sand & 2.5 & 4.5 & 2.0 \\
\hline & Greenish-gray clayey sand & 4.5 & 6.0 & 1.5 \\
\hline & Tannish-gray clayey sand and clay & 6.0 & 11.0 & 5.0 \\
\hline & Tan silty clay with gravel & 13.0 & 26.0 & 13.0 \\
\hline & Tan sandy clay & 26.0 & 32.0 & 6.0 \\
\hline & No return from augers & 32.0 & 36.0 & 4.0 \\
\hline
\end{tabular}




\section{References Cited}

A.C. Schultes of Maryland, Inc., [n.d.], National Arboretum wells \#1 \& \#2, job \#2616.

Cooke, C.W., Martin, R.O.R., and Meyer, G., 1952, Geology and water resources of Prince Georges County: State of Maryland Department of Geology, Mines, and Water Resources Bulletin 10, 270 p.

D.C. Water Resources Research Center (DCWRRC), 1993a, Groundwater resource assessment study for the District of Columbia -Well drilling and field operations report for the group A wells: D.C. Water Resources Research Center Report Report No. 126, [variously paged].

D.C. Water Resources Research Center (DCWRRC), 1993b, Groundwater resource assessment for the District of Columbia-Well drilling and field operations report for the group B wells: D.C. Water Resources Research Center Report No. 127, [variously paged].

Hansen, H.J., 1968, Geophysical log cross-section network of the Cretaceous sediments of Southern Maryland: Maryland Geological Survey Report of Investigations No. 7, 46 p.
HSI Geotrans Inc., 1998, Deep production well reportAquatic resource education center, Anacostia Park, Washington, D.C.

Otton, E.G., 1955, Ground-water resources of the Southern Maryland Coastal Plain: Maryland Department of Geology, Mines and Water Resources, Bulletin 15, $347 \mathrm{p}$.

Schnabel Engineering Associates, 1995, Final submittalWater system upgrade, U.S. National Arboretum, Washington, D.C.-Phase II-Hydrologic study irrigation water supply well PW-3 development: BJI JO 90328-01, [variously paged].

Somes, G.C., 2003, Deep aquifer exploration and testing report, Arena Stage, Washington, D.C.: Quality Environmental Solutions, Inc., [variously paged].

Tenbus, F.J., 2003, Lithologic coring in the Lower Anacostia Tidal Watershed, Washington, D.C., July 2002: U.S. Geological Survey Open-File Report 03-318, 62 p. 


\section{Appendix 2. Continuous Groundwater-Level and Temperature Measurements at Sites We Bb 3, We Bb 4, We Cb 5, We Cb 6, We Cb 8, and We Cb 12}

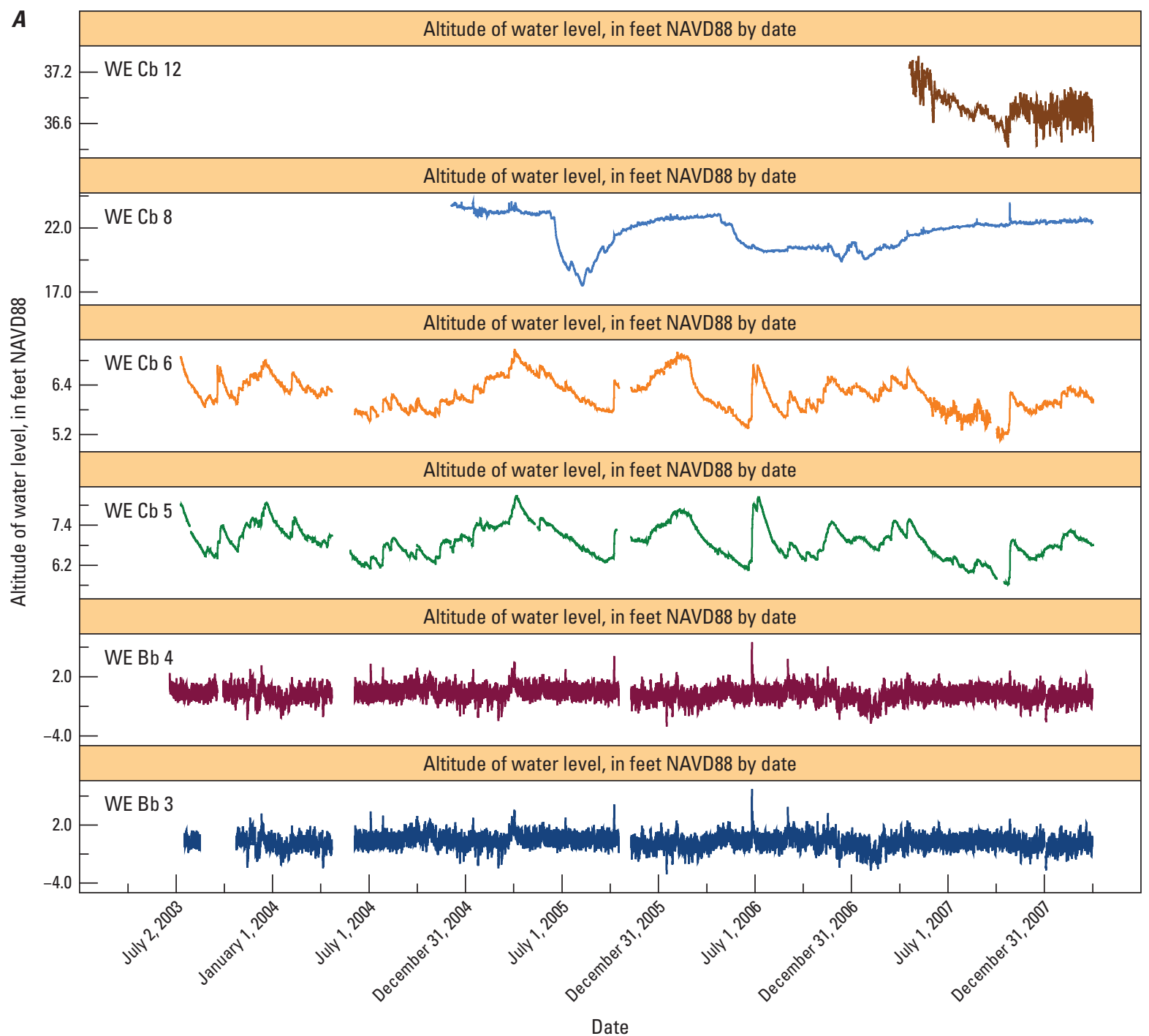

Figure 2.1. $A$, Continuous groundwater level and $B$, temperature measurements at sites $\mathrm{WE} \mathrm{Bb} 3, \mathrm{WE} \mathrm{Bb} 4, \mathrm{WE} \mathrm{Cb} 5, \mathrm{WE} \mathrm{Cb} 6$, WE $\mathrm{Cb}$ 8, and WE Cb 12. Altitudes of water levels are shown in feet relative to North American Vertical Datum of 1988 (NAVD88). 


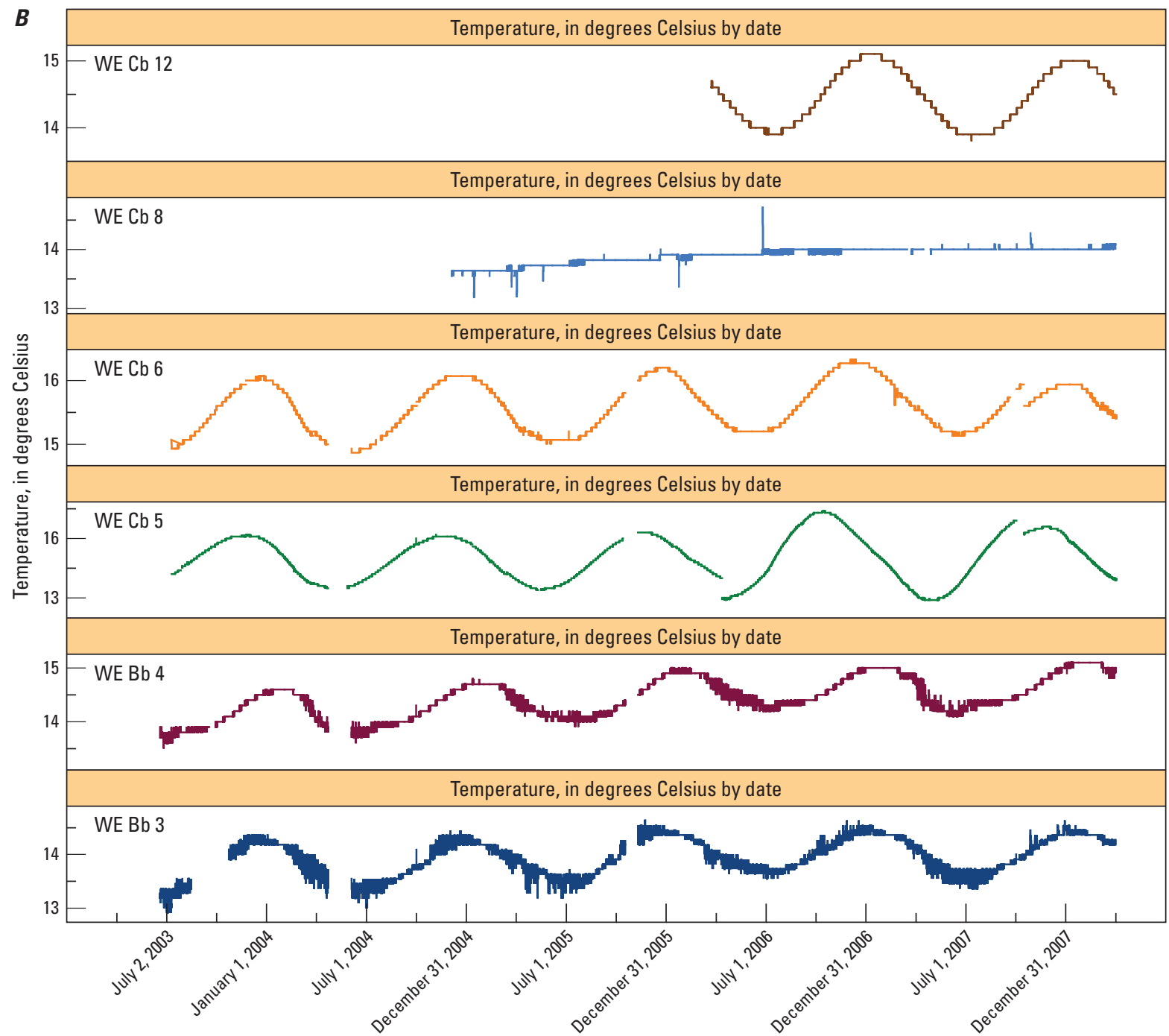

Figure 2.1. $A$, Continuous groundwater level and $B$, temperature measurements at sites $\mathrm{WE} \mathrm{Bb} 3, \mathrm{WE} \mathrm{Bb} 4, \mathrm{WE} \mathrm{Cb} 5$, WE $\mathrm{Cb} 6$, WE Cb 8, and WE Cb 12.-Continued 

For additonal information, contact:

Director, MD-DE-DC Water Science Center

U.S. Geological Survey

5522 Research Park Drive

Baltimore, MD 21228

or visit our website at:

https://www.usgs.gov/centers/md-de-dc-water

Publishing support provided by the U.S. Geological Survey Science Publishing Network, West Trenton and Sacramento Publishing Service Centers 


\section{曾}

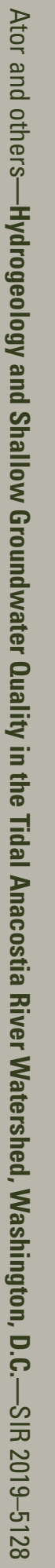

